\title{
Elīna Pūcìte
}

\section{Ar veselību saistītas dzives kvalitātes izmaiṇas pēc nozīmīgas miega artērijas stenozes ārstēšanas}

Promocijas darbs zinātniskā doktora grāda

"zinātnes doktors (Ph.D.)" iegūšanai

Nozare - klīniskā medicina Apakšnozare - neiroloğija

$$
\text { Riga, } 2020
$$




\section{RİGAS STRADINA
UNIVERSITĀTE}

Elīna Pūcīte

ORCID 0000-0003-1792-6398

\section{Ar veselību saistītas dzīves kvalitātes izmaiṇas pēc nozīmīgas miega artērijas stenozes ārstēšanas}

Promocijas darbs zinātniskā doktora grāda

"zinātnes doktors (Ph.D.)" iegūšanai

Nozare - klīniskā medicīna

Apakšnozare - neirologija

Promocijas darba vadītāji:

Dr. med. asociētā profesore Evija Miglāne,

Paula Stradiṇa Klīniskās universitātes slimnīca, R̄̄gas Stradiṇa universitāte, Latvija

Dr. med. profesors Dainis Krieviņš,

Paula Stradiṇa Klīniskās universitātes slimnīca, Latvijas Universitāte

Rīga, 2020 


\begin{abstract}
ANOTĀCIJA
Miega artērijas stenoze ir nozīmīgs išēmiska insulta riska faktors. Aptuveni 10-15\% gadījumu išēmisks insults rodas trombembolijas dēļ no iepriekš asimptomātiskas iekšējās miega artērijas $>50 \%$ stenozes.

Pacientiem pēc pārciesta išēmiska insulta ir ne tikai fiziski funkcionāli ierobežojumi, bet bieži attīstās arī kognitīvi traucējumi un vaskulāra depresija. Tieši pēdējo desmit gadu laikā ir pieaugusi interese par nozīmīgas miega artērijas stenozes izraisītiem "neklasiskajiem" neirologiskajiem simptomiem un to saistību ar dzīves kvalitāti, kā arī revaskularizācijas ietekmi uz šo simptomu attīstību.

Promocijas darbs "Ar veselību saistītas dzīves kvalitātes izmaiņas pēc nozīmīgas miega artērijas stenozes ārstēšanas" veltīts kopējās kognitīvās funkcijas, depresijas simptomu un dzīves kvalitātes izpētei, jo mūsdienīgas nozīmīgas miega artērijas stenozes ārstēšanas mērķis ir ne tikai samazināt išēmiska insulta risku un pagarināt dzīvildzi, bet arī nodrošināt pietiekoši labu ar veselību saistītu dz̄ives kvalitāti ilgtermiṇā kopumā.

Promocijas darba mērķis bija izpētīt kognitīvās funkcijas un ar veselību saistītas dz̄̄ves kvalitātes izmaiņas, depresijas simptomu dinamiku, kā arī precizēt cerebrovaskulāro notikumu un mirstības biežumu pacientiem, kuriem veikta nozīmīgas miega artērijas stenozes revaskularizācija vai pielietota tikai medikamentozā terapija.

Pētniecības darbā tika iekḷauti un analizēti 213 pacienti ar nozīmīgu miega artērijas stenozi, kuriem vai nu veica revaskularizāciju ķirurğiski vai endovaskulāri, vai arī tikai uzsāka optimālu medikamentozo terapiju bez miega artērijas revaskularizācijas. Visiem pacientiem atkārtoti novērtēja kognitīvās funkcijas, depresijas simptomu un ar veselību saistìtas dzīves kvalitātes izmaiņas gada laikā.

Pētījuma rezultāti liecina, ka nozīmīgas miega artērijas stenozes revaskularizācija varētu būt saistîta ar globālās kognitīvās funkcijas uzlabošanos. Savukārt depresijas simptomu izmaiņas pēc nozīmīgas miega artērijas stenozes revaskularizācijas un/vai medikamentozās ārstēšanas netika novērotas. Kopumā pacientiem gadu pēc miega artērijas endarterektomijas dz̄ives kvalitātes saglabājā tādā pašā līmenī kā pirms operācijas. Taču dzīves kvalitātes izmaiņu novērtēšanu pēc miega artērijas stentēšanas un medikamentozās ārstēšanas ietekmēja dažādi klīniskie parametri šajās grupās, tāpēc pārliecinošus secinājumus šobrīd veikt nav iespējams.
\end{abstract}




\section{ANNOTATION}

Carotid artery stenosis is well-known causal risk factor for ischaemic stroke. Approximately $10-15 \%$ of all strokes follow thromboembolism from previously asymptomatic $>50 \%$ internal carotid stenosis.

In addition to functional disability, stroke patients frequently go on to develop cognitive impairment and depression. In the last decade there is growing interest of "nonclassical" neurological symptoms caused by severe carotid stenosis and it's associaton with the health-related quality of life and whether carotid interventions improve the development of these symptoms.

The doctoral thesis "Changes in Health-Related Quality of Life after Carotid Stenosis Treatment" is devoted to investigation of global cognitive function, depressive symptoms and health-related quality of life because the goal of contemporary carotid stenosis management is not only to reduce stroke risk and to extend life expectancy but also to ensure a sufficient high long-term health-related quality of life.

The aim of this study was to assess long-term changes in cognitive function, depressive symptoms and health-related quality of life after carotid stenosis revascularisation and the best medical treatment.

Study involved 213 patients with severe carotid stenosis who underwent assessment of cognitive function, depressive symptoms and health-related quality of life. The assessment was performed before and at 6 and 12 months follow-up periods in patients who had carotid endarterectomy, carotid artery stenting or received the best medical treatment only.

The research results show that revascularisation of severe carotid stenosis may be associated with improvement of global cognitive function. Whereas there was no significant change of depressive symptoms neither after revascularisation, nor after the best medical treatment. In general, carotid endarterectomy maintain preoperative health-related quality of life for at least one year. However, the evaluation of change in health-related quality of life in the carotid stenting and the best medical treatment group was influenced by several clinical parameters. Therefore, conclusive statements were not made at the moment. 


\section{SATURS}

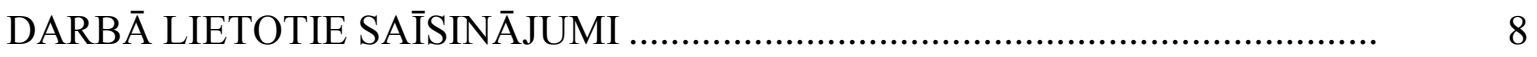

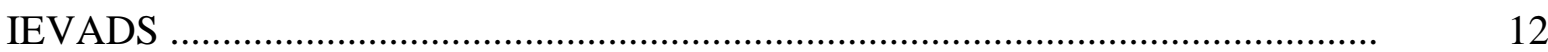

Problēmas aktualitāte.................................................................................. 12

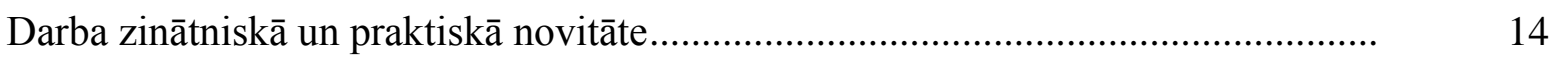

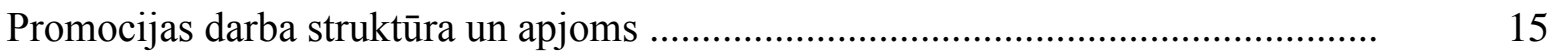

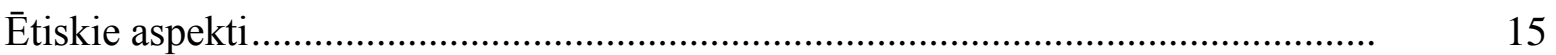

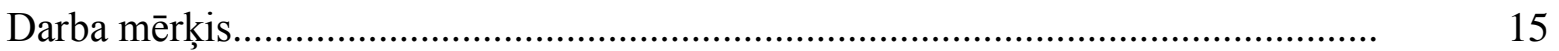

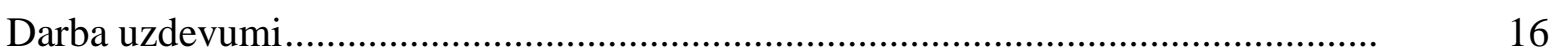

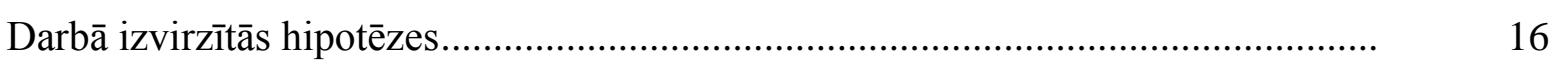

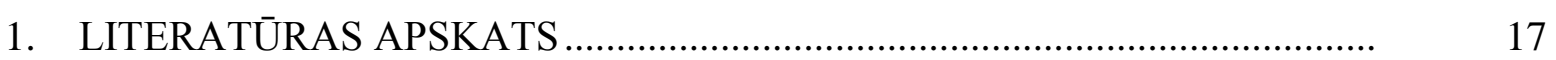

1.1. Nozīmīga miega artērijas stenoze ................................................. 17

1.1.1. Miega artērijas aterosklerozes patoǵenēzes principi ........................ 17

1.1.2. Miega artērijas stenozes pakāpes .................................................... 21

1.1.3. Riska faktori .................................................................................. 23

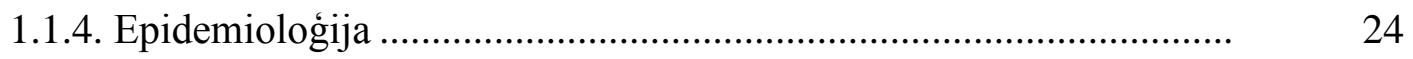

1.1.5. Klīniskā aina ........................................................................ 25

1.1.6. Diagnostika.......................................................................... 26

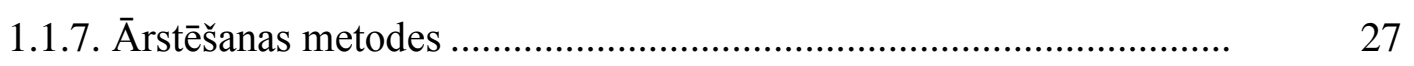

1.1.7.1. Miega artērijas endarterektomija ..................................... 27

1.1.7.2. Miega artērijas perkutāna translumināla angioplastija un stentēšana ....................................................................... 27

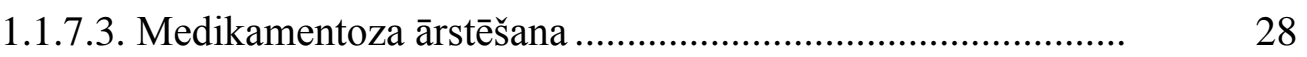

1.1.8. Simptomātiskas miega artērijas stenozes ārstēšana.......................... 28

1.1.8.1. Endarterektomija vai medikamentoza ārstēšana................... 28

1.1.8.2. Endarterektomija vai perkutāna translumināla angioplastija un stentēšana .................................................................. 29

1.1.8.3. Eiropas Asinsvadu ķirurğijas biedrības rekomendācijas ...... $\quad 30$

1.1.9. Asimptomātiskas miega artērijas stenozes ārstēšana ...................... 32

1.1.9.1. Endarterektomija vai medikamentoza ārstēšana.................. 32

1.1.9.2. Endarterektomija vai perkutāna translumināla angioplastija un stentēšana .............................................................. 33

1.1.9.3. Medikamentoza ārstēšana .................................................... 34

1.1.9.4. Eiropas Asinsvadu ķirurgijas biedrības rekomendācijas ...... 34 
1.1.10. Citu vadlīniju rekomendācijas miega artērijas stenozes ārstēšanā..

1.1.10.1. Simptomātiskas miega artērijas ārstēšana.......................... 35

1.1.10.2. Asimptomātiskas miega artērijas ārstēšana ....................... 36

1.2. Kognitīvā funkcija un nozīmīga miega artērijas stenoze .................... 37

1.2.1. Kognitīvo traucējumu patoǵenēzes mehānisms pacientiem ar simptomātisku miega artērijas stenozi ............................................. 38

1.2.2. Kognitīvo traucējumu patoǵenēzes mehānisms pacientiem ar asimptomātisku miega artērijas stenozi............................................ 39

1.3. Depresija un nozīmīga miega artērijas stenoze ................................. 42

1.3.1. Depresijas patoğenēzes mehānisms pacientiem ar simptomātisku miega artērijas stenozi ...........................................................

1.3.2. Depresijas patoǵenēzes mehānisms pacientiem ar asimptomātisku miega artērijas stenozi ............................................................. 44

1.4. Ar veselību saistīta dz̄̄ves kvalitāte un nozīmīga miega artērijas stenoze 45

1.4.1. Simptomātiska miega artērijas stenoze ......................................... 45

1.4.2. Asimptomātiska miega artērijas stenoze ....................................... 46

1.4.3. Dż̄ves kvalitātes izmaiṇas pēc revaskularizācijas ............................ 46

1.4.4. Dz̄̄ves kvalitāte pacientiem ar depresiju, kognitīviem traucējumiem $\quad 47$

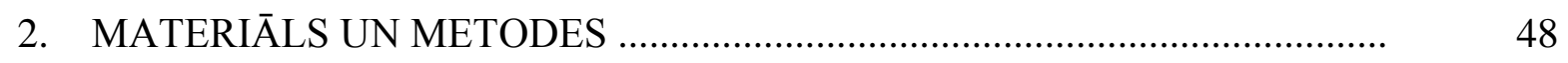

2.1. Pacientu grupas un atlase ............................................................ 48

2.2. Pētījuma norise ........................................................................... 49

2.3. Pêtījumā pielietoto mērinstrumentu raksturojums ............................. 51

2.3.1. Kognitīvās funkcijas novērtēšana................................................. 51

2.3.2. Depresijas simptomu novērtēšana ............................................... 52

2.3.3. Ar veselību saistītās dzīves kvalitātes novērtējums ......................... 54

2.4. Datu statistiskā analīze ................................................................ 56

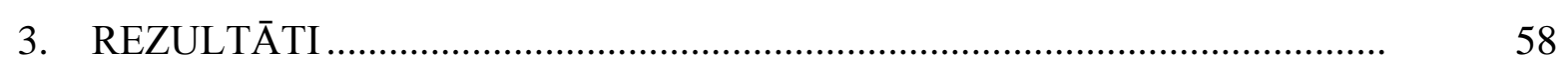

3.1. Primārs un sekundārs nelabvēlīgs iznākums ...................................... 58

3.2. Pacientu demogrāfiskais un klīniskais raksturojums pirms terapijas uzsākšanas ............................................................................... 58

3.3. Pacientu demogrāfiskais un klīniskais raksturojums, kuri neieradās uz

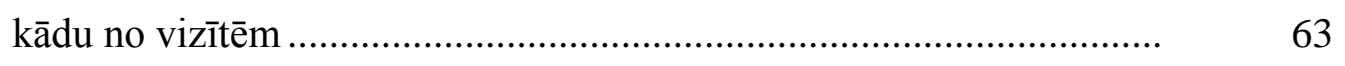

3.4. Kognitīvās funkcijas raksturojums ................................................. 67

3.4.1. Kognitīivās funkcijas raksturojums, uzsākot pētījumu................... 67

3.4.2. Kognitīvās funkcijas izmaiṇas pēc endarterektomijas.................... 69 
3.4.3. Kognitīvās funkcijas izmainas pēc perkutānās transluminālās ...... angioplastijas un stentēšanas.

3.4.4. Kognitīvās funkcijas izmaiņas medikamentozās terapijas grupā ...

3.4.5. Kognitīvās funkcijas izmaiņu atšksirības starp pielietotām ārstēšanas metodēm

3.4.6. Kognitīvās funkcijas izmaiṇu un klīnisko raksturlielumu savstarpējā saistība

3.5. Depresijas simptomu raksturojums ............................................... 75

3.5.1. Depresijas simptomu raksturojums, uzsākot pētījumu ................... 75

3.5.2. Depresijas simptomu biežums pēc endarterektomijas................... 77

3.5.3. Depresijas simptomu biežums pēc perkutānās transluminālās

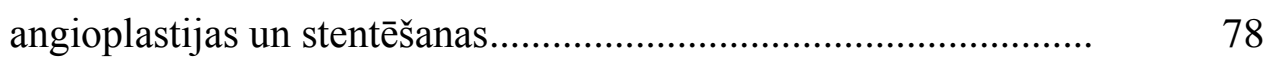

3.5.4. Depresijas simptomu biežums medikamentozās terapijas grupā ... $\quad 80$

3.5.5. Depresijas simptomu analīze pacientiem, kuriem veica miega artērijas endarterektomiju.

3.5.5.1. Pacienti ar depresijas simptomiem pirms endarterektomijas .

3.5.5.2. Pacienti ar depresijas simptomiem pēc endarterektomijas .....

3.6. Ar veselību saistītas dzīves kvalitātes raksturojums .......................... 88

3.6.1. Dz̄ives kvalitātes raksturojums, uzsākot pētījumu ........................ 88

3.6.2. Dzīves kvalitātes saistība ar klīniskiem raksturlielumiem ............. 89

3.6.3. Dz̄ives kvalitātes izmaiṇas pēc endarterektomijas ....................... 94

3.6.4. Dz̄ives kvalitātes izmaiņas pēc perkutānās transluminālās

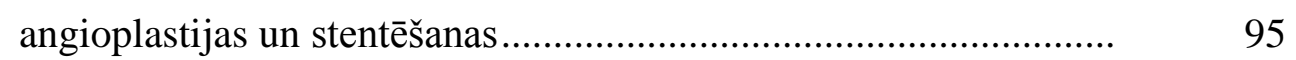

3.6.5. Dz̄ives kvalitātes izmaiṇas medikamentozās terapijas grupā ......... 95

3.6.6. Dz̄ives kvalitātes salīdzinājums starp grupām.............................. 99

3.6.7. Dzīves kvalitātes izmaiṇu saistība ar klīniskiem raksturlielumiem 100

3.6.7.1. Dz̄̄ves kvalitātes izmaiņu saistība ar klīniskiem raksturlielumiem MEA+MT grupā ...................................................... 100

3.6.7.2. Dz̄̄ves kvalitātes izmaiṇu saistība ar klīniskiem raksturlielumiem PTA+MT grupā

3.6.7.3. Dz̄̄ves kvalitātes izmaiṇu saistība ar klīniskiem raksturlielumiem MT grupā.

4. DISKUSIJA.

5. SECINĀJUMI .

6. PRAKTISKĀS REKOMENDĀCIJAS . 
1. pielikums. Ētikas komitejas lēmums

2. pielikums. Datu iegūšanas anketa

3. pielikums. MoCA tests latviešu un krievu valodā

4. pielikums. PHQ-9 tests latviešu un krievu valodā

5. pielikums. SF-36v2 anketa latviešu un krievu valodā

6. pielikums. Dz̄ives kvalitātes izmainas gada laikā pacientiem, kuriem veica miega artērijas endarterektomiju

7. pielikums. Dz̄̄ves kvalitātes izmaiņas gada laikā pacientiem, kuriem veica miega artērijas angioplastiju un stentēšanu.

8. pielikums. Dzīves kvalitātes izmaiṇas gada laikā medikamentozās grupas pacientiem

9. pielikums. Dzīves kvalitātes salīdzinājums starp grupām pēc 6 mēnešiem

10. pielikums. Dz̄ives kvalitātes salīdzinājums starp grupām pēc 12 mēnešiem 


\section{DARBĀ LIETOTIE SAĪSINĀJUMI}

ACAS pētījums Asymptomatic Carotid Artery Stenosis Study

ACC kopējā miega artērija (arteria caroti scommunis)

ACC/AHA Amerikas Kardiologu koledža /Amerikas Sirds biedrība

ACE ārējā miega artērija (arteria carotis externa)

ACI iekšejēā miega artērija (arteria carotis interna)

ACST pētījums Asymptomatic Carotid Surgery Trial

ACT pētījums Asymptomatic Carotid Trial

ACTRIS pētîjums Endarterectomy Combined with Optimal Medical Therapy versus Optimal Medical Therapy Alone in Patients with Asymptomatic Severe Atherosclerotic Carotid Artery Stenosis at High Risk of Ipsilateral Stroke

AD Alcheimera demence

AGMŠ $\quad$ asinsvada gludās muskulatūras šūnas

$\mathrm{AH} \quad$ arteriāla hipertensija

ANOVA vienfaktora dispersijas tests (Analysisofvariance)

AVSDzK ar veselību saistīta dzīves kvalitāte

$\mathrm{BP}$ sāpes (bodily pain)

$\mathrm{CBF}$

cerebrālā asins plūsma (cerebral blood flow)

CD cukura diabēts

CI cerebrāls infarkts

CNS centrālā nervu sistēma

Cramer's V statistiskā efekta lielums - Krāmera V

CREST-2 pētījums Carotid Revascularization and Medical Management for Asymptomatic Carotid Stenosis-2

CTA datortomogrāfijas angiogrāfija

CVR cerebrovaskulārā rezerve

$\mathrm{D}$ veselas jeb normālas iekšējās miega artērijas (ACI) diametrs aiz stenozētās vietas, kur ACI sienas ir paralēlas

DSM-V Diagnostic and Statistical Manual of Mental Disorders, Fifth Edition

$\mathrm{E}$ asinsvada ārējo sieninu diametrs vietā, kur ir vislielākā stenoze

ECST pētījums European Carotid Surgery Trial

EDV beigu diastoliskais ātrums (end-diastolic velocity)

ESC Eiropas Kardiologu biedrība 
statistiskā efekta lielums McNemar testam

GH vispārējais veselības stāvoklis (general health)

GSM pangas stabilitātes novērtěšanas parametrs (gray scale median)

HbA1c glikozētais hemoglobīns

HNS hroniska nieru slimība

HSM hroniska sirds mazspēja

ICH intracerebrāla hematoma

IMT intima media biezums

IQR starpkvartiḷu izkliedes amplitūda (Interquartile range)

Kendall's W statistiskā efekta lielums (Kendall's coefficient of concordance)

KSS koronārā sirds slimība

ĶMI k k kermeña masas indekss

MA mirdzaritmija

MCS psihiskās veselības vispārējais stāvoklis (mental component summary)

MEA miega artērijas endarterektomija

MEA + MT pacientu grupa, kurai veikta miega artērijas endarterektomija

MH psihiskā veselība (mental health)

MI miokarda infarkts

MMSE Mini mentālā stāvokḷa novērtēšanas tests (Mini Mental State Examination)

MoCA Monreālas kognitīvās funkcijas novērtēšanas tests (Montreal Cognitive

Assessment Scale)

MR magnētiskā rezonanse

MRA magnētiskās rezonanses angiogrāfija

mRS modificētā Rankina skala

MT medikamentozās terapijas grupa (pacienti ar nozīmīgu miega artērijas stenozi, kuri paši atteicās no miega artērijas endarterektomijas un/vai plānoja miega artērijas stenozes endovaskulāru ārstēšanu, bet pētījuma norises laikā tā netika veikta no pētījuma neatkarīgu iemeslu dēḷ)

N stenozes šaurākās vietas diametrs

NASCET pētijums North American Symptomatic Carotid Surgery Trial

NIHSS Nacionālā veselības institūta insulta skala (National Instituteof Health Stroke Scale)

NO slāpekḷa oksīids

NYHA New York Heart Association

OR izredžu attiecība (odds ratio) 
PAS perifēro artēriju slimība

PCS fiziskās veselības vispārējais stāvoklis (physical component summary)

PET/CT pozitrona emisijas tomogrāfija un datortomogrāfija

PF fiziskās funkcionēšanas spējas (physical functioning)

PHQ-9 depresijas simptomu noteikšanas skala (Patient Health Questionnaire-9)

post-hoc tests, ko izmanto datu statistiskajā analīzē

PROM anketas, kur pats pacients novērtē savu veselības stāvokli (Patient Reported Outcome Measures)

PSD depresija pēc pārciesta cerebrāla infarkta (Post-Stroke Depression)

PSKUS Paula Stradiña klīniskā universitātes slimnīca

PSV maksimālais sistoliskais plūsmas ātrums (peak systolic velocity)

PTA perkutāna translumināla angioplastija un stentēšana

PTA + MT pacientu grupa, kurai bija veikta miega artērijas perkutāna translumināla angioplastija un stentēšana

PVO Pasaules Veselības organizācija

$r \quad$ statistiskā efekta lielums Wilcoxon rank testam

$\mathrm{r}_{\mathrm{s}} \quad$ Spīrmena (Spearman's) korelācijas koeficients

RCT randomizēts kontrolēts pētījums (Randomised Controled Trial)

RE emocionālais stāvoklis (role limitations due to emotional problems)

RP fiziskā veselības stāvokḷa ietekme uz iesaistīšanos darba un citās ikdienas aktivitātēs (role limitations due to physical problems)

$\mathrm{RR} \quad$ risk ratio

SBP asinsvada sieninas bīdes pretestîba

SD standarta deviācija

SF sociālā funkcija (social functioning)

SF-36 ar veselību saistītas dzīves kvalitātes novērtēšanas anketa (Medical Outcome Survey ShortForm 36)

SF-36v2 ar veselību saistītas dzīves kvalitātes novērtēšanas anketa (Medical Outcome Survey ShortForm 36 version 2)

SVS Asinsvadu ķirurğijas biedrība

TI ticamības intervāls

TIL transitīva išēmiska lēkme

USG dupleksultrasonogrāfija

VACS pētījums Veteran's Affairs Co-operative Study

VD vaskulāra demence 
VaKD vaskulārs kognitīvs deficīts

ViKD viegls kognitīvs deficīts

VT vitalitāte (vitality)

VT/VF vizuāli telpiskā/vadības funkcija

V1 pētījuma pirmā vizīte

V2 pētījuma otrā vizīte

V3 pētījuma trešā vizīte

ZBL zema blīvuma lipoproteīni

$\eta^{2} \quad$ statistiskā efekta lielums - parciālā eta kvadrāts (partial eta squared) 


\section{IEVADS}

\section{Problēmas aktualitāte}

Eiropas Savienībā 2017. gadā bija 511,5 miljoni iedzīvotāju, no kuriem 19,4\% bija vecāki par 65 gadiem (Eurostat, 2018). Uzlabojoties veselības aprūpes kvalitātei, pagarinās ne tikai dzīvildze, bet pieaug arī invalidizējošo saslimšanu radītais slogs kopumā, kā rezultātā palielinās polimorbīdu cilvēku skaits ar dažādām kompleksām saslimšanām (Murray et al., 2017). Viena no biežākajām saslimšanām, kas izraisa funkcionālu nespēju, ir insults. Zināms, ka insulta incidence Eiropā pēdējos gados ir salīdzinoši nemainīga un cieši saistīta ar vecumu. Tāpēc, palielinoties dzīvildzei, pacientu skaits absolūtos skaitḷos, kuri cieš no insulta, nākošajos desmit gados neizbēgami turpinās pieaugt (Béjot et al., 2016). Ir aprēķināts, ka Eiropā 2000. gadā bija 1,1 miljons insulta gadījumu gadā, bet 2025. gadā tie varētu palielināties līdz pat 1,5 miljoniem insulta gadījumiem gadā (Truelsen et al., 2006). Ne tikai funkcionāla nespēja, bet arī kognitīvi traucējumi un depresija ir sastopami 20-30\% pacientu 10 gadu laikā pēc pārciesta insulta (Wolfe et al., 2011). Ņemot to visu vērā, var secināt, ka pieaugs nopietns sociāls un finansiāls slogs sabiedrībai kopumā. Plaši epidemioloǵiski pētījumi ir pierādījuši, ka līdz pat $90 \%$ pacientu insults ir saistīts ar modificējamiem riska faktoriem, kurus varētu novērst (Feigin et al., 2016). Tāpēc joprojām ir nepieciešams uzlabot insulta pirmāros un sekundāros pofilakses pasākumus.

Miega artērijas stenoze ir nozīmīgs išēmiska insulta riska faktors. Aptuveni 10-15\% gadījumu išēmisks insults rodas trombembolijas dēḷ no iepriekš asimptomātiskas iekšējās miega artērijas > 50\% stenozes (Naylor, 2015). Kā iepriekš jau minēts, pacientiem pēc pārciesta išēmiska insulta ir ne tikai fiziski funkcionāli ierobežojumi, bet bieži attīstās arī kognitīvi traucējumi un vaskulāra depresija. Kognitīvu traucējumu prevalence pēc pārciesta insulta variē no 20 līdz pat 80\% (Sun, Tan and Yu, 2014), bet depresija, kas attīstās 5 gadu laikā pēc insulta, ir sastopama $31 \%$ pacientu (Hackett \&Pickles, 2014).

Ja kognitīvu traucējumu un vaskulāras depresijas sastopamība pēc pārciesta cerebrāla infarkta ir zināma, tad pierādījumi un zināšanas par neiropsihologiskiem simptomiem pacientiem ar asimptomātisku nozīmīgu miega artērijas stenozi ir niecīgi un neviennozīmīgi. Par kognitīivu traucējumu patoǵenēzes mehānismu pacientiem ar nozīmīgu miega artērijas stenozi tiek uzskatīta mikroembolija, hipoperfūzija un samazināta cerebrovaskulārā rezerve (Wang, Mei \& Zhang, 2016; Lal, Dux, et al., 2017). Taču infomācija par to, vai un kā miega artērijas stenozes revaskularizācija ietekmē kognitīvo funkciju, vēl joprojām nav pārliecinoša, jo literatūrā pieejamo pētījumu rezultāti ir pretrunīgi (Paraskevas et al., 2014). Turklāt 
aterosklerozes medikamentozā terapija pēdējo 10 gadu laikā ir ievērojami mainījusies, būtiski samazinot ikgadējo cerebrāla infarkta risku asimptomātiskas miega artērijas stenozes pacientiem (Selim \& Molina, 2011). Jāatceras, ka secinājumi par medikamentozi ārstētas asimptomātiskas miega artērijas stenozes ietekmi uz kognitīvo funkciju ir ņemti no randomizēti kontrolētiem pētījumiem, kas veikti vēl pirms 2000. gada, kad aterosklerozes ārstēšanā nelietoja tādu medikamentozo terapiju, kāda tā ir šodien. Tāpēc, ievērojot mūsdienīgu medikamentozo terapiju un smēķēšanas ierobežojumus, šie faktori teorētiski varētu ietekmēt arī neiropsiholoǵisko simptomu sastopamību pacientiem ar nozīmīgu miega artērijas stenozi.

Jautājums par nozīmīgas miega artērijas stenozes saistību ar kognitīviem traucējumiem pirmo reizi ir apskatīts 2017. gada Eiropas Asinsvadu ķirurğijas biedrības izstrādātajās vadlīnijās (Naylor et al., 2018), tomēr skaidri definēts viedoklis un rekomendācijas netika sniegtas. Lai atbildētu uz šo jautājumu, tiek gaidīti rezultāti no diviem randomizēti kontrolētiem CREST-2 un ACTRIS pētījumiem. Viens no pētījumu sekundārajiem mērķiem ir noskaidrot, vai ir vērojama atšķirība starp nozīmīgas asimptomātiskas miega artērijas stenozes ārstēšanas metodēm (intensīvu mūsdienu medikamentozu terapiju un revaskularizāciju), ja tiek izvērtētas kognitīvās funkcijas izmaiṇas ilgtermiņā (Mott, Koroshetz \& Wright, 2017). Pētījuma pirmie dati varētu būt gaidāmi pēc 2020. gada decembra (CREST-2, 2014; ACTRIS, 2018).

Literatūrā ir atrodami atsevišķi ziņojumi par miega artērijas stenozes saistību ar depresiju (Coumans \& McGrail, 2000; Gressier et al., 2011; Mlekusch et al., 2006). N̦emot vērā pieaugošo dažādu hronisku slimību izraisīto slogu visā pasaulē (Iadecola, 2013; Ter Telgte et al., 2018), kā ar̄̄ palielinātu depresijas sastopamību kardiovaskulāru pacientu vidū (Huffman et al., 2013), nepieciešams iegūt informāciju arī par nozīmīgas miega artērijas stenozes saistību ar depresiju. Zināms, ka vaskulāra depresija kā vēlīnas depresijas subtips ir vērā ņemams faktors padzīvojušu cilvēku aprūpē tās klīniskā nozīmīguma un kompleksās patoǵenēzes dēḷ, jo tā sekundāri var vēl vairāk pasliktināt vecāku cilvēku kognitīvo funkciju un attiecīgi arī dzīves kvalitāti kopumā (Aizenstein et al., 2016).

Pacientam, kurš pārcietis cerebrovaskulāru notikumu, ar veselību saistīto dzīves kvalitāti ietekmē ne tikai fiziski funkcionāli ierobežojumi, bet arī kognitīvi traucējumi un depresija. Līdz ar to, būtiska nozīme ir ne tikai kardiovaskulāro riska faktoru kontrolei, bet arī savlaicīgai, pamatotai un efektīvai nozīmīgas miega artērijas stenozes ārstēšanai, jo tā ļauj izvairīties no potenciālas funkcionālas nespējas, samazinot aprūpes slogu ne tikai pašām ǵimenēm un primārās veselības aprūpes sistēmai, bet sabiedrībai kopumā. Var droši apgalvot, ka mūsdienīgas nozīmīgas miega artērijas stenozes ārstēšanas mērķis ir ne tikai samazināt 
išēmiska insulta risku un pagarināt dz̄ivildzi, bet arī nodrošināt pietiekoši labu ar veselību saistītu dzīves kvalitāti ilgtermiņāa (De Smedt, Clays \& De Bacquer, 2016).

\section{Darba zinātniskā novitāte un praktiskā nozīmība}

Tikai pēdējās dekādes laikā ir pieaugusi interese par nozīmīgas miega artērijas stenozes izraisītiem "neklasiskajiem" neirologiskiem simptomiem un to saistību ar dzīves kvalitāti. Jautājums, vai asimptomātiska miega artērijas stenoze tiešām ir asimptomātiska, vēl joprojām ir aktuāls. Iepriekšējie pētījumi lielākoties izvērtēja miega artērijas stenozes revaskularizācijas saistību un ietekmi uz visiem labi zināmiem, klasiskiem fokāliem simptomiem, reti uz "neklasiskajiem" neirologiskiem simptomiem. Turklāt ievērojami mazāk ir pētījumu par miega artērijas stenozes klīniskiem iznākumiem tieši pēc medikamentozās terapijas, turklāt lielākā daļa no tiem ir veikti pirms 2000. gada, kad medikamentozā terapija ievērojami atšķīrās no mūsdienās pielietotās medikamentozās terapijas.

Šì darba zinātnisko novitāti pierāda arī fakts, ka šobrīd norit pirmie randomizēti kontrolētie CREST-2 un ACTRIS pētījumi, kuros viens no mērķiem ir noskaidrot kognitīvās funkcijas izmaiņas pacientiem ar nozīmīgu miega artērijas stenozi gan pēc revaskularizācijas, gan pēc medikamentozās ārstēšanas, bet kuru rezultāti vēl nav zināmi.

Šobrīd mūsu pētījums ir viens no nedaudzajiem, kurā atspoguḷotas kognitīiās funkcijas izmaiņas ilgtermiņā pacientiem ar nozīmīgu miega artērijas stenozi gan pēc revaskularizācijas, gan pēc intensīvas mūsdienīgas medikamentozās ārstēšanas. Tas ir viens no pirmajiem literatūrā pieejamiem pētījumiem, kurā novērtētas depresijas simptomu biežuma izmaiņas pacientiem ar nozīmīgu miega artērijas stenozi gan pēc revaskularizācijas, gan pēc intensīvas mūsdienīgas medikamentozās terapijas ilgtermiṇā. Šis ir pirmais Latvijā veiktais pētījums, kurā novērtēts depresijas simptomu biežums pacientiem ar nozīmīgu miega artērijas stenozi. Mūsu pētījums ir viens no retajiem pašlaik literatūrā pieejamajiem pētījumiem, kurā analizētas ar veselību saistītās dzīves kvalitātes izmaiṇas ilgtermiṇā pēc miega artērijas revaskularizācijas un intensīvas mūsdienīgas medikamentozās terapijas pacientiem ar nozīmīgu miega artērijas stenozi. Jāmin arī ne mazāk svarīgs fakts, ka šī pētījuma rezultātu ietekmē ir izvirzìta jauna hipotēze par depresiju kā iespējamu klīnisko marķieri pacientiem ar nozīmīgu miega artērijas stenozi neatgriezeniska galvas smadzeņu bojājuma raksturošanai, ko nepieciešams pierādīt turpmākos pētījumos.

Promocijas darba rezultāti cerebrovaskulāro saslimšanu nozarē strādājošiem profesionāliem apstiprina nozīmīgas miega artērijas stenozes saistību ar kognitīviem 
traucējumiem un to izmaiņām pēc revaskularizācijas, kas varētu ietekmēt lēmuma pieņemšanu par tās ārstēšanas veidu.

\section{Promocijas darba struktūra un apjoms}

Darbs uzrakstīts latviešu valodā. Tam ir sekojošas daļas: ievads, darba aktualitāte, darba mērķis, darba uzdevumi un hipotēzes, literatūras apskats, materiāls un metodes, rezultāti, diskusija, secinājumi, izmantotās literatūras saraksts. Darba apjoms ir 160 lappuses, tajā ir 16 tabulas, 25 attēli un 10 pielikumi. Literatūras saraksts ietver 243 darbu nosaukumus.

\section{Autora personīgais ieguldījums}

Promocijas darba autore patstāvīgi izveidojusi anketu nepieciešamo datu apkopošanai; ieguvusi promocijas darbā pielietoto anketu un testu aţ̧aujas no institūcijām, kas izstrādājušas šos testus; veikusi katra pacienta telefonisku uzaicinājumu ierasties uz atkārtotām vizītēm, pacientu intervijas un objektīvu neiroloǵisko izmeklēšanu; sistematizējusi, apkopojusi, aprēķinājusi un analizējusi savāktos datus no katras vizìtes.

\section{Ẽtiskie apsekti}

Pētījuma veikšanai tika saņemta Rīgas Stradiņa universitātes Ētikas komitejas atḷauja (1.pielikums). Pētījumā tika iekḷauti tikai tie pacienti, kuri deva rakstisku pacienta informētu piekrišanu.

\section{Darba mērķis}

Šì darba mērķis ir izpētīt kognitīiās funkcijas un ar veselību saistītas dzīves kvalitātes izmaiņas, depresijas simptomu dinamiku, kā arī precizēt cerebrovaskulāro notikumu un mirstības biežumu pacientiem, kuriem veica nozīmīgas miega artērijas stenozes revaskularizāciju vai pielietoja tikai medikamentozo terapiju. 


\section{Darba uzdevumi}

1. Izveidot nozīmīgas miega artērijas stenozes pacientu klīnisko raksturojumu endarterektomijas, endovaskulāras un medikamentozās terapijas grupās.

2. Analizēt primāro un sekundāro nelabvēlīgo notikumu un restenozes biežumu 6 un 12 mēnešus pēc pielietotās ārstēšanas metodes.

3. Izvērtēt globālo kognitīvo funkciju un to dinamiku 6 un 12 mēnešus pēc pielietotās ārstēšanas metodes katrā no pētāmām grupām.

4. Izvērtēt depresijas simptomu biežumu un to dinamiku 6 un 12 mēnešus pēc pielietotās ārstēšanas metodes katrā no pētāmām grupām.

5. Izvērtēt ar veselību saistītās dzīves kvalitātes izmaiņas 6 un 12 mēnešus pēc pielietotās ārstēšanas metodes katrā no pētāmām grupām.

6. Salīdzināt kognitīvās funkcijas, depresijas simptomu, dzīves kvalitātes izmaiņas un neirologisko notikumu un restenožu biežumu starp pētījuma grupām pēc 6 un 12 mēnešiem.

\section{Darbā izvirzītās hipotēzes}

1. Pacientiem pēc miega artērijas stenozes revaskularizācijas mazinās kognitīivie traucējumi un depresijas simptomu biežums, kā arī uzlabojas dzīves kvalitāte, salīdzinot ar objektīvo stāvokli pirms revaskularizācijas.

2. Pacientiem pēc miega artērijas revaskularizācijas retāk sastop kognitīvus traucējumus, depresijas simptomus un viņiem ir būtiski labāki ar veselību saistīti dzīves kvalitātes rādītāji, salīdzinājumā ar pacientiem, kuriem revaskularizācija nebija veikta. 


\section{LITERATŪRAS APSKATS}

\subsection{Nozīmīga miega artērijas stenoze}

\subsubsection{Miega artērijas aterosklerozes patoğenēzes principi}

Ekstrakraniālo cerebrovaskulāro slimību grupa ietver dažādas saslimšanas, kas skar galvas un kakla asinsvadus. Tās ietekmē galvas smadzeņu asins apgādi un var būt iemesls cerebrālam infarktam (CI) vai transitīvai išēmiskai lēkmei (TIL). Atšķirībā no citām ekstrakraniālām cerebrovaskulārām arteriālām saslimšanām, tādām kā fibromuskulāra displāzija, cistiska mediāla nekroze, arterīts vai disekcija, ateroskleroze ir viens no biežākajiem iemesliem, kas izraisa miega artērijas sašaurinājumu jeb stenozi (Brott et al., 2011).

Ateroskleroze ir hroniska sistēmiska iekaisīga slimība, kas rodas endotēlija bojājuma un lip̄ìdu oksidācijas rezultātā. To raksturo lip̄idu un saistaudu kompleksa veidošanās asinsvada sienā kopā ar izmainītām gludās muskulatūras un iekaisuma šūnām, kas veido pangu un progresējošu asinsvada lūmena sašaurināšanos (Bourque \& Kramer, 2011). Ateroskleroze skar liela un vidēja izmēra elastīgā tipa un muskuḷtipa artēriju iekšējo slāni, tādējādi izraisot išēmiskas izmaiṇas apasiņotajos orgānos (Ross, 1999).

Aterosklerozes patoǵenēzes pamatā ir hronisks, sarežğìts, iekaisīgs process, kurā ir iesaistīti dažādi celulārie, metabolie un iekaisīgie faktori. Aterosklerozes patoǵenēzes pirmais solis ir asinsvada endotēlija disfunkcija, kas rodas kā atbildes reakcija uz tādiem faktoriem kā hiperholesterinēmija, oksidēti zema blīvuma lipoproteīni un to produkti, brīvie radikāḷi, kas rodas smēķēšanas rezultātā, arteriāla hipertensija, cukura diabēts, ǵenētiski faktori, paaugstināts homocisteīna līmenis plasmā, hroniskas infekcijas un šo faktoru kombinācijas (Ross, 1999; Gimbrone \& García-Cardeña, 2013). Saglabāts, vesels endotēlijs palīdz nodrošināt asinsvada homeostāzi, sekretējot gan vazodilatatoru - slāpekḷa oksīdu (NO), gan vazokonstriktorus - endotelīnu un angiotensīnu II. Vazodilatatoru biopieejamības samazināšanās un, attiecīgi vazokonstriktoru palielināšanās, veicina apstākḷus, lai veidotos tromboze un ateroskleroze (Loscalzo, 2001). Izmaiņas NO sekrēcijā un vazodilatācijasvazokonstrikcijas reakcijās ir vienas no pirmajām pazīmēm, bet nevienīgās, ko novēro pie asinsvadu patolog̣ijām, bieži pat pirms paša aterosklerotiskā bojājuma attīstīšanās (Wang \& Butany, 2017).

Cits nozīmīgs endotēlija disfunkcijas rezultāts ir iekaisuma reakcijas aktivācija (Ross, 1999). Endotēlija šūnas ne tikai palielina caurlaid̄̄bu lipoproteīniem un veicina to oksidāciju, 
bet arī piedalās leikocītu rekrutēšanā, adhēzijā un asinsvada sieniņas diapedēzē, producējot hemokīnus, citokīnus un intracelulāros transkripcijas faktorus. NO normā darbojas pretēji katram no iepriekš minētajiem iekaisuma procesiem, tāpēc samazināta tā biopieejamība ir veicinošs apstāklis, lai veidotos ateroskleroze. Turklāt samazināts NO daudzums uztur patologiskā procesa progresēšanu, izmaina ekstracelulārās matrices metabolismu, palielina asinsvada gludās muskulatūras šūnu proliferāciju un migrāciju, palielina trombocītu aktivāciju un izmaina hemostāzes-trombotisko homeostāzi, kas veicina trombozes veidošanos (Faxon et al., 2004), (Gimbrone \& García-Cardeña, 2013).

Ir zināms, ka bez šiem bioķīmiskajiem stimuliem arī biomehāniskiem spēkiem, ko rada asins plūsma, ir ietekme uz endotēlija šūnu struktūru un funkcijām (Gimbrone \& GarcíaCardeña, 2013). Biomehānisko spēku lomu, bet ne kā tiešu iemeslu aterosklerozes veidošanās procesā, pierāda fakts, ka aterosklerozes radītie bojājumi veidojas raksturīgās asinsvada sieniņas vietās. Šīs vietas ir asinsvadu sazarošanās rajoni, kur asins plūsmas turbulence un plūsmas spiediens ir visaugstākais (Dhawan et al., 2010), kā arī vietas, kur asinsvada sieniņai ir liels izliekums, piemēram, miega artērijas sīnusa rajonā (VanderLaan, Reardon \& Getz, 2004). Lamināra asinsplūsma veicina NO, COX-2 un KLF2 (Kruppel-like factor 2) veidošanos, kam ir aizsargājoša ietekme uz aterosklerozes attīstību, jo samazina iekaisuma reakciju. Turpretī endotēlijs, kas ir pakḷauts turbulentai asins plūsmai, aktivē proinflammatoru NF-kappa B un pārveido citoskeleta proteīnus, kas savukārt veicina monocītu iekļūšanu asinsvada sieniņā caur endotēlija šūnu savienojumiem, kur monocīti diferencējas par makrofāgiem (Tabas, García-Cardeña \& Owens, 2015). Pulsējošai asins plūsmai caur sazarotu artēriju baseinu ir dažāda veida hemodinamikas spēku ietekme - asinsvada sieniņas bīdes pretestības izraisīts spiediens, hidrostātisks spiediens un ciklisks iestiepums (pulsācijas), kas arī var ietekmēt asinsvada sieniņas bioloǵiju. Tā kā asinsvada sieniņas tunica intima šūnas ir tiešā kontaktā ar asinīm un asins plūsmu, endotēlijs ir pakḷauts tiešam berzes spēkam - asinsvada sieniņas bīdes pretestībai (SBP), ko rada asinis kā viskozs šķidrums (Dhawan et al., 2010; Gimbrone \& García-Cardeña, 2013). Domājams, ka zemas asinsvada sieniņas bīdes pretestības rezultātā tiek veicināta aterogēno substanču transportēšana, kas savukārt veicina aterosklerozes veidošanos (Zarins et al., 1983; Dhawan et al., 2010), (1.1. attēls). 


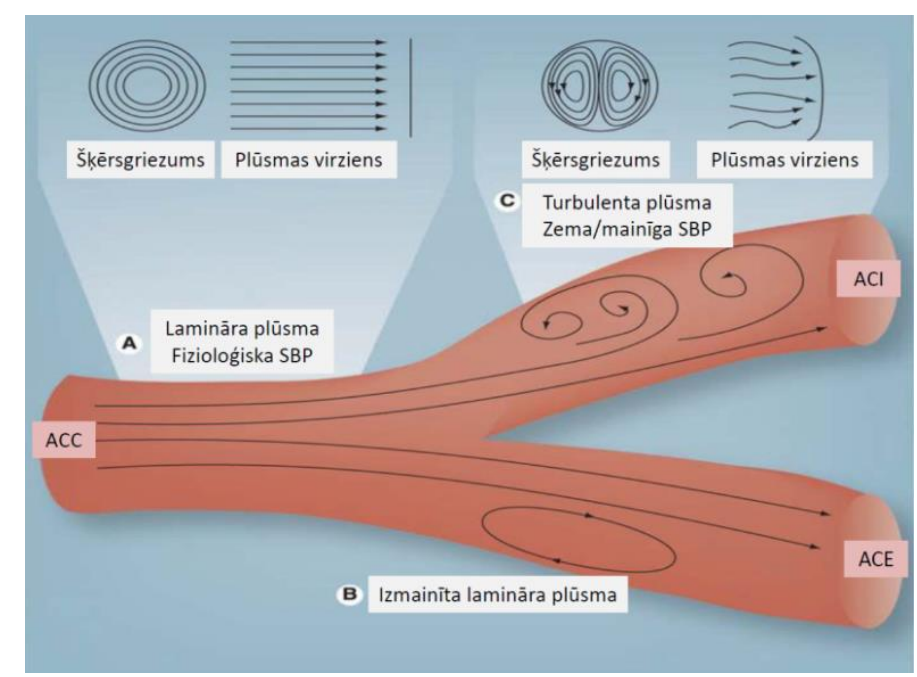

\section{1. attēls. Dažādu asins plūsmu shematisks attēlojums miega artērijas bifurkācijas rajonā}

(Dhawan et al., 2010)

A - lamināra plūsma, kur šķidruma slāṇi pārvietojas plūdlīniju veidā. B - izmainīta lamināra plūsma, kur šķidruma slānni sadalās un plūst pretējā virzienā un tad atkal pievienojas galvenai plūsmai, kas plūst uz priekšu. C - turbulenta plūsma, kur pastāvīgi variè šķidruma âtrums, bet plūsmas virziens kopumā ir vērsts uz priekšu ar samazinātu ātruma profilu.

ACC - kopējā miega artērija; ACI - iekšējā miega artēija; ACE - ārējā miega artērija; SBP - asinsvada sieninas bīdes pretestība.

Miega artērijas ateroskleroze galvenokārt ir lokalizēta kopējā miega artērijā - tās distālajā un bifurkācijas rajonā un iekšējās miega artērijas proksimālajā daḷā (dažos pirmajos centimetros). Retāk tiek skarti kopējās miega artērijas (ACC) proksimālie un iekšējās miega artērijas (ACI) ekstrakraniālie distālie segmenti. (Fisher, Gore, Okabe, 1965) Tomēr, nereti aterosklerozi var arī vērot ACC sākuma daļā un ACI sifona un kavernozajās daļā intrakraniāli (1.2. attēls). Šāds nevienmērīgs un lokāls aterosklerozes izvietojums norāda, ka asins plūsmas pieliktajam spēkam pret asinsvada sieninu un sieniņas ievainojamībai arī ir nozīmīga loma atersoklerozes patoğenēzē (Bonati \& Brown, 2015).

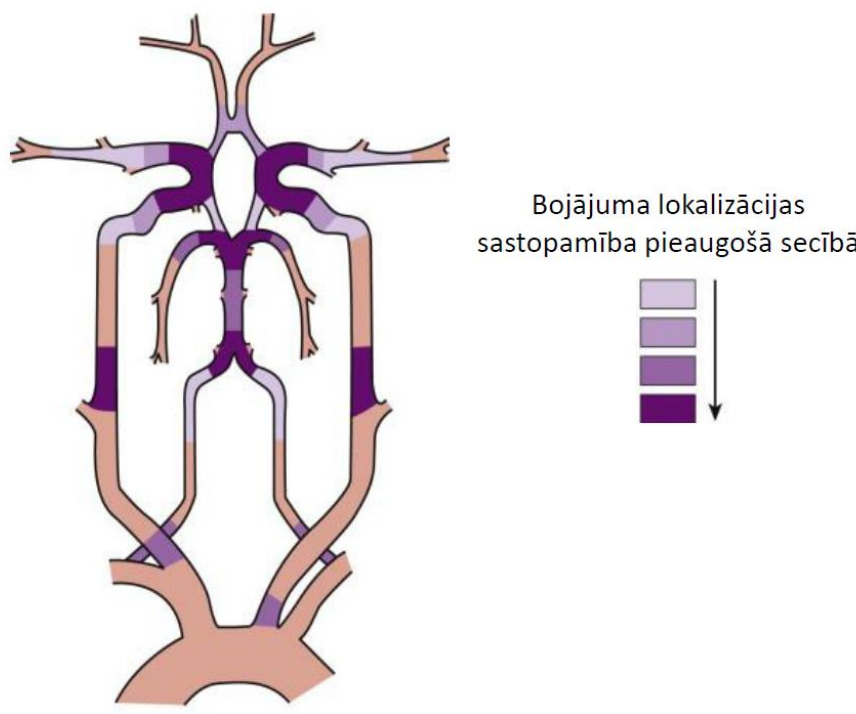

1.2. attēls. Aterosklerotisku bojājumu lokalizācijas sastopamība priekšējā un mugurējā cirkulācijas baseinā (Bonati \& Brown, 2015) 
Ne tikai hiperholesterinēmija ir viens no galvenajiem aterosklerozes riska faktoriem, bet ar̄̄ zema blīvuma lipoproteīni (ZBL), neapšaubāmi, tieši izraisa kardiovaskulāru aterosklerozi (Ference et al., 2017). ZBL, kuri var tikt modificēti oksidācijas, glikēšanas, agregācijas rezultātā vai iekḷauti proteoglikānu vai imūnajos kompleksos, ir būtiska loma endotēlija un gludo muskuḷu šūnu bojājuma veicināšanā aterosklerozes patoǵenēzes procesā (Ross, 1999). Oksidētie ZBL inducē vairākus ateroǵenēzes procesus, tai skaitā proateroǵenētisko gēnu transkripciju, matrices metaloproteināzes un audu faktora produkciju, kavē endotēlija NO produkciju, veicina asinsvadu gludās muskulatūras šūnu apoptozi (Kita et al., 2001). Oksidēto ZBL akumulācija asinsvada sieniṇā izraisa endotēlija disfunkciju, kas savukārt izdala dažādas adhēzijas molekulas, veicinot $\mathrm{T}$ šūnu, monocītu migrāciju asinsvada sieniṇā subendoteliāli. Aktivētie leikocīti izdala dažādus enzīmus un peptīdus, augšanas faktorus un citokīnus, kas degradē matrices proteīnus un stimulē asinsvada gludās muskulatūras šūnas, endotēlija šūnas un makrofāgus. (Faxon et al., 2004) Makrofāgi veidojas no monocītiem makrofāgu kolonijas stimulējošā faktora ietekmē. Savukārt makrofāgi fagocitē oksidētos ZBL, tādējādi pārvēršoties par putu šūnām (foamcells). Makrofāgi ne tikai pasīvi sevī uzkrāj ZBL, bet arī, sekretējot citokīnu, veicina $\mathrm{T}$ limfocītu aktivāciju un papildus makrofāgu migrāciju. (McLaren et al., 2011) Turklāt makfrofāgi producē matrices metaloproteināzi, kas var remodelēt ekstracelulāro matrici un vājināt izveidojušās aterosklerotiskās pangas stabilitāti (Tabas, García-Cardeña \& Owens, 2015; Sakakura et al., 2013).

Aktivējot asinsvada gludās muskulatūras šūnas (AGMŠ), tās arī piedalās aterosklerozes patoǵenēzē. Normā tunica intima slānī ir tikai dažas AGMŠ, bet aterosklerotiskā pangā - daudz. Aterosklerozes patoǵenēzes procesā dažādu citokīnu un augšanas faktoru aktivācijas rezultātā tiek aktivētas AGMŠ, ar kurām notiek fenotipiskas izmaiņas - tās sāk migrēt uz neointima un kḷūst par vienu no galvenajām šūnām, kas sekretē ekstracelulārās matrices proteīnus, tādējādi palielinot aterosklerozes radītās pangas apjomu. (Bennett, Sinha \& Owens, 2016) Aterosklerotiskās pangas celulārie komponenti savstarpēji mijiedarbojas un aktīvi modificēe ekstracelulāro matrici. Piemēram, pretēji AGMŠ, makrofāgi producē matrices metaloproteināzi, kas degradē un remodelē ekstracelulāro matrici. Tāpēc palielināts šo enzīmu līmenis padara fibrozo kapsulu plānāku un attiecīgi palielina aterosklerotiskās pangas ruptūras risku. (Ketelhuth \& Bäck, 2011) Turklāt AGMŠ apoptoze un nekroze kopā ar putu šūnām piedalās nekrotiskās serdes veidošanā, tādējādi mazinot pangas stabilitāti. Destruētās AGMŠ veicina iekaisuma faktoru veidošanos, kas savukārt vēl vairāk stimulē iekaisuma procesu un endotēlija disfunkciju. (Bennett, Sinha \& Owens, 2016) Ja notiek pangas ruptūra, trombocīti saskaras ar subendoteliālo kolagēnu, von Villebranda 
faktoru un lokāliem agonistiem, piemēram, adenozīnadifosfātu. Aktivētie trombocīti saistās ar fibrinogēnu un sekretē dažādus prokoagulācijas un proiekaisuma faktorus, kas veicina leikocītu aktivāciju un fibrīna veidošanos. Uz rupturētas pangas var izveidoties lokāls trombs, kas savukārt embolijas veidā var distāli okludēt asinsvadu un klīniski izpausties kā TIL, amaurosis fugax vai kā išēmisks insults. (Bonati \& Brown, 2015) Turklāt aterosklerozes procesam kḷūstot kompleksākam, bez iekaisuma reakcijas var vērot arī tunica intima mineralizāciju jeb kalcifikāciju. To regulē enzīmi, kas ir iesaistīt fizioloǵiskā un patoloǵiskā mineralizācijāa jo asinsvada sieniņas šūnas var diferencēties par osteohondrogēnām šūnām. Tāpēc aterosklerotiskās pangas kalcifikācijai un matrices remodulācijai var būt gan patolog̣iska, gan protektīva nozīme. Tas ir, kalcifikācija samazina asinsvada sieniņas elasticitāti, tādējādi veicinot stenozes veidošanos, bet tā var stiprināt pangu un samazināt ruptūras risku (Boström, 2016).

\subsubsection{Miega artērijas stenozes pakāpes}

Kopš deviņdesmito gadu sākuma, kad tika publicēti NASCET (North American Symptomatic Carotid Surgery Trial) pētījuma dati, vēl joprojām visā pasaulē plaši izmanto šajā pētījumā pielietotos miega artērijas stenozes pakāpes noteikšanas un klasifikācijas kritērijus. Par vidējas pakāpes stenozi uzskata miega artērijas lūmena sašaurinājumu no 30-69\%. Vidējas pakāpes stenozi var iedalīt sīkāk: ja sašaurinājums ir $<50 \%$, tad tā ir viegli vidējas pakāpes (low moderate) stenoze, bet ja no 50-69\%, tad miega artērijas stenoze tiek definēta kā izteikti vidējas (high moderate) pakāpes stenoze. Savukārt ja stenoze ir no 70-99\%, tad tā tiek uzskatīta par augstas pakāpes jeb nozīmīgu miega artērijas stenozi. (North American Symptomatic Carotid Endarterectomy Trial Colaborators, 1991; Barnett et al., 1998)

Ir dažādas metodes un veidi, kā mērīt miega artērijas stenozes pakāpi. Veicot miega artērijas intraarteriālu angiogrāfiju, NASCET pētījumā izmantoja sekojošu formulu: stenoze $\%=(1-\mathrm{N} / \mathrm{D})$ x 100, kur N - stenozes šaurākās vietas diametrs, bet D - veselas jeb normālas iekšējās miega artērijas (ACI) diametrs aiz stenozētās vietas, kur ACI sienas ir paralēlas viena otrai (1.3. attēls). Savukārt ECST (European Carotid Surgery Trial) pētījumā stenoze procentos tika aprēķināta sekojoši: stenoze \% $\%(1-\mathrm{N} / \mathrm{E})$ x 100 , kur N - stenozes šaurākās vietas diametrs, bet E - asinsvada ārējo sieniņu esošais diametrs vietā, kur stenoze ir vislielākā (Rothwell et al., 2003), (1.3. attēls). Abas šīs formulas arī var izmantot miega artērijas stenozes pakāpes noteikšanai, ja veic datortomogrāfijas angiogrāfiju (CTA). 


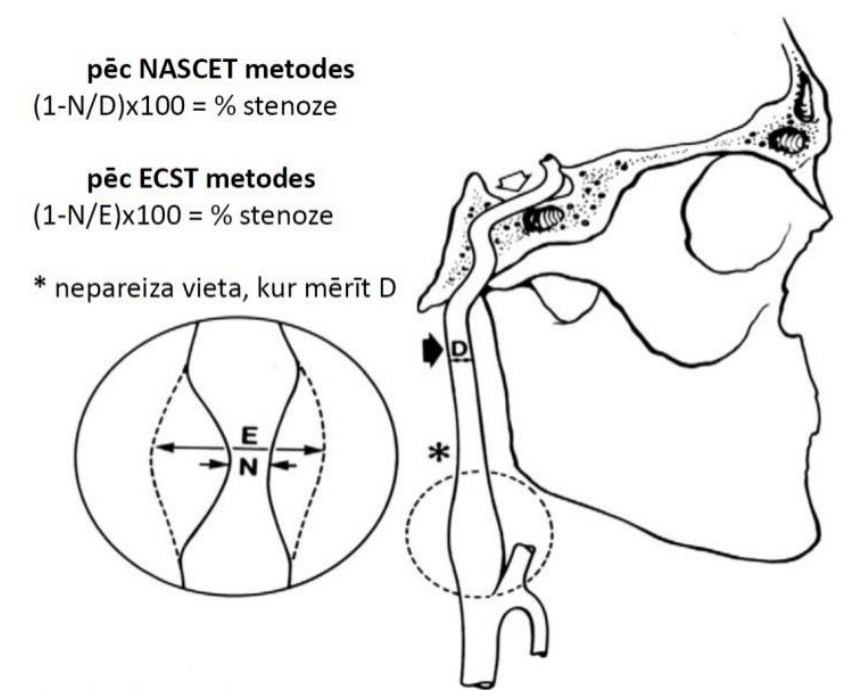

\section{3. attēls. Ekstrakraniālās miega artērijas stenozes pakāpes noteikšana pēc arteriālās angiogrammas attēliem (Rothwell et al., 2003)}

Tā kā abi pêtījumi pierādīja, ka ieguvums no endarterektomijas pacientiem ar simptomātisku miega artērijas stenozi ir atkarīgs no pakāpes lieluma, tad būtiski ir izvēlēties precīzu un uzticamu metodi tās aprēksināšanai. NASCET un ECST pētījuma metaanalīzē atkārtoti tika analizētas šajos pētījumos izmantotās intraarteriālās angiogrammas un pēc tam savstarpēji salīdzinātas pielietotās stenožu pakāpes noteikšanas metodes. Šajos jaunajos aprēķinos ieguva atšķirīgus salīdzinošos miega artēriju stenožu pakāpju mērījumus. Piemēram, NASCET pētījumā 50\% un 70\% stenoze pēc ECST formulas bija attiecīgi $70 \%$ un 82\% (Rothwell et al., 1994). Tāpēc, lai izvairītos no pretrunīgiem datiem, lietojot dažādas stenozes aprēķināšanas metodes, NASCET metode tiek rekomendēta kā standarta metode (Rothwell et al., 2003) gan Eiropas Kardiologu biedrības, gan Amerikas Insulta asociācijas vadlīnijās, bet tikai ar vienu izṇēmumu. Gadījumā, kad vērojama liela apjoma aterosklerotiska panga dilatētā bulbus carotis apvidū, iesaka izmantot ECST stenozes aprēķināšanas formulu, jo šajā gadījumā reziduālais lūmena diametrs var būt tikai nedaudz mazāks kā ACI distālā daļa (Brott et al., 2011; Naylor et al., 2018).

Miega artērijas stenozes pakāpi ir iespējams noteikt arī ar dupleksultrasonogrāfijas metodi. Lai definētu miega artērijas stenozes pakāpi, ir jānosaka maksimālais sistoliskais plūsmas ātrums (peak systolic velocity (PSV)) bifurkācijas rajonā un iekšējā miega artērijāa kāa arī beigu diastoliskais plūsmas ātrums (end-diastolicvelocity (EDV)) kopējās miega artērijas distālajā daḷā un ACI, un ACI maksimālā sistoliskā un ACC beigu diastoliskā plūsmas ātruma attiecība. Šie parametri ir samēroti ar miega artērijas stenožu pakāpēm pēc NASCET kritērijiem (1.1. tabula), (Oateset al., 2009). 
Kritēriji miega artērijas stenozes pakāpes noteikšanai, izmantojot dupleksultrasonogrāfiju

\begin{tabular}{|c|c|c|c|}
\hline $\begin{array}{l}\text { Stenozes pakāpe \% } \\
\text { (pēc NASCET) }\end{array}$ & $\begin{array}{c}\text { Iekšējās miega } \\
\text { artērijas PSV } \\
\text { cm/sec }\end{array}$ & $\begin{array}{c}\text { PSV attiecība } \\
\text { ACI }_{P S v} / \text { ACC }_{\text {PSv }}\end{array}$ & $\begin{array}{l}\text { St. Mary's attiecība } \\
\text { ACIPSV/ACC }_{\text {EDV }}\end{array}$ \\
\hline$<50$ & $<125$ & $<2$ & $<8$ \\
\hline $50-59$ & $>125$ & $2-4$ & $8-10$ \\
\hline $60-69$ & & & $11-13$ \\
\hline $70-79$ & $>230$ & $>4$ & $14-21$ \\
\hline $80-89$ & & & $22-29$ \\
\hline $\begin{array}{l}>90 \text {, bet mazāk kā } \\
\text { suboklūzija }\end{array}$ & $>400$ & $>5$ & $>30$ \\
\hline Suboklūzija & $\begin{array}{l}\text { augsts, zems-līnijas } \\
\text { veida plūsma }\end{array}$ & dažāâds & dažāds \\
\hline Oklūzija & plūsma nav & nav piemērojams & nav piemērojams \\
\hline
\end{tabular}

\subsubsection{Riska faktori}

Vairāki klīniskie pētījumi pēdējos 20 gados izmantoja miega artērijas stenozes pakāpi kā mērījumu, lai stratificētu CI risku. Taču, uzlabojoties attēldiagnostikas metodēm, tādām kā CTA vai magnētiskās rezonanses angiogrāfija (MRA), dupleksultrasonogrāfija (USG) un pozitrona emisijas tomogrāfija un datortomogrāfija (PET/CT), patreiz ir iespējams stratificēt CI risku balstoties ne tikai uz stenozes pakāpi, bet arī uz informāciju par pangas raksturojumu, tas ir, cik liels ir risks tās ruptūrai. Pētījumos pierādīja asociāciju starp paaugstinātu cerebrovaskulāru notikumu risku un tādiem pangas morfologisiskajiem parametriem kā plānu kapsulu, tās ulcerāciju, pangas neovaskularizāciju, ehogenitāti, hemorāğiju pašā pangā un relatīvi daudz lipīdu saturošu pangu vai nekrotisku tās serdi. Šie faktori būtu jāņem vērā izvēloties miega artērijas ārstēšanas metodi (Lal et al., 2002; Fisher et al., 2005; Takaya et al., 2006). Piemēram, pacientam ar zemas pakāpes stenozi, bet izčūlojušu pangu, būtu lielāks ieguvums no revaskularizācijas nekā pacientam ar stabilu, biezu pangas fibrozo kapsulu, kas rada asimptomātisku 70\% stenozi. Ja MR novēro saasiņojumu pangā pacientam ar zemas pakāpes stenozi, tad tas ir zināms riska faktors, ka medikamentozā terapija nebūs efektīva, tāpēc šie pacienti iegūs vairāk no miega artērijas endarterektomijas (MEA) (Brinjikji et al., 2016).

Miega artērijas aterosklerozes riska faktori ir līdzīgi citu artēriju aterosklerozes riska faktoriem: paaugstināts holesterīna līmenis, arteriāla hipertensija (AH), smēķēěana un vecums (Tendera et al., 2011). Ir vērojamas arī dzimuma atšķirības - ja salīdzina abus dzimumus 
vienādā vecuma posmā, tad vīriešiem biežāk ir novērota lielākas pakāpes stenoze nekā sievietēm (de Weerd et al., 2009). Turklāt biežāk vīriešiem (66,2\%) nekā sievietēm sastopams tieši lielo artēriju aterosklerozes izraisīts CI (Grau et al., 2001). Koronāra sirds slimība (KSS) ir bieži sastopama pacientiem ar nozīmīgu miega artērijas stenozi (Sulženko \& Pieniazek, 2018), līdz pat 77\% (Hofmann et al., 2005). Perifēro artēriju slimība (PAS) tiek uzskatīta par riska faktoru miega artērijas stenozei (Ahmed \& Al-Khaffaf, 2009; Mathiesen, Joakimsen \& Bonaa, 2001). Salīdzinot miega un citu artēriju aterosklerozes attīstības riska faktorus, tad cukura diabēts (CD) ir viens no miega artērijas aterosklerozes riska faktoriem, lai gan tas salīdzinoši biežāk tomēr ir pacientiem ar PAS (Bonati \& Brown, 2015). Pacientu grupā, kuri ir pārcietuši cerebrālu infarktu, tika novērota ciešāka saistība starp miega artērijas stenozi un smēķēšanu nekā tādiem riska faktoriem kā AH, CD vai hiperholesterinēmija (Mathiesen, Joakimsen \& Bonaa, 2001).

Izstrādājot modeli, kas ļautu paredzēt asimptomātiskas miega artērijas stenozes iespējamību jeb noteikt augsta riska pacientu grupu asimptomātiskai nozīmīgasmiega artērijas stenozei, konstatēja sekojošus riska faktorus: smēķēšana (OR 3,0; 95\%TI: 2,1-4,4), vīrieša dzimums (OR 2,5; 95\% TI: 1,7-3,6), kardiovaskulāra saslimšana anamnēzē (OR 2,5; 95\%TI: 1,7-3,5), vecums (10 gadu laikā) (OR 2,2; 95\% TI: 1,7-2,8), cukura diabēts (OR 1,6; 95\% TI: 1,0-2,5), arteriāla hipertensija (OR 1,3; 95\% TI: 1,2-1,5), hiperholesterinēmija (OR 1,2; 95\%TI: 1,1-1,4) (De Weerd et al., 2014).

\subsubsection{Epidemioloğija}

Aterosklerozes kopējā prevalence nav precīzi zināma, jo tās klīniskā aina nereti ir bez izteikti pamanāmiem simptomiem un to parasti diagnosticē veicot skrīningu, ko savukārt neveic visur un visiem. Turklāt ateroskleroze skar vairāku asinsvadu baseinus, tādējādi visu baseinu aterosklerozes prevalences noteikšana ir apgrūtināta (Bourque \& Kramer, 2011).

Literatūrā pieejamā informācija liecina, ka asimptomātiskas nozīmīgas miega artērijas prevalence vispārējā populācijā variē no 0-3,1\%. Asimptomātiskas vidējas pakāpes (> 50\%) miega artērijas stenozes prevalence vispārējā populācijā ir $2,0 \%$, bet nozīmīgas miega artērijas stenozes $(>70 \%)$ prevalence $-0,5 \%$, kas biežāk ir vīriešiem un pieaug līdz ar vecumu (De Weerd et al., 2010). The Framingham Heart Study kohortas pētījuma rezultāti norāda, ka 75 gadu vecuma grupā miega artērijas stenoze > 50\% ir sastopama $9 \%$ vīriešu un 7\% sieviešu (Pasternak et al., 2004).

No visiem insulta slimniekiem $80 \%$ ir tieši išēmiski insulti (Béjot et al., 2016). Savukārt vairāki populāciju pētījumi norāda, ka 13\% (Kolominsky-Rabas et al., 2001), 15,7\% 
(Palm et al., 2012), 16\% (Petty et al., 1999), 20,9\% (Grau et al., 2001), 16,6\% gadījumu no visiem išēmiskiem insultiem cerebrāla infarkta iemesls ir lielo galvas un kakla artēriju ateroskleroze. Astoņos procentos no visiem išēmiskiem insultiem CI iemesls ir tieši ekstrakraniāla ACI stenoze un 3,5\% - ekstrakraniāla ACI oklūzija (Flaherty et al., 2014). Analizējot 20. gadsimta 80 gadu NASCET pētījumā iekḷautos pacientus ar asimptomātisku miega artērijas stenozi, tika secināts, ka 5 gadu CI risks pacientiem ar 75-94\% asimptomātisku miega artērijas stenozi, kas ārstēta atbilstoši tā laika medikamentozās terapijas principiem, bija līdz pat 18,5\% (Inzitari et al., 2000). Asymptomatic Carotid Artery Stenosis Study (ACAS) pētījumā, kas norisinājās no 1987. līdz 1997. gadam, novēroja, ka konservatīvi ārstētu 60-99\% asimptomātisku stenožu grupā, 5 gadu ipsilaterāla cerebrāla infarkta risks bija 11,0\% (2,2\% gadā) (Walker, 1995), bet Asymptomatic Carotid Surgery Trial (ACST) pētījumā 70-99\% stenožu pakāpes grupā, kas norisinājās no 1993. līdz 2003. gadam, 5 gadu ipsilaterāla cerebrāla infarkta risks bija jau zemāks - 10,0\% (2\% gadā) (Halliday et al., 2010). Šie dati norāda, ka cerebrāla infarkta sastopamības samazināšanās asimptomātiskiem pacientiem saistāma ar intensīvāku un agresīvāku medikamentozās terapijas un riska faktoru modificēšanu (Hadar et al., 2014).

Mirstība no koronārās sirds slimības un insulta Austrumeiropas valstīs ir augstāka nekā Rietumeiropas valstīs. Pēc Eiropas kardiovaskulāro slimību statistikas datiem, vecuma standartizēti mirstības rādītāji Latvijā 2014. gadā vīriešiem bija > 295 uz 100 000, bet sievietēm 151-231 uz 100 000. (Wilkins et al., 2017). Pēc literatūrā publicētiem datiem, ikgadēja pirmreizēja išēmiska insulta gadījumi 2017. gadā bija 10282 (Aguiar de Sousa et al., 2019). Eiropas Savienības veselības uzraudzības institūcija 2017. gadā publicējusi datus, kur nāves iemesls 14\% gadījumi bijis insults (OECD Publishing, 2017), otrais biežākais iemesls pēc išēmiskas sirds slimības. Dati par išēmiska insulta sastopamību Latvijā nozīmīgas miega artērijas stenozes dēḷ pašlaik literatūrā nav pieejami.

\subsubsection{Klīniskā aina}

Progresējot miega artērijas aterosklerozei un palielinoties aterosklerotiskās pangas apjomam, sašaurinās miega artērijas lūmena diametrs, ko nereti pavada arī pangas ulcerācija. Šì procesa rezultātā var parādīties TIL vai išēmisks insults distālas embolizācijas, trombozes vai nozīmīgas miega artērijas stenozes hemodinamikas izraisītu traucējumu dēl (Whisnant, Basford, Bernstein, Cooper, 1990).

Miega artērijas stenoze var izraisīt galvas smadzeṇu pusložu vai okulārus simptomus. Galvas smadzeṇu pusložu išēmija parasti izpaužas ar kontralaterālu hemitipa parēzi vai 
plēg̣iju, hemitipa jušanas traucējumiem, augstākās nervu sistēmas darbības traucējumiem: ja išēmija ir dominantajā puslodē, var novērot afāziju; ja išēmija ir nedominantajā puslodē (labajā) - nolieguma (neglect) sindromu. Savukārt okulārie simptomi izpaužas ar pārejošiem (amaurosis fugax) vai pastāvīgiem monookulāriem redzes traucējumiem.

Miega artērijas stenozi klasificē atkarībā no tā, vai miega artērijas stenoze ir iemesls galvas smadzeņu asinsrites traucējumiem. Par asimptomātisku miega artērijas stenozi pieņemts uzskatīt, ja pēdējo 180 dienu laikā ipsilaterāla iekšējās miega artērijas stenoze nav izraisījusi TIL vai monookulārus redzes traucējumus, kas ilgst $<24$ stundas, vai cerebrālu infarktu atbilstošā apasiņošanas baseinā (Halliday, Thomas \& Mansfiel, 1994). Savukārt par simptomātisku miega artērijas stenozi uzskata, ja pēdējo 180 dienu laikā atbilstoša apasiņošanas baseina TIL vai monookulāri redzes traucējumi, kas ilgs $<24$ stundas, vai cerebrāls infarkts, kura simptomi ilgst $>24$ stundas, ir radušies diagnosticētas ipsilaterālas miega artērijas stenozes dēl (Warlow, 1991; Barnettet al., 1998).

Lai gan TIL vai CI ir biežākie nozīmīgas miega artērijas simptomi, taču ir ar̄̄ vēl citi retāk sastopami klīniski simptomi, kas saistīti ar nosacīti asimptomātisku nozīmīgu miega artērijas stenozi. Literatūrā ir minēts, ka viens no asimptomātiskas nozīmīgas miega artērijas stenozes izraisītiem simptomiem varētu būt samazināta kognitīvā funkcija (Wang, Mei \& Zhang, 2016). Tāpēc tie asimptomātiskas nozīmīgas miega artērijas stenozes pacienti, kuriem nav motoru simptomu, bet ir agrīni kognitīvi traucējumi, varētu tikt novērtēti kā paaugstināta riska vai pat kā simptomātiski pacienti (Dempsey, Varghese, et al., 2017). Turklāt, arī pulsējošs tinnitus var būt nozīmīgas miega artērijas stenozes simptoms (Sismanis, 1998;Daneshi et al., 2004). Kā arī, ir aprakstīti gadījumi par pacientiem ar medikamentozi rezistentu depresiju, kas izzūd pēc miega artērijas endarterektomijas (Coumans \& McGrail, 2000). Tāpēc paliek neskaidrs jautājums, vai vienmēr šo pacientu miega artērijas stenoze vērtējama kā asimptomātiska klasiskās definīcijas izpratnē, vai tomēr simptomātiska. Detalizētāk šis jautājums ir apskatīts 1.2. sadaḷā.

\subsubsection{Diagnostika}

Dupleksultrasonogrāfija parasti ir pirmās izvēles metode salīdzinoši precīzās diagnostikas, plašās pieejamības un zemo izmaksu dēl. CTA un MRA priekšrocība ir tāda, ka šajos izmeklējumos ir iespējams vienlaicīgi analizēt arī aortas loku, no tā atejošās artērijas, miega artērijas bifurkāciju un ACI distālo dalı, kā arī izvērtēt intrakraniālos asinsvadus. Taču šo izmeklējumu trūkumi ir salīdzinoši augstākas izmaksas un nepieciešamība ievadīt kontrastvielu. Veicot pieejamo diagnostisko metožu sensitivitātes metaanalīzi, tika secināts, 
ka duplekss USG, CTA un MRA ir līdzīga precizitāte nozīmīgas miega artērijas stenozes diagnosticēšanā, savukārt vidējas stenozes pakāpes diagnosticēšanā - tā bija atšksirīga (Wardlaw et al., 2006). Eiropas Asinsvadu ķirurgijias biedrības (European Society of Vascular Surgery) vadlīnijas rekomendē duplekss USG (kā izvēles metode), CTA un/vai MRA metodes ekstrakraniālas miega artērijas stenozes pakāpes noteikšanā. Ja tiek apsvērta miega artērijas endarterektomija, tiek rekomendēts pielietot CTA vai MRA pēc sākotnējās duplekss USG, vai atkārtoti veikt duplekss USG, ko veic cits speciālists. Ja tiek apsvērta miega artērijas stentēšana, pēc sākotnējās duplekss USG rekomendē veikt CTA vai MRA, lai novērtētu aortas loku, kā arī ekstra un intrakraniālo asinsvadu stāvokli. Intraarteriālu digitālo subtrakcijas angiogrāfiju nevajadzētu veikt pacientiem, kuriem tiek apsvērta miega artērijas revaskularizācija, izņemot gadījumus, kad neinvazīvo radioloǵisko izmeklējumu rezultāti ir pretrunīgi (Naylor et al., 2018).

\subsection{7. Ārstēšanas metodes}

\subsubsection{Miega artērijas endarterektomija}

Iekšējās miega artērijas endarterektomija ir aterosklerotiskās pangas evakuācija kopā ar asinsvada tunica intima slāni līdz lamina elastica externa līmenim. Pielietotās miega artērijas endarterektomijas tehnikas ir vairākas: konvencionāla miega artērijas endarterektomija ar primāru šuvi, konvencionāla miega artērijas endarterektomija ar ielāpu, eversijas miega artērijas endarterektomija (Zarins \& Gewertz, 2005). Eiropas Asinsvadu ķ̧irurǵijas asociācijas vadlīnijas rekomendē tieši eversijas miega artērijas endarterektomiju kāa pirmo izvēles metodi nevis konvencionālo miega artērijas endarterektomiju ar primāru šuvi. Savukārt izvēli starp eversijas endarterektomiju un konvenciālo miega artērijas endarterektomiju ar ielāpu vajadzētu atstāt katra konkrētā ķirurga izvēlē atkarībā no viņa pieredzes un kompetences (Naylor et al., 2018).

\subsubsection{Miega artērijas perkutāna translumināla angioplastija un stentēšana}

Miega artērijas perkutāna translumināla angioplastija un stentēšana (PTA) pēdējos gados ir ievērojami mainījusi iekšējās miega artērijas stenozes ārstēšanas iespējas. Lai gan šobrīd randomizētu kontrolētu pētījumu metaanalīzes norāda, ka PTA paaugstina periproceduāla, klīniski vieglāka CI risku mikroembolizācijas dēḷ vairāk nekā MEA, tomēr attīstoties miega artērijas angioplastijas tehnologijām, domājams PTA periproceduālais risks 
varētu samazināties un abas revaskularizācijas metodes, iespējams, būs līdzvērtīgas (Setacci et al., 2017).

Pašlaik PTA var tikt apsvērta kā izvēles metode ķirurğiski augsta riska pacientiem ar izteiktu sirds mazspēju ( III/IV pakāpe pēc NYHA), kreisā kambara izsviedes frakciju < 30\%, nestabilu stenokardiju, pretējās puses miega artērijas oklūziju, nesenu miokarda infarktu (MI), iepriekš veiktu MEA restenozi un iepriekš veiktu staru terapiju kakla rajonā (Ahn, Prince \& Dubel, 2013). PTA nav iedomājama bez medikamentozās terapijas: statīnu un antiagregantu lietošana pirms PTA samazina periproceduālo komplikāciju risku. Rekomendē duālu antiagregantu terapiju ar aspirīnu (300 mg sākotnēji pirmās 14 dienas, tad 75 mg, ja vien pirms tam jau nav lietots aspirīns) un klopidogrelu (75 mg) 3-5 dienas pirms PTA. Duālus antiagregantus jāturpina vizmaz 1 mēnesi, tad turpina ar klopidogrelu, ja vien ārstējošais ārsts neuzsāk citu alternatīvu antiagregantu ilgtermiņa aterosklerozes ārstēšanai, piemēram, kardiovaskulāru slimību dēḷ. Veicot stentēšanu rekomendē lietot embolu protekcijas ierīces (embolic protection device), ja vien nav kontrindikāciju vājas kollaterālās asinsvadu sistēmas dēl (Naylor et al., 2018).

\subsubsection{Medikamentoza ärstēšana}

Pie iekšējās miega artērijas medikamentozās sekundārās un terciārās profilakses pieder riska faktoru modificēšana, antiagregantu unlipīdu līmeņa samazinoša terapija, arteriālās hipertensijas un CD kontrole, kā arī, l̦oti būtiski, pacientu līdzestības nodrošināšana medikamentozai terapijai (Naylor et al., 2018).

\subsubsection{Simptomātiskas miega artērijas stenozes ārstēšana}

\subsubsection{Endarterektomija vai medikamentoza ārstēšana}

Cochrane sistēmiskajā literatūras apskatā secināja, ka MEA simptomātiskiem pacientiem palielina 5 gadu ipsilaterāla CI risku, ja stenoze ir mazāka par 30\% (n = 1746, risk ratio (RR) 1,27; 95\% TI: 0,80-2,01). Pacientiem, kuriem ir 30-49\% simptomātiska miega artērijas stenoze, nav nozīmīga vai ievērojama labuma no MEA ( $\mathrm{n}=1429$, RR 0,93; 95\%TI: 0,62-1,38). Savukārt ja miega artērijas stenoze ir 50-69\%, tad ir vērojams neliels ieguvums ( $\mathrm{n}=1549$, RR 0,84; 95\%TI: 0,6-1,18). Ja stenoze ir 70-99\%, ieguvums ir ievērojams, izṇemot atsevišksus nozīmīgas miega artērijas stenozes suboklūzijas (95-99\% stenoze) gadījumus, kur ieguvums no MEA netika novērots (Orrapin \& Rerkasem, 
2017). Tomēr ir jāmin, ka šis sistēmiskais literatūras apskats iekḷāva pētījumus, kas veikti 1980-tajos un 1990-to gadu sākumā, kad vēl netika plaši pielietoti statīni un citi medikamenti miega artērijas stenozes ārstēšanā (Marquardt et al., 2010). Tāpēc domājams, ka ieguvumi no MEA būtu mazāki, un šobrīd pieejamā medikamentozā ārstēšana ar statīniem un citiem jaunās paaudzes medikamentiem varētu būt laba izvēle, lai samazinātu ne tikai ipsilaterāla CI risku, bet arī lai samazinātu perioperatīva insulta un nāves risku pacientiem ar vidējas pakāpes (50-69\%) stenozi (Orrapin \& Rerkasem, 2017).

Ir zināms, ka pacientiem ar simptomātisku 50-99\% stenozi atkārtota CI risks pirmajās 72 stundās ir 8-15\% (Ois et al., 2009). Tāpēc ne tikai stenozes pakāpei ir nozīme, bet arī citiem riska faktoriem. Naylor et al. vairāku randomizēti kontrolētu pētījumu (RCT) literatūras apskatā secina, ka šobrīd nav precīzi validēti dati vai parametri, lai identificētu pacientus, kuriem būtu nepieciešams veikt neatliekamu MEA. Bet šo pacientu identifikācijai varētu izmantot tos parametrus, kas nosaka palielinātu atkārtotu CI risku vēlīnā periodā. Zināms, ka klīniskie parametri paaugstinātam atkārtotam CI riskam pirmajos trīs mēnešos ir sekojoši: vīriešu dzimums; vecums > 75 gadi; atbilstošs pusložu fokāls neirologiskais deficīts un vairākas blakussaslimšanas. Bet zināmie attēldiagnostikas parametri: nelīdzena stenoze, īpaši, ja ir lielas pakāpes stenoze; pretējās miega artērijas oklūzija; tandēma intrakraniāla stenoze; sliktas intrakraniālas kollaterāles; zems Gray Scale Median (GMS) rādītājs pangas stabilitātes novērtēšanā, MR vērojams saasiņojums paša pangā; palielināta fluordeoksiglikozes krāšanās pangā PET/CT izmeklējumā. Klīniskie un attēldiagnostikas parametri, kas norāda par zemāku risku atkārtotam CI vēlīnā periodā ir: sievietes, īpaši tās, kurām miega artērijas stenozes ir 50-99\%; tādi simptomi kā amaurosis fugax vai lakunārs CI; līdzena, kalcinēta panga un hroniska suboklūzija. Pašlaik visiem pacientiem ar simptomātisku 50-99\% stenozi tiek rekomendēts apsvērt MEA vai PTA. Tomēr pētījumi, pēc kuru rezultātiem varētu izveidot algoritmu, kas ļautu klīniskā praksē identificēt zema līdz vidēja riska atkārtota CI pacientus, turpinās. Teorētiski š̄is grupas pacientus varētu ārstēt medikamentozi, tādējādi optimizējot gan log̣istiskos, gan finansiālos resursus tām slimnīcām, kas nodrošinātu akūtu MEA augsta atkārtota CI riska pacientiem (Naylor, Sillesen \& Schroeder, 2015).

\subsubsection{Endarterektomija vai perkutāna translumināla angioplastija un stentēšana}

Kopš 20. gadsimta 50 gadiem ir interese par simptomātiskas miega artērijas ārstēšanas iespējām. Pirmās veiksmīgās miega artērijas operācijas veiktas 1951. gadā, savukārt pirmie ziņojumi par miega artērijas stentēšanu bija 1994. gadā. Pēc pirmajām veiksmīgajām miega 
artērijas revaskularizācijas procedūrām, tika uzsākti randomizēti kontrolēti pētījumi, lai iegūtu informāciju, kura no ārstēšnas metodēm būtu piemērotāka pacientiem ar nozīmīgu miega artērijas stenozi (Morris et al., 2017). Cochrane metaanalīze norāda, ka augstāks perioperatīvais mirstības un insulta risks bija pacientiem pēc PTA biežāka, klīniski vieglāka CI dēḷ, bet 30 dienu mirstības un smaga CI riska rādītājos atšķiirības starp MEA un PTA nebija (OR 1,28; 95\% TI: 0,93-1,77, p=0,13), (Bonati et al., 2012). MEA pacientiem biežāk novēroja kraniālo nervu bojājumus un perioperatīvu MI (Meier et al., 2010). Tā kā pēdējo gadu dažādu autoru metaanalīzes norāda, ka PTA tomēr ir saistīta ar palielinātu abu iznākumu risku - ne tikai ar periproceduālo, bet arī ar vidēja un ilgtermiņa iznākumu, tad MEA rekomendē kā izvēles metodi simptomātiskas nozīmīgas miega artērijas ārstēšanā. Bet ir nepieciešami turpmāki pētījumi, lai novērtētu abu metožu efektivitāti, ņemot vēra to, ka nemitīgi turpinās medikamentozās terapijas un endovaskulāro procedūru tehnolog̣iju attīstība un uzlabojumi. (Luebke \& Brunkwall, 2016; Vincent et al., 2015; Li et al., 2017; Zhang et al., 2015)

\subsubsection{Eiropas Asinsvadu ķirurgijas biedrības rekomendācijas (Naylor et al., 2018)}

MEA tiek rekomendēta pacientiem ar nozīmīgu miega artērijas stenozi (70-99\%), kuriem pēdējo 6 mēnešu laikā ir bijuši simptomi no miega artērijas apasiņošanas baseina, un/ja dokumentētais periproceduālais insulta vai nāves risks ir < 6\% (I klase, A līmenis).

MEA varētu tikt apsvērta pacientiem ar miega artērijas stenozi 50-69\%, kuriem pēdējo 6 mēnešu laikā ir bijuši simptomi no miega artērijas apasiņošanas baseina, un/ja dokumentētais periproceduālais insulta vai nāves risks ir < 6\% (IIa klase, A līmenis).

Pacientiem ar miega artērijas stenozi 50-99\%, kuriem pēdējo 6 mēnešu laikā ir bijuši simptomi no miega artērijas apasiņošanas baseina un kas vecāki par 70 gadiem, būtu jāveic MEA nevis PTA (I klase, A līmenis).

Pacientiem ar simptomātisku miega artērijas stenozi, kuriem pēdējo 6 mēnešu laikā ir bijuši simptomi no miega artērijas apasiņošanas baseina un kuriem ir indicēta revaskularizācija, un kuri ir jaunāki par 70 gadiem, PTA varētu būt kā alternatīva MEA un/ja dokumentētais periproceduālais insulta vai nāves risks ir < 6\% (IIb klase, A līmenis).

MEA vai PTA netiek rekomendētas simptomātiskiem pacientiem ar hronisku iekšējās miega artērijas suboklūziju, ja vien tā nav asociēta ar atkārtotiem ipsilaterāliem simptomiem (neskatoties uz optimālu medikamentozu terapiju) un ja šāda veida stenozes ārstēšanas taktika tiek pārrunāta ar multidisciplināru komandu (III klase, C līmenis). 
Miega artērijas revaskularizāciju vajadzētu atlikt pacientiem ar miega artērijas 50-99\% stenozi, kuriem ir klīniski smagas pakāpes CI ( $\mathrm{mRS} \geq 3$ ), kuriem infarkta zona ir lielāka par vienu trešdaļu no ipsilaterālās arteria cerebri media teritorijas, vai kuriem ir traucēta samaņa, lai samazinātu postoperatīvu galvas smadzeņu parenhīmas hemorāgijijas risku (I klase, C lìmenis).

Pacientiem ar simptomātisku 50-99\% miega artērijas stenozi un CI, kura apjoms varētu paalielināties, vai atkārtotas TIL, vajadzētu apsvērt veikt neatliekamu, steidzamu MEA, vislabāk < 24 stundu laikā (IIa klase, C līmenis).

Visiem pacientiem ar simptomātisku miega artērijas stenozi rekomendē veselīgu uzturu, smēķēěanas atmešanu un fiziskās aktivitātes (I klase, B līmenis).

Antiagregantu terapija tiek rekomendēta pacientiem ar 50-99\% simptomātisku miega artērijas stenozi, kuriem neveic miega artērijas endarterektomiju vai stentēšanu. Pirmās izvēles medikamenti ir klopidogrels 75 mg vai aspirīns 75 mg 1 reizi dienā kopā ar garas darbības dipiridamolu 200 mg 2 reizes dienā. Ja nepanes klopidogrelu vai dipiridamolu, tad rekomendē aspirīnu monoterpijā (75-325 mg). Ja nepanes aspirīnu un klopidogrelu, rekomendē garas darbības dipiridamolu 200 mg 2 reizes dienā (I klase, A līmenis).

Visiem pacientiem, kam veic MEA, vajadzētu saņemt antiagregantu terapiju visā perioperatīvā perioda laikā un arī turpmāk ilgtermiņā (I klase, B līmenis). Pacientiem, kam veic MEA rekomendē labāk zemu devu (75-325 mg) nevis lielu devu (> $625 \mathrm{mg}$ ) aspirīnu (I klase, B līmenis).

Agrīna aspirīna + klopidogrela (vai aspirīns + garas darbības dipiridamols) uzsākšana pēc TIL vai CI bez nozīmīga neiroloǵiskā defekta varētu tikt apsvērta, lai samazinātu agrīnus atkārtotus cerebrovaskulārus notikumus pacientiem ar > 50\% miega artērijas stenozi, ja šie pacienti gaida MEA (IIb klase, C līmenis).

Pacientiem, kam plāno veikt PTA, rekomendē duālu antiagregantu terapiju ar aspirīnu (75-325 mg 1 reizi dienā) un klopidogrelu (75 mg 1 reizi dienā). Klopidogrels būtu jāuzsāk vismaz 3 dienas pirms paredzētās PTA vai arī jāsaņem 300 mg kā bolusa deva neatliekamās steidzamās situācijās. Aspirīnu un klopidogrelu vajadzētu lietot vismaz 4 nedēḷas pēc miega artērijas stentēšanas un turpināt optimālu ilgtermiņa sekundāro profilaksi arvienu noantiagregantiem (I klase, B līmenis).

Ilgtermiņa duāla antiagregantu aspirīna un klopidogrela lietošana netiek rekomendēta pacientiem, kuriem veikta MEA vai PTA, ja vien nav kardiologiskas indikācijas (III klase, C līmenis).

Gastroprotekciju vai protona sūkṇa inhibitoru lietošanu ar pantoprazolu vajadzētu apsvērt pacientiem, kuriem rekomendēts klopidogrels, un kuriem ir viens vai vairāki riska 
faktori asiņošanai no kunǵa - zarnu trakta (anamnēze par iepriekšēju asiņošanu no kuņǵa - zarnu trakta, lielāks vecums, Helicobacter pylori infekcija un vienlaicīga aspirīna vai citu nesterōido pretiekaisuma līdzekḷu, antikoagulantu, selektīvo serotonīna atpakaļsaistīšanās inhibitoru vai sterō̄du lietošana (IIa klase, B līmenis).

Rekomendē uzsākt statīnu terapiju pirms MEA vai PTA un tos nevajadzētu pārtraukt perioperatīvā periodā, tos vajadzētu lietot ilgstoši (Class I, B līmenis).

Antihipertensīva terapija tiek rekomendēta pacientiem ar AH un simptomātisku ekstrakraniālu iekšējās miega artērijas stenozi, lai ilgtermiņā nodrošinātu asinsspiedienu $<$ 140/90 mmHg (I klase, A līmenis).

Agrīnā simptomu periodā īsi pirms MEA vai PTA ievērojama asinsspiediena samazināšana jāveic uzman̄̄gi, bet nekontrolētai hipertensijai (> 180/90 mmHg) vajadzētu būt ārstētai (IIa klase, C līmenis).

\subsubsection{Asimptomātiskas miega artērijas stenozes ārstēšana}

\subsubsection{Endarterektomija vai medikamentoza ārstēšana}

Šobrīd vienīgie randomizēti kontrolētie pētījumi, kuri ir salīdzinājuši MEA un labāko medikamentozo terapiju asimptomātiskiem miega artērijas pacientiem ir Veteran's Affairs Cooperative Study (VACS), Asymptomatic Carotid Artery Stenosis Study (ACAS) un Asymptomatic Carotid Surgery Trial-1 (ACST-1) pētījumi, kas rekrutēja pacientus no 1983. līdz 2003. gadam. VACS pētījumā 4 gadu ipsilaterāla insulta risks, ieskaitot perioperatīvu insultu vai nāvi MEA grupā bija 7,0\%, bet medikamentozā grupā - 9,4\% (Hobson et al., 1993). ACAS pētījumā 5 gadu ipsilaterāla insulta risks un jebkura perioperatīva insulta vai nāves risks MEA grupā, kuriem miega artērijas stenoze bija $>60 \%$, bija 5,1\%, bet medikamentozajā grupā 11,0\%, ar noteikumu, ka MEA tika veikta ar mazāk kā 3\% perioperatīvu insulta un mirstības iespēju (Walker, 1995). Savukārt analizējot jebkura insulta risku, ACAS un ACST-1 pētījumi uzrādīja, ka pacientiem ar $>60 \%$ stenozi MEA samazina jebkāda išēmiska insulta risku 5 gadu laikā, ieskaitot perioperatīvu nāves/CI risku, ja salīdzina ar medikamentozo grupu (ACAS: 12,4\% vs. 17,8\%; ACST-1: 6,4\% vs. 11,8\%), (Walker, 1995; Halliday et al., 2010). Šo pêtījumu rezultāti tajā laikā norādīja, ka MEA asimptomātiskiem pacientiem ievērojami samazina ipsilaterāla vai jebkura CI risku (Chambers \& Donnan, 2005), tāpēc MEA tika rekomendēta asimptomātiskiem pacientiem ar nozīmīgu miega artērijas stenozi, ja vien 30 dienu mirstības un perioperatīva insulta rādītāji bija $<3 \%$ un paredzamā dzīvildze $>5$ gadi. Taču jāatceras tas, ka šie pētījumi norisinājās tajā 
laikā, kad medikamentozā terapijā nelietoja statīnus un lielākā pacientu daļa smēķēja. Tāpēc, veicot 41 pētījuma metaanalīzi, konstatēja, ka pētījumos, kuri rekrutēja pacientus pirms 2000. gada, pacientiem ar asimptomātisku miega artērijas stenozi ipsilaterāla insulta sastopamība bija 2,3/100 persongadiem. Taču pētījumos, kuri rekrutēja pacientus laika posmā no 2000. līdz 2010. gadam, ipsilaterāla insulta incidence medikamentozā grupā pacientiem ar nozīmīgu asimptomātiskumiega artērijas stenozi bija 1,0/100 persongadiem $(p<0,001)$ (Hadar et al., 2014). Ipsilaterāla insulta sastopamības samazināšanās par 39\% 19 gadu laikā ir izskaidrojama ar medikamentozās terapijas uzlabošanos un smēķēšanas ierobežojumiem (Naylor et al., 2018). Tāpēc iepriekš iegūtie dati, kas norādīja par mazāku CI risku asimptomātiskas miega artērijas pacientiem nekā iepriekš uzskatīts, ir veicinājuši uzsākt jaunus RCT kā Carotid Revascularisation and Medical Management for Asymptomatic Carotid Stenosis-2 (CREST-2), ECST-2, ACST-2, kur tiek salīdzinātas asimptomātiskas miega artērijas stenozes revaskularizācijas un medikamentozās terapijas grupas (Mott, Koroshetz \& Wright, 2017; Stroke Research Group, 2018; Bulbulia \& Halliday, 2017).

\subsubsection{Endarterektomija vai perkutāna translumināla angioplastija un stentēšana}

Literatūrā zināmie RCT, kas salīdzināja MEA un PTA asimptomātiskiem nozīmīgas miega artērijas stenozes pacientiem, ir CREST-1 un Asymptomatic Carotid Trial (ACT-1) pētījumi (Brott et al., 2010; Rosenfield et al., 2016). Cochrane sistēmiskajā apskatā, salīdzinot MEA ar PTA, secina, ka nav nozīmīgas atšksirības 30 dienu mirstības un jebkura CI veida biežumā starp abām grupām (OR 1,71; 95\%TI: 0,78-3,76, $p=0,18$ ). Bet analizējot 30 dienu mirstību un ipsilaterāla CI risku pēc revaskularizācijas, tika novērota nenozīmīga atšķirīiba starp grupām par labu MEA (OR 1,75; 95\% TI: 0,92-3,33, p=0,09) (Bonati et al., 2012). Savukārt sistēmiski literatūras apskati un RCT metaanalīze, kur salīdzināja MEA un PTA efektivitāti asimptomātiskiem pacientiem, secināja, ka ilgtermiņa iznākums attiecībā uz mirstību un CI nav piln̄̄gi skaidrs. Tā kā tieši 30 dienu periproceduālais CI un nāves risks bija lielāks pacientiem, kuriem veica PTA, tad MEA rekomendē kā izvēles metodi pacientiem ar asimptomātisku miega artērijas stenozi. Taču nākotnē ir nepieciešami augstas kvalitātes pētījumi, kas tiešām pierādītu MEA priekšrocības pār PTA (Moresoli et al., 2017; Kakkos et al., 2017). 


\subsubsection{Medikamentoza ārstēšana}

Dati par asimptomātiskas miega artērijas stenozes medikamentozo ārstēšanu nav viennozīmīgi, jo liela dạ̧a RCT (ACAS, ACST) tika veikti 90-gadu beigās, kad antiagregantu un statīnu lietošanas rekomendācijas atšķīāās no mūsdienu ārstēšanas taktikas. Pētījumos, kur vairāk kā 25\% no pacientiem lietoja statīnus, konstatēja ievērojami zemāku ipsilaterāla CI risku nekā tajā grupā, kur statīnus lietoja < 25\% pacientu (1,2 uz 100 persongadiem pret 2,3 uz 100 persongadiem), $p=0,009$ (Hadar et al., 2014). Iepriekš jau minēju, ka asimptomātiskas miega artērijas medikamentozās terpijas pētījumu metaanalīzē secināja, ka ipsilaterāla CI incidence ir bijusi ievērojami zemāka laika posmā no 2000. līdz 2010. gadam nekā pētījumos, kas tika veikti agrāk, tas ir, 1,0 pret 2,3 notikumiem uz 100 persongadiem. Kāa arī ipsilaterāla CI un ipsilaterāla CI vai TIL incidence pacientiem ar asimptomātisku stenozi medikamentozā grupā pēdējo 25 gadu laikā ir ievērojami mazinājusies - aptuveni par $40 \%$ (Hadar et al., 2014). Šie dati ir izraisījuši diskusijas, tāpēc RCT pētījumi par asimptomātiskas miega artērijas stenozes ārstēšanas taktiku, ņemot vērā mūsdienu medikamentozās terapijas efektivitāti, tiek turpināti (Howardet al., 2017; ACTRIS, 2018).

\subsubsection{Eiropas Asinsvadu ķirurǵijas biedrības rekomendācijas (Naylor et al., 2018)}

"Vidēja ķirurğiskā riska" pacientiem ar asimptomātisku 60-99\% stenozi MEA vajadzētu apsvērt, ja attēldiagnostikā ir viens vai vairāki raksturlielumi, kas norāda par palielinātu risku vēlīnam ipsilaterālam CI, un ja dokumentētais perioperatīvais insulta/nāves risks ir <3\%, kā arī ja pacienta sagaidāmā dzīvildze ir vairāk kā 5 gadi (IIa klase, B līmenis).

Attēldiagnostikas un klīniskie kritēriji, kas varētu liecināt par paaugstinātu risku vēlīnam insultam, lietojot tikai medikamentozo terapiju, ir subklīniski jeb tā saukti "klusi" išēmiski infarkti datortomogrāfijā, stenozes pakāpes progrešējoša sašaurināšanās, liela apjoma panga, liela juksta-lumināla pangas melnā zona, pangas ehogenitāte, saasiņojums pangā, izmainīta cerebrovaskulārā rezerve, spontāni mikroembolu signāli.

"Vidēja ķirurğiska riska" pacientiem ar asimptomātisku 60-99\% stenozi, kuriem ir viens vai vairāki attēldiagnostikas raksturlielumi, kas norāda uz palielinātu risku vēlīnam išēmiskam CI, PTA varētu būt kā alternatīva MEA, ja dokumentētais perioperatīvais insulta/nāves risks ir < 3\% un pacienta sagaidāmā dzīvildze ir vairāk kā 5 gadi (IIb klase, B līmenis).

PTA rekomendē selektīvi atlasītiem pacientiem ar asimptomātisku 60-99\% stenozi, kuri pēc multidisciplināras komandas domām ir augsta ķirurğiska riska pacienti un kuriem ir 
viens vai vairāki attēldiagnostikas raksturlielumi, kas norāda par palielinātu risku vēlīnam išēmiskam CI, ja dokumentētais perioperatīvais insulta/nāves risks ir $<3 \%$ un pacienta sagaidāmā dzīvildze ir vairāk kā 5 gadi (IIb klase, B līmenis).

"Augsta ķirurğiska riska" pacienti ar asimptomātisku miega artērijas 70-99\% stenozi tiek uzskatīti, ja ir viens vai vairāki minētie kritēriji: klīniski nozīmīga kardiāla patoloǵija (hroniska sirds mazspēja, koronāra sirds slimība vai nepieciešamība pēc sirds operācijas); smaga pulmonāla saslimšana; kontralaterālās miega artērijas oklūzija, pretējās puses n.laryngeus parēze; anamnēzē iepriekš veikta radikāla operatīva ārstēšana kakla daļā; anamnēzē staru terapija kakla dal̦ā; restenoze pēc MEA un vecums vairāk kā 80 gadi (Yadav et al., 2004).

Visiem pacientiem ar asimptomātisku miega artērijas stenozi rekomendē veselīgu uzturu, smēķēěanas atmešanu un fiziskās aktivitātes (I klase, C līmenis).

Zemu devu aspirīns (75-325 mg) tiek rekomendēts pacientiem ar asimptomātisku miega artērijas stenozi, lai novērstu vēlīnu miokarda infarktu un citus kardiovaskulāros notikumus (I klase, A līmenis). Apsvērt lietot klopidogrelu 75 mg 1 reizi dienā pacientiem ar asimptomātisku miega artērijas stenozi, ja pacients nepanes aspirīnu (IIa klase, C līmenis).

Tiek rekomendēts lietot statīnus ilgtermiṇā, lai samazinātu insulta, miokarda infarkta un citu kardiovaskulāro notikumu sastopamību pacientiem ar asimptomātisku miega artērijas stenozi (I klase, A līmenis).

Antihipertensīva terapija tiek rekomendēta pacientiem ar arteriālu hipertensiju un asimptomātisku ekstrakraniālās iekšejās miega artērijas stenozi, lai nodrošinātu ilgstoši normālu asinsspiedienu (< 140/90mmHg) (IIa klase, C līmenis).

\subsubsection{Citu vadlīniju rekomendācijas miega artērijas stenozes ārstēšanā}

\subsubsection{Simptomātiskas miega artērijas ārstēšana}

Eiropas Kardiologu biedrības (ESC) vadlīnijas (Tendera et al., 2011):

Pacientiem ar simptomātisku 70-99\% iekšējās miega artērijas stenozi MEA tiek rekomendēta, lai samazinātu atkārtota CI risku (I klase, A līmenis). Pacientiem ar simptomātisku 50-69\% iekšējās miega artērijas stenozi MEA vajadzētu apsvērt, lai samazinātu atkārtota CI risku atkarībā no pacienta klīniskiem faktoriem (IIa klase, B līmenis). Pacientiem ar simptomātisku miega artērijas stenozi, kuriem nepieciešama revaskularizācija, bet ir augsts ķirurğisks risks, PTA varētu būt kā alternatīva metode MEA (IIa klase, B līmenis). 
Asinsvadu ķirurğijas biedrības (SVS) vadlīnijas (Ricotta et al., 2011):

Lielākai dạ̦ai pacientu ar nozīmīgu miega artērijas stenozi, kuriem nepieciešams veikt revaskularizāciju, lai samazinātu CI un periproceduālo mirstību, MEA ir kā pirmās izvēles metode nevis PTA (I klase, B līmenis). Dati no CREST pētījuma norāda, ka pacientiem, kuri jaunāki par 70 gadiem, PTA būtu kā izvēles metode, bet ir nepieciešami citi pētîjumi, kas to apstiprina. PTA ir pārāka par MEA pacientiem ar simptomātisku $\geq 50 \%$ stenozi, ja iepriekš tiem ir bijusi ipsilaterāla operācija kakla rajonā, traheostoma, staru terapija kakla rajonā vai iepriekš zināma kraniālo nervu parēze vai bojājums kakla rajonā (II klase, B līmenis). PTA ir pārāka pār MEA pacientiem ar simptomātisku $\geq 50 \%$ stenozi, ja pacienam ir nopietnas blakussaslimšanas tādas kā koronāra sirds slimība, hroniska sirds mazspēja vai hroniska obstruktīva plaušu slimība (II klase, C līmenis).

Amerikas Kardiologu koledžas biedrības/Amerikas sirds biedrības (ACC/AHA) vadlīnijas (Brott et al., 2011):

Pacientiem ar zemu vai vidēju ķirurğisku risku, kuriem pēdējo 6 mēnešu laikā ir bijis klīniski viegls išēmisks insults, TIL vai amaurosis fugax, būtu jāveic MEA, ja ipsilaterālās iekšêjās miega artērijas lūmena diametrs ir samazināts par $>70 \%$ pēc neinvazīvām attēldiagnostikas metodēm (I klase, A līmenis) vai vairāk kā 50\% pēc DSA (I klase, B līmenis) un paredzamais perioperatīvā insulta un nāves risks ir mazāks par 6\%. PTA ir indicēta kā alternatīva ārstēšanas metode pacientiem ar simptomātisku miega artērijas stenozi, ja ir zems vai vidējs risks komplikācijām, kas saistītas ar endovaskulāru ārstēšanu, kur miega artērijas diametrs ir samazināts par $>70 \%$ pēc neinvazīvām attēldiagnostikas metodēm vai vairāk kā $50 \%$ pēc DSA, kā arī paredzamais perioperatīvā insulta un nāves risks ir mazāks par 6\% (I klase, B līmenis). PTA būtu jāizvēlas MEA vietā, ja revaskularizācija ir indicēta pacientam, kuram anatomisku īpatnību dēḷ veikt MEA ir apgrūtinoši (IIa klase, B līmenis).

\subsubsection{Asimptomātiskas miega artēerijas ārstē̌̌ana}

Eiropas Kardiologu biedrības (ESC) vadlīnijas (Tendera et al., 2011):

Pacientiem ar asimptomātisku $\geq 60 \%$ miega artērijas stenozi, MEA varadzētu apsvērt, ja vien periproceduālais insulta un nāves risks ir $<3 \%$ un paredzamā pacienta dzīvildze ir $>5$ gadi (IIa klase, A līmenis). Pacientiem ar asimptomātisku miega artērijas stenozi, kuriem ir indicēta revaskularizācija, PTA varētu tikt apsvērta kā alternatīva MEA augsta profesionālā līmeña centros, kur insulta un nāves risks ir $<3 \%$ (IIb klase, B līmenis).

Asinsvadu ķirurğijas biedrības (SVS) vadlīnijas (Ricotta et al., 2011):

Pacientiem ar asimptomātisku $\geq 60 \%$ miega artērijas stenozi rekomendē veikt MEA, lai 
samazinātu ilgtermiņa CI risku, ja paredzamā dzīvildze ir vismaz 3-5 gadi un perioperatīvā insulta un nāves risks ir $\leq 3 \%$ (I klase, A līmenis). Nav pietiekoši dati, lai rekomendētu PTA kā pirmo izvēles metodi asimptomātiskiem 70-99\% miega artērijas stenozes pacientiem. CREST pētījuma dati liecina, ka adekvāti izvēlētiem asimptomātiskiem pacientiem PTA ir vienlīdz efektīvakā MEA, ja to veic pieredzējis invazīvais radiologs. Gan invazīviem radiologiem, gan ārstniecības iestādei, kas veic PTA, ir jāatbilst iepriekš Amerikas sirds asociācijas noteiktiem kritērijiem, kas publicēti iepriekšējās vadlīnijās par asimptomātiskas miega artērijas stenozes ārstēšanu. Kopējam insulta un nāves riskam ir jābūt $<3 \%$, lai nodrošinātu ieguvumu no šīs procedūras (II klase, B līmenis).

Amerikas Kardiologu koledžas biedrības/Amerikas sirds biedrības (ACC/AHA) vadlīnijas (Brott et al., 2011):

Asimptomātisku nozīmīgas miega artērijas stenozes pacientu atlase, kurai būtu nepieciešama revaskularizācija, jāizvērtē atkarībā no blakussaslimšanām, paredzamās dzīvildzes un citiem individuāliem faktoriem. Ir nepieciešamas diskusijas, pārrunas ar pacientu, lai novērtētu procedūras riskus un ieguvumus (I klase, C līmenis). MEA būtu pamatoti veikt asimptomātiskiem pacientiem ar > 70\% iekšèjās miega artērijas stenozi, ja perioperatīvā insulta, MI un nāves risks ir zems (IIa klase, A līmenis). Profilaktiska PTA varētu būt apsverama tikai rūpīgi izvēlētiem pacientiem ar asimptomātisku miega artērijas stenozi, kas ir $>60 \%$ pēc CTA vai $>70 \%$ pēc doplerogrāfijas, tomēr š̄is procedūras efektivitāte salīdzinājumā ar medikamentozo terapiju nav skaidri zināma (IIb klase, B līmenis).

\subsection{Kognitīvā funkcija un nozīmīga miega arērijas stenoze}

Viegls kognitīvs deficīts (ViKD) izpaužas kā kognitīvās funkcijas pazemināšanās, smaguma ziņā atrodoties starp kognitīvās funkcijas traucējumiem, kas rodas normālas novecošanās rezultātā, un tiem, kas jau atbilst demences kritērijiem. ViKD var iedalīt 2 tipos: amnestiskais un neamnestiskais tips. Amnestiskais ViKD tips raksturojas ar klīniski nozīmīgiem atmiņas traucējumiem, bet tie vēl neatbilst demences kritērijiem. Parasti pacients un piederīgie ir ievērojuši, ka daudzas lietas tiek aizmirstas, taču citas kognitīvās funkcijas spējas (frontālās vadības funkcija, valodas lietojums, vizuāli-telpiskās uztveres spējas) ir relatīvi saglabātas. Neamnestisks ViKD raksturojas ar kognitīvās funkcijas pazemināšanos, bet tā nav saistīta ar atmiņas pasliktināšanos. Tā ietekmē tādus domēnus kā uzmanību, valodas lietojumu vai vizuāli-telpiskās uztveres spējas (Petersen, 2011).

Vaskulārs kognitīvs deficīts (VaKD) ir patoloǵisks stāvoklis, kad kognitīvais deficīts radies cerebrovaskulāru saslimšanu dēḷ (deficīts tikai vienā kognitīvās funkcijas domēnā), bet 
neatbilst demences kritērijiem (deficīts vismaz 2 kognitīvās funkcijas domēnos) (Consoli, Pasi \& Pantoni, 2012). Vaskulāru kognitīvu deficītu var izraisīt dažādu patoǵenēzes mehānismu izraisītas cerebrovaskulāras saslimšanas (multipli cerebrāli infarkti, CI stratēǵiski nozīmīgās vietās, baltās vielas vaskulārs bojājums, lakunāri infarkti, galvas samdzeņu hematomas), tai skaitā arī miega artērijas oklūzija vai miega artērijas nozīmīga stenoze hipoperfūzijas dēḷ pat bez makroskopiski redzama galvas smadzeņu bojājuma. (Iadecola, 2013; Dichgans \& Leys, 2017) Pēc insulta bieži novēro uzmanības, informācijas apstrādes ātrumaun vadības funkcijas pasliktināšanos. Taču zināms, ka arī orientācija, atmiņa un valodas traucējumi ir bieži sastopami pacientiem ar izteiktu kognitīvu deficītu pēc pārciesta insulta. (Stephens et al., 2004; Narasimhalu et al., 2009; Pendlebury et al., 2012)

\subsubsection{Kognitīvo traucējumu patoǵenēzes mehānisms pacientam ar simptomātisku miega artērijas stenozi}

Jau izsenis multipli cerebrāli infarkti ir uzskatīti par vaskulāras demences (VD) iemeslu (Hachinski, Lassen \& Marshall, 1974). Jo lielāka apjoma cerebrāls infarkts un jo to ir vairāk (tai skaitā vairāki sīki subkortikāli infarkti), jo tie ir saistīti ar sliktāku kognitīvo funkciju un lielāku risku demences attīstībai. Tomēr nav precīzi zināms kopējais galvas smadzeņu bojājuma tilpums, kuru sasniedzot attīstās VaKD vai vaskulāra demence. Ir vairāki faktori, kas ierobežo veikt šadus aprēķinus. Pirmais, ir zināmi galvas smadzeņu rajoni, kuru bojājuma gadījumā attīstās izteiktāki kognitīvās funkcijas traucējumi. Otrais, daudziem pacientiem bez vaskulāriem riska faktoriemir tādas blakussaslimšanas kā, piemēram, Alcheimera demence (AD). Trešais, katram cilvēkam ir individuālas, atšķirīigas galvas smadzeņu spējas kompensēt vaskulāro un neirodeǵeneratīvo saslimšanu radītos kognitīvos traucējumus (Dichgans \& Leys, 2017). Izteiktus kognitīvus traucējumus var izraisīt arī viens neliela apjoma CI, ja tas lokalizēts stratēgeiski svarīgā galvas smadzeņu rajonā. Stratēǵiski svarīgi galvas smadzeņu rajoni, kas piedalās kognitīvās funkcijas nodrošināšanā, ir thalamus, gyrus angularis un zemgarozas kodoli, ieskaitot nucleus caudatus un globus pallidus. (Kamondi \& Szirmai, 2002; Jellinger, 2008) Jaunākos pētījumos izmantojot voxel-based magnētisko rezonansi, ir norādījumi arī par baltās vielas traktu (radiatio thalamus anterior un forceps minor) bojājuma nozīmi VaKD attīstībā (Biesbroek et al., 2013). Lai gan pieejamie dati nesniedz pilnīgas zināšanas par visiem VaKD patoǵenēzē iesaistītiem stratēǵiski svarīgiem galvas smadzeņu rajoniem un to savstarpējām saistībām, tomēr valda uzskats, ka mums zināmie stratēgiski svarīgie rajoni ir tikai daḷa no lielākām savstarpējām saistībām un kortikāli-subkortikāliem savienojumiem (Dichgans \& Leys, 2017). 


\subsubsection{Kognitīvo traucējumu patoğenēzes mehānisms pacientiem ar asimptomātisku miega artērijas stenozi}

Pacientiem ar nozīmīgu miega artērijas stenozi kognitīvi traucējumi rodas, domājams, hipoperfūzijas un klīniski nemanāmas mikroembolijas rezultātā. Ir dažādu veidu pētījumi, kuri ir mēǵinājuši pierādīt vai atrast saistības starp kognitīvās funkcijas traucējumiem un iespējamiem patoǵenēzes mehānismiem.

Veselam cilvēkam relatīvi nemain̄̄gu un vienmērīgu cerebrālo asins plūsmu (CBF) pie main̄̄ga arteriāla asinsspiediena nodrošina autoregulācijas mehānismi. To pamatā ir arteriolu gludās muskulatūras šūnu kontrakcija pie palielināta intravaskulāra spiediena, savukārt pie samazināta - vazodilatācija. Tādējādi nemainīga CBF tiek nodrošināta, pielāgojot galvas smadzeṇu asinsvada sieniņas tonusu arteriālā asinsspiediena svārstībām. Savukārt nemainīgs CBFnodrošina pietiekošu asins daudzumu galvas smadzeņu šūnām, kas nepieciešams, lai šūnas varētu veikt savas metabolās un specifiskās funkcijas (Iadecola, 2013). Nozīmīga miega artērijas stenoze, hipoperfūzija, samazina intravaskulāro spiedienu, tāpēc lai nodrošinātu nemainīgu CBF, notiek arteriolu vazodilatācija pateicoties autoregulācijas mehānismiem. Spēju arteriolām mainīt diametru atkarībā no perfūzijas spiediena sauc par cerebrovaskulāro rezervi (CVR). Nozīmīgas miega artērijas stenozes gadījumā, samazinās cerebrālais perfūzijas spiediens, kā rezultātā pieaug $\mathrm{CO}_{2}$ koncentrācija asin̄̄s, kas arī izraisa arteriolu dilatāciju. Nozīmīgas miega artērijas stenozes gadījumā bez samazinātā perfūzijas spiediena samazinās arī CBF, tāpēc šūnas nesaņem pietiekoši daudzumu barības vielas, lai tās varētu normāli funkcionēt. Tā rezultātā ir palielināts risks kognitīvu traucējumu un CI attīstībai. To izteiktāk vēro, ja ir vāji attīstītas kollaterāles un Vilīzija loks (Gupta et al., 2012). N̦emot to vērā, ir izvirzītas hipotēzes par hronisku hipoperfūziju un samazinātu cerebrovaskularo rezervi kā iespējamiem iemesliem kognitīvai disfunkcijai pie nozīmīgas miega artērijas stenozes.

Pētījumos, kur tiek salīdzināta kognitīvā funkcija pacientiem ar asimptomātisku $\geq 50 \%$ miega artērijas stenozi un kontroles grupu, un kuras pēc klīniskā un demogrāfiskāa raksturojuma ir savstarpēji līdzīgas, secina, ka asimptomātiska miega artērijas stenoze ir asociēta ar kognitīviem traucējumiem. Šì saistība ir neatkarīga no zināmiem vaskulāriem riska faktoriem, kas paši par sevi ir vaskulāra kognitīva deficīta riska faktori. Kognitīvie traucējumi biežāk sastopami tādos testos, kas novērtē atmiņu/jaunas informācijas iemācīšanās spēju, kā arī motorās un informācijas apstrādes ātrumu. Turklāt šajos pētījumos kognitīvi traucējumi biežāk bija novērojami tieši tiem pacientiem, kuriem bija samazināta CVR ar vāju kollaterāḷu sistēmu, kas netieši norāda par stenozes saistību ar hipoperfūziju unsmazinātu CVR. (Lal, Dux, et al., 2017; Balucani et al., 2012) Ir zināms, ka samazinoties CBF par 40-50\%, 
samazinās galvas smadzeņu aktivitāte un parādās kognitīva disfunkcija (Marshall et al., 2012). Kognitīvas funkcijas traucējumus pacientiem ar nozīmīgu miega artērijas stenozi ir izdevies pierādīt ne tkai ar detalizēti izstrādātiem neiropsihologiskiem testiem, bet arī ar viegla kognitīva deficīta skrīninga testiem. Izmantojot Mini-mentālā stāvokḷa testu (MMSE), kognitīvās funkcijas traucējumi biežāk tika novēroti pacientiem ar nozīmīgu $\geq 70 \%$ miega artērijas stenozi nekā kontroles grupai (Johnston et al., 2004), jo īpaši tiem, kuriem bija abpusēji samazināta CVR (Buratti et al., 2014). Protams, literatūrā ir sastopami arī tādi pētījumi, kur šo saistību nav izdevies pārliecinoši apstiprināt. Piemēram, Sivestrini et al. pētījumā, kur izvērtēja valodas pielietošanas àtrumu (verbal fluency), nozīmīgas atšķ̄īības starp miega artērijas stenozes grupām ar vai bez CVR traucējumiem un kontroles grupu neatrada (Silvestrini et al., 2009).

Kognitīvās funkcijas pasliktināšanās iespējams ir saistīta arī ar klīniski nemanāmiem mikroemboliem, kas rodas pangas morfologisko izmaiņu dēḷ. Mīkstas pangas, kas satur ateromatozas masas un/vai saasiņojumu pašā pangā, norāda par šīs pangas nestabilitāti. Turklāt pangas kapsula kḷūstot plānākai, ar "putu" un iekaisuma šūnu infiltrāciju, var veidoties mazi izčūlojumi, kuru rezultātā rodas mikroemboli. Savukārt multipli sīki emboli var izraisīt multiplus sīkus infarktus, kurus nevar identificēt kāvienu klīniski nozīmīgu cerebrovaskulāru notikumu, bet gan kā pakāpenisku, progresējošu kognitīvās funkcijas pasliktināšanos (Dempsey et al., 2010).

Viens no pētījumiem, kas analizēja subklīnisku cerebrālu mikroembolu signālu biežumu pacientiem ar AD un VD, novēroja, ka pacienti, kuriem pirmās apskates laikā bija mikroembolu signāli, uzrādīja krietni ātrāku kognitīvas funkcijas pasliktināšanos 6 mēnešos nekā tie demences pacienti, kuriem mikroembolu signālus nereǵistrēja (Purandare, 2009). Citā pētījumā pacientiem ar nozīmīgu asimptomātisku miega artērijas stenozi pangas nestabilitāte tieši korelēja ar vaskulāru kognitīvu deficītu. Tas norāda par nestabilas pangas saistību ar baltās vielas bojājumu un subklīniskiem mikroemboliem (Dempsey, Varghese, et al., 2017). Tāpēc ārstējot pacientus ar miega artērijas stenozi, svarīgi ir novērtēt ne tikai stenozes pakāpi, bet arī pangas stabilitāti, īpaši asimptomātiskiem pacientiem, lai paredzētu pangas ruptūras, mikroembolu un progresējoša galvas smadzeņu bojājuma risku. Turklāt prospektīvā kohortas pētījumā par aterosklerozes ietekmi uz galvas smadzeņu atrofiju tika secināts, ka četru gadu novērošanas laikā gan nozīmīga miega artērijas stenoze pakāpe, gan bilaterāla miega arterijas stenoze ir asociēta ar relatīivu kopējo smadzeņu tilpuma un pelēkās vielas tilpuma samazināšanos (Muller et al., 2011).

Ir izvirzītas arī citas hipotēzes, par to kas varētu veicināt kognitīvu traucējumu attīstību pacientiem ar asimptomātisku miega artērijas stenozi. Miega artērijas stenoze ir kā 
marķieris citiem cerebrovaskulāriem riska faktoriem, kas var bojāt galvas smadzenes un tādējādi izraisīt vaskulārus kognitīvus traucējumus. Daudzi aterosklerotiskas asimptomātiskas miega artērijas stenozes riska faktori ir tie paši, kas demencēm un otrādi. VaKD riska faktori ir vecums, sieviešu dzimums, smēķēěana, samazinātas fiziskās aktivtātes, palielināts ķermeņa svars, AH, CD, palielināts kopējais holesterīna līmenis asin̄̄s (Dichgans \& Leys, 2017). Turklāt miega artērijas intima media biezums (IMT) arī varētu būt kā marķieris vaskulāriem riska faktoriem, kas ir saistīti ar tādiem galvas smadzeņu bojājumiem kā "kluss" cerebrāls infarkts un baltās vielas bojājums, kas attiecīgi veicina kognitīvas funkcijas traucējumus. Patoǵenēzes mehānisma pamatā ir tas, ka aterosklerozes vaskulārie riska faktori izraisa endotēlija disfunkciju, kas, savukārt, ietekmē cerebrovaskulāro autoregulācijas mehānismu. Tā kā dziļo baltās vielas rajonu apasiņo perforanto artēriju gala zari, tad š̄̄s endotêlija disfunkcijas dēḷ tie nav spējīgi pielāgot CBF nervu šūnu metabolām prasībām. Tā rezultātā rodas baltās vielas bojājums arteriāla asins spiediena fluktuāciju laikā (Iadecola, 2013). The Framingham Study pētījums secināja, ka ACI stenoze > 50\% vai palielināts ACI IMT (bet ne ACC) ir asociēti ar MR pierādītām išēmiskām izmaiņām ("kluss" CI un plašs baltās vielas bojājums) un kognitīviem traucējumiem (Romero et al., 2009). Citā prospektīvā 7 gadu kohortas pētījumā arī secina, ka miega artērijas ateroskleroze ir saistīta ar paaugstinātu vaskulāras demences attīstības risku (Wendell et al., 2012). Tromso populācijas pētījumā novēroja ciešu saistību starp miega artērijas stenozi un kognitīvas funkcijas pasliktināšanos. Taču šì sakarība nebija atkarīga no galvas smadzeņu bojājuma plašuma, tas ir, kortikālas išēmiskas izmaiņas un baltās vielas bojājums bija vienādi bieži sastopami gan pacientiem ar miega artērijas stenozi, gan kontroles grupā (Mathiesen et al., 2004). Ir zināms, ka arī sīko asinsvadu slimība ar baltās vielas bojājumu izraisa kognitīvus traucējumus. Baltās vielas bojājums ir saistīts ar informācijas apstrādes ātruma un vadības funkcijas traucējumiem (Prins $\&$ Scheltens, 2015).

Ja jautājums par to, vai miega artērijas stenoze ir saistīta ar kognitīviem traucējumiem vairs nav tik l̦oti apšaubāms, tad jautājums, vai kognitīvā funkcija izmainās pēc revaskularizācijas, vēl joprojām nav skaidrs. Hipotētiskie mehānismi, kā revaskularizācija varētu uzlabot kognitīvo funkciju, ir smadzeņu perfūzijas spiediena palielināšana un mikroembolu iemesla - pangas likvidēšana.

Iepriekšējos sistēmiskos literatūras apskatos, kur analizēti pētījumi, kas veikti pirms 2000. gada, ir norādījumi, ka MEA uzlabo kognitīvo funkciju. Tomēr nedaudzajos sistēmiskajos apskatos, kuros iekḷauti pētījumi pēc 2000. gada, rezultāti nav viennozīmīgi. Vairāku pētījumu metaanalīze ir apgrūtinoša vairāku iemeslu dēḷ - pētîjumi ir ar dažādu metodologiju, atšķirīgiem pielietotiem neiropsihologiskiem testiem, dažādām pacientu 
atlasēm, kontroles grupām, atšķirīgām pielietotām datu apstrādes statistikas metodēm un dažādiem pētījuma norises laikiem. Šo iemeslu dēḷ vairākiem sistēmisko literatūras apskatu autoriem nav izdevies izdarīt secinājumus par to, vai miega artērijas revaskularizācija ietekmē kognitīvo funkciju. (De Rango et al., 2008; Paraskevas et al., 2014; Wang, Mei \& Zhang, 2016) Tikai Antonopoulos et al. veiktajā metaanalīzē par PTA ietekmi uz kognitīvām izmain̄ām secina, ka PTA varētu būt saistīta ar kognitīvās funkcijas uzlabošanos - vispārējās kognitīvās funkcijas, atmiņas un uzmanības/psihomotorā ātruma novērtēšanas domēnos. Uzlabošanās nebija vērojama tādos domēnos kā vadības funkcija, valoda un funkcionālās spējas. Turklāt PTA nebija saistīta ar kognitīvās funkcijas pasliktināšanos, kas ir pretrunā ar faktu, ka periproceduāls CI mikroembolijas dēḷ ir bieži sastopams pacientiem, kuriem veikta miega artērijas PTA (Antonopoulos et al., 2015). Tomēr šai metaanalīzei ir ierobežojumi līdzīgi kā sistēmiskiem apskatiem - dažādi definētas pacientu grupas, nedaudz atšksirīgas stenozes pakāpes, atšķirīgs embolu protekcijas ierīču izmantošanas biežums, dažādi pielietotie testi kognitīvās funkcijas noteikšanai. Tāpēc arī š̄is metaanlīzes autori secina, ka ir nepieciešami RCT ar lielākām pacientu grupām un standartizētiem testiem, lai izdarītu secinājumus par revaskularizācijas ietekmi uz kognitīvo funkciju.

Pašreiz tiek gaidīti rezultāti no tādiem RCT pētījumu kā CREST-2 (Howard et al., 2017), ACTRIS (ACTRIS, 2018), kur tiks analizēti asimptomātiski miega artērijas pacienti, kuriem veiks MEA vai PTA un tie tiks salīdzināti ar pacientiem, kuri saņems tikai labāko medikamentozo terapiju. Šajos pētījumos analizēs ne tikai primāros un sekundāros iznākumus, bet tiks veikta arī kognitīvās funkcijas testēšana (Howard et al., 2017). Tāpēc pašlaik Eiropas Asinsvadu ķirurğijas 2017. gada vadlīnijas piesardzīgi apgalvo - kamēr netiks pierādīta cēlonssakarība starp asimptomātisku nozīmīgu miega artērijas stenozi un kognitīviem traucējumiem, miega artērijas revaskularizācija netiek rekomendēta kā profilaktiska manipulācija kognitīvu traucējumu novēršanai asimptomātiskiem pacientiem ar nozīmīgu miega artērijas stenozi ( III B pierādījumu līmenis) (Naylor et al., 2018).

\subsection{Depresija un nozīmīga miega artērijas stenoze}

Depresijas prevalence cilvēkiem, kuri ir vecāki par 70 gadiem, ir aptuveni 11,19\%. Nav būtiskas atšksirības starp sievietēm $(11,4 \%)$ un vīriešiem (10,2\%) (Steffens \& Fisher, 2009). Deviņdesmito gadu sākumā tika novērota cerebrovaskulāru slimību saistība ar palielinātu depresijas biežumu. Tajos pētījumos konstatēja, ka depresija ir biežāk sastopama tiem cilvēkiem, kuriem ir vaskulāri riska faktori nekā tiem, kuriem to nav.

Vaskulārai depresijai nav vēl izveidota skaidra un precīza definīcija, bet 2016. gadā 
Aizenstein et al. ziņoja, ka vaskulāra depresija ir vēlīnas depresijas specifisks apakštips, kam raksturīga noteikta klīniskā aina (neiropsihiatriskie, neiropsihologiskie simptomi), un tā ir saistīta ar vaskulāriem riska faktoriem un dažādiem cerebrovaskulāriem bojājumiem, ko redz MR kā galvas smadzeņu baltās vielas bojājumu (Aizenstein et al., 2016).

Garastāvokḷu traucējumus, kas attīstās pēc pārciesta CI, Diagnostic and Statistical Manual of Mental Disorders, Fifth Edition (DSM-V) definē kā garastāvokḷa traucējumus ar depresijas simptomiem, smagai depresijai līdzīgu epizodi vai jauktus garastāvokļa traucējumus, kas rodas insulta dēl̦ (American Psychiatric Association, 2013). Depresiju, kas rodas pēc pārciesta CI (PSD) piedzīvo 31\% pacientu piecu gadu laika posmā pēc pārciesta CI (Hackett \& Pickles, 2014). PSD tikai daḷeji tiek uzskatīta par vaskulāras depresijas apakštipu, jo vaskulāra depresija biežāk ir saistīta tieši ar sīko asinsvadu radītu baltās vielas bojājumu. Savukārt PSD parasti ir saistīta ar maǵistrālo asinsvadu izraisītiem galvas smadzeņu asinsrites traucējumiem, izņemot lakunārus CI. Tomēr starp PSD un vaskulāru depresiju ir līdzības. Abiem depresijas veidiem retāk ir sastopama agrīnas depresijas epizode un retāk to novēro citiem pirmās pakāpes radiniekiem. Turklāt abiem šiem depresijas veidiem novēro kognitīvās funkcijas traucējumus vadības funkcijas domēnā. Tieši izmainītās vadības funkcija dēḷ ir funkcionāli traucējumi, kurus savukārt nevēro geriatriskiem pacientiem ar depresiju, kas nav saistīta ar galvas smadzeņu apasiņošanas traucējumiem (Mast et al., 2004).

\subsubsection{Depresijas patoğenēzes mehānisms pacientiem ar simptomātisku miega artērijas stenozi}

Pacientiem ar simptomātisku miega artēriju ir palielināts risks PSD attīstībai. Savstarpējās saistības starp PSD un kognitīviem traucejumiem (īpaši vadības funkcijas domēnā) ir iepriekš labi zināmas (Robinson, 2006). Literatūrā pieejamā informācija liecina, ka ciešas savstarpējās saistības ir starp PSD un CI smagumu, fiziskiem, funkcionāliem un kognitīviem traucējumiem (Kutlubaev \& Hackett, 2014; Hörnsten et al., 2016). Tomēr nav skaidri pierādīts, vai un kādai funkcionālo traucējumu pakāpei ir noteicošā loma PSD attīstībā. Kā arī nav pierādīts, vai ir kādi citi biologiskie faktori metabolītu, hormonālā un strukturālā līmenī, kas ir saistīti ar galvas smadzeņu bojājumu, un kas veicina abos virzienos vērstu saistību starp galvas smadzeņu funkciju traucējumiem un depresiju (Robinson \& Jorge, 2016). Ne tikai depresija ir riska faktors kognitīvu traucējumu attīstībai, bet arī kognitīvi traucējumi pēc CI palielina depresijas sastopamību (Hommel, Carey \& Jaillard, 2015). Turklāt ir pierādīta pārciestas TIL saistīta ar palielinātu depresijas attīstîbas risku - populācijas kohortas pētījumā pierādīja, ka depresijas attīstības risks pēc TIL ir līdzīgs 
depresijas attīstības riskam, kas rodas pēc CI (Luijendijk et al., 2011).

\subsubsection{Depresijas patoğenēzes mehānismi pacientiem ar asimptomātisku miega artērijas stenozi}

Informācija par asimptomātiskas miega artērijas stenozes saistību ar vaskulāras depresijas patoǵenēzes mehānismiem ir ļoti niecīga. Ir atsevišķi ziņojumi par depresiju kā vienīgo vai pirmo asimptomātiskas nozīmīgas miega artērijas stenozes klīnisko izpausmi. Par to norādīja fakts, ka depresijas simptomi izzuda piecu dienu laikā pēc MEA bez specifiskas medikamentozas ārstēšanas (Gressier et al., 2011). Kā tieši vaskulāra saslimšana varētu ietekmēt depresijas attīstību un gaitu nav vēl skaidri zināms. Vaskulāras depresijas simptomi domājams varētu rasties mehāniska savstarpējo neirālo saistību bojājuma, ilgstoša hroniska iekaisuma un hipoperfūzijas izraisītu izmaiņu dēl (Taylor, Aizenstein \& Alexopoulos, 2013).

Pacientiem ar nozīmīgu miega artērijas stenozi, ateroskleroze, kas ir iekaisīga sistēmiska saslimšana, uztur perifēru iekaisumu organismā, tādējādi veicinot proinflamatora stāvokḷa veidošanos CNS. Savukārt paaugstināti perifēro citokīnu (Il-6, Il-1ß, Il-8 un TNF) līmeṇi ir asociēti ar depresijas simptomiem, īpaši vecākiem cilvēkiem (Taylor, Aizenstein \& Alexopoulos, 2013). Depresijas simptomu attīstība hipoperfūzijas dēḷ pacientiem ar nozīmīgu miega artērijas stenozi varētu būt līdzīgi izskaidrojama kā kognitīvu traucējumu attīstība pie asimptomātiskas miega artērijas stenozes. Samazināts CBF traucē šūnu metabolismu, proteīnu sintēzi (Martin, Barad \& Kandel, 2000), kas ir nozīmīgi kognitīvās funkcijas un galvas smadzeñu savstarpējo funkcionālo saistību nodrošināšanā (Debiec, Ledoux \& Nader, 2002). Tāpēc, ja traucētas autoregulācijas rezultātā ievērojamāka CBF samazināšanās var izraisīt išēmiju, tad neliela CBF samazināšanās var ietekmēt kognitīvo funkciju un afektīvos procesus. Baltā viela subkortikāli ir ļoti jūtīga uz šādām izmaiṇām, jo to apasingo terminālās arteriolas ar ierobežotu kollaterāļu skaitu. Šī iemesla dēḷ vecākiem cilvēkiem ar izteiktāku galvas smadzeņu baltās vielas bojājumu ir samazināta perfūzija arī gyrus cinguli rajonā. Šis rajons ir iesaistīts kognitīvās funkcijas un afektīvo procesu nodrošināšanā. Pacientiem ar vēlīnu depresiju izteiktāks perfūzijas deficīts ir laterālā un mediāla prefrontālā garozā, subkortikali un deniņu daivās. (Oda et al., 2003; Dotson et al., 2009) Šo hipotēzi ir izdevies pierādīt ne tikai dzīvnieku modelī (Lee et al., 2015), bet arī divos populāciju tipa pētījumos. Šajos pētîjumos secināja, ka zemāks asins plūsmas ātrums izraisa zemāku galvas smadzenu metabolismu, kas var būt saistīts ar paaugstinātu depresijas simptomu attīstības risku (Direk et al., 2012). Samazināts CBF saistīts ne tikai ar nozīmīgām maǵistrālo artēriju stenozēm, bet arī ar sīko asinsvadu slimību, ko veicina asinsvadu sieniņas elasticitātes samazināšanās 
aterosklerozes dēḷ (van Sloten et al., 2016). Tāpēc pacientiem ar medikamentu rezistentu depresiju un vaskulāriem riska faktoriem būtu nepieciešams veikt miega artērijas doplera ultrasonogrāfiju, lai novērtētu miega artērijas stāvokli, jo tās stenoze varētu būt saistīta ar depresijas attīstību (Coumans \& McGrail, 2000; Gressier et al., 2011).

Pētījumi par depresijas saistību ar kognitīvas funkcijas traucējumiem norāda, ka pacientiem ar vaskulāriem riska faktoriem un sliktāku vadības funkciju kognitīvā stāvokḷa novērtējumā ir lielāks risks depresijas attīstībai (Mast et al., 2004; Sneed \& Culang-Reinlieb, 2011). Savukārt tiem pacientiem, kuriem ir vaskulāri riska faktori un depresija, bet vēl nav ViKD, ir palielināts risks kognitīvo traucējumu attīstībai (Kim et al., 2016; Barnes et al., 2006). Nosakot baltās vielas bojājuma lokalizāciju pacientiem ar vaskulāru depresiju, secināja, ka dziḷās baltās vielas bojājums ir biežāk saistīts ar depresijas simptomu fluktuējošu gaitu, savukārt periventrikulāri baltās vielas bojājumi ir asociēti ar sliktāku vadības funkciju, bet plaši saplūstoši baltās vielas perekḷi - ar kognitīviem traucējumiem un funkcionāliem traucējumiem (Prins \& Scheltens, 2015). Nevaskulāras depresijas klīniskā aina atšķiras no vaskulāras depresijas. Vaskulārai depresijai ir raksturīgi tieši vadības funkcijas traucējumi (energíjas trūkums, subjektīva sajūta, ka pacients jūtas noskumis, anhedonija, psihomotora aizture, palēlinājums, motivācijas trūkums, samazināts domāšanas ātrumu, sliktākas vizuāli telpiskās spējas novērtēšana) nevis nomākts garastāvoklis (Aizenstein et al., 2016).

Jautājumi par hipoperfūzijas un revaskularizācijas ietekmi depresijas simptomu attīstībā vēl joprojām ir neskaidri. Pētījumā par depresijas simptomu izmaiņām pacientiem ar nozīmīgu miega artērijas stenozi pēc PTA secināja, ka depresijas simptomu sastopamība mazinājās pacientiem, kuriem veica PTA (Mlekusch et al., 2006). Savukārt citā pētījumā depresijas simptomi pacientiem pēc endarterektomijas nemazinājās (Carta et al., 2015). Līdz ar to atbilde uz šiem jautājumiem vēl joprojām nav zināma līdz 2024.gadam, kad plānots pabeigt RCT ACTRIS pētījumu, kur viens no sekundāriem mērķiem ir izvērtēt depresijas simptomu izmaiņas pacientiem ar asimptomātisku miega artērijas stenozi pēc tās revaskularizācijas un medikamentozās ārstēšanas (ACTRIS, 2018).

\subsection{Ar veselību saistīta dzīves kvalitāte un nozīmīga miega artērijas stenoze}

\subsubsection{Simptomātiska miega artērijas stenoze}

Insults ir viens no galvenajiem iemesliem ilgtermiņa funkcionāliem ierobežojumiem Eiropā. Ar veselību saistīta dz̄ives kvalitāte (AVSDzK) piecus gadus pēc CI ir sliktāka nekā vispārējā populācijā (par > 1/2 SD zem populācijas normas) (Vlajinac et al., 2013; DeWit et 
al., 2017). Galvenie faktori, kas ietekmē dzīves kvalitāti, ir funkcionālie ierobežojumi un depresija, kas attīstās pēc pārciesta CI (Carod-Artal \& Egido, 2009; White et al., 2016).

\subsubsection{Asimptomātiska miega artērijas stenoze}

Pētījumi par asimptomatisku miega artērijas stenozi un dzīves kvalitāti pieejamā literatūrā nav atrodami. Ir vairāki pētījumi, kas novērtējuši dzīves kvalitāti gan asimptomātiskiem, gan simptomātiskiem miega artērijas stenozes pacientiem kopā pirms un pēc revaskularizācijas.

\subsubsection{Dz̄̄ves kvalitātes izmaiṇas pēc revaskularizācijas}

Salīdzinot dzīves kvalitāti pirms un pēc MEA, tā būtiski nemainās. Ir atsevišksi pētījumi, kas norāda dažu dzīves kvalitātes domēnu uzlabošanos, taču kopumā galvenais secinājums ir tāds, ka dzīves kvalitātes domēnu rādītāji pēc 6 un 12 mēnešiem ir tādi paši kā pirms MEA (Cohen et al., 2011; Stolker et al., 2010). Tas skaidrojams ar to, ka dzives kvalitāte pēc MEA nevar būt labāka kā tā bija pirms revaskularizācijas, jo īpaši asimptomātiskiem pacientiem, kuriem revaskularizācija ir vairāk kā profilaktiska procedūra cerebrovaskulārariska mazināšanai. Salīdzinot dz̄ives kvalitāti pēc MEA un PTA, tad agrīnajā periodā PTA ir pārāka pār MEA fiziskās veselības novērtēšanas domēnos (Cohen et al., 2011; Stolker et al., 2010). Taču šīs atšķirības izzuda pēc 12 mēnešiem. N̦emot vērā, ka dzīves kvalitāte ilgtermiņā ir līdzīga neatkarīgi no pielietotās revaskularizācijas procedūras, tad revaskularizācijas metodes izvēli nosaka citi faktori, piemēram, nepieciešams novērtēt ķirurǵisko risku, kā arī paša pacienta viedokli (Shan et al., 2015; Lal, Meschia, et al., 2017).

Salīdzinot dz̄ives kvalitāti pacientiem ar simptomātisku nozīmīgu (> 70\%) miega artērijas stenozi, kuriem veica MEA, un pacientiem ar < 70\% simptomātisku miega artērijas stenozi, kuriem savukārt MEA netika veikta, secināja, ka dzīves kvalitāte pēc viena gada ir līdzīga abās grupās, izṇemot vispārējās veselības novērtējumu. Lietojot Medical Outcome Survey Short Form 36 dzīves kvalitātes novērtēšanas skalu (SF-36), uzlabojums vispārējā veselības novērtējumā pēc viena gada bija labāks pacientiem, kuriem veica MEA. Lai gan šis ir līdz šim vienīgais pieejamais pêtījums, kas novērtēja dz̄ives kvalitāti simptomātiskiem pacientiem ar miega artērijas stenozi, kuriem neveica operatīvu ārstēšanu, taču šī pētījuma datus jāizvērtē uzmanīgi. Tas skaidrojams ar to, ka medikamentozajā grupā miega artērijas stenoze bija $<70 \%$, kā arī mūsdienu medikamentozā ārstēšana atšķiras no vaskulāru riska faktoru modificēšanas pirms 20 gadiem, kas iespējams varētu izmainīt dzīves kvalitātes 
novērtējumu (Martin et al., 1998).

\subsubsection{Dzīves kvalitāte pacientiem ar depresiju, kognitīviem traucējumiem}

Literatūras apskatā, kur apkopoti šķērsgriezuma tipa pētījumi un vairāki populāciju novērošanas pētījumi ir pārliecinoši norādījumi par savstarpējo saistību depresijai ar sliktāku dzīves kvalitāti vecākiem cilvēkiem, neskatoties uz to, ka tika pielietotas dažādas skalas (Sivertsen et al., 2015). Izvērtējot dzīves kvalitāti pacientiem ar vieglu kognitīvu deficītu, arī šai cilvēku grupai dzīves kvalitātes rādītāji ir zemāki, īpaši tiem, kuriem ir atmiņas traucējumi (Maki et al., 2014) nekā cilvēkiem bez kognitīvās funkcijas ierobežojumiem (Bárrios et al., 2013; Teng, Tassniyom \& Lu, 2012). 


\section{MATERIĀLS UN METODES}

\subsection{Pacientu grupas un atlase}

Pētījumā iekḷauti pacienti ar nozīmīgu iekšèjās miega artērijas stenozi ( $\geq 70 \%$ stenoze), kuri tika izmeklēti Paula Stradiṇa klīniskās universitātes slimnīcas (PSKUS) Insulta profilakses kabinetā vai stacionēti PSKUS Asinsvadu ķirurğijas centrā, Latvijas Kardiologijas centrā un Neirolog̣ijas klīnikā laika posmā no 2015. gada marta līdz 2017.gada oktobrim, un atbilda visiem pētījuma iekḷaušanas kritērijiem.

\section{Ieklaušanas kritêriji:}

- pacients vecāks par 18 gadiem;

- pacientam diagnosticēta simptomātiska vai asimptomātiska nozīmīga iekšējās miega artērijas stenoze. Miega artērijas stenozi uzskatīja par nozīmīgu, ja datortomogrāfijas angiogrāfijā galvas un kakla asinsvadiem tās lūmena sašaurinājums ekstrakraniāli bija 70-99\% pēc NASCET kritērijiem (North American Symptomatic Carotid Endarterectomy Trial Colaborators, 1991). Miega artērijas stenozi uzskatīja par simptomātisku, ja pēdējo 6 mēnešu laikā pacients bija klīniski pārciestis CI, TIL vai amaurosis fugax tās apasiņošanas baseinā, ņemot vērā ECST kritērijus (Warlow, 1991). Miega artēriju uzskatīja par asimptomātisku, ja pēdējo 6 mēnešu laikā nebija izraisījusi klīnisku CI, TIL vai amaurosis fugax atbilstoši ACST kritērijiem (Halliday, Thomas and Mansfiel, 1994);

- pacientam nav nozīmīgs neiroloǵisks defekts pēc pārciesta CI (iekḷaušanas brīdī Nacionālā veselības institūta insulta skalas (National Institute of Health Stroke Scale $($ NIHSS)) $\leq 3$ punktiem, modificētā Rankina skala (mRS) 0-II pakāpe (Fischer et al., 2010));

- ir indikācijas miega artērijas endarterektomijai vai endovaskulārai ārstēšanai;

- pacients piekritis piedalīties pētījumā pirmo gadu pēc iekļaušanas tajā.

Izslēgšanas kritēriji:

- pacients pārcietis CI un ir novērojams izteikts neirologiskss defekts (NIHSS $\geq 4$, mRS III-IV pakāpe);

- CTA diagnosticēta miega artērijas stenoze ar < 70\% lūmena sašaurinājumu;

- pacientam ir jebkāda cita progresējoša neirologiska saslimšana (galvas smadzeņu audzējs, multiplā skleroze, Alcheimera demence);

- pacientam ir zināma depresija vai arī viņš lieto antidepresantus jebkādu citu saslimšanu ārstēšanai;

- pacients nav ieradies ne uz vienu turpmāko novērošanas vizīti dzīvesvietas attāluma dēl vai pilnībā atteicies no turpmākas dalības pētījumā, nepaskaidrojot iemeslu. 
Sākotnēji pētījumā iekļauti 237 pacienti ar nozīmīgu miega artērijas stenozi, no kuriem 24 pacienti tika izslēgti. Izslēgšanas iemesli: nevēlējās tomēr pēc revaskularizācijas turpināt dalību pētījumā $(n=16)$, stenoze $<70 \%(n=4)$, miega artērijas stenozes iemesls nebija ateroskleroze $(n=2)$, lietoja antidepresantusvai citus medikamentus, kas varētu ietekmēt rezultātu $(\mathrm{n}=2)$. Dalību pētījumā uzsāka 213 pacienti.

\subsection{Pētījuma norise}

Lēmumu par nozīmīgas miega artērijas stenozes ārstēšanas veidu pieņēma ārstējošais ārsts un pacients neatkarīgi no pētījuma. Pacienti tika iedalīti 3 grupās atkarībā no nozīmīgas miega artērijas stenozes ārstēšanas veida:

1) pacienti, kuriem bija veikta iekšējās miega artērijas endarterektomija (MEA+MT; $\mathrm{n}=159)$;

2) pacienti, kuriem bija veikta iekšējās miega artērijas perkutāna translumināla angioplastija un stentēšana (PTA+MT; $\mathrm{n}=29)$;

3) pacienti ar nozīmīgu iekšējās miega artērijas stenozi, kuri paši atteicās no miega artērijas endarterektomijas; un/vai plānoja miega artērijas stenozes endovaskulāru ārstēšanu, bet tā netika veikta no pētījuma neatkarīgu iemeslu dēl tā norises laikā - medikamentozās terapijas grupa (MT; $\mathrm{n}=25)$.

Visiem pacientiem bija rekomendēta optimāla medikamentozā terapija: antiagreganti, statīni, lai sasniegtu ZBL līmeni $\leq 2,6$ mmol/1, antihipertensīva terapija mērķa asinsspiediena sasniegšanai (< 140/90 mmHg), stingra glikēmijas kontrole CD pacientiem, veikta izglītošana par smēķēšanas kaitīgumu un nepieciešamību to atmest, kā arī izglītošana par nepieciešamību samazināt svaru, nodarboties ar regulārām fiziskām aktivitātēm un lietot sabalansētu uzturu.

Pacienti tika izmeklēti 1-3 dienas pirms plānotās miega artērijas revaskularizācijas. Pacienti, kuri atteicās no miega artērijas revaskularizācijas, tika izmeklēti iepriekšējā dienā pirms izrakstī̌̌anas no slimnīcas. Savukārt pacienti, kuri griezās PSKUS Insulta profilakses kabinetā, tika izmeklēti ārsta apmeklējuma dienā.

Pētījumā katram pacientam bija plānotas 3 vizītes:

- pirmā vizīte (V1) - pirms paredzamās revaskularizācijas vai diagnosticēšanas/ konsultēšanas brīdī;

- otrā vizīte (V2) - 6 mēnešus (180 dienas \pm 14 dienas) pēc pirmās vizìtes;

- trešā vizīte (V3) - 12 mēnešus (365 dienas \pm 14 dienas) pēc pirmās vizītes.

Sešu un 12 mēnešu novērošanas laiks bija noteikts, lai izvērtētu ilgtermiņa iznākuma rezultātus pacientiem ar nozīmīgu miega artērijas stenozi ar vai bez revaskularizācijas. 
Pirmajā vizîtē (V1) tika iegūti pacienta demogrāfiskie dati (dzimums, vecums, izglītības līmenis), antropometriskiedati (augums, svars), dati par smēķěšanu, dati par blakussaslimšanām (cerebrovaskulāri notikumi anamnēzē, koronāra sirds slimība, arteriāla hipertensija, hroniska sirds mazspēja (HSM), mirdzaritmija (MA), cukura diabēts, perifēro asinsvadu slimība, hroniska nieru slimība (HNS), locītavu sāpes, vairogdziedzera hipo- vai hiper-funkcija, nopietni redzes traucējumi, hroniskas plaušu slimības, audzējs anamnēzē), kā arī dati par lietotajiem medikamentiem strukturētas intervijas veidā.

Par smēķētājiem uzskatīti pacienti, kuri smēķēja vai bija atmetuši smēķēšanu mazāk kā 5 gadus pirms iekḷaušanas pētījumā. Koronāru sirds slimību grupā iekḷauta slodzes stenokardijaun/vai vecs MI, un/vai aortokoronāra šuntēšana anamnēzē. AH par kontrolētu uzskatīja, ja pacientam, lietojot medikamentus, asinsspiediens bija $<140 / 90 \mathrm{mmHg}$. Par CD slimniekiem tika uzskatīti pacienti, kuriem anamnēzē bija 1. vai 2. tipa CD, vai pacients pētījumā laikā lietoja hipoglikemizējošus medikamentus, kā arī ja HbA1c bija $\geq 6,5 \%$. Par kontrolētu CD tika uzskatîts, ja HbA1c bija $\leq 7 \%$. PAS pacientam dokumentēja tad, ja klīniski izpaudās claudicatio intermittens vai arī tad, ja pacientam anamnēzē bija veikta perifēro artēriju revaskularizācija aterosklerozes dēl̦.

Pacienta neirologiskā stāvokḷa izvērtēšanā izmantoja NIHSS latviešu valodas versiju. Pacienta funkcionālās nespējas pakāpes noteikšanai izmantoja mRS (Latvijas Neirologu Biedrība et al., 2013). Visus iegūtos datus darba autore dokomentēja standartizētā pētījuma anketā, kas atspogulıota 2. pielikumā.

Pēc pacienta vispārējās un neirologiskās izmeklēšanas tika pārbaudīta viṇa kognitīvā funkcija un lūgts aizpildīt depresijas un AVSDzK novērtēšanas anketas (3., 4. un 5. pielikums).

Informācija par miega artērijas stenozes revaskularizācijas pielietoto metodi (endarterektomijas vai perkutānās transluminālās angioplastijas procedūras norisi) iegūta pēc pacienta izrakstīšanas no slimnīcas, ko arī dokomentēja standartizētā pêtījuma anketā, kas atspoguļota 2. pielikumā.

Uz pētījuma otro (V2, pēc 6 mēnešiem) un trešo (V3, pēc 12 mēnešiem) vizīti darba autore pētījuma dalībniekus aicināja telefoniski. Katras vizītes laikā tika novērtēts pacienta vispārējais stāvoklis, neiroloǵiskais stāvoklis, iegūta informācija no paša pacienta par regulāri lietotajiem medikamentiem, kā arī pārbaudīta pacienta kognitīvā funkcija un lūgts aizpildīt depresijas un AVSDzK novērtēšanas anketas. Turklāt otrajā un trešajā vizītē katram pacientam tika veikta kakla asinsvadu dupleksultrasonogrāfija, lai noteiktu miega artērijas intima media slāṇa biezumu un restenozes pakāpi. Visas duplekss USG veica viens sertificēts neirosonologs, kuram informācija par pacienta miega artērijas ārstēšanas veidu un veiktajiem 
testu rezultātiem nebija pieejama. Visas duplekss USG veiktas ar Philips iE33, ar lineāro zondifrekvences robežās no 5 līdz $12 \mathrm{MHz}$. Mērot plūsmas ātrumu ar doplerogrāfijas metodi, plūsmas virziena lenķis nepārsniedza $60^{\circ}$ leņķi (de Bray \& Glatt, 1995; Stein et al., 2008).

Tā kā pētījums ilga vienu gadu, tika analizēti arī primārie un sekundārie nelabvēlīgie iznākumi. Par primāru nelabvēlīgu iznākumu uzskatīja, ja pacienam ar nozīmīgu miega artērijas stenozi 30 dienu laikā pēc revaskularizācijas vai pēc iekḷaušanas pētījumā attīstījās cerebrovaskulārs notikums (CI, TIL, amaurosis fugax), miokarda infarkts, perioperatīva intracerebrāla hematoma (ICH) vai exitus letalis. Par sekundāru nelabvēlīgu iznākumu uzskatīja, ja gada laikā kopš iekļaušanas pētījumā, izṇemot pirmās 30 dienas, pacientam novēroja cerebrovaskulāru notikumu (CI, TIL, amaurosis fugax), akūtu koronāru notikumu vai exitus letalis, kuru dēl pacients nevarēja ierasties uz atkārtotu vizīti.

\subsection{Pētījumā pielietoto mērinstrumentu raksturojums}

\subsubsection{Kognitīvās funkcijas novērtēšana}

Lai noteiktu kognitīvās funkcijas traucējumus, klīniskajā praksē būtu jāveic detalizēti neiropsihologiskie testi, kas aizņem vairākas stundas. Turklāt tos var veikt un interpretēttikai apmācīts speciālists - neiropsihologs. Nereti ikdienā un pētījumos pielieto īsākus skrīninga instrumentus vai testus kognitīvās funkcijas novērtēšanai. Testos, kas novērtē kognitīvo funkciju pacientiem ar cerebrovaskulāriem traucējumiem, ir jāiekḷauj un jāizvērtē sekojoši kognitīvās funkcijas domēni: uzmanība un informācijas apstrādes ātrums, frontālā vadības funkcija, mācīšanās un atmiņa, valoda, vizuālā - konstrukcijas uztvere, praksijas - gnozijas - ķermeņa shēmas uztvere un sociālā kognitīvā funkcija (emociju un sociālo norādījumu atpazī̌sana, atbilstoša sociāla uzvedība, empātija) (Sachdev et al., 2014).

Mini-mentālā stāvokḷa novērtēšanas (MMSE) un Monreālas kognitīvās funkcijas novērtēšanas (Montreal Cognitive Assessment Scale (MoCA)) skalas plaši izmanto kognitīvās funkcijas izvērtēšanā un viegla kognitīva deficīta diagnosticēšanā. MMSE skrīninga tests ir plaši izmantots kognitīvās funkcijas novērtēšanā pie dažādām saslimšanām. Sākotnēji to izveidoja, lai diagnosticētu Alcheimera slimību, tāpēc tā ir vairāk sensitīva valodas un atmiņas funkcijas traucējumu identificēšanai, bet ne frontālās vadības funkcijas novērtēšanai. Tieši frontālās vadības funkcijas traucējumi ir vieni no galvenajiem vaskulāra kognitīva deficīta pazīmēm. Savukārt MoCA skala ļauj izvērtēt vairākus frontālās vadības funkcijas aspektus, tāpēc to iesaka izmantot kā skrīninga instrumentu vaskulāra kognitīva deficīta noteikšanai (Nasreddine et al., 2005; Pendlebury et al., 2012; Bocti et al., 2013; Cumming et al., 2013; 
Koski, 2013), it sevišķi populācijā, kas vecāka par 60 gadiem (Ciesielska et al., 2016). MoCA ir adaptēta no vairākiem neiropsiholoğiskiem testiem: Trail Making B uzdevuma, fonēmiska valodas raituma uzdevuma (phonemic fluency task) un verbālas divu vien̄̄bu vispārināšanas (2-item verbal abstraction task). Verbālā atmiņa ietver gan tūlītēju atsaukšanu atmiņā (uzmanības novērtēšanai), gan attālinātu atsaukšanu atmiņā (Dichgans \& Leys, 2017). Lam et al. ziņo par ciešāku neiropsihologisko testu korelāciju ar MoCA nekā ar MMSE testiem atmiṇas, frontālās vadības funkcijas, vizuāli telpiskās uztveres domēnos (Lam et al., 2013).

Šajā pētījumā promocijas darba autore izmantoja MoCA skalu gan latviešu, gan krievu valodās, lai novērtētu pacientu kognitīvo funkciju dzimtajā valodā atbilstoši MoCA testa autoru aizpild̄̄šanas un novērtēšanas instrukcijām (Nasreddine Ziad, 2015). MoCA skala sastāv no 7 daḷām, kas ļauj novērtēt 7 kognitīvās funkcijas domēnus: frontālās vadības funkcijas un vizuāli telpiskās uztveres spējas (pamīšus secīgu burtu un ciparu savienošana (alternating trail making); kuba pārzīmēšana; pulksteņa zīmēšana) - 5 punkti; nosaukšana (lauva, degunradzis, kamielis) - 3 punkti; uzman̄iba (ciparu atkārtošana tiešā un pretējā secībā; modrības pārbaude, dzirdot burtu A; cipara 7 atņemšana no 100 un attiecīgi tālāk no sava iegūtā rezultāta (substracting 7s from 100)) - 6 punkti; valoda (teikumu atkārtošana; valodas raitums - dažādu vārdu nosaukšana, kas sākas ar vienu burtu) - 3 punkti; vispārināšana (līdzības noteikšana starp vārdiem vilciens un velosipēds, pulkstenis un lineāls) - 2 punkti; atmiņa (iepriekš nosaukto vārdu atsaukšana atmiņā) - 5 punkti; orientācija (laikā un telpā) - 6 punkti. Papildus punkts tiek pieškirts, ja respondenta izglīitiba ir 12 vai mazāk skolas gadu (Nasreddine et al., 2005). MoCA testa aizpildīšana aizņem aptuveni 10 minūtes, tās kopējais punktu skaits var būt no 0 līdz 30. Ja MoCA kopējais punktu skaits ir 26 vai vairāk, tad kognitīvā funkcija tiek uzskatīta par normālu. Pētījumā izmantotie MoCA testi latviešu un krievu valodās aplūkojami 3. pielikumā.

\subsubsection{Depresijas simptomu novērtēšana}

Depresijas simptomu noteikšanai tika izmantota Patient Health Questionnaire (PHQ-9) - jautājumu anketa, ko aizpilda pats pacients, atbildot uz 9 jautājumiem par pēdējām 2 nedēḷām. Jautājumi ir atvasināti no DSM-IV depresijas kritērijiem. Tos pacientam ir viegli izlasīt un saprast, jo tie atbilst Likerta skalas principam, kā arī aizpildīšana aizņem aptuveni minūti. Kopējais 9 jautājumu punktu skaits var būt no 0 līdz 27. Katrs jautājums var tikt novērtēts no 0 līdz 3 punktiem: atbildi "nemaz" vērtē kā 0 punkti, "dažas dienas" - 1 punkts, "vairāk par nedēḷu" - 2 punkti, savukārt atbilde "gandrīz katru dienu" - 3 punkti (PHQ-9 
Instruction Manual, 2015). Saskaitot punktus, iespējams noteikt ne tikai depresijas simptomu esamību, bet arī smaguma pakāpi - rekurenti depresīvi traucējumi vai subklīniska depresija. Ja punktu skaits ir 0-4, tad var uzskatīt, ka nav depresijas simptomu vai arī tie ir minimāli; ja 5-9, tad var domāt, ka pacientam ir viegli depresijas simptomi, bet medikamentoza terapija vēl nav nepieciešama; ja 10-14 punkti, tad depresijas simptomi ir vidēji izteikti, nepieciešams uzsākt ārstēšanu ar vai bez medikamentozās terapijas; ja punktu skaits 15-19, tad depresija ir uzskatāma par vidēji smagu, kad ir nepieciešama aktīva farmakoterapija ar vai bez psihoterapijas; savukārt, ja punktu skaits $>20$, tad depresijas simptomi ir uzskatāmi par smagiem, kad nepieciešama neatliekama kompleksas terapijas uzsākšana (Kroenke \& Spitzer, 2002). Ne tikai kopējais punktu skaits ir svarīgs depresijas simptomu smaguma pakāpes noteikšanā, bet arī tas, kā un uz kuriem jautājumiem pacients ir atbildējis, lai varētu PHQ-9 izmantot kā depresijas skrīninga instrumentu. Par rekurentiem depresīviem traucējumiem var domāt, ja vismaz uz pieciem jautājumiem pacients ir atbildējis "vairāk par nedēḷ" vai "gandrīz katru dienu", kur vienam no pieciem apstiprinošiem jautājumiem ir jābūt vai nu pirmajam vai otrajam jautājumam. Savukārt par subklīnisku depresiju var domāt, ja pacients ir atbildējis uz 2 līdz 4 jautājumiem ar "vairāk par nedēlu" vai "gandrīz katru dienu", kur vienam no 2 līdz 4 jautājumiem ir jābūt vai nu pirmajam vai otrajam apstiprinošajam jautājumam. Ja pacients atbildējis 9. jautājumā apstiprinoši, tad tas tiek uzskatīts kā depresijas simptoms (PHQ-9 Instruction Manual, 2015). Veicot PHQ-9 skalas validāciju, tās autori pierādīja, ka par rekurentiem depresijas traucējumiem var domāt, ja kopējais PHQ-9 punktu skaits ir $\geq 10$ ( $88 \%$ sensitivitāte un $88 \%$ specifitāte) (Kroenke, Spitzer \& Williams, 2001).

PHQ-9 kā skrīninga instruments depresijas simptomu un to pakāpju noteikšanai tika izvēlēts, jo tas ir pielīdzināms citām depresijas noteikšanas skalām (Kroenke, Spitzer \& Williams, 2001; Kung et al., 2013), bet tas aizņem mazāk laika, nezaudējot specifitāti un sensitivitāti (Berwick et al., 1991). Turklāt šis tests ir brīvi pieejams (Williams \& Kroenke, 2010). Turklāt šī skala bieži tiek izmantota pētījumos par vaskulāru depresiju (Beutel et al., 2014) un depresiju, kas attīstās pēc pārciesta CI (Williams et al., 2005; De Man-Van Ginkel et al., 2012), jo PHQ-9 jautājumi atbilst depresijas kritērijiem (Robinson \& Jorge, 2016).

Šajā pētījumā izmantotas PHQ-9 anketas latviešu un krievu valodās atbilstoši PHQ-9 testa autoru sniegtajām instrukcijām (PHQ-9 Instruction Manual, 2015), kas iepriekš validētas Latvijā pirmārajā veselības aprūpē (Vrublevska, Trapencieris \& Rancans, 2018). Pacients testu aizpildīja klusā telpā, nepieciešamības gadījumā neskaidrie jautājumi tika paskaidroti. Pētījumā izmantotās PHQ-9 anketas latviešu un krievu valodās aplūkojamas 4. pielikumā. 


\subsubsection{Ar veselību saistītās dzīves kvalitātes novērtējums}

Lai novērtētu ar veselību saistītu dzīves kvalitāti, izmanto mērījumus jeb anketas, kur paši pacienti novērtē iznākumu (patient reported outcome measures (PROM)). Tās ir jautājumu anketas, ko aizpilda pats pacients, atbildot uz jautājumiem par pacienta veselību un viņa ikdienas aktivitātēm. Šādā veidā iegūtā informācija nodrošina iespēju izvērtēt slimības un tās ārstēšanas metožu ietekmi uz veselību un ar to saistīto dzīves kvalitāti no pacienta perspektīvas jeb skatu punkta (U.S. Department of Health and Human Services FDA Center for Drug Evaluation and Research, 2006). Essat M. et al. veiktajā sistēmiskajā literatūras apskatā un metaanalīzē tika norādīts, ka šobrīd nav pietiekošu pierādījumu par kādas PROM skalas pārākumu pār citām, ko būtu jāpielieto pacientiem, kuriem veikta miega artērijas revaskularizācija (Essat et al., 2018). Tā kā nav vienota viedokḷa, tad SF-36 anketa ir viena no plašāk pielietotiem dzīves kvalitātes mērījuma instrumentiem asinsvadu ķirurğijāa ko izmanto dz̄ives kvalitātes pētījumos (Shan et al., 2015).

SF-36 ir genērisks dzīves kvalitātes mērījuma instruments, kas mēra dzīves kvalitāti astoņos atšķirīgos veselības domēnos un ļauj salīdzināt ar kontroles vai citām populācijām, vai citiem veselības stāvokḷiem. SF-36 sastāv no 11 pamatjautājumiem un 25 apakšjautājumiem (Ware and Sherbourne, 1992). SF-36 validācijas un vairāk kā 70 valstu valodu tulkošanas procesa laikā tā tika uzlabota. Tika optimizēta SF-36 anketas valoda un atbilžu formulējumi, tādējādi tika radīta SF-36 uzlabotā versija Medical Outcome Survey Short Form 36 version 2 (SF-36v2) (Optum, 2008b). Lai gan SF-36v2 ir ļoti līdzīga SF-36, tomēr jaunajai versijai ir vairākas priekšrocības: uzlabota precizitāte tādu domēnu novērtējumā kā fiziskā veselības stāvokḷa ietekme uz iesaistīšanos darba un ikdienas aktivitātēs un emocionālais stāvoklis; uzlabots jautājumu formulējums; lietotājam draudzīgāks formāts - atbilžu varianti labāk saprotami (Optum, 2008a). SF-36v2 anketa novērtē ar veselību saistītu dzīves kvalitāti pēdējo 4 nedēḷu laikā sekojošos domēnos (Ware et al., 2008):

1) fiziskās funkcionēšanas spējas (physical functioning - PF) - atspoguḷo fizisko aktivitāšu ierobežojuma veidu un līmeni gan fiziski grūtākās, gan ikdienas aktivitātēs. Zemi rādītāji norāda par izteiktu visa veida fizisko aktivitāšu ierobežojumiem, ieskaitot pašaprūpi, tas ir, mazgāšanos vai gẹerbšanos. Savukārt augstāki rādītāji atspoguḷo spēju veikt dažāda veida fiziskās aktivitātes bez veselības stāvokḷa izraisīta ierobežojuma;

2) fiziskā veselības stāvokḷa ietekme uz iesaistǐšanos darba un citās ikdienas aktivitātēs (role limitations due to physical problems - RP) - norāda par fiziskās veselības radītiem ierobežojumiem veicot darba pienākumus vai citas ikdienas aktivitātes, to radīto laika patēriņu un grūtības pakāpi. Zemi rādītāji norāda par grūtībām veikt darbus vai ikdienas 
aktivitātes, kas radušās fiziskās veselības problēmu dēlı. Augsti rādītāji - nav grūtības veikt darbus un ikdienas aktivitātes fiziskās veselības problēmu dēḷ;

3) sāpes (bodily pain - BP) - atspoguḷo sāpju intensitāti un to izraisīto ietekmi uz ikdienas aktivitātēm. Zemi rādītāji norāda par izteiktām sāpēm, kas ietekmē ikdienas aktivitātes, savukārt augsti rādītāji - nav izteiktu sāpju, kas ietekmētu ikdienas aktivitātes;

4) vispārējais veselības stāvoklis (general health - GH) - atspoguḷo pacienta viedokli par savu veselības stāvokli kopumā. Zemi rādītāji norāda, ka veselības pašvērtējums ir zems un pacients uzskata, ka veselība pasliktināsies, savukārt augsti - veselības pašvērtējums ir labs;

5) vitalitāte (vitality - VT) - novērtē subjektīvu enerǵijas un noguruma pakāpi. Zemi rādītāji norāda, ka pacients jūtas lielāko dalıu laika noguris un iztukšots. Savukārt augsti rādītāji - pacients lielāko vai visu laiku jūtas enerǵijas pilns;

6) sociālā funkcija (social functioning - SF) - atspoguḷo kvantitatīvus un kvalitatīvus ierobežojumus iesaistīties ikdienas sociālās aktivitātēs fiziskās un psihiskās veselības stāvokḷa dēḷ. Zemi rādītāji liecina, ka pacientam ir ierobežota iesaistǐšanās ikdienas sociālās aktivitātēs fiziskās un psihiskās veselības problēmu dēḷ. Toties augsti rādītāji - pacients iesaistās brīvi ikdienas sociālās aktivitātēs;

7) emocionālais stāvoklis (role limitations due to emotional problems - RE) - norāda psihiskās veselības radītus ierobežojumus - to radīto laika patēriņu, apjomu un rūpīgumu, veicot darba vai ikdienas pienākumus. Zemi rādītāji norāda par grūtībām veikt darbus vai ikdienas aktivitātes, kas radušās psihiskas veselības problēmu dēḷ. Augsti rādītāji - nav grūtības veikt darbus un ikdienas aktivitātes psihiskās veselības problēmu dẹḷ;

8) psihiskā veselība (mental health - MH) - atspoguḷo 4 galvenās psihiskās veselības dimensijas - trauksmi, depresiju, uzvedības/emocionālās kontroles zudumu un emocionālu labsajūtu. Zemi rādītāji norāda par trauksmes un nomāktības sajūtu, savukārt augsti - par miera, laimes un emocionālo labsajūtu lielākajā laika daļā.

Bez galvenajiem astoņiem ar veselību saistītās dzīves kvalitātes domēniem, SF-36v2 ļauj novērtēt arī fiziskās veselības vispārējo stāvokli (physical component summary - PCS) un psihiskās veselības vispārējo stāvokli (mental component summary - MCS). Šie abi rādītāji ir astoņu veselības domēnu apkopojums divos galvenajos veselības rādītājos - fiziskās un psihiskās veselības novērtējumā. Zemi PCS rādītāji liecina par fiziskās aktivitātes ierobežojumiem, kas radušies fiziskās veselības problēmu dēḷ, par izteiktām sāpēm un zemu vispārējās veselības vērtējumu. Toties augsti PCS liecina par mazizteiktiem vai neesošiem fiziskās aktivitātes ierobežojumiem, kas radušies fiziskās veselības problēmu dēḷ, par augstu vai pietiekošu enerǵijas daudzumu un labu vispārējās veselības pašvērtējumu. Zemi MCS 
rādītāji liecina par biežiem psihologiiskiem traucējumiem, fizisko un sociālo aktivitāšu ierobežojumiem, kas radušies psihiskās veselības traucējumu dēḷ un zemu vispārējās veselības pašvērtējumu. Augsti MCS - par labu psiholoǵisko pašsajūtu, labu vispārējās veselības pašvērtējumu un retiem vai neesošiem fizisko un sociālo aktivitāšu ierobežojumiem, kas radušies psihiskās veselības problēmu dēl (Ware et al., 2008).

Šajā pētījumā ASDzK pacientiem ar nozīmīgu miega artērijas stenozi tika novērtēta, izmantojot SF-36v2 latviešu un krievu valodas variantus (Optum, 2015). Papīra formāta anketu pacienti aizpildīja patstāvīgi vidēji 10 minūšu laikā, nepieciešamības gadījumā tika paskaidrots neskaidrais jautājums. Pēc tam anketas rezultāti tika ievadīti Quality Metric Health Outcomes ${ }^{T M}$ ScoringSoftware 4.5. programmā, kur tie tika transformēti: no 0 (zemākā iespējamā vērtība, kas norāda par sliktāko iespējamo veselības stāvokḷa novērtējumu) līdz 100 (augstākā iespējamā vērtība, kas norāda par labāko iespējamo veselības stāvokḷa novērtējumu). Aprēksinātās SF-36v2 domēnu vērtības ir standartizētas ar populācijā sastopamo vidējo vērtību 50 un standarta deviāciju 10 (Saris-Baglama et al., 2011). Ievadīto datu kvalitāte atbilda SF-36v2 anketas autoru norādītajām normām: SF-36v2 anketas domēnu (scale reliability and homogeneity) iekšējās saskaņotības Cronbach's alpha rādītāji bija visos domēnosno 0,8 līdz 0,94, iznemot vispārējā veselības stāvokḷa (GH) novērtējuma domēnā, kur Cronbach's alpha rādītājs bija 0,7. Aț̣auja izmantot šo anketu tika iegūta no OptuminsightLifeScience, atļaujas licences numurs QM028606. Anketas latviešu un krievu valodās pievienotas 5.pielikumā.

\subsection{Datu statistiskā analīze}

Pētījuma datu apstrāde un statistiskā analīze veikta pēc medicīniskās statistikas metodēm, izmantojot aprakstošo un analītisko statistiku. Aprakstošās statistikas metode tika izmantota, lai novērtētu pētāmo populāciju demogrāfiskos un klīniskos rādītājus. Kvalitatīvie jeb kategoriskie mainīgie tika raksturoti kā skaits $(\mathrm{N})$ un procentuāla proporcija. Kvantitatīvie rādītāji tika aprakstīti ar vidējo aritmētisko (M) un standartnovirzes (SD) vērtībām. Gadījumos, kad pētāmās grupas neatbilda normālsadalījumam, tika aprēķināta mediāna (Me) un strapkvartilu izkliedes amplitūdas (IQR; Interquartile range). Lai salīdzinātu kategoriskos mainīgos starp 2 pētāmām grupām, tika izmantots Pīrsona $\chi^{2}$ (Pearson's Chi-squared) vai Fišera (Fisher) eksaktais tests atbilstoši šo testu lietošanas nosacījumiem. Lai noteiktu kvantitatīvo main̄̄go atšķirības starp vairāk nekā 2 grupām, izmantoja Kruskal-Wallis vai vienfaktora dispersijas ANOVA (analysis of variance) testus. Lai noteiktu atšķirības starp 3 atkarīgo izlašu kvantitatīvajiem rādītājiem, tika izmantots Friedman's tests. Savukārt lai 
novērtētu 2 atkarīgo izlašu atšķirības kvantitatīviem rādītājiem, izmantoja Vilkoksona (Wilcoxon signed rank) testu, bet kategoriskiem rādītājiem - Maknēmara (McNemar) testu. Gadījumos, kur salīdzinot 3 pētāmās grupas, konstatēja atšksirību, tika veikta post-hoc analīze. Post-hoc analīzē tika salīdzināta katra grupa savstarpēji, lai noteiktu starp kurām 2 no trim pētāmām grupām ir š̄ atšķirība.

Lai novērtētu Pīrsona $\chi^{2}$ vai Fišera eksaktā testa statistikā efekta lielumu, tika aprēķināta Krāmera V (Cramer's V) vērtība. Statistiskā efekta novērtēšanai tika izmantots šāds iedalījums: $0,1-0,3=$ mazs; $0,3-0,5=$ vidējs; $>0,5=$ liels. Lai novērtētu KruskalWallis un ANOVA testu statistisko efekta lielumu, tika aprēķināts $\eta^{2}$ (partial eta squared). Statistiskā efekta lieluma novērtēšanai tika izmantots šāds iedalījums: $\leq 0,01=$ mazs; $0,06=$ vidējs; $\geq 0,14=$ liels. Savukārt Cohen's $d$ statistiskā efekta lieluma novērtēšanai tika izmantots šāds iedalījums: 0,2 = mazs; 0,5 = vidējs; $>0,8=$ liels. Efekta lielums Friedman's testam tika izteikts ar Kendall's coefficient of concordance (Kendall's W): 0,1 = mazs; $0,3=$ vidējs; $0,5=$ liels. Statistiskā efekta lielums Wilcoxon rank testam tika noteikts ar $r$ koeficientu, bet McNemar testam - ar $g$ koeficientu. Mazs efekta lielums $r$ koeficientam ir 0,1 bet $g$ koeficientam 0,05 ; vidējs lielums $r$ koeficientam $-0,3$, bet $g$ koeficientam $-0,15$; liels $-r$ koeficientam $-0,5$, bet $g$ koeficientam $-0,25$.

Lai novērtētu kognitīvās funkcijas izmaiņas novērošanas periodā (6 un 12 mēnešos), tika aprēķināta paz̄imju relatīvā izteiktība. Kopējās kognitīvās funkcijas relatīvā izteiktības vērtỉba pēc 6 mēnešiem tika aprēķināta pēc sekojošas formulas: no 6 mēnešu kopējā MoCA punktu skaita atṇemot sākotnējo kopējo MoCA punktu skaitu un šo starpību izdalot ar sākotnējo kopējo MoCA punktu skaitu ((V2 - V1)/V1). Līdzīgi tika aprēķināt kopējās kognitīvās funkcijas relatīvā izteiktības vērtība pēc 12 mēnešiem: ((V3 - V1)/V1). AVSDzK novērtēšanā analizētas SF-36v2 vidējās vērtības (SD) atbilstoši Shan et al. rekomendācijām (Shan et al., 2015). Lai noteiktu dažādu klīnisko raksturlielumu saistību ar AVSDzK izmain̄ām gada laikā katrā grupā, tika aprēķināta katra SF-36v2 domēna vidējās vērtības starpība pēc formulas: (V3 - V1). SF-36v2 relatīvo izteiktības vērtību ((V3 - V1)/V1) nevarēja aprēķināt, jo dažiem pacientiem bija sastopama nulles vērtība kādā no domēniem.

Atbilstoši nosacījumiem divu pazīmju saistības analīzei tika izmatota Spīrmena (Spearman's) korelāciju analīze (apzīmē ar $\mathrm{r}_{\mathrm{s}}$ ). Pētījumā pieņemta šāda korelācijas ciešuma klasifikācija atkarībā no korelācijas koeficienta $r_{s}$ lieluma: korelācija ir vāja, ja $r_{s} \leq 0,3$; korelācija ir vidēja, ja $0,3<r_{s}<0,7$; bet cieša, ja $r_{s} \geq 0,7$.

Atbilstoši vispārpieņemtiem principiem, pētījumā par statistiski ticamām pieņemtas tās vērtības, kas mazākas par 0,05, t.i., $p<0,05$.Datu statistiskā apstrāde tika veikta ar SPSS programmu (IBM SPSS Statistics Version 23, SPSS inc., USA). 


\section{REZULTĀTI}

\subsection{Primārs un sekundārs nelabvēlīgs iznākums}

Primāru un sekundāru nelabvēlīgu iznākumu novēroja 14 pacientiem. Iemesli primāram nelabvēlīgam iznākumam MEA+MT grupā bija perioperatīvs CI $(\mathrm{n}=2)$, perioperatīvs MI $(\mathrm{n}=1)$, perioperatīva ICH ar sekojošu exitus letalis $(\mathrm{n}=1)$; PTA+MT grupā: periproceduāla infekcija, sepse ar sekojošu exitus letalis $(n=1)$, savukārt MT grupā 30 dienu laikā kopš pacienta iekḷaušanas pētījumā netika novērots neviens no primāriem nelabvēlīgiem iznākumiem. Savukārt sekundārs nelabvēlīgs iznākums gada laikā MEA+MT grupā bija novērots 5 pacientiem: exitus letalis $(\mathrm{n}=3)$, pretējās puses CI $(\mathrm{n}=2)$; PTA+MT grupā - 2 pacientiem exitus letalis: traumatiskas ICH un akūta koronāra notikuma dēḷ. Savukārt MT grupā vienam pacientam attīstìjās ipsilaterāls CI gada laikā no iekḷaušanas brīža pētījumā, un vēl vienam pacientam - akūts koronārs notikums. Visu šo pacientu dati tika iekḷauti rezultātu analīzē līdz brīdim, kad pacients vairs nespēja piedalīties pētījumā. Turklāt bija pacienti, kuri dažādu sociālu iemeslu dēḷ nevarēja ierasties uz kādu no vizìtēm. Tāpēc MEA+MT grupā pētījumu uzsāka 159 pacienti, pēc 6 mēnešiem dalību pētījumā turpināja 132 pacienti, bet pēc 12 mēnešiem - 128 pacienti. PTA+MT grupā pētījumu uzsāka 29 pacienti, pēc 6 mēnešiem dalību turpināja 27 pacienti, bet pēc 12 mēnešiem - 25 pacienti. MT grupā pētījumu uzsāka 25 pacienti, pēc 6 mēnešiem dalību turpināja 24 pacienti, bet pēc 12 mēnešiem - 22 pacienti.

Analizējot restenožu biežumu revaskularizācijas grupās, MEA+MT grupā 2 (1,5\%) no 132 pacientiem novēroja restenozi pēc 6 un 12 mēnešiem, bet PTA+MT grupā -2 (7,4\%) no 27 pacientiem ( $p=0,136$; Cramer's $V=0,15)$. Savukārt analizējot nozīmīgas miega artērijas stenozes progresēšanu MT grupā gada laikā, nevienam no pacientiem oklūzija netika novērota.

\subsection{Pacientu demogrāfiskais un klīniskais raksturojums pirms terapijas uzsākšanas}

Pētījumā iekḷauto pacientu vecums visās grupās bija līdzīgs $\left(p=0,171 ; \eta^{2}=0,01\right)$. MEA+MT grupā pacientu vecuma mediāna bija 71 (IQR: 63; 75) gadi, PTA+MT grupā - 71 (IQR: 63,4; 78), savukārt MT grupā 74 (IQR: 67; 78) gadi. Vecuma sadalījums pa grupām atspoguḷots 3.1. attēlā. 


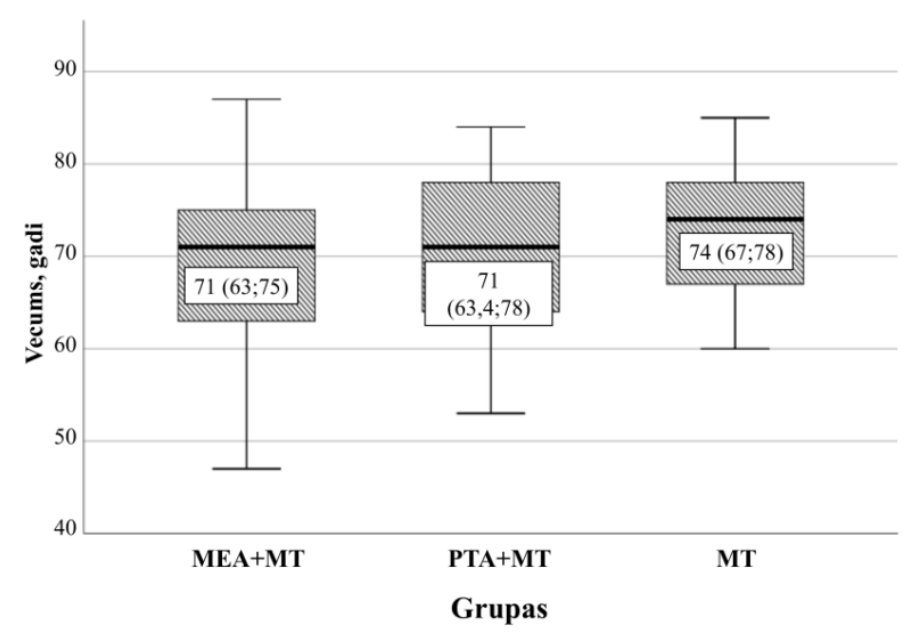

3.1. attēls. Vecuma sadalījums pa pētāmām grupām

N̦emot vērā nozīmīgas miega artērijas stenozes sastopamības atšķirības starp dzimumiem dažādos vecumos, būtiski bija noskaidrot dzimuma un vecuma sadalījumu pa grupām. Katrā no pētījuma grupām biežāk bija sastopami vīrieši, tāpēc dzimuma sadalījums starp grupām statistiski nozīmīgi neatšķīrās ( $p=0,226$; Cramer's $V=0,118)$ (3.2. attēls).

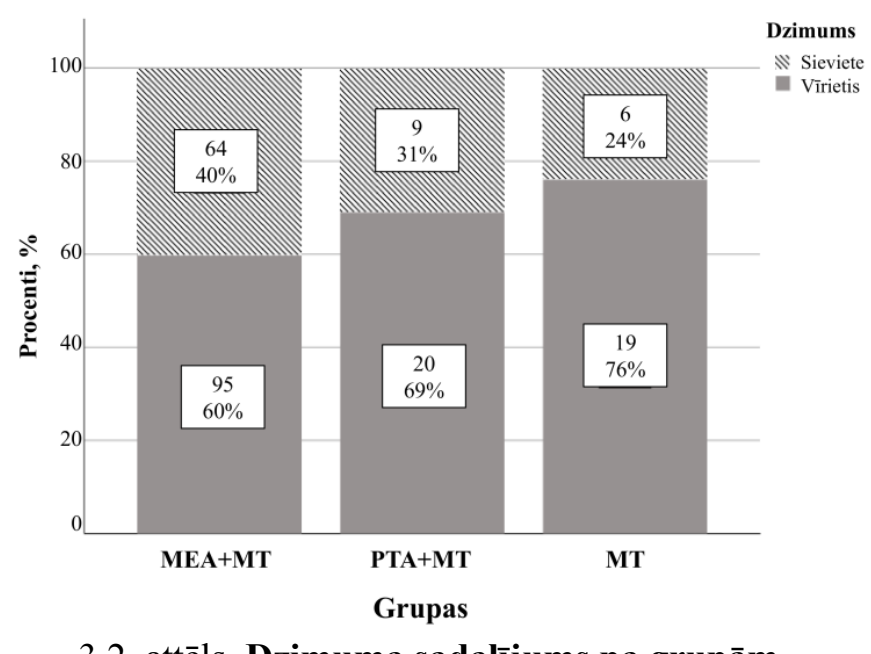

3.2. attēls. Dzimuma sadalījums pa grupām

Salīdzinot katra dzimuma vecuma mediānas vērtības starp grupām, novēroja statistiski nozīmīgu atšķirību starp vīriešu vecumiem $(p=0,041)$. MEA+MT grupā vecuma mediāna bija 67 (IQR: 60; 74) gadi, PTA+MT grupā - 70,5 (IQR: 62,25; 78,75), savukārt MT grupā - 74 (IQR: 64; 78). Tomēr veicot statistiskā efekta lieluma aprēķinus, šī statistiski nozīmīgā atšķirība netika apstiprināta $\left(\eta^{2}=0,01\right)$. Atšķirības sieviešu vecuma mediānas vērtībās starp grupām nenovēroja $\left(p=0,677 ; \eta^{2}=0,04\right)$.

Savukārt salīdzinot savstarpēji sieviešu un vīriešu vecuma mediānas vērtības katrā grupā, novēroja, ka MEA+MT grupā sievietes $(\mathrm{Me}=73$; IQR: 70; 77) bija vecākas nekā 
vīrieši $(\mathrm{Me}=67 ; \mathrm{IQR}: 60 ; 74),\left(p<0,001, \eta^{2}=0,1\right)$. Pārējās grupās, tas ir, PTA+MT (sievietes $\mathrm{Me}=72$ (IQR: 66; 75); vīrieši Me = 70,5 (IQR: 62,3; 78,75)) un MT (sievietes Me = 74 (IQR: 69,25; 77,25); vīrieši Me =74 (IQR: 64; 78)) grupās statistiski nozīmīgas atšķirības starp abu dzimumu vecumiem netika novērotas $(p>0,05)$. Vecuma sadalījums pa dzimumiem katrā pētāmā grupā attēlots 3.3. attēlā.

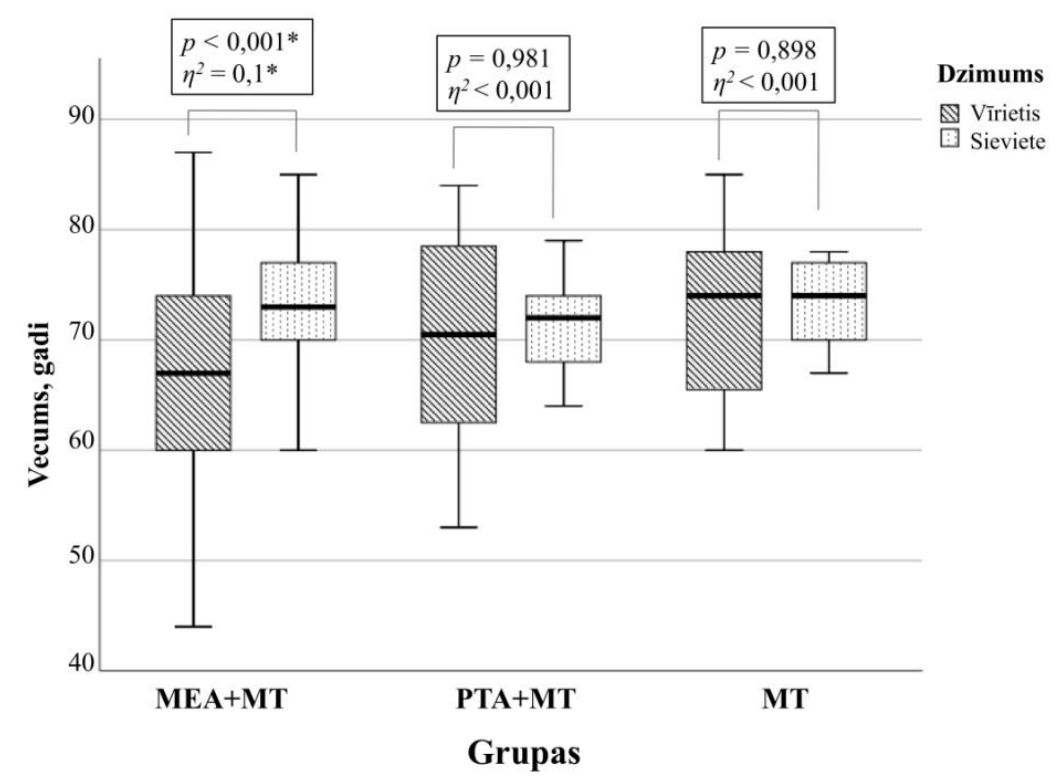

3.3. attēls. Vecuma sadalījums pa dzimumiem katrā pētāmā grupā

Pētījumā lielākai dạ̧ai pacientu bija asimptomātiska miega artērijas stenoze. Simptomātiski pacienti vairāk tika novēroti MT grupā, tomēr statistiski ticama atšķirība starp grupām netika novērota $(p=0,072$, Cramer's $V=0,165)$. Post-hoc analīzē simptomātiska miega artērija biežāk bija sastopama MT nekā MEA+MT $(p=0,01)$ grupā, tomēr statistiskā efekta lielums bija mazs (Cramer's $V=0,248)$. Analizējot pētījumā iekḷauto pacientu miega artērijas stenozes lokalizāciju, statistiski nozīmīgas atšķirības starp grupām netika novērotas ( $p=0,845 ;$ Cramer's $V=0,057$ ). Pacientu neirologiskāā stāvokḷa raksturojums atspogulots 3.1. tabulā.

3.1. tabula

Pacientu neiroloğiskā stāvokḷa raksturojums

\begin{tabular}{|c|c|c|c|c|c|}
\hline & $\begin{array}{c}\text { MEA+MT } \\
\text { n=159 }\end{array}$ & $\begin{array}{c}\text { PTA+MT } \\
\text { n }=29\end{array}$ & $\begin{array}{c}\text { MT } \\
n=25\end{array}$ & $p$ vērtība & Efekta lielums \\
\hline \multicolumn{6}{|c|}{ Cerebrovaskulārie notikumi } \\
\hline Asimptomātiski & $118(74,2 \%)$ & $20(69 \%)$ & $13(52 \%)$ & & \\
\hline \multicolumn{6}{|l|}{ Simptomātiski } \\
\hline $\mathrm{CI},(\mathrm{NIHSS} \leq 3)$ & $22(13,8 \%)$ & $6(20,7 \%)$ & $10(40 \%)$ & \multirow[t]{3}{*}{0,072} & \multirow[t]{3}{*}{ Cramer's $V=0,165$} \\
\hline TIL & $16(10,1 \%)$ & $2(6,9 \%)$ & $1(4 \%)$ & & \\
\hline amaurosis fugax & $3(1,9 \%)$ & $1(3,4 \%)$ & $1(4 \%)$ & & \\
\hline
\end{tabular}


3.1. tabulas turpinājums

\begin{tabular}{|c|c|c|c|c|c|}
\hline & $\begin{array}{c}\text { MEA+MT } \\
n=159\end{array}$ & $\begin{array}{c}\text { PTA+MT } \\
\mathrm{n}=29\end{array}$ & $\begin{array}{c}\text { MT } \\
\mathrm{n}=25\end{array}$ & $p$ vērtība & Efekta lielums \\
\hline \multicolumn{6}{|l|}{ Stenoze } \\
\hline ACI dx & $66(41,5 \%)$ & $12(41,4 \%)$ & $8(32,0 \%)$ & \multirow{3}{*}{0,845} & \multirow{3}{*}{ Cramer's $V=0,057$} \\
\hline ACI $\sin$ & $52(32,7 \%)$ & $8(27,6 \%)$ & $10(40,0 \%)$ & & \\
\hline $\begin{array}{r}\text { Bilaterāla } \\
\text { nozīmīga stenoze }\end{array}$ & $41(25,8 \%)$ & $9(31,0 \%)$ & $7(28 \%)$ & & \\
\hline
\end{tabular}

MEA+MT - pacienti, kuriem tika veikta miega artērijas endarterektomija; PTA+MT - pacienti, kuriem tika veikta miega artērijas perkutāna translumināla angioplastija un stentēšana; MT - pacienti ar nozīmīgu miega artērijas stenozi, kuri saņēma medikamentozu terapiju; CI - cerebrāls infarkts; NIHSS - Nacionālā veselības institūta insulta skala (National Instituteof Health StrokeScale); TIL - transitīva išēmiska lēkme; $\mathrm{ACI} \mathrm{dx}$-arteria carotis interna dextra; ACI sin-arteria carotis interna sinistra

Statistiski nozīmīgas atšķirības kardiovaskulāro blakussaslimšanu sastopamības biežumā starp grupām nenovēroja, izņemot MA un CD sastopamībā. MA biežāk tika novērota MT grupā. Veicot post-hoc analīzi, konstatēja, ka MA biežāk bija MT nekā MEA+MT ( $p<0,001$, Cramer's $V=0,27)$ grupā. Savukārt, CD biežāk tika novērots PTA+MT grupā. Veicot post-hoc analīzi, aprēķināja, ka CD sastopamība PTA+MT statistiski nozīmīgi atšks̄īās no MEA+MT ( $p<0,001 ;$ Cramer's $V=0,297)$ un MT ( $p=0,023 ;$ Cramer's $V=0,309)$ grupām. Arī KSS un HSM biežāk novēroja PTA+MT ( $p=0,048$ un $p=0,034)$ grupā, taču šo atšķirīibu statistiskie efekta lielumi bija mazi (Cramer's $V=0,169$ un Cramer's $V=0,197$ ). Pacientu vaskulāro riska faktoru raksturojums atspoguļots 3.2. tabulā.

3.2. tabula

Pacientu vaskulāro riska faktoru raksturojums

\begin{tabular}{|c|c|c|c|c|c|}
\hline & $\begin{array}{c}\text { MEA+MT } \\
\mathbf{n}=159\end{array}$ & $\begin{array}{c}\text { PTA+MT } \\
\mathbf{n}=29\end{array}$ & $\begin{array}{c}\text { MT } \\
\mathrm{n}=25\end{array}$ & $p$ vērtība & Efekta lielums \\
\hline KSS & $68(42,8 \%)$ & $19(65,5 \%)$ & $9(36,0 \%)$ & $0,048^{*}$ & Cramer's $V=0,169$ \\
\hline \multicolumn{6}{|l|}{ HSM } \\
\hline II & $30(18,9 \%)$ & & $10(40 \%)$ & \multirow[t]{3}{*}{$0,034 *$} & \multirow{3}{*}{ Cramer's $V=0,197$} \\
\hline III & $10(6,3 \%)$ & $4(13,8 \%)$ & $2(8 \%)$ & & \\
\hline IV & 0 & $1(3,4 \%)$ & 0 & & \\
\hline \multicolumn{6}{|l|}{$\mathrm{AH}$} \\
\hline $\begin{array}{l}\text { 2. pakāpe } \\
\text { 3. pakāpe }\end{array}$ & $\begin{array}{l}102(64,2 \%) \\
25(15,7 \%)\end{array}$ & $\begin{array}{c}17(58,6 \%) \\
5(17,2 \%)\end{array}$ & $\begin{array}{c}16(64 \%) \\
5(20 \%)\end{array}$ & 0,709 & Cramer's $V=0,094$ \\
\hline Kontrolēta AH & $70(44 \%)$ & $13(44,8 \%)$ & $13(52 \%)$ & 0,757 & Cramer's $V=0,051$ \\
\hline MA & $15(9,4 \%)$ & $6(20,7 \%)$ & $9(36 \%)$ & $0,001 *$ & Cramer's $V=0,255^{* *}$ \\
\hline PAS & $49(30,8 \%)$ & $11(39,3 \%)$ & $5(20 \%)$ & 0,314 & Cramer's $V=0,105$ \\
\hline $\mathrm{CD}$ & $21(13,2 \%)$ & $13(44,8 \%)$ & $4(16 \%)$ & $<0,001 *$ & Cramer's $V=0,281 * *$ \\
\hline Kontrolēts CD & $14(70 \%)$ & $7(63,6 \%)$ & $1(25 \%)$ & 0,235 & Cramer's $V=0,288$ \\
\hline \multicolumn{6}{|l|}{ Smēķēšana } \\
\hline nesmēķētājs & $54(34 \%)$ & $9(44 \%)$ & $11(44 \%)$ & & \\
\hline smēksētājs & $72(45,3 \%)$ & $12(41,4 \%)$ & $10(40 \%)$ & 0,764 & Cramer's $V=0,066$ \\
\hline iepriekš smēksēja & $33(20,7 \%)$ & $8(27,6 \%)$ & $4(16 \%)$ & & \\
\hline
\end{tabular}


3.2. tabulas turpinājums

\begin{tabular}{rccccc}
\hline & $\begin{array}{c}\text { MEA+MT } \\
\mathbf{n = 1 5 9}\end{array}$ & $\begin{array}{c}\text { PTA+MT } \\
\mathbf{n = 2 9}\end{array}$ & $\begin{array}{c}\mathbf{M T} \\
\mathbf{n = 2 5}\end{array}$ & $\boldsymbol{p}$ vērtība & Efekta lielums \\
\hline ĶMI (vidējāa, SD) & $27,12(4,26)$ & $27,67(4,27)$ & $27,3(3,59)$ & 0,805 & $\eta^{2}=0,002$ \\
$<18,4$ & $1(0,6 \%)$ & 0 & 0 & & \\
$18,5-24,9$ & $48(30,2 \%)$ & $8(27,6 \%)$ & $4(16 \%)$ & 0,835 & Cramer's $V=0,081$ \\
$25,0-29,9$ & $74(46,5 \%)$ & $13(44,8 \%)$ & $14(56 \%)$ & & \\
$\geq 30$ & $36(22,6 \%)$ & $8(27,6 \%)$ & $7(28 \%)$ & & \\
\hline
\end{tabular}

MEA+MT - pacienti, kuriem tika veikta miega artērijas endarterektomija; PTA+MT - pacienti, kuriem tika veikta miega artērijas perkutāna translumināla angioplastija un stentēšana; MT - pacienti ar nozīmīgu miega artērijas stenozi, kuri san̄ēma medikamentozu terapiju; KSS - koronāra sirds slimība; HSM - hroniska sirds mazspēja; AH - arteriāla hipertensija; MA - mirdzaritmija; PAS - perifēro artēriju slimība; CD - cukura diabēts; ĶMI - ķermeņa masas indekss; SD - standartnovirze; * $p<0,05 ; * *$ Cramer's $V$ efekta lielums $=0,3$ (vidējs)

Pacienti, kuri tika iekļauti medikamentozajā grupā, pirms iekļaušanas pētījumā lietoja antiagregantus retāk nekā pacienti MEA+MT un PTA+MT grupās $(p<0,001$; Cramer's $\mathrm{V}=0,252)$. Arī statīni retāk tika lietoti MT grupā $(p=0,021)$, tomēr šo atšşirību statistiskā efekta lielums bija mazs (Cramer's $V=0,190)$. Pacientu lietoto medikamentu sadalījums pa pētāmām grupām atspoguḷots 3.3 tabulā.

3.3. tabula

Lietotie medikamenti pirms iekḷaušanas pētījumā

\begin{tabular}{|c|c|c|c|c|c|}
\hline & $\begin{array}{c}\text { MEA+MT } \\
n=159\end{array}$ & $\begin{array}{c}\text { PTA+MT } \\
n=29\end{array}$ & $\begin{array}{c}\text { MT } \\
n=25\end{array}$ & $p$ vērtība & Efekta lielums \\
\hline $\begin{array}{l}\text { Nelieto } \\
\text { antiagregantus }\end{array}$ & $51(32,1 \%)$ & $7(24,1 \%)$ & $14(56 \%)$ & \multirow{4}{*}{$<0,001 *$} & \multirow{4}{*}{$\begin{array}{c}\text { Cramer's } V \\
0,252 * *\end{array}$} \\
\hline Aspirīns & $94(59,1 \%)$ & $11(37,9 \%)$ & $8(32 \%)$ & & \\
\hline Klopidogrels & $5(3,1 \%)$ & $3(10,3 \%)$ & $2(8 \%)$ & & \\
\hline $\begin{array}{l}\text { Duāla } \\
\text { antiagregantu } \\
\text { terapija }\end{array}$ & $9(5,7 \%)$ & $8(27,6 \%)$ & $1(4 \%)$ & & \\
\hline Statīni & $89(56 \%)$ & $20(69 \%)$ & $8(32 \%)$ & $0,021 *$ & Cramer's $V=0,190$ \\
\hline
\end{tabular}

MEA+MT - pacienti, kuriem tika veikta miega artērijas endarterektomija; PTA+MT - pacienti, kuriem tika veikta miega artērijas perkutāna translumināla angioplastija un stentēšana; MT - pacienti ar nozīmīgu miega

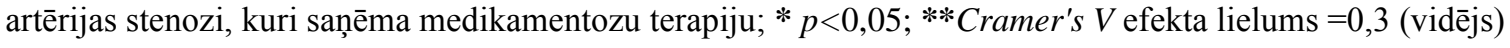

Salīdzinot blakussaslimšanas, kas varētu papildus norādīt par pētījumā iekḷauto pacientu vispārējo veselības stāvokli, statistiski nozīmīgas atšķirības starp pētījuma grupāmnetika novērotas. Izvērtējot blakussaslimšanu skaitu, tai skaitā kardiovaskulārās, vairāk blakussaslimšanas novēroja PTA+MT grupā (Me = 3(IQR: 2; 4,75)), kas statistiski ticamiatšksirās no MEA+MT $(p=0,004)$ un MT $(p=0,036)$ grupām,tomēr statistiskā efekta lielums bija mazs $\left(\eta^{2}=0,051\right)$. Citas biežākās blakussaslimšanas, uzsākot pētījumu, apkopotas 3.4. tabulā. 
Blakussaslimšanas

\begin{tabular}{|c|c|c|c|c|c|}
\hline & $\begin{array}{c}\text { MEA+MT } \\
n=159 \\
\end{array}$ & $\begin{array}{c}\text { PTA+MT } \\
\mathrm{n}=29\end{array}$ & $\begin{array}{c}\text { MT } \\
n=25\end{array}$ & $p$ vērtība & Efekta lielums \\
\hline \multicolumn{6}{|l|}{ HNS } \\
\hline 2.pakāpe & $76(48,7 \%)$ & $15(51,7 \%)$ & $11(44 \%)$ & & \\
\hline 3.pakāpe & $23(14,7 \%)$ & $5(17,2 \%)$ & $2(8 \%)$ & 0,409 & Cramer's $V=0,140$ \\
\hline 4.pakāpe & $1(0,6 \%)$ & $1(3,4 \%)$ & 0 & & \\
\hline $\begin{array}{l}\text { Hroniska plaušu } \\
\text { slimība }\end{array}$ & $9(5,7 \%)$ & $2(6,9 \%)$ & 0 & 0,445 & Cramer's $V=0,087$ \\
\hline Hroniskas sāpes & $37(23,4 \%)$ & $6(20,7 \%)$ & 0 & $0,026^{*}$ & Cramer's $V=0,186$ \\
\hline $\begin{array}{l}\text { Kataraktas vai } \\
\text { glaukomas radīti } \\
\text { redzes } \\
\text { traucējumi }\end{array}$ & $16(10,1 \%)$ & 0 & $3(12,0 \%)$ & 0,184 & Cramer's $V=0,126$ \\
\hline $\begin{array}{l}\text { Vairogdziedzera } \\
\text { hipo-/ } \\
\text { hiperfunkcija }\end{array}$ & $10(6,3 \%)$ & $4(13,8 \%)$ & $2(8 \%)$ & 0,368 & Cramer's V = 0,097 \\
\hline $\begin{array}{l}\text { Anamnēzēe } \\
\text { audzējs }\end{array}$ & $8(5 \%)$ & $2(6,9 \%)$ & $4(16 \%)$ & 0,120 & Cramer's $V=0,141$ \\
\hline $\begin{array}{l}\text { Blakus slimību } \\
\text { skaits, tai sk., } \\
\text { kardiovaskulārās } \\
\text { (IQR) }\end{array}$ & $2(1 ; 3)$ & $3(2 ; 4,75)$ & $2(1 ; 3,5)$ & $0,005^{*}$ & $\eta^{2}=0,051$ \\
\hline
\end{tabular}

\subsection{Pacientu demogrāfiskais un klīniskais raksturojums, kuri neieradās uz kādu no vizītēm}

Lai novērtētu, vai tie pacienti, kuri neieradās uz kādu no vizītēm bija atšksirīgi, tika analizēti šo pacientu demogrāfiskie un klīniskie parametri. Šo pacientu parametrus salīdzināja ar tiem pacientiem, kuri bija ieradušies uz konkrēto vizīti. Tā kā PTA+MT grupā pētījuma laikā bija tikai 4 pacienti (13\%), bet MT grupā 3 pacienti (12\%), kuri nebija ieradušies uz kādu no vizìtēm, kā arī grupas mazā pacientu skaita dēl, šo grupu pacientu dati netika analizēti. Tāpēc analizēja tikai MEA+MT grupas pacientus.

Salīdzinot pacientus, kuri bija ieradušies uz V2 vizīti ar pacientiem, kuri nebija ieradušies, secinām, ka būtiskas atšķirības nebija. Līdzīgi kā apmeklētāju grupā, arī starp tiem, kuri nebija ieradušies, vairāk bija vīriešu. Vecums abās pacientu kopās bija līdzīgs. Statistiski nozīmīgas atšķirības simptomātiskas vai asimptomātiska miega artērijas stenozes, kā arī citu 
blakussaslimšanu biežumā nebija novērotas. Abu šo pacientu kopu salīdzinājums MEA+MT grupā atspoguļots 3.5. tabulā.

3.5. tabula

MEA+MT grupas pacientu demogrāfiskais un klīniskais raksturojums, kuri neieradās uz V2 vizīti

\begin{tabular}{|c|c|c|c|c|}
\hline & $\begin{array}{c}\text { Nebija } \\
\text { ieradušies } \\
(n=27)\end{array}$ & $\begin{array}{c}\text { Bija } \\
\text { ieradušies } \\
(\mathbf{n}=132)\end{array}$ & $p$ vērtība & Efekta lielums \\
\hline \multicolumn{5}{|l|}{ Dzimums } \\
\hline vīrietis & $17(63 \%)$ & $78(59,1 \%)$ & 0.686 & Cramer's $V-0035$ \\
\hline sieviete & $10(37 \%)$ & $54(40,9 \%)$ & 0,686 & Cramer $s V=0,035$ \\
\hline Vecums, Me (IQR) & $71,5(62 ; 78)$ & $70(63 ; 75)$ & 0,495 & $r=0,054$ \\
\hline \multicolumn{5}{|l|}{ Miega artērijas stenoze } \\
\hline asimptomātiska & $21(77,8 \%)$ & $97(73,5 \%)$ & 0733 & Cramer's $V-0027$ \\
\hline simptomātiska & $6(22,2 \%)$ & $35(26,5 \%)$ & $0, / 33$ & Cramer $s v=0,02 v$ \\
\hline KSS & $12(44,4 \%)$ & $56(42,4 \%)$ & 0,945 & Cramer's $V=0,005$ \\
\hline HSM,III-IV pakāpe & $2(7,4 \%)$ & $8(6,1 \%)$ & 0,925 & Cramer's $V=0,007$ \\
\hline AH, 2., 3. pakāpe & $21(77,8 \%)$ & $106(80,3 \%)$ & 0,627 & Cramer's $V=0,039$ \\
\hline MA & $3(11,1 \%)$ & $11(8,3 \%)$ & 0,486 & Cramer's $V=0,064$ \\
\hline PAS & $11(40,7 \%)$ & $38(28,8 \%)$ & 0,227 & Cramer's $V=0,096$ \\
\hline $\mathrm{CD}$ & $3(11,1 \%)$ & $17(12,9 \%)$ & 0,925 & Cramer's $V=0,002$ \\
\hline Smēķēšana & $17(62,9 \%)$ & $89(67,4 \%)$ & 0,438 & Cramer's $V=0,061$ \\
\hline $18,5-24,9$ & $7(25,9 \%)$ & $41(31,1 \%)$ & & \\
\hline $25,0-29,9$ & $12(44,4 \%)$ & $61(46,2 \%)$ & 0,346 & Cramer's $V=0,167$ \\
\hline$>30$ & $6(22,2 \%)$ & $30(22,7 \%)$ & & \\
\hline HNS, $\geq 3$. pakāpe & $7(25,9 \%)$ & $17(12,8 \%)$ & 0,087 & Cramer's $V=0,153$ \\
\hline 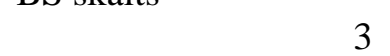 & $7(25,9 \%)$ & $26(19,7 \%)$ & & \\
\hline 4 & $2(7,4 \%)$ & $13(9,8 \%)$ & & \\
\hline 5 & $2(7,4 \%)$ & $8(6,1 \%)$ & 0,899 & Cramer's $V=0,141$ \\
\hline 6 & 0 & $1(0,8 \%)$ & & \\
\hline 7 & 0 & $1(0,8 \%)$ & & \\
\hline
\end{tabular}

Salīdzinot kognitīvās funkcijas rādītājus uzsākot pētījumu konstatēja, ka kopējās MoCA testa punktu mediānas vērtības nebija statistiski atšķirīgas ( $p=0,693, r=0,032)$. Pacientiem, kuri nebija ieradušies uz V2 vizīti, MoCA testa kopējā punktu mediānas vērtība uzsākot pētîjumu bija 25 (IQR: 21,5; 26). Savukārt pacienti, kuri bija ieradušies, $\mathrm{Me}=24,5$ (IQR: 22; 27).

Analizējot depresijas simptomu biežumu abās pacientu kopās MEA+MT grupā, statistiski nozīmīgas atšķirības nevēroja ( $p=0,25$, Cramer's $V=0,092)$. Sākotnējie depresijas simptomi bija novēroti 3 no 27 pacientiem (11,1\%), kuri nebija ieradušies uz V2, un 25 no 132 pacientiem $(18,4 \%)$, kuri bija ieradušies. 
Ar veselību saistītās dzīves kvalitātes novērtējumā nebija atšķirības starp abām pacientu kopām MEA+MT grupā, izņemot MH domēnu. Mentālās veselības domēns pacientiem, kuri nebija ieradušies uz vizīti bija augstāks $(p=0,042)$, taču statistiskā efekta lielums bija mazs. SF-36v2 vidējās vērtības atspoguḷotas 3.6. tabulā.

3.6. tabula

MEA+MT grupas pacientu, kuri neieradās uz V2 vizīti, vidējo SF-36v2 vērtību (SD) salīdzinājums

\begin{tabular}{|c|c|c|c|c|}
\hline & $\begin{array}{c}\text { Nebija } \\
\text { ieradušies } \\
(\mathbf{n}=\mathbf{2 7})\end{array}$ & $\begin{array}{c}\text { Bija } \\
\text { ieradušies } \\
(\mathbf{n = 1 3 2})\end{array}$ & $p$ vērtība & $\begin{array}{l}\text { Efekta lielums } \\
\text { Cohen's d }\end{array}$ \\
\hline $\begin{array}{l}\text { Fiziskās funkcionēšanas spējas } \\
(\mathrm{PF})\end{array}$ & $67,2(21,7)$ & $64,3(23,3)$ & 0,536 & 0,126 \\
\hline $\begin{array}{l}\text { Fiziskā veselības stāvokḷa } \\
\text { ietekme uz darbu un citām } \\
\text { ikdienas aktivitātēm (RP) }\end{array}$ & $55(25,9)$ & $53,9(26,3)$ & 0,84 & 0,042 \\
\hline Sāpes (BP) & $64,2(29,2)$ & $58,6(27,1)$ & 0,317 & 0,204 \\
\hline $\begin{array}{l}\text { Vispārējais veselības stāvoklis } \\
\text { (GH) }\end{array}$ & $47,6(13,9)$ & $46,8(16,4)$ & 0,808 & 0,05 \\
\hline Vitalitāte (VT) & $64,8(15,6)$ & $57,4(18,5)$ & 0,052 & 0,411 \\
\hline Sociālā funkcija (SF) & $70,4(22,6)$ & $69,8(26)$ & 0,9 & 0,024 \\
\hline Emocionālais stāvoklis (RE) & $65,6(26,2)$ & $64(27,6)$ & 0,779 & 0,059 \\
\hline Psihiskā veselība $(\mathrm{MH})$ & $70,7(14,4)$ & $63,5(17,7)$ & $0,042 *$ & 0,42 \\
\hline $\begin{array}{l}\text { Fiziskās vesel̄̄bas vispārējais } \\
\text { stāvoklis (PCS) }\end{array}$ & $43,9(7,9)$ & $43,3(8,5)$ & 0,742 & 0,071 \\
\hline $\begin{array}{l}\text { Psihiskās veselības vispārējais } \\
\text { stāvoklis (MCS) }\end{array}$ & $48(7,3)$ & $45,6(10,4)$ & 0,129 & 0,24 \\
\hline
\end{tabular}

MEA+MT - pacienti, kuriem tika veikta miega artērijas endarterektomija; V2 - vizīte 2 (pēc 6 mēnešiem); $\mathrm{SD}-$ standartnovirze; $* *$ Cohen's $d$ efekta lielums $=0,5$ (vidējs)

Salīdzinot tos pacientus, kuri nebija ieradušies uz V3 vizīti ar pacientiem, kuri bija ieradušies, secinām, ka arī šajā vizìtē būtiskas atškirības nebija, izņemot to, ka biežāk uz vizīti pēc gada neieradās sievietes ( $p=0,028$, Cramer's $V=0,181)$. Vecums starp abām grupām bija līdzīgs. Statistiski nozīmīgas atšķirības simptomātiskas vai asimptomātiska miega artērijas stenozes, kā arī citu blakussaslimšanu biežumā nebija novērotas, izņemot cukura diabētu. Lai gan biežāk neieradās tie, kuriem bija cukura diabēts ( $p=0,017)$, taču šo atšķirīibas statistiskā efekta lielums bija mazs (Cramer's $V=0,213$ ) Abu šo pacientu kopu salīdzinājums MEA+MT grupā atspoguļots 3.7. tabulā. 
MEA+MT grupas pacientu demogrāfiskais un klīniskais raksturojums, kuri neieradās uz V3 vizīti

\begin{tabular}{|c|c|c|c|c|}
\hline & $\begin{array}{c}\text { Nebija ieradušies } \\
(\mathrm{n}=31)\end{array}$ & $\begin{array}{c}\text { Bija ieradušies } \\
(n=128)\end{array}$ & $p$ vērtība & Efekta lielums \\
\hline \multicolumn{5}{|l|}{ Dzimums } \\
\hline vīrietis & $13(41,9 \%)$ & $82(64,1 \%)$ & \multirow[b]{2}{*}{$0,028^{*}$} & \multirow[b]{2}{*}{ Cramer's $V=0,181$} \\
\hline sieviete & $18(58,1 \%)$ & $46(35,9 \%)$ & & \\
\hline Vecums, Me (IQR) & $73(65,5 ; 76,5)$ & $70(62 ; 75)$ & 0,154 & $r=0,113$ \\
\hline \multicolumn{5}{|l|}{ Miega artērijas stenoze } \\
\hline asimptomātiska & $24(77,4 \%)$ & $93(72,6 \%)$ & \multirow[b]{2}{*}{0,5} & \multirow[b]{2}{*}{ Cramer's $V=0,054$} \\
\hline simptomātiska & $7(22,6 \%)$ & $35(27,4 \%)$ & & \\
\hline KSS & $17(54,8 \%)$ & $51(39,8 \%)$ & 0,124 & Cramer's $V=0,122$ \\
\hline HSM, III - IV pakāpe & $4(12,9 \%)$ & $6(4,7 \%)$ & 0,218 & Cramer's $V=0,123$ \\
\hline AH, 2., 3. pakāpe & $22(71 \%)$ & $105(82 \%)$ & 0,101 & Cramer's $V=0,13$ \\
\hline MA & $4(12,9 \%)$ & $11(8,6 \%)$ & 0,516 & Cramer's $V=0,047$ \\
\hline PAS & $13(41,9 \%)$ & $36(28,1 \%)$ & 0,105 & Cramer's $V=0,129$ \\
\hline $\mathrm{CD}$ & $8(25,8 \%)$ & $12(9,4 \%)$ & $0,017 *$ & Cramer's $V=0,213$ \\
\hline Smēķk̄ēšana & $18(58,1 \%)$ & $87(67,9 \%)$ & 0,249 & Cramer's $V=0,091$ \\
\hline \multicolumn{5}{|l|}{ ĶMI } \\
\hline $18,5-24,9$ & $11(35,5 \%)$ & $37(28,9 \%)$ & \multirow{3}{*}{0,508} & \multirow{3}{*}{ Cramer's $V=0,115$} \\
\hline $25,0-29,9$ & $11(35,5)$ & $63(49,2 \%)$ & & \\
\hline$>30$ & $8(25,8 \%)$ & $27(21,1 \%)$ & & \\
\hline HNS, $\geq 3$. pakāpe & $8(25,8 \%)$ & $17(13,3 \%)$ & 0,103 & Cramer's $V=0,135$ \\
\hline \multicolumn{5}{|l|}{ BS skaits } \\
\hline 3 & $10(32,3 \%)$ & $24(18,8 \%)$ & \multirow{5}{*}{0,274} & \multirow{5}{*}{ Cramer's $V=0,24$} \\
\hline 4 & $3(9,7 \%)$ & $12(9,4 \%)$ & & \\
\hline 5 & $3(9,7 \%)$ & $7(5,5 \%)$ & & \\
\hline 6 & 0 & $1(0,8 \%)$ & & \\
\hline 7 & $1(3,2 \%)$ & 0 & & \\
\hline
\end{tabular}

MEA+MT - pacienti, kuriem tika veikta miega artērijas endarterektomija; V3 - vizīte 3 (pēc 12 mēnešiem); KSS - koronāra sirds slimība; HSM - hroniska sirds mazspēja; AH - arteriāla hipertensija; MA - mirdzaritmija; PAS - perifêro artēriju slimība; CD - cukura diabēts; ĶMI - ķermeņa masas indekss; HNS - hroniska nieru slimība; BS - blakusslimību skaits; ${ }^{*} p<0,05$

Salīdzinot kognitīvās funkcijas rādītājus uzsākot pētījumu, kopējās MoCA testa punktu mediānas vērtības nebija statistiski atšķirīgas ( $p=0,216, r=0,09)$. Pacientiem, kuri nebija ieradušies uz V3 vizīti, MoCA testa kopējā punktu mediānas vērtība bija 24 (IQR: 23; 26). Savukārt pacientiem, kuri bija ieradušies, Me = 25 (IQR: 22; 27).

Analizējot depresijas simptomu biežumu abās pacientu kopās MEA+MT grupā, statistiski nozīmīgas atšķirības nevēroja $(p=0,878$, Cramer's $V=0,012)$. Sākotnējie depresijas simptomi bija novēroti 7 pacientiem no 31 (22,5\%), kuri nebija ieradušies uz V3, un 26 pacientiem no 128 (20,3\%), kuri bija ieradušies.

Ar veselību saistîtās dzīves kvalitātes novērtējumā 3 no 10 SF-36v2 domēniem bija statistiski nozīmīga atšķirība MEA+MT grupā starp pacientu kopām. Fiziskās funkcionēšanas, socilās funkcijas un fiziskās veselības vispārējā stāvokḷa domēnos zemāki rādītāji bija tiem, kuri neieradās uz V3 vizīti. SF-36v2 vidējās vērtības atspoguḷotas 3.8. tabulā. 
MEA+MT grupas pacientu, kuri neieradās uz V3 vizīti, vidējo SF-36v2 vērtību (SD) salīdzinājums

\begin{tabular}{|c|c|c|c|c|}
\hline & $\begin{array}{c}\text { Nebija } \\
\text { ieradušies } \\
(\mathbf{n}=31)\end{array}$ & $\begin{array}{c}\text { Bija } \\
\text { ieradušies } \\
(\mathbf{n = 1 2 8})\end{array}$ & $p$ vērtība & $\begin{array}{l}\text { Efekta lielums } \\
\text { Cohen's } d\end{array}$ \\
\hline $\begin{array}{l}\text { Fiziskās funkcionēšanas spējas } \\
\text { (PF) }\end{array}$ & $56,7(23,1)$ & $66,9(22,5)$ & $0,022 *$ & $0,451 * *$ \\
\hline $\begin{array}{l}\text { Fiziskā veselības stāvokjla } \\
\text { ietekme uz darbu un citām } \\
\text { ikdienas aktivitātēm (RP) }\end{array}$ & $46,8(23,2)$ & $56,1(26,6)$ & 0,069 & 0.358 \\
\hline Sāpes (BP) & $52,2(27,3)$ & $61,6(27,4)$ & 0,082 & 0,343 \\
\hline $\begin{array}{l}\text { Vispārējais veselības stāvoklis } \\
\text { (GH) }\end{array}$ & $44,3(13,5)$ & $47,7(16,5)$ & 0,284 & 0,213 \\
\hline Vitalitāte (VT) & $59,7(16,8)$ & $58,5(18,6)$ & 0,753 & 0,066 \\
\hline Sociālā funkcija (SF) & $61,4(26,4)$ & $72,1(24,7)$ & $0,03^{*}$ & 0,427 \\
\hline Emocionālais stāvoklis (RE) & $60,4(25,2)$ & $65,3(27,7)$ & 0,369 & 0,18 \\
\hline Psihiskā veselība $(\mathrm{MH})$ & $63,8(17,2)$ & $65,2(17,4)$ & 0,688 & 0,081 \\
\hline $\begin{array}{l}\text { Fiziskās veselības vispārējais } \\
\text { stāvoklis (PCS) }\end{array}$ & $40,4(7,5)$ & $44,2(8,5)$ & $0,019 *$ & $0,457 * *$ \\
\hline $\begin{array}{l}\text { Psihiskās veselības vispārējais } \\
\text { stāvoklis (MCS) }\end{array}$ & $45,6(10,6)$ & $46,1(9,7)$ & 0,761 & 0,051 \\
\hline
\end{tabular}

MEA+MT - pacienti, kuriem tika veikta miega artērijas endarterektomija; V3 - vizīte 3 (pēc 12 mēnešiem); $\mathrm{SD}$ - standartnovirze; $* p<0,05 ; * *$ Cohen's $d$ efekta lielums $=0,5$ (vidējs)

Apkopojot iepriekš minēto, pacientiem, kuri nebija ieradušies uz kādu no vizītēm (V2 vai V3 vizīti), būtiskas atšksirības netika novērotas ne demogrāfiskajos rādītājos, ne kognitīvās funkcijas un depresijas simptomu novērtējumā, ja salīdzināja ar pacientiem, kuri bija ieradušies uz konkrēto vizīti. Vienīgās atšķirības bija novērojamas tikai ar veselību saistītās dzīves kvalitātes novērtējumā - pacientiem, kuri nebija ieradušies uz V2 vizīti, MH domēna vidējā vērtība bija augstāka, taču šo atšķirību statistiskā efekta lielums bija mazs. Savukārt pacientiem, kuri neieradās uz V3 vizīti, fiziskās funkcionēšanas spēju, sociālās funkcijas un fiziskās veselības vispārējā stāvokḷa domēnu vidējās vērtības bija zemākas, kas norāda par visa veida fizisko aktivitāšu ierobežojumiem, kas radušies fiziskās veselības problēmu dēḷ.

\subsection{Kognitīvās funkcijas raksturojums}

\subsubsection{Kognitīvās funkcijas raksturojums, uzsākot pētījumu}

Uzsākot pētîjumu, kognitīiā funkcija būtiski neatšķīrās visu trīs pētāmo grupu pacientiem. Kopējā MoCA testa punktu skaita mediāna MEA+MT grupā bija 
25 (IQR: 22; 27), PTA+MT grupā - 24 (IQR: 21; 26), savukārt MT grupā - 24 (IQR: 22; 26), $\left(p=0,728, \eta^{2}=0,003\right)$. KopējāMoCA testa punktu mediānas vērtībakatrā no grupām atspogulıota 3.4. attēlā.

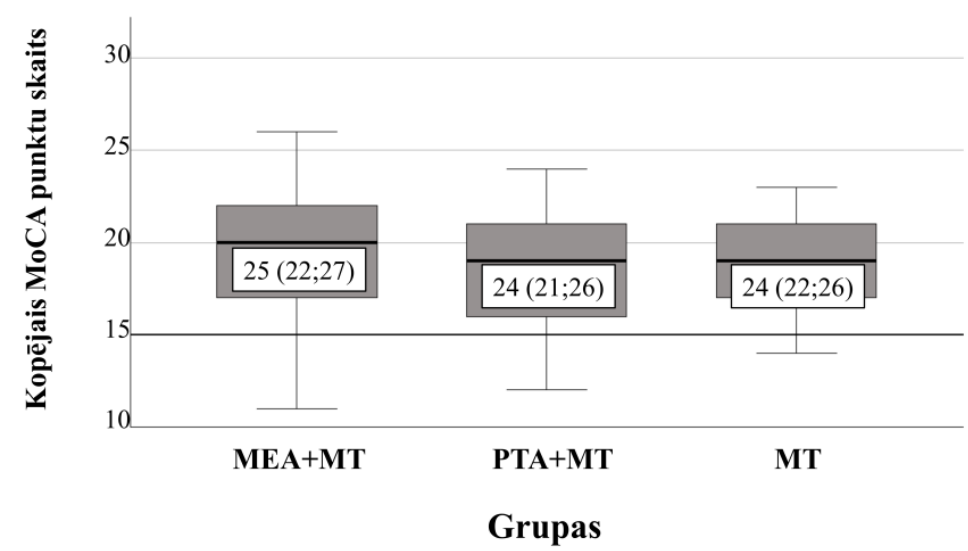

3.4. attēls. Kopējās MoCA punktu mediānas vērtības katrā no grupām, uzsākot pētījumu

Veicot MoCA skalas atsevišķu daļu analīzi, statistiski nozīmīgas atšķirības kognitīvās funkcijas domēnos starp pētāmām pacientu grupām netika atrastas (3.9. tabula)

3.9. tabula

MoCA skalas atseviškşu domēnu analīze

\begin{tabular}{lccccc}
\hline & $\begin{array}{c}\text { MEA+MT } \\
\mathbf{n = 1 5 9}\end{array}$ & $\begin{array}{c}\text { PTA+MT } \\
\mathbf{n = 2 9}\end{array}$ & $\begin{array}{c}\text { MT } \\
\mathbf{n = 2 5}\end{array}$ & $\boldsymbol{p}$ vērtība & $\begin{array}{c}\text { Efekta } \\
\text { lielums } \\
\boldsymbol{\eta}^{\mathbf{2}}\end{array}$ \\
\hline VT/VF & $4(3 ; 5)$ & $4(2 ; 5)$ & $4(2,5 ; 3,5)$ & 0,183 & 0,016 \\
\hline Nosaukšana & $3(3 ; 3)$ & $3(3 ; 3)$ & $3(3 ; 3)$ & 0,344 & 0,001 \\
\hline Uzman̄iba & $6(5 ; 6)$ & $6(5 ; 6)$ & $6(5 ; 6)$ & 0,592 & 0,005 \\
\hline Valoda & $2(1 ; 2)$ & $2(1 ; 2)$ & $2(1 ; 2)$ & 0,887 & 0,001 \\
\hline Vispārināšana & $2(1 ; 2)$ & $2(1 ; 2)$ & $2(1 ; 2)$ & 0,619 & 0,005 \\
\hline Atsaukšana atmin̄ā & $2(1 ; 4)$ & $3(1 ; 4)$ & $2(2 ; 3,5)$ & 0,943 & 0,001 \\
\hline Orientācija & $6(6 ; 6)$ & $6(6 ; 6)$ & $6(6 ; 6)$ & 0,344 & 0,001 \\
\hline MEA+MT
\end{tabular}

MEA+MT - pacienti, kuriem tika veikta miega arterijas endarterektomija; PTA+MT - pacienti, kuriem tika veikta miega artērijas perkutāna translumināla angioplastija un stentēšana; MT - pacienti ar nozīmīgu miega artērijas stenozi, kuri saṇēma medikamentozu terapiju; VT/VF - vizuāli telpiskā uztvere un vadības funkcija; Visi dati aprēķināti kā mediāna (IQR: Q1; Q3); statistiskā efekta lielums $\eta^{2}-$ partial eta squared;

Lai novērtētu kopumā, vai kāds klīniskais parametrs pacientiem ar nozīmīgu miega stenozi bija saistīts ar kognitīviem traucējumiem, tad šajā aprēķinā izmantoja kopējo pacientu skaitu, nedalot tos grupās. Šajā pētījumā novēroja, ka statistiski nozīmīgas atšksirības kognitīvās funkcijas novērtējumā (kopējais MoCA punktu skaits) netika konstatētas ne starp dzimumiem, ne arī starp pacientiem ar un bez depresijas simptomiem. Nosakot kognitīvās funkcijas atšķirības atkarībā no blakussaslimšanām, izteiktākus kognitīvus traucējumus novēroja tiem pacientiem, kuri slimoja ar $\operatorname{KSS}(p=0,006)$. Lai gan viņiem bija zemāka 
kopējā MoCA punktu vērtība, tomēr statistiskā efekta lielums bija mazs $(r=0,188)$. Kognitīvās funkcijas atšķirības starp citām blakussaslimšanām vai saistību ar to skaitu netika konstatētas $(p>0,05)$. Kognitīiās funkcijas atškirīibas netika novērotas arī atkarībā no tā, vai pacientam bija simptomātiska miega artērijas stenoze $(p>0,05)$. Nosakot kognitīvās funkcijas saistību ar vecumu, novēroja statistiski nozīmīgu vāju negatīvu korelāciju $\left(\mathrm{r}_{\mathrm{s}}=-0,267, p<0,001 ; 95 \% \mathrm{TI}-0,137 ;-0,388\right)$. Veicot viena faktora lineāro regresijas analīzi, kur atkarīgais mainīgais bija kopējais MoCA punktu skaits uzsākot pētījumu, bet neatkarīgais mainīgais bija vecums, konstatēja, ka vecums kā atsevišķa pazīme ietekmē kopējo MoCA vērtējumu pacientiem ar nozīmīgu miega artērijas stenozi tikai $6 \%$ (konstante $=30,6$, beta $=-0,094, p<0,001)$, (3.5.attēls). Apkopojot iepriekšminēto, būtiska saistība starp kognitīvo funkciju un klīniskiem parametriem, kuri varētu to ietekmēt, netika novērota. Vien̄̄gi vecumam kā pazīmei bija saistība ar kognitīvās funkcijas novērtējumu pētījuma sākumā - jo vecāks pacients, jo kognitīvā funkcija bija zemāka.

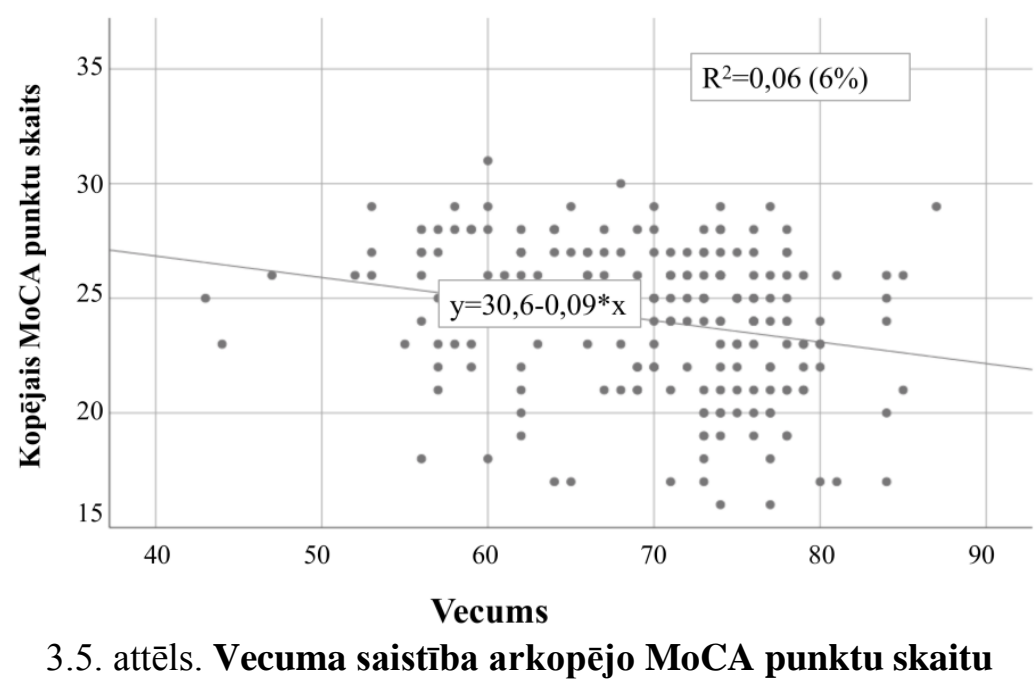

\subsubsection{Kognitīvās funkcijas izmaiṇas pēc endarterektomijas}

Analizējot kognitīvās funkcijas izmainas pacientiem, kuriem veica endarterektomiju, novēroja tās uzlabošanos pēc 6 un 12 mēnešiem ( $p<0,001$, Kendall's $W=0,28)$. Veicot posthoc analīzi, statistiski nozīmīgas atšķirības kopējā MoCA punktu skaita mediānas vērtībās bija starp pirmo un otro vizīti un starp pirmo un trešo vizīti. Lai gan atšķirības kopējā MoCA skaita mediānas vērtībās starp otro un trešo vizīti bija statistiski nozīmīgas, tomēr statistiskā efekta lielums bija mazs ( $p=0,001, r=0,2)$. Kopējā MoCApunktu skaita mediānas vērtības pirms, 6 un 12 mēnešus pēc endarterektomijas atspogulıtotas 3.6. attēlā. 


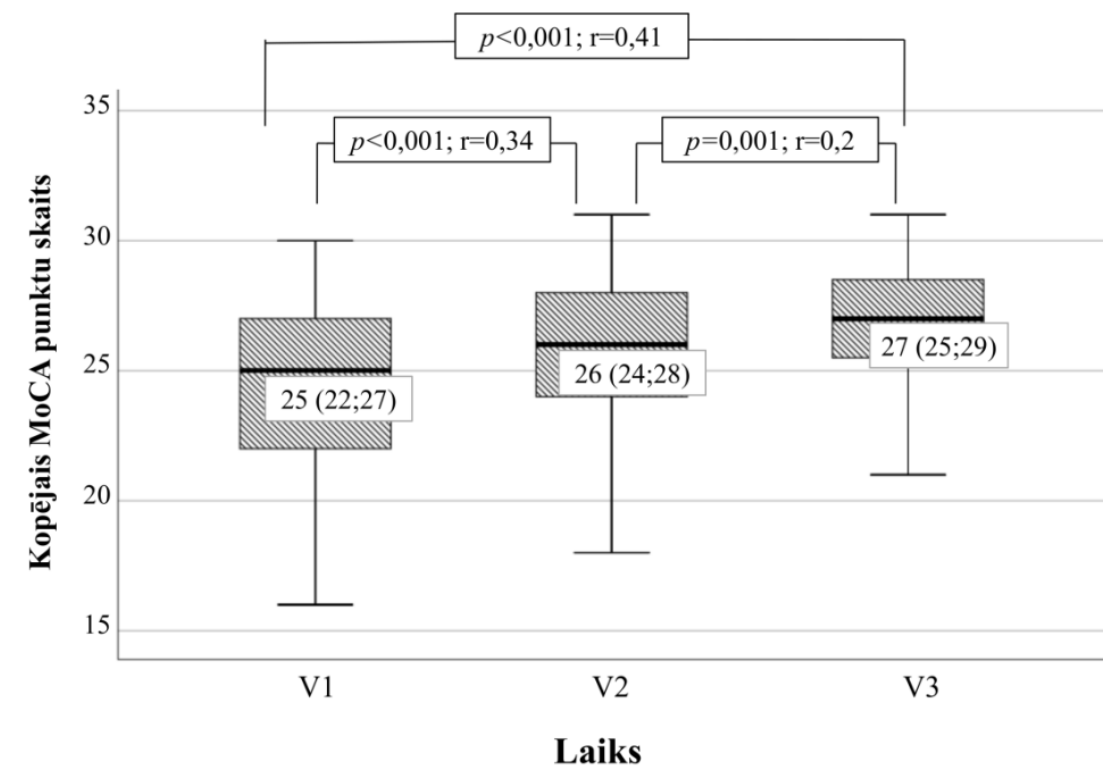

\section{6. attēls. Kopējā MoCA punktu mediānas vērtības pirms, 6 un 12 mēnešus pēc endarterektomijas}

Salīdzinot atsevišķ̧i MoCA testa domēnu mediānas vērtību izmaiņas laikā (t.i., starp vizītēm), novēroja, ka vērtības statistiski nozīmīgi palielinās tādos kognitīvos domēnos kā uzmanība ( $p=0,035$, Kendall's $W=0,033)$, valoda $(p<0,001$, Kendall's $W=0,075)$, vispārināšana $(p<0,001$, Kendall's $W=0,076)$ un atsaukšana atmiņā $(p<0,001$, Kendall's $W=0,217)$, taču šo vērtību statistiskais efekts bija mazs. Kopējā MoCA testa un tā domēnu mediānas vērtības atspoguḷotas 3.10. tabulā.

3.10. tabula

MoCA testa mediānas vērtības pacientiem, kuriem veikta miega artērijas endarterektomija

\begin{tabular}{lccccc}
\hline & V1 & V2 & V3 & $\boldsymbol{p}$ vērtība & $\begin{array}{c}\text { Efekta lielums } \\
\text { Kendall's } \boldsymbol{W}\end{array}$ \\
\hline $\begin{array}{l}\text { Kopējais MoCA } \\
\text { punktu skaits }\end{array}$ & $25(22 ; 27)$ & $26(24 ; 28)$ & $27(25 ; 29)$ & $<0,001 *$ & $0,28^{* *}$ \\
\hline VT/VF & $4(3 ; 5)$ & $4(3 ; 5)$ & $4(4 ; 5)$ & 0,254 & 0,013 \\
\hline Nosaukšana & $3(3 ; 3)$ & $3(3 ; 3)$ & $3(3 ; 3)$ & 0,135 & 0,019 \\
\hline Uzmanība & $5(6 ; 6)$ & $5(6 ; 6)$ & $5(6 ; 6)$ & $0,035 *$ & 0,033 \\
\hline Valoda & $2(1 ; 2)$ & $2(1 ; 2)$ & $2(1 ; 3)$ & $<0,001 *$ & 0,075 \\
\hline Vispārināšana & $2(1 ; 2)$ & $2(1 ; 2)$ & $2(2 ; 2)$ & $<0,001 *$ & 0,076 \\
\hline Atsaukšana atmin̄ā & $3(1 ; 4)$ & $4(2 ; 5)$ & $4(3 ; 5)$ & $<0,001 *$ & 0,217 \\
\hline Orientācija & $6(6 ; 6)$ & $6(6 ; 6)$ & $6(6 ; 6)$ & 0,103 & 0,023 \\
\hline V1
\end{tabular}

V1 - vizìte pirms endarterektomijas, V2 - vizìte 6 mēnešus pēc endarterektomijas, V3 - vizīte 12 mēnešus pēc endarterektomijas; VT/VF - vizuāli telpiskā/vadības funkcija; visi dati aprēķināti kā mediāna (IQR: Q1; Q3); ${ }^{*} p<0,05 ; * *$ Kendall's $W$ efekta lielums $\geq 0,3$ (vidējs) 
Veicot post-hoc analīzi, uzmanības $(p=0,056)$, valodas $(p=0,009)$ un vispārināšanas $(p=0,01)$ MoCA mediānas vērtībāsstatistiki nozīmīgas atšķirības novēroja starp V1 un V3 vizịtēm. Savukārt atsaukšana atmiņā statistiski nozīmīgi atšķīās katrā no vizītēm $(p=0,01)$.

\subsubsection{Kognitīvās funkcijas izmaiṇas pēc perkutānās transluminālās angioplastijas un stentēšanas}

Kopējo MoCA testa punktu mediānas vērtību palielināšanos novēroja 12 mēnešu periodā pēc endovaskulāras revaskularizācijas ( $p=0,01$, Kendall's $W=0,261)$. Veicot posthoc analīzi, statistiski nozīmīgas atšķirības kopējā MoCA punktu skaita mediānas vērtībās vēroja tikai starp pirmo un trešo vizīti $(p=0,034 ; r=0,44)$. Kopējā MoCA punktu skaita mediānas vērtības pirms, 6 un 12 mēnešus pēc angioplastijas ar stentēšanu ir atspogulotas 3.7. attēlā.

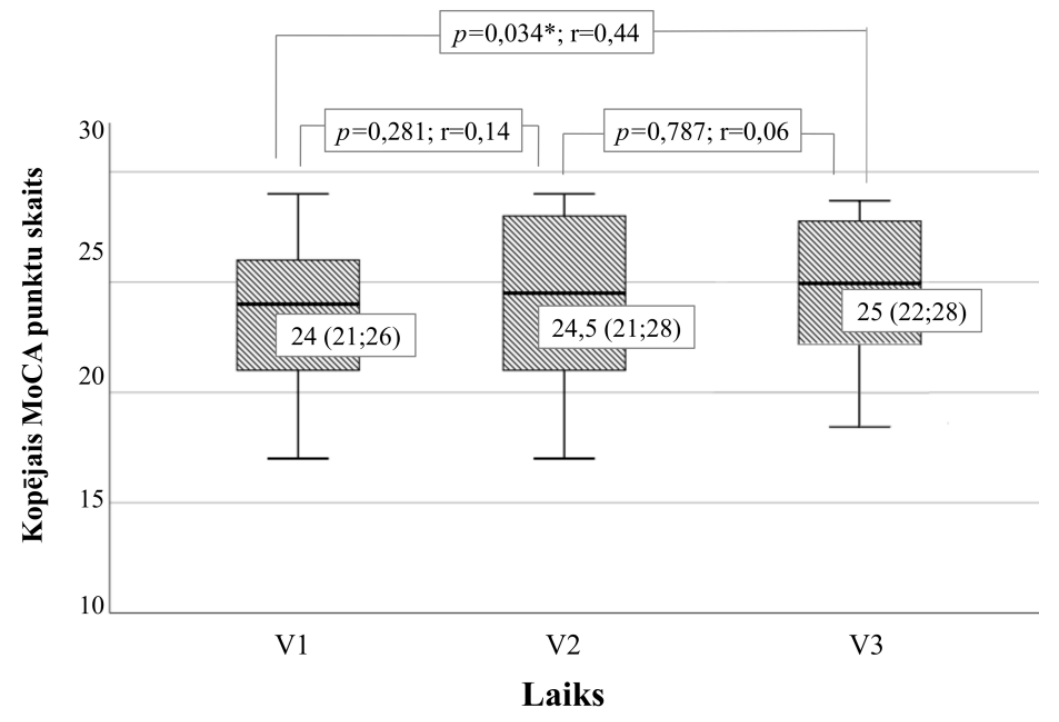

3.7. attēls. Kopējā MoCA punktu mediānas vērtības pirms, 6 un 12 mēnešus pēc angioplastijas ar stentēšanu

Vēloties noskaidrot, kurš no MoCA testa domēniem bija mainījies gada laikā pēc miega artērijas stentēšanas, statistiski nozīmīgas izmaiņas konstatēja tikai vizuāli telpiskās uztveres un vadības funkcija domēnā $(p=0,01)$, tomēr ar mazu statistiskā efekta lielumu (Kendell's $W=0,24)$. Kopējā MoCA testa un tā domēnu mediānas vērtības atspoguḷotas 3.11. tabulā. 
3.11. tabula

MoCA testa mediānas vērtības pacientiem, kuriem veikta miega artērijas angioplastija

\begin{tabular}{|c|c|c|c|c|c|}
\hline & V1 & $\mathbf{V} 2$ & $\mathbf{V 3}$ & $p$ vērtība & $\begin{array}{c}\text { Efekta lielums } \\
\text { Kendall's } W\end{array}$ \\
\hline $\begin{array}{l}\text { Kopējais MoCA } \\
\text { punktu skaits }\end{array}$ & $24(21 ; 26)$ & $24,5(21 ; 28)$ & $25(22 ; 28)$ & $0,01^{*}$ & $0,261 * *$ \\
\hline VT/VF & $3(2 ; 5)$ & $4(3 ; 5)$ & $4(3 ; 5)$ & $0,01 *$ & 0,24 \\
\hline Nosaukšana & $3(3 ; 3)$ & $3(3 ; 3)$ & $3(3 ; 3)$ & 0,368 & 0,053 \\
\hline Uzmanība & $5(4 ; 6)$ & $6(5 ; 6)$ & $5(4 ; 6)$ & 0,572 & 0,029 \\
\hline Valoda & $2(1 ; 2)$ & $1(1 ; 2)$ & $1(1 ; 2)$ & 0,917 & 0,005 \\
\hline Vispārināšana & $2(1 ; 2)$ & $1(1 ; 2)$ & $2(1 ; 2)$ & 0,289 & 0,065 \\
\hline $\begin{array}{l}\text { Atsaukšana } \\
\text { atmiṇā }\end{array}$ & $3(0,75 ; 4)$ & $4(1,75 ; 4)$ & $3(1,75 ; 4)$ & 0,144 & 0,108 \\
\hline Orientācija & $6(6 ; 6)$ & $6(6 ; 6)$ & $6(6 ; 6)$ & 0,368 & 0,053 \\
\hline
\end{tabular}

\subsubsection{Kognitīvās funkcijas izmaiṇas medikamentozās terapijas grupā}

Kopējās MoCA punktu skaita mediānas vērtības statistiski nozīmīgi neatšķ̄īrās starp vizìtēm 12 mēnešu laika periodā pacientiem, kuri saņēma medikamentozo terapiju ( $p=0,295$; Kendall's $W=0,081)$. Veicot kognitīvās funkcijas MoCA testa domēnu mediānas vērtību salīdzināšanu starp vizītēm, tika novērota statistiski nozīmīga uzlabošanās atmiṇas domēnā $(p=0,027)$, tomēr statistiskais efekts bija mazs (Kendall's $W=0,242)$. Kopējā MoCA testa un tā domēnu mediānas vērtības atspoguḷotas 3.12. tabulā.

3.12. tabula

MoCA testa mediānas vērtības pacientiem medikametozās terapijas grupā

\begin{tabular}{lccccc}
\hline V1 & V2 & V3 & $\boldsymbol{p}$ vērtība & $\begin{array}{c}\text { Efekta lielums } \\
\text { Kendall's } \boldsymbol{W}\end{array}$ \\
\hline $\begin{array}{l}\text { Kopējais MoCA } \\
\text { punktu skaits }\end{array}$ & $25(23 ; 26)$ & $26(23 ; 27)$ & $26(23 ; 28)$ & 0,295 & 0,081 \\
\hline VT/VF & $4(3 ; 4)$ & $4(3 ; 5)$ & $4(2 ; 5)$ & 0,973 & 0,002 \\
\hline Nosaukšana & $3(3 ; 3)$ & $3(3 ; 3)$ & $3(3 ; 3)$ & $>0,999$ & 0,000 \\
\hline Uzman̄̄ba & $6(6 ; 6)$ & $6(5 ; 6)$ & $6(5 ; 6)$ & 0,507 & 0,045 \\
\hline Valoda & $2(1 ; 2)$ & $1(1 ; 2)$ & $2(1 ; 3)$ & 0,531 & 0,042 \\
\hline Vispārināšana & $2(1 ; 2)$ & $2(2 ; 2)$ & $2(2 ; 2)$ & 0,229 & 0,098 \\
\hline $\begin{array}{l}\text { Atsaukšana } \\
\text { atmin̄āa }\end{array}$ & $2(2 ; 3)$ & $3(2 ; 4)$ & $4(3 ; 5)$ & $0,027 *$ & 0,242 \\
\hline Orientācija & $6(6 ; 6)$ & $6(6 ; 6)$ & $6(6 ; 6)$ & $>0,999$ & $<0,099$ \\
\hline V1
\end{tabular}

V1 - vizīte pirms iekḷaušanas pētījumā, V2 - vizīte 6 mēnešus pēc iekḷaušanas pētījumā, V3 - vizīte 12 mēnešus pēc iekḷaušanas pêtījumā; VT/VF - vizuāli telpiskā/vadības funkcija;visi dati aprēķināti kā mediāna (IQR: Q1; Q3); * $p<0,05 ; * *$ Kendall's $W$ efekta lielums $\geq 0,3$ (vidējs) 


\subsubsection{Kognitīvās funkcijas izmaiṇu atšķirības starp pielietotām ārstēšanas metodēm}

Lai varētu novērtēt kognitīiās funkcijas izmaiṇu atšķirības gada laikā starp pielietotām ārstēšanas metodēm, tika salīdzinātas MoCA testa kopējās kognitīvās funkcijas relatīvā izteiktības vērtība starp pētījuma grupām. Pēc 6 mēnešiem kopējās kognitīvās funkcijas relatīvā izteiktības mediānas vērtība MEA+MT grupā bija 0,036 (IQR: 0; 0,14), PTA+MT grupā: 0,048 (IQR: 0; 0,08) un MT grupā: 0,04 (IQR: 0; 0,101), kas nebija statistiski nozīmīgi atšķirīgas starp grupām $\left(p=0,962, \eta^{2}=0,347\right)$. Līdzịgi pēc 12 mēnešiem MoCA relatīvās starpības mediānās vērtības MEA+MT grupā bija 0,074 (IQR: 0; 0,136), PTA+MT grupā: 0,064 (IQR: 0; 0,125) un MT grupā: 0,07 (IQR:-0,068; 0,11), kas nebija statistiski nozīmīgi atšksirīgas savā starpā $\left(p=0,654, \eta^{2}=0,332\right)$.

\subsubsection{Kognitīvās funkcijas izmaiṇu un klīnisko raksturlielumu savstarpējā saistība}

Izvērtējot, vai MoCA kopējās relatīvās izteiktības vērtības ir saistītas ar vecumu, dzimumu, kardiovaskulāriem riska faktoriem, blakussaslimšanām, simptomātiskas vai asimptomātiskas miega artērijas stenozes pusi katrā pētāmā grupā, statistiski nozīmīgas atšķirības un saistības ar kādu no klīniskiem raksturlielumiem netika konstatētas $(p>0,05)$.

Savukārt nosakot pirmās vizītes kognitīvās funkcijas stāvokḷa korelāciju ar kognitīvās funkcijas izmaiņām, tas ir, MoCA kopējo relatīvās izteiktības mediānas vērtību pēc 6 un 12 mēnešiem, tika novērota statistiski nozīmīga vidēji cieša negatīva korelācija gan pēc 6 mēnešiem $\left(\mathrm{r}_{\mathrm{s}}=-0,367, p<0,001 ; 95 \% \mathrm{TI}-0,51 ;-0,21\right)$, gan pēc 12 mēnešiem $\left(\mathrm{r}_{\mathrm{s}}=-0,471, p<0,001 ; 95 \% \mathrm{TI}-0,6 ;-0,32\right)$ pacientiem, kuriem veica miega artērijas endarterektomiju.

Veicot viena faktora lineāro regresijas analīzi, kur neatkarīgais main̄̄gais bija kopējais MoCA punktu skaits uzsākot pētījumu, bet atkarīgais mainīgais bija MoCA kopējā relatīvās izteiktības mediānas vērtība, konstatēja, ka MoCA kopējais punktu skaits pirms revaskularizācijas ietekmē kopējo MoCA relatīvās izteiktības vērtību par 18,2\% pēc 6 mēnešiem (konstante $=0,47$, beta $=-0,02, p<0,001$ ) un par 21,3\% pēc 12 mēnešiem (konstante $=0,56$, beta $=-0,02, p<0,001)$. Tādējādi norādot, ka pacientiem ar sliktāku kognitīvo funkciju pētījuma sākumā paredzama ievērojamāka tās uzlabošanās. Kopējā kognitīvās funkcijas relatīvās izteiktības vērtības korelācija ar sākotnējo kopējo MoCA punktu skaitu MEA+MT pacientu grupā atspoguḷota 3.8.attēlā. 

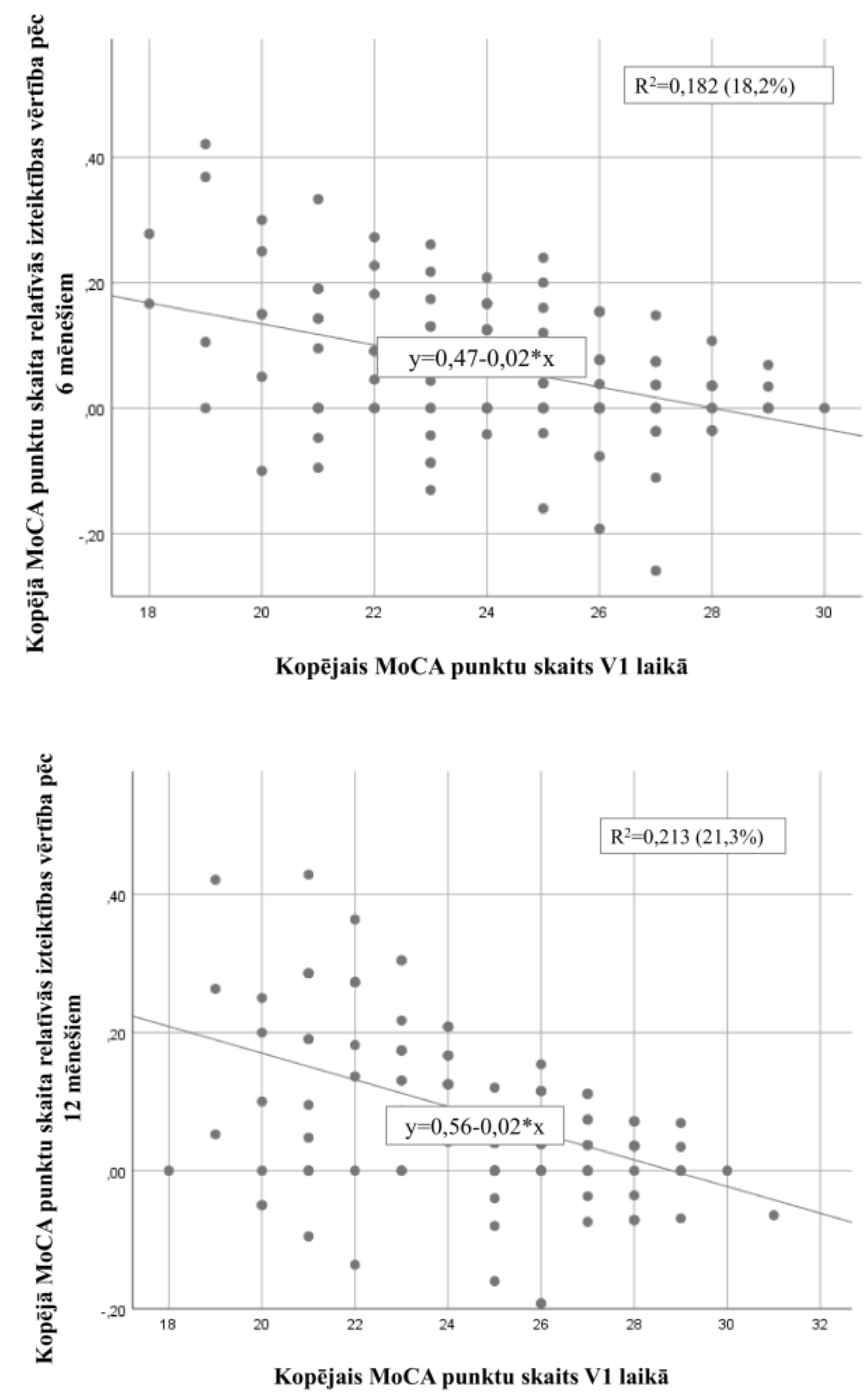

\section{8. attēls. Kopējā kognitīvās funkcijas relatīvās izteiktības vērtības korelācija ar sākotnējo kopējo MoCA punktu skaitu MEA+MT pacientu grupā}

Līdzīga korelācija tika novērota arī medikamentozās terapijas grupā pēc 6 mēnešiem $\left(\mathrm{r}_{\mathrm{s}}=-0,542, p=0,009 ; 95 \% \mathrm{TI}-0,76 ;-0,01\right)$ un pēc 12 mēnešiem $\left(\mathrm{r}_{\mathrm{s}}=-0,489, p=0,047\right.$; $95 \% \mathrm{TI}-0,78 ;-0,16)$, tomēr ticamības intervāls nebija ciešs. Veicot viena faktora lineāro regresijas analīzi, kur neatkarīgais mainīgais bija kopējais MoCA punktu skaits uzsākot pētìjumu, bet atkarīgais mainīgais bija kopējā MoCA relatīvās izteiktības vērtības, tika konstatēts, ka kopējais MoCA punktu skaits pirms revaskularizācijas ietekmē kopējo MoCA relatīiās izteiktības vērtību par 26,2\% pēc 6 mēnešiem (konstante $=0,51$, beta $=-0,02$, $p=0,015$ ) un par 21,5\% pēc 12 mēnešiem (konstante $=0,81$, beta $=-0,03, p<0,044$ )

Tomēr šāda statistiski ticama saistība starp kognitīvas funkcijas stāvokli V1 laikā un tā saistību ar kognitīvās funkcijas izmaiņām laikā PTA+MT grupā netika novērota ne pēc 6 mēnešiem $\left(r_{\mathrm{s}}=-0,324, p=0,163\right)$, ne arī pēc 12 mēnešiem $\left(r_{\mathrm{s}}=0,354, p=0,137\right)$. 
Tā kā ir zināma asociācija starp kognitīvo funkciju un depresiju, analizējām, vai ir saistība starp kognitīvās funkcijas izmaiṇām, tas ir, kopējās MoCA relatīvās izteiktības vērtībām pacientiem ar vai bez depresijas simptomiem, tomēr šajā pētījumā pārliecinoši šādu saistību pierādīt neizdevās nevienā no pētāmām grupām $(p>0,05)$.

\subsection{Depresijas simptomu raksturojums}

\subsubsection{Depresijas simptomu raksturojums, uzsākot pētījumu}

PHQ-9 skalas mediānas vērtība visās 3 grupās bija līdzịga: MEA+MT grupā mediānas vērtība bija 5 (IQR: 2; 9), PTA+MT grupā Me = 6 (IQR: 2; 10) un MT grupā $\mathrm{Me}=6(\mathrm{IQR}: 3 ; 10),\left(p=0,3, \eta^{2}=0,014\right)$.

Ja depresijas simptomu un to smaguma pakāpes noteikšanai izmantoja PHQ-9 iedalījumu atkarībā no kopējā punktu skaita, tad statistiski nozīmīgas atšksirības smaguma pakāpju biežumā visās trīs pētāmajās grupās nevēroja ( $p=0,685$, Cramer's $\mathrm{V}=0,119)$. Depresijas simptomu smaguma pakāpju sastopamība katrā pētāmā grupā atspoguḷota 3.9. attēlā.

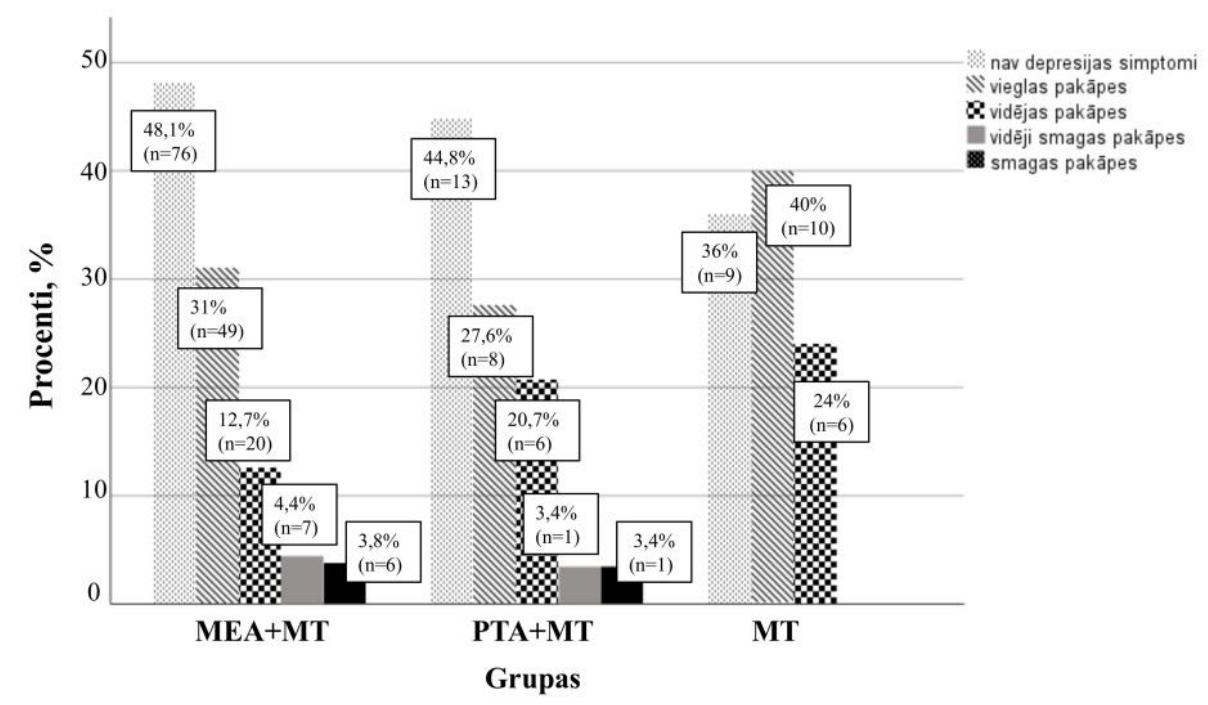

3.9. attēls. Depresijas simptomu smaguma pakāpes, uzsākot pētījumu

Līdzīgi, statistiski nozīmīgas atšķirības starp grupām netika atrastas $(p=0,987$, Cramer's $\mathrm{V}=0,029)$, ja depresijas noteikšanai izmantoja PHQ-9 kritērijus, kas norāda par rekurentiem depresīviem traucējumiem vai subklīnisku depresiju (3.10. attēls). 


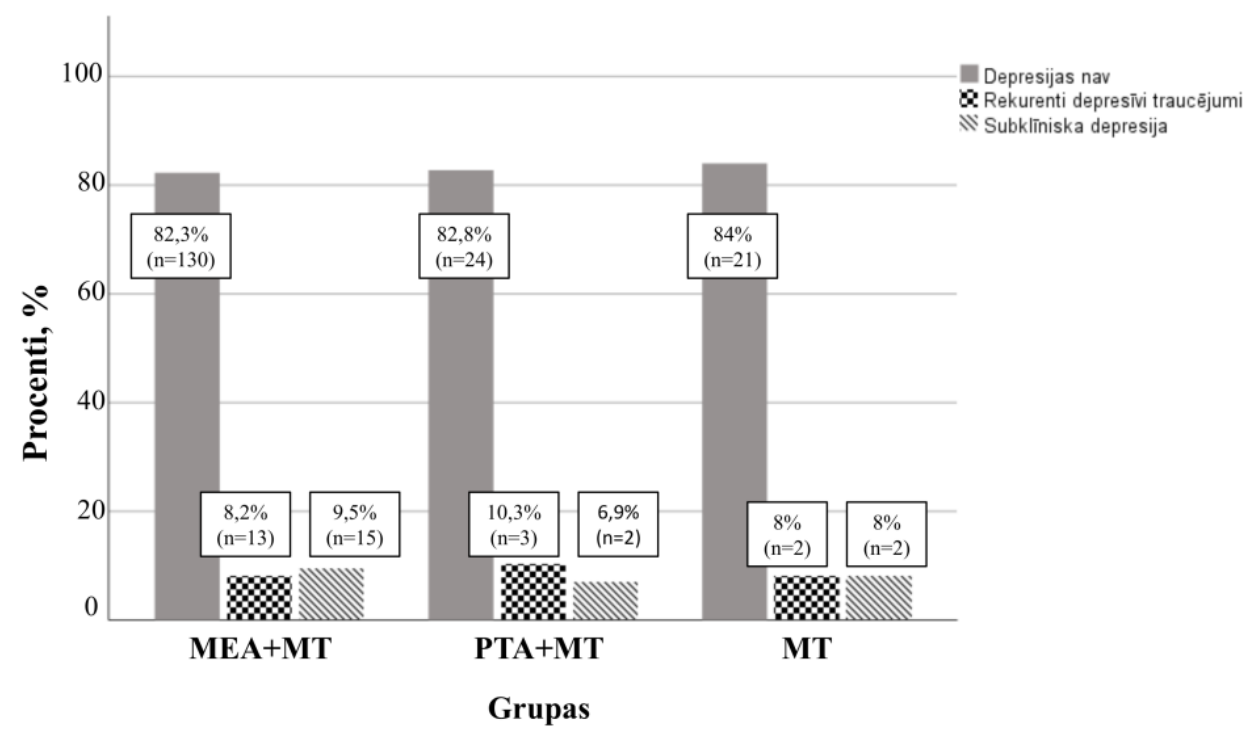

3.10. attēls. Rekurentu depresīvu traucējumu un subklīniskas depresijas biežums

Lai noteiktu iespējamos faktorus, kas biežāk varētu būt asociēti ar depresijas simptomiem visiem pacientiem ar nozīmīgu miega artērijas stenozi, nedalot tos grupās pirms revaskularizācijas, tika analizēti dažādi klīniskie raksturlielumi. Vecuma mediānas bija līdzīgas pacientiem ar $(\mathrm{Me}=71$; IQR: 62; 76) un bez $(\mathrm{Me}=71 ; \mathrm{IQR}: 63,5 ; 76)$ depresijas simptomiem, $(p=0,883, r=0,01)$. Depresijas simptomu saistību ar simptomātisku vai asimptomātisku miega artērijas stenozi nenovēroja ( $p=0,134$, Cramer's $V=0,088)$, kā arī ar to, kurā dienā pēc CI tika veikta depresijas simptomu novērtēšana ( $p=0,133, r=0,1)$. Savukārt nosakot dzimuma asociāciju ar depresijas simptomu sastopamību, PHQ-9 depresijas skrīninga testā $\geq 10$ punkti biežāk bija sastopami sievietēm $(29,5 \%, n=23)$ nekā vīriešiem $(17,9 \%, \mathrm{n}=24)$ no kopējā pacientu skaita, tomēr atšķirība nebija statistiski nozīmīga ( $p=0,06 ;$ Cramer's $V=0,134)$. Ja analizēja depresijas simptomu saistību ar blakussaslimšanām, tad novēroja statistiski nozīmīgu asociāciju starp depresijas simptomiem un koronāru sirds slimību, tas ir, pacientiem ar KSS depresijas simptomi bija biežāk sastopami $(30,2 \%, \mathrm{n}=29)$ nekā pacientiem bez $\operatorname{KSS}(15,5 \%, \mathrm{n}=18), p=0,01$, Cramer's $V=0,179$. Nosakot risku, pacientiem ar KSS bija 2,4 reizes lielāka iespēja, ka attīstīsies depresijas simptomi (95\%TI 1,212; 4,583) nekā pacientiem, kuri neslimoja ar KSS. Depresijas simptomu saistība ar HSM ( $p=0,454$, Cramer's $V=0,051)$, arteriālu hipertensiju ( $p=0,897$, Cramer's $V=0,009)$, MA $(p=0,869$, Cramer's $V=0,011), \mathrm{CD}(p=0,098$, Cramer's $V=0,114)$, PAS ( $p=0,213$, Cramer's $V=0,086)$ netika novērotas. Kā arī saistība starpizglītību (< 12 skolas gadi) un depresijas simptomiem netika novērota $(p=0,452$, Cramer's $V=0,052)$. Apkopojot iepriekš minēto, pētījuma sākumā pacientiem ar nozīmīgu miega artērijas stenozi depresijas simptomi biežāk bija sastopami sievietēm un pacientiem, 
kuri slimoja ar koronāru sirds slimību. Taču jāatzīmēe, ka statistiskā efekta lielums šiem rādītājiem bija mazs.

\subsubsection{Depresijas simptomu biežums pēc endarterektomijas}

PHQ-9 mediānas vērtības pacientiem pirms, 6 un 12 mēnešus pēc endarterektomijas nemainījās (pirms endarterektomijas Me =5 (IQR: 2;9), pēc 6 mēnešiem Me =5 (IQR: 2;8), pēc 12 mēnešiem Me =5 (IQR: 2;9), $p=0,542$, Kendall's $W=0,008)$. Analizējot to pacientu skaitu, kuriem bija depresijas simptomi, tas ir, PHQ-9 $\geq 10$ punktiem, pirms, 6 un 12 mēnešu pēc endarterektomijas, statistiski nozīmīgas atšķirības nekonstatēja $(p=0,485$; Kendall's $W=0,007)$. Līdzīgi statistiski nozīmīgas atšķirības starp vizītēm netika atrastas ( $p=0,964$, Kendall's $W=0,001)$, ja depresijas noteikšanai izmantoja PHQ-9 kritērijus, kas atbilst rekurentiem depresīviem traucējumiem vai subklīniskai depresijai. Depresijas simptomu izmaiņas gada laikā pacientiem, kuriem veica endarterektomiju, atspoguļotas 3.11 attēlā.

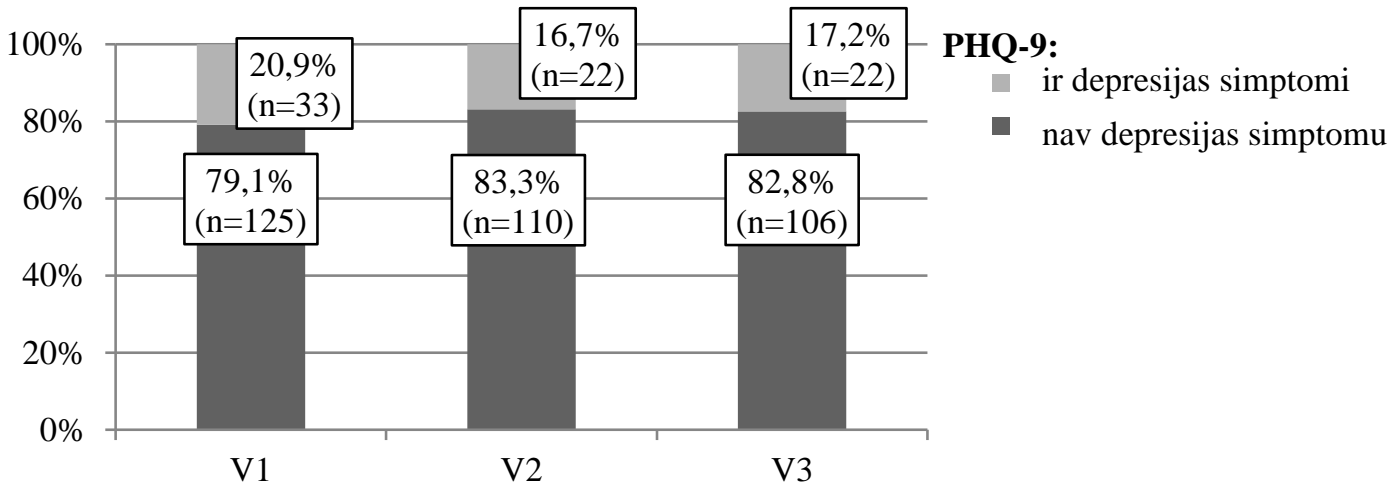

3.11.attēls. Pacientu skaits ar vai bez depresijas simptomiem pirms, 6 un 12 mēnešus pēc endarterektomijas

Analizējot depresijas simptomu izmaiņas pēc 6 mēnešiem, tad no tiem pacientiem, kuriem sākotnēji bija depresija $(n=31)$, tikai nedaudz vairāk kā pusei depresijas simptomi mazinājās $(58,1 \%, \mathrm{n}=18)$, bet 41,9\% (n=13) depresijas simptomi saglabājās. Tomēr šì atšķirība nebija statistiski nozīmīga ( $p=0,17, g=0,15)$. Jāatzīmēe, ka no tiem pacientiem, kuriem sākotnēji nebija depresija $(\mathrm{n}=101)$, pēc 6 mēnešiem tonovēroja 9 pacientiem $(8,9 \%)$. Depresijas simptomu izmaiņas pēc 6 mēnešiem pacientiem, kuriem veica MEA, atspoguļotas 3.12. attēlā.

Savukārt, ja salīdzina depresijas simptomu izmaiņas pēc gada, tad līdzīgi kā V2 laikā, pacientiem, kuriem sākotnēji bija depresija $(n=27)$, tikai nedaudz vairāk kā pusei 59,2\% ( $n=16)$ depresijas simptomi mazinājās, bet 40,8\% (n=11) depresijas simptomi saglabājās. Šì 
atšķirība nebija statistiski nozīmīga $(p=0,557 ; g=0,08)$. Depresijas simptomu izmaiņas pēc 12 mēnešiem pacientiem, kuriem veica MEA, atspoguḷotas 3.12. attēlā.
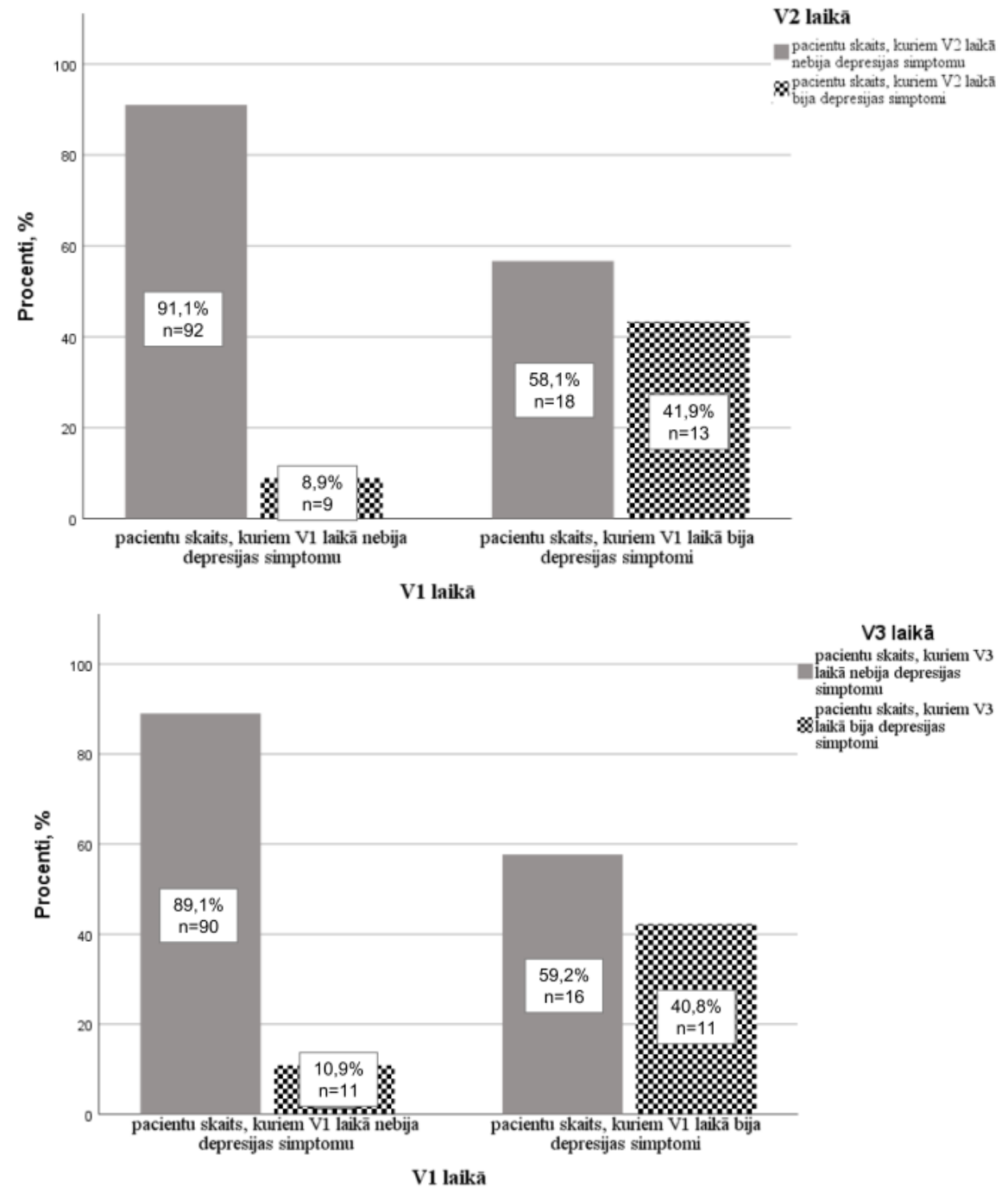

3.12. attēls. Depresijas simptomu izmaiṇas pēc 6 un 12 mēnešiem pacientiem, kuriem veica endarterektomiju.

\subsubsection{Depresijas simptomu biežums pēc perkutānās transluminālās angioplastijas un stentēšanas}

PHQ-9 anketas punktu skaita mediānas vērtība pacientiem pirms, 6 un 12 mēnešus pēc miega artērijas angioplastijas nemainījās (pirms angioplastijas Me = 6 (IQR: 2;10); pēc 6 mēnešiem Me = 7 (IQR: 2;12); pēc 12 mēnešiem Me = 7 (IQR: 5;14), p = 0,17, Kendall's $W=0,093)$. Analizējot pacientu skaitu, kuriem bija depresijas simptomi pirms, 6 un 12 mēnešus pēc PTA, līdzīgi kā miega artērijas endarterektomijas grupā, depresijas simptomu biežums statistiski ticami neatšķīrās $(p=0,165$, Kendall's $W=0,095)$. Depresijas simptomu izmaiņas gada laikā pacientiem, kuriem veica PTA, atspoguḷotas 3.13. attēlā. 


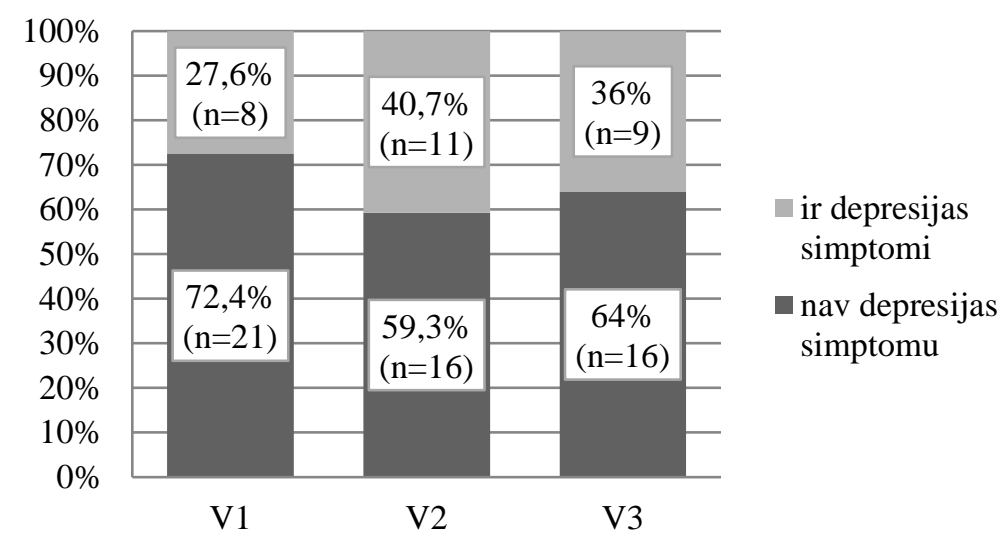

3.13. attēls. Depresijas simptomi pirms, 6 un 12 mēnešus pēc angioplastijas

Savukārt, ja analizē depresijas simptomu biežumu pēc PHQ-9 kritērijiem, kas norāda par iespējamiem rekurentiem depresīviem traucējumiem vai subklīnisku depresiju, tad gan rekurentu depresīvu traucējumu, gan subklīniskas depresijas biežums palielinājās pēc PTA. Lai gan minētās atšķkirības, kas atspoguḷotas 3.13. tabulā, bija gandrīz statistiski nozīmīgas, tomēr statistiskā efekta lielums bija mazs $(p=0,05$, Kendall's $W=0,158)$. Zemāk esošajā tabulā attēlota post-hoc analīze depresijas simptomu biežumam pirms, 6 un 12 mēnešus pēc endovaskulāras revaskularizācijas (3.13. tabula).

3.13. tabula

Rekurentu depresīvu traucējumu un subklīniskas depresijas biežums pēc angioplastijas

\begin{tabular}{|c|c|c|c|}
\hline & $\begin{array}{c}\text { V1 } \\
\text { n }(\%)\end{array}$ & $\begin{array}{c}\text { V2 } \\
\text { n }(\%)\end{array}$ & $\begin{array}{c}\mathrm{V3} \\
\mathrm{n}(\%)\end{array}$ \\
\hline Nav depresijas & $21(72,4 \%)$ & $16(59,3 \%)$ & $16(64 \%)$ \\
\hline $\begin{array}{l}\text { Rekurenti depresīvi } \\
\text { traucējumi }\end{array}$ & $3(10,3 \%)$ & $6(22,2 \%)$ & $5(20 \%)$ \\
\hline \multirow[t]{4}{*}{ Subklīniska depresija } & $2(6,9 \%)$ & $5(18,5 \%)$ & $4(16 \%)$ \\
\hline & $p=($ &, 24 & \\
\hline & & \multicolumn{2}{|c|}{$p=0,157 ; r=0,23$} \\
\hline & & $p=0,076 ; r=0,25$ & $\downarrow$ \\
\hline
\end{tabular}

Analizējot depresijas simptomu izmaiņas pēc 6 mēnešiem, no tiem pacientiem, kuriem sākotnēji bija depresijas simptomi $(n=8)$, tikai 1 pacientam depresijas simptomi vairs nebija pēc 6 mēnešiem, pārējiem 7 pacientiem - saglabājās $(p=0,375)$. Depresijas simptomu izmaiņas pacientiem pēc 6 mēnešiem, kuriem veica PTA, atspoguḷotas 3.14. attēlā. 
Savukārt, ja salīdzina depresijas simptomu izmaiņas pēc 12 mēnešiem, tad no pacientiem, kuriem sākotnēji bija depresija $(n=8), 3$ pacientiem pēc gada depresijas simptomi vairs netika novēroti. Konstatētās izmaiņas nebija statistiski nozīmīgi atšķirīgas $(p=0,97)$. Arī pacientu skaits, kuriem sākotnēji nebija depresijas simptomu, bet parādījās pēc 6 vai 12 mēnešiem, statistiski nozīmīgi neatšķīās $(p>0,05)$. Depresijas simptomu izmaiņas pēc 12 mēnešiem pacientiem, kuriem veica PTA atspoguḷotas, 3.16. attēlā.
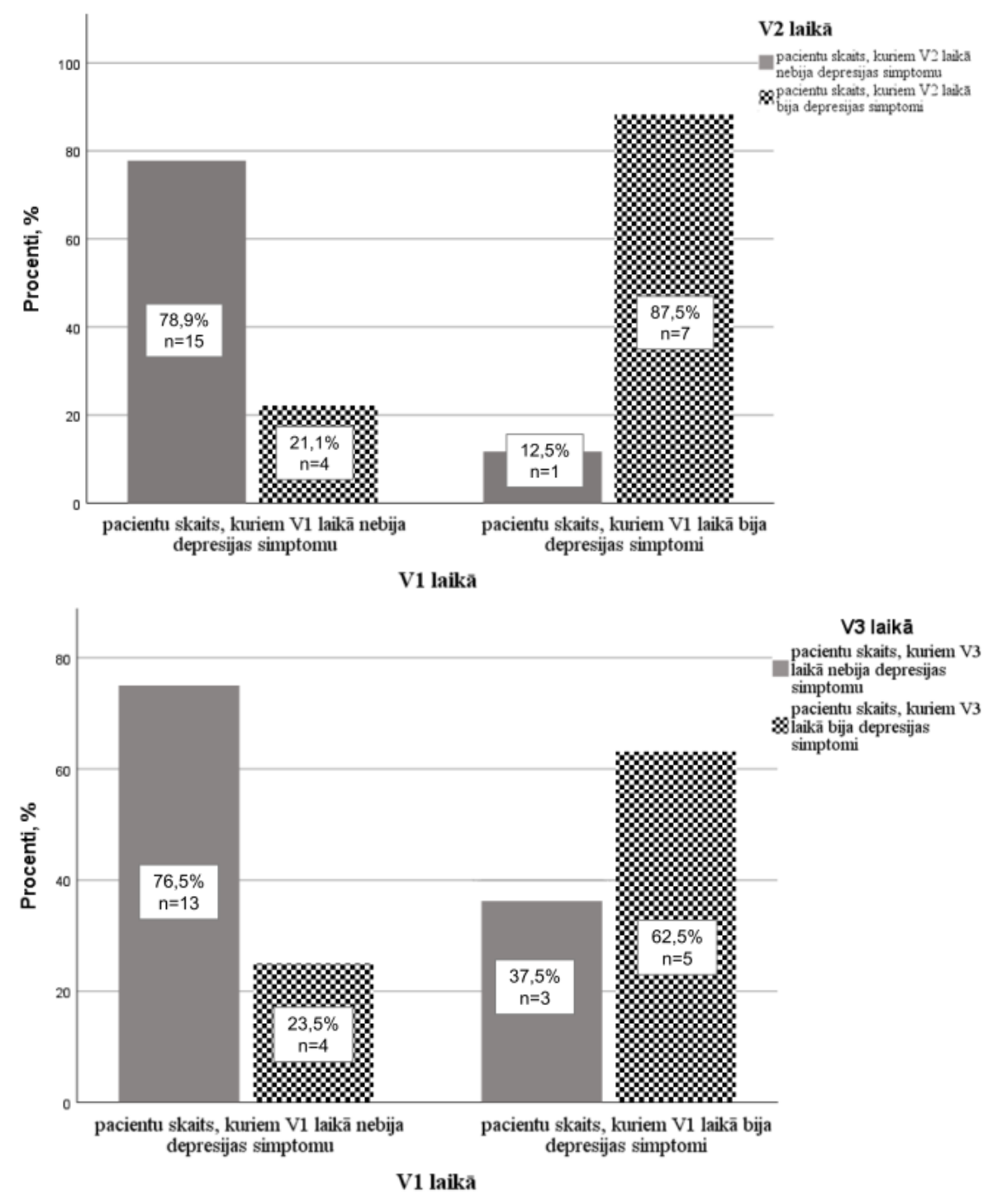

3.14. attēls. Depresijas simptomu izmaiņas pēc 6 un 12 mēnešiem pacientiem, kuriem veica angioplastiju.

\subsubsection{Depresijas simptomu biežums medikamentozās terapijas grupā}

PHQ-9 punktu skaita mediānas vērtības medikamentozās terapijas grupā pacientiem pirms $(\mathrm{Me}=6(\mathrm{IQR}: 3 ; 10))$, sešu $(\mathrm{Me}=6(\mathrm{IQR}: 3 ; 11))$ un 12 mēnešu $(\mathrm{Me}=6(\mathrm{IQR}: 3 ; 10))$ 
laika periodā statistiski nozīmīgi neatšķīrās $(p=0,64$; Kendall's $W=0,03)$. Analizējot pacientu skaitu, kuriem bija depresijas simptomi pirms, 6 un 12 mēnešu periodā, būtiski nemainījās $(p=0,819 ;$ Kendall's $W=0,013)$. Līdzīgi statistiski nozīmīgas atšķkirības starp vizītēm netika atrastas ( $p=0,779 ;$ Kendall's $W=0,017)$, ja depresijas noteikšanai izmantoja PHQ-9 kritērijus, kas atbilst rekurentiem depresīviem traucējumiem vai subklīniskai depresijai. Depresijas simptomu sastopamības izmaiņas gada laikā pacientiem ar nozīmīgu miegaartērijas stenozi, kuri saṇēma tikai medikamentozu terapiju, atspoguḷotas 3.15. attēēā.

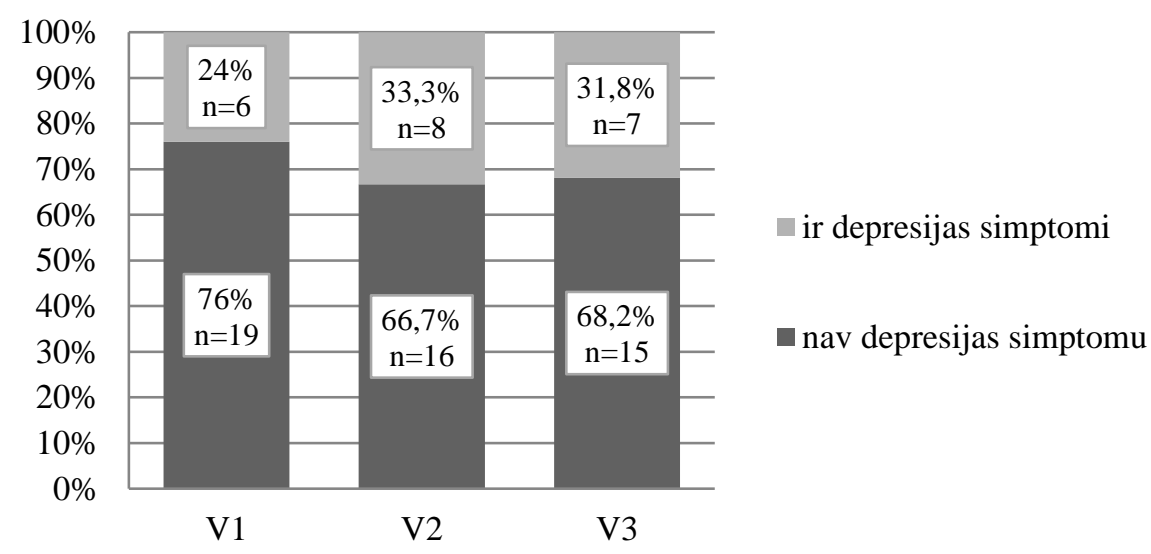

3.15. attēls. Depresijas simptomi medikamentozās terapijas grupā 6 un 12 mēnešu laika periodā

Analizējot depresijas simptomu izmaiņas pēc 6 mēnešiem, tiem pacientiem, kuriem sākotnēji bija depresijas simptomi $(n=6)$, četriem pacientiem tie saglabājās $(66,7 \%)$, bet 2 pacientiem tos vairs nenovēroja (33,3\%). Š̄ atšksirība nebija statistiski nozīmīga $(p=0,687)$. Līdzīgs depresijas simptomu biežums saglabājas arī pēc gada, tas ir, pieciem pacientiem depresijas simptomi saglabājās $(71,4 \%)$, bet 2 pacientiem tos vairs nenovēroja $(28,6 \%)$, ( $p=0,243)$. Jāatzīmē, ka no tiem pacientiem, kuriem sākotnēji nebija depresijas simptomi (n = 18), tie parādījās 4 pacientiem $(22,2 \%)$ pēc 6 mēnešiem, bet pēc gada depresijas simptomi tika diagnosticēti 2 pacientiem no 15 pacientiem, kuriem sākotnēji tie nebija. Depresijas simptomu izmaiņas pēc 6 un 12 mēnešiem pacientiem medikamentozās terapijas grupā atspoguḷotas 3.16. attēlā. 


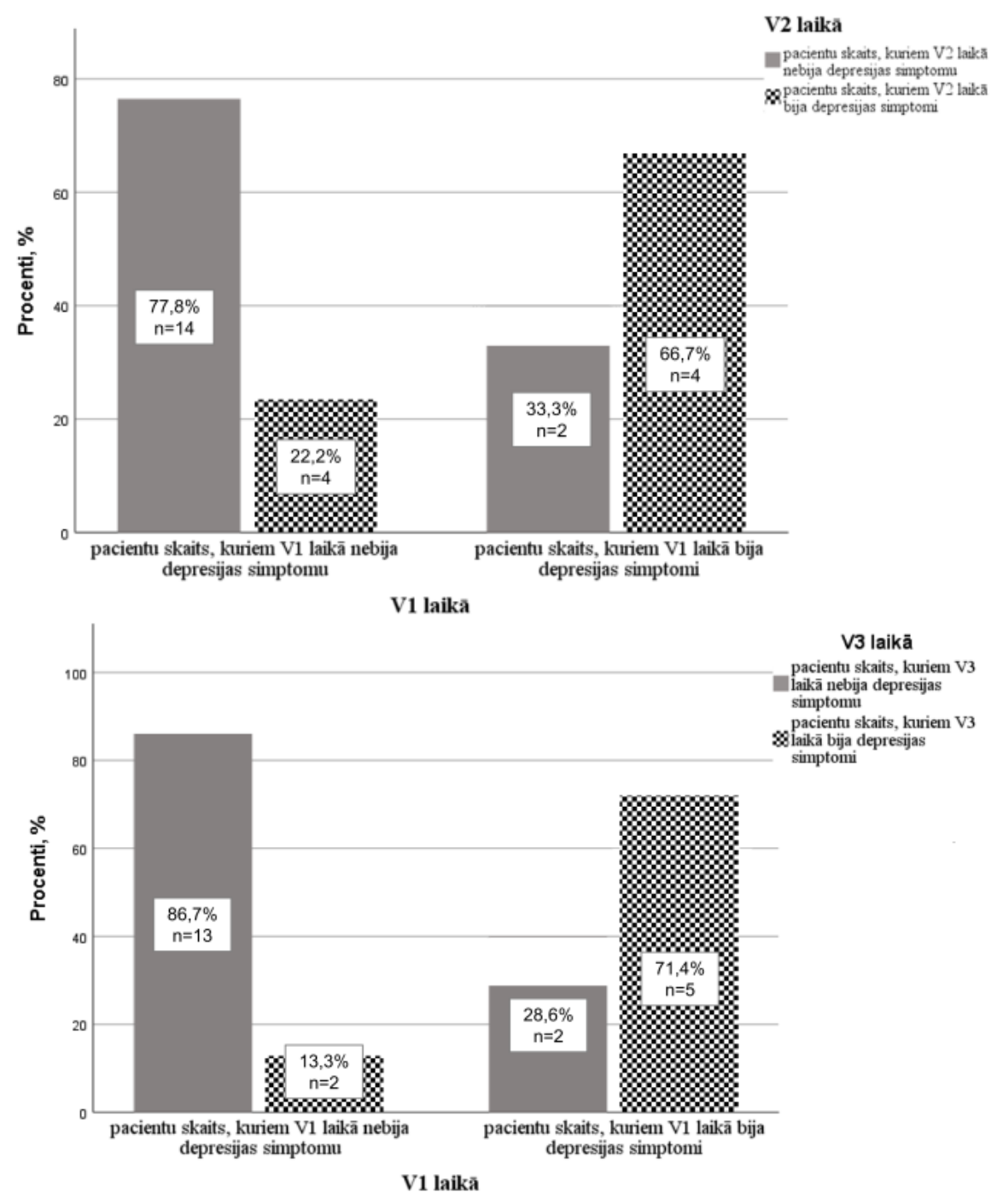

3.16. attēls. Depresijas simptomu izmaiņas pēc 6 un 12 mēnešiem medikamentozās terapijas grupā

Apkopojot 3.5.2., 3.5.3., 3.5.4. apakšnodaļās minēto, pacientiem, kuriem sākotnēji bija depresijas simptomi, nedaudz vairāk kā pusei pacientu tie mazinājās pēc MEA, bet pēc PTA vai medikamentozās terapijas depresijas simptomu mazināšanos nevēroja. Taču šĩs izmaiņas nebija statistiski nozīmīgas.

\subsubsection{Depresijas simptomu analīze pacientiem, kuriem veica miega artērijas endarterektomiju}

Lai noteiktu, vai kāds no klīniskiem parametriem varētu būt asociēts ar depresijas simptomu izzušanu, saglabāšanos vai parādīšanos no jauna, tika analizēti pacienti, kuriem depresijas simptomi bija pirms revaskularizācijas, kā arī pacienti, kuriem tos novēroja tikai pēc nozīmīgas miega artērijas ārstēšanas uzsākšanas. Depresijas simptomu analīze PTA+MT un MT grupās netika veikta mazā pacienta skaita dēḷ. 


\subsubsection{Pacienti ar depresijas simptomiem pirms endarterektomijas}

Tā kā nevienā no pētāmām grupām statistiski nozīmīgas atšķirības depresijas simptomu biežumā starp 6 un 12 mēnešiem netika novērotas, tad analizēti tika tie pacienti, kuriem pirms MEA novēroja depresijas simptomus, bet pēc 12 mēnēšiem tie vai nu vairs nebija vai saglabājās.

No 128 MEA+MT grupas pacientiem, 27 bija depresijas simptomi pirms endarterektomijas. No šiem 27, 16 pacientiem ( 9 vīriešiem $(60 \%)$ un 7 sievietēm $(58,3 \%)$ ) pēc 12 mēnešiem depresijas simptomi vairs netika novēroti, savukārt 11 pacientiem (6 vīriešiem $(40 \%)$ un 5 sievietēm $(41,7 \%))$ tie saglabājās. Statistiski nozīmīgas atšķirības depresijas simptomu sastopamības izmain̄ās starp abiem dzimumiem netika novērotas $(p<0,99$, Cramer's $V=0,012)$. Depresijas simptomu izmaiņas gada laikā atkarībā no dzimuma MEA+MT grupā atspogulototas 3.17. attēlā.

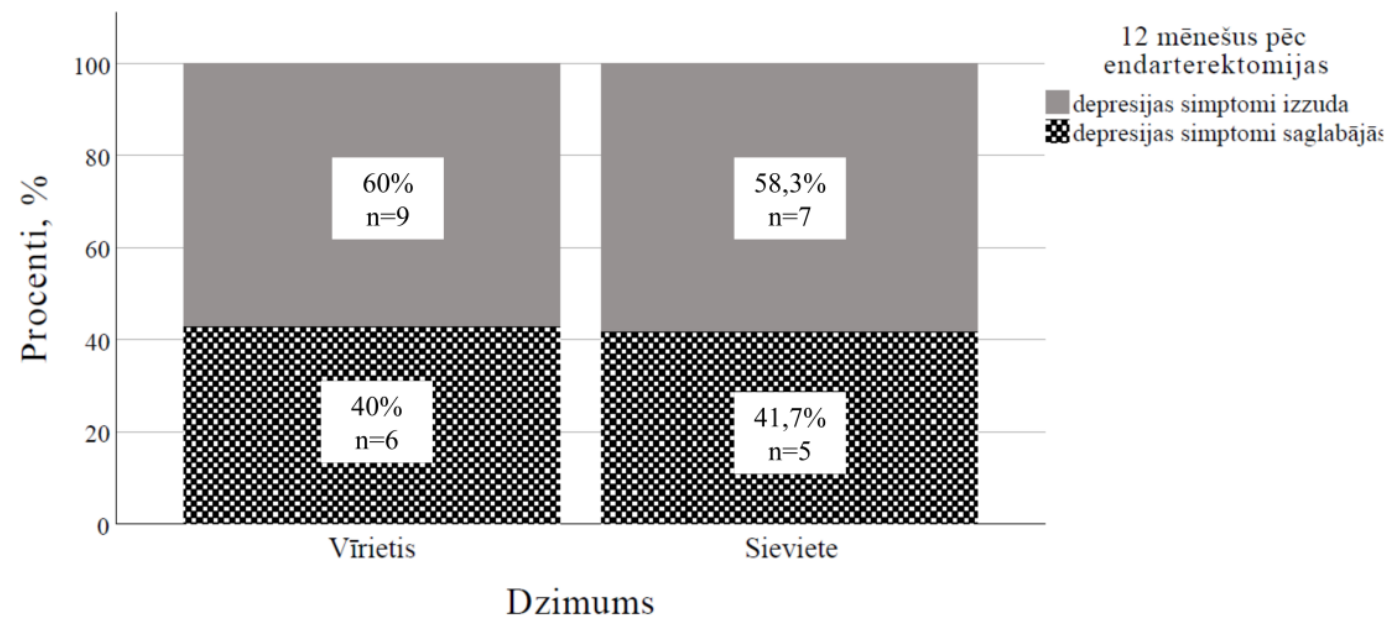

3.17. attēls. Depresijas simptomu izmaiṇas atkarībā no dzimuma

Vecuma mediānas vērtība bija līdzīga starp pacientiem, kuriem saglabājās $(\mathrm{Me}=71$ $(\mathrm{IQR}:$ 63;75)) vai izzuda $(\mathrm{Me}=70(\mathrm{IQR}$ : 62;75)) depresijas simptomi gada laikā pēc miega artērijas endarterektomijas $(p=0,598 ; r=0,046)$.

Nosakot, vai blakusslimību skaits varētu būt saistīts ar depresijas saglabāšanos gadu pēc MEA, novēroja tendenci, ka depresijas simptomi saglabājas biežāk tiem pacientiem, kuriem bija vairāk blakussaslimšanu, tomēr šì saistība nebija statistiski nozīmīga $(p=0,729$, Cramer's $V=0,4)$. Blakussaslimšanu grupā tika iekḷautas KSS, MA, HSM sākot ar III funkcionālo klasi pēc NYHA, AH sākot ar 2. pakāpi, PAS, CD, HNS sākot ar 3. pakāpi, sāpes, vairogdziedzera hipo- vai hiperfunkcija, nopietni redzes traucējumi, hroniskas plaušu slimības, audzējs anamnēzē. ĶMI mediānas vērtība arī statistiski nozīmīgi neatšķīrās starp 
pacientiem, kuriem depresijas simptomi saglabājās (Me = 25,64 (IQR: 21,5;28,42)) un tiem pacientiem, kuriem depresijas simptomi izzuda ( $\mathrm{Me}=27,1(\mathrm{IQR}: 24,57 ; 29,76)), p=0,231$, $r=0,106$. Depresijas simptomu izmaiņu saistība ar blakusslimību skaitu gada laikā atspoguḷota 3.18. attēlā.

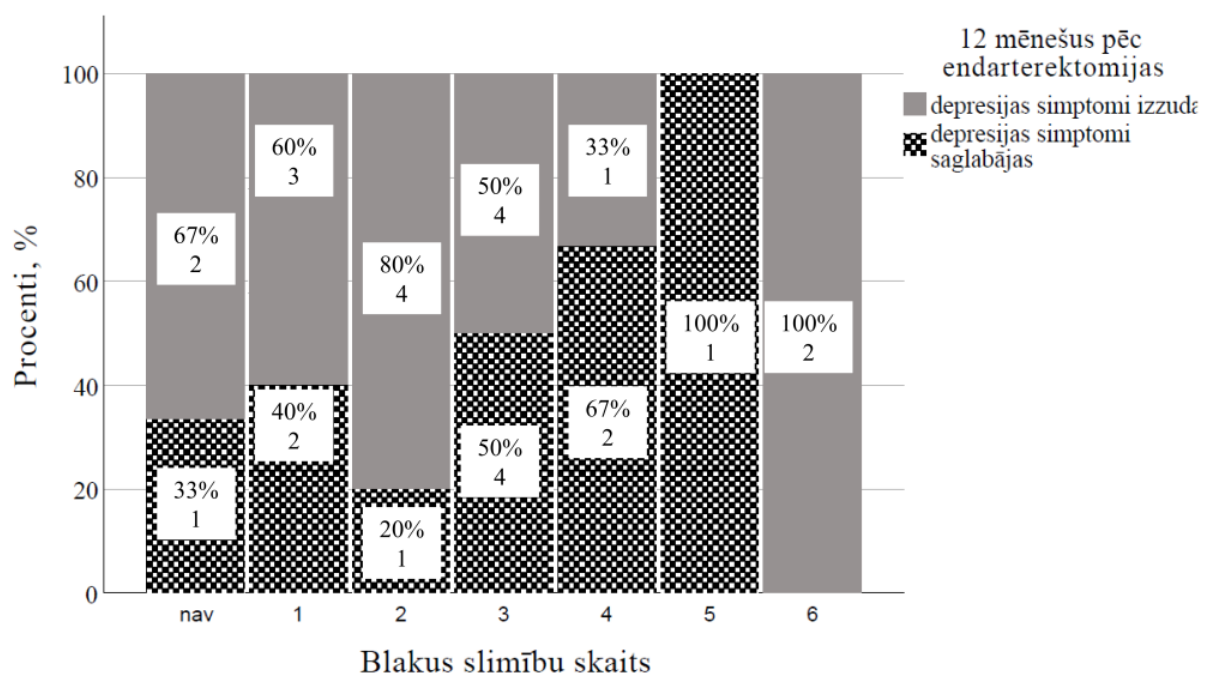

3.18. attēls. Depresijas simptomu saistība ar blakusslimību skaitu

Šajā pētījumā tika analizēta saistība starp depresijas simptomu saglabāšanos un simptomātisku miega artērijas stenozi. No 16 pacientiem, kuriem depresijas simptomi izzuda, simptomātiska artērija bija 3 pacientiem. Savukārt no 11 pacientiem, kuriem tie saglabājās, simptomātiska miega artērijas stenoze bija diviem cilvēkiem. Statistiki nozīmīgu simptomātiskas artērijas saistību ar depresijas simptomu saglabāšanos pierādīt neizdevās ( $p>0,99$, Cramer's $V=0,023)$.

Depresijas simptomu saglabāšanās vai izzušanas saistību ar otras miega artērijas stenozes pakāpi, ko novērtēja, veicot duplekss USG kontroli pēc 12 mēnešiem, nenovēroja. Katrā grupā bija pa 1 pacientam, kam bija nozīmīga otras miega artērijas stenoze $(p>0,99$, Cramer's $V=0,175)$. Nosakot vai restenoze biežāk bija pacientiem, kuriem depresijas simptomi saglabājās, nevienam no šiem pacientiem, restenozi pēc 12 mēnešiem nenovēroja $(p>0,05)$.

Trīs pacientiem novēroja lokālas paliekošas komplikācijas - dizestēziju rētas rajonā - pēc miega artērijas endarterektomijas. Visi pacienti atradās tajā grupā, kurā depresijas simptomi saglabājās pēc 12 mēnešiem ( $p=0,07$, Cramer's $V=0,417)$.

Šajā pētījumā tika analizēti arī MoCAtesta kopējās kognitīvās funkcijas relatīvās izteiktības mediānas vērtību atšķirības pacientiem, kuriem saglabājās vai izzuda depresija simptomi gada laikā. Pacientiem, kuriem depresija saglabājās, kopējā MoCA skalas punktu relatīiās izteiktības vērtība bija zemāka $(\mathrm{Me}=0(\mathrm{IQR}:-0,714 ; 0,27))$ nekā pacientiem, 
kuriem depresijas simptomi vairs netika novēroti (Me =0,076 (IQR: 0;0,132)). Šī kopējās MoCA skalas punktu relatīvās izteiktības vērtība netieši norāda, ka depresija saglabājas tiem pacientiem, kuriem kognitīvā funkcija vai nu nemainījās, vai kḷuva sliktāka, tomēr šīs atšķirības nebija statistiski nozīmīgas ( $p=0,368 ; r=0,08)$.

Iegūtie rezultāti norāda, ka neviens no analizētajiem klīniskajiem parametriem nav saistīts ar depresijas simptomu saglabāšanos vai izzušanu, izṇemot to, ka depresijas simptomi biežāk saglabājās pacientiem ar vairākām blakussaslimšanām un tiem, kuriem kognitīvās funkcija gada laikā nemainījās vai palika sliktāka, taču saistības nebija statistiski ticamas.

\subsubsection{Pacienti ar depresijas simptomiem pēc endarterektomijas}

Analizējot tos pacientus, kuriem pirms revaskularizācijas vai uzsākot pētījumu depresijas simptomi nebija, bet tos novēroja pēc 6 vai 12 mēnešiem, tad statistiski nozīmīgas atšķirīibas starp 6 un 12 mēnešiem netika konstatētas, tas ir, pacientu skaits, kuriem pēc 6 mēnešiem novēroja pirmreizēju depresijas epizodi bija līdzīgs pacientu skaitam, kam depresijas simptomi saglabājās arī pēc 12 mēnešiem. MEA+MT grupā tika analizēts tikai 12 mēnešu periods.

Iepriekš tika aprakstīts, ka 101 pacientiem, kuriem sākotnēji depresijas simptomi nebija, no tiem 11 pacientiem pēc 12 mēnešiem tie tika novēroti. Veicot šo pacientu raksturlielumu izpēti, secināja, ka vairāk bija sievietes nekā vīrieši, kurām no jauna tika novērota depresijas simptomu epizode pēc 12 mēnešiem ( $p=0,017$, Cramer's $V=0,239)$ (3.19. attēls).

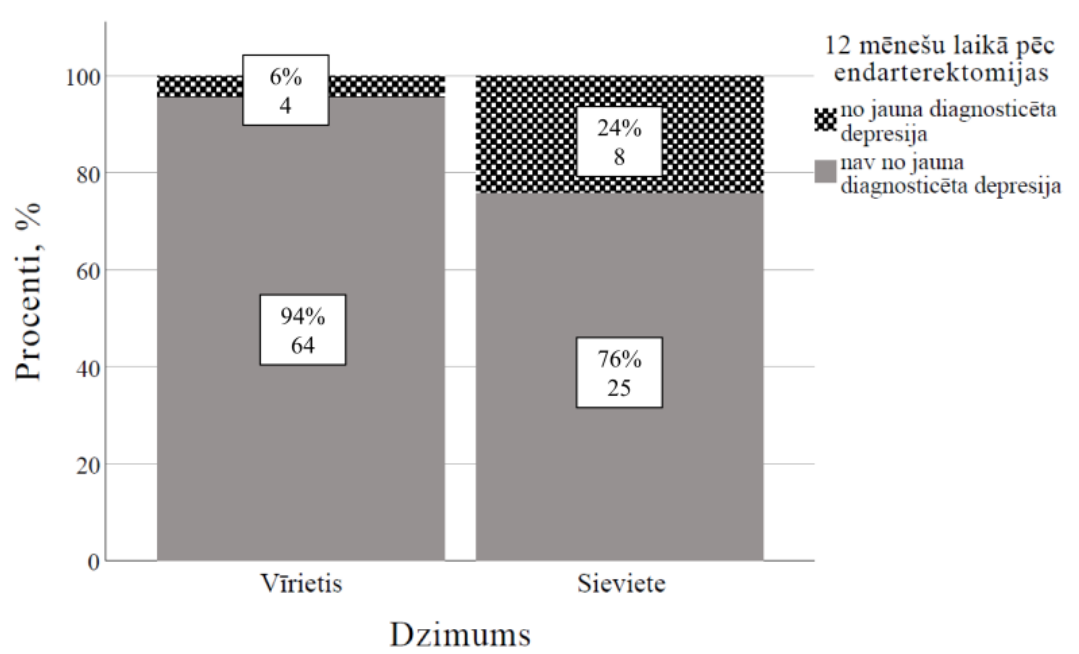

3.19. attēls. No jauna diagnosticētu depresijas simptomu sadalījums pa dzimumiem 
Analizējot, vai depresijas epizodes parādīšanās varētu būt saistîta ar vecumu, tad vecuma mediānas vērtības pacientiem, kuriem depresijas simptomus diagnosticēja tikai pēc 12 mēnešiem (Me = 70 (IQR: 62;75) un pacientiem, kuriem tā arī tie 12 mēnešu periodā netika novēroti (Me = 70 (IQR: 66;74), statistiski nozīmīgi neatšks̄īās $(p=0,941, r=0,007)$.

Tika novērota blakusslimību skaita saistība ar depresijas simptomu epizodes parādīšanos pēc 12 mēnešiem pacientiem, kuriem pirms endarterektomijas tie nebija. Pirmreizējas depresijas simptomu epizodes sastopamība palielinājās biežāk tiem, kuriem bija vairāk blakussaslimšanu, tomēr šī atšķirība nebija statistiski nozīmīga $(p=0,777$, Cramer's $V=0,134)$. Blakussaslimšanu grupā tika iekl̦autas KSS, MA, HSM sākot ar III funkcionālo klasi pēc NYHA, AH sākot ar 2. pakāpi, PAS, CD, HNS sākot ar 3. pakāpi, sāpes, vairogdziedzera hipo- vai hiperfunkcija, nopietni redzes traucējumi, hroniskas plaušu slimības, audzējs anamnēzē. Pirmreizējas depresijas simptomu epizodes biežums atkarībā no esošo blakusslimību skaita pēc MEA atspoguḷota 3.20. attēlā.

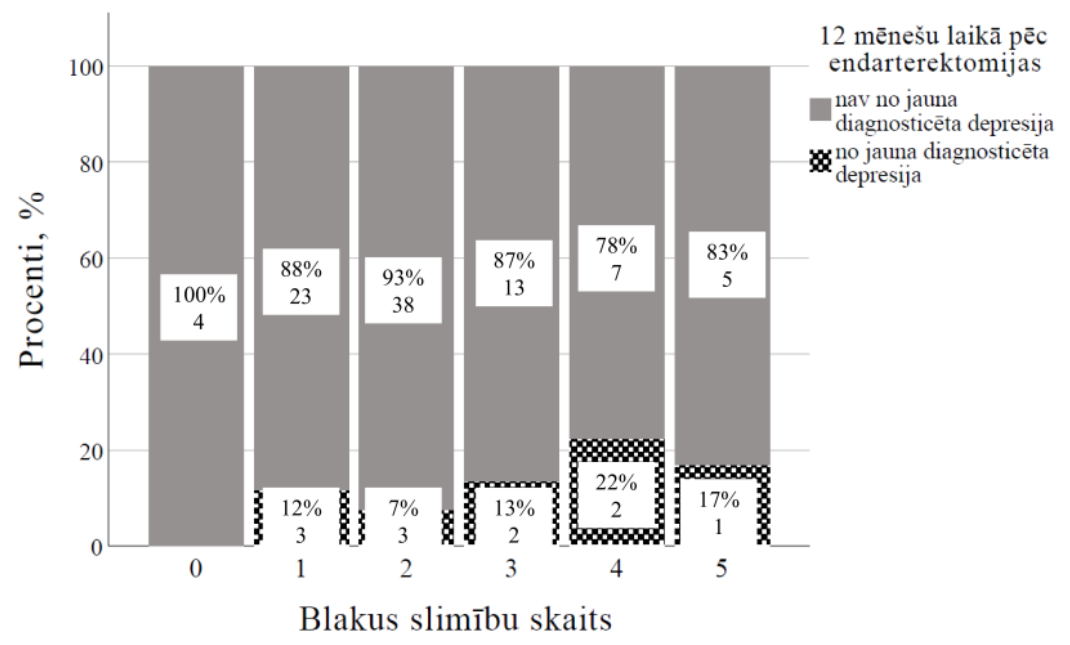

3.20. attēls. Pirmreizējas depresijas epizodes biežums atkarībā no esošo blakusslimību skaita

Analizējot arī atsevišķki katras blakussaslimšanas saistību ar pirmreizējas depresijas simptomu epizodi, statistiski nozīmīgas atšķirības starp konkrēto slimību un depresijas simptomu parādīšanos netika novērotas $(p>0,05)$. Nosakot, vai ir atšķirības ĶMI mediānas vērtībās starp pacientiem, kuriem pēc 12 mēnešiem tika diagnosticēta pirmreizējas depresijas epizode, un pacientiem, kuriem 12 mēnešu periodā depresijas simptomi netika konstatēti, tika novērots, ka pacientiem, kuriem bija pirmreizējas depresijas simptomu epizode, ĶMI bija lielāks (Me = 29,35 (IQR: 25,39;30,8) nekā pacientiem, kuriem depresija netika konstatēta $(\mathrm{Me}=26,64$ (IQR: 24,22; 29,41). Tomēr š̄i atšķirība nebija statistiski nozīmīga $(p=0,121$; $r=0,141)$. 
Simptomātiska miega artērijas stenoze (pieciem (45,5\%) no 11 pacientiem) biežāk bija pacientiem, kuriem pirmreizējas depresijas simptomu epizode tika novērota pēc 12 mēnešiem nekā pacientiem, kuriem depresijas simptomi netika novēroti (29 (32,2\%) no 90 pacientiem). Tomēr šī atšķirība nebija statistiski nozīmīga ( $p=0,165$, Cramer's $V=0,129)$.

Nosakot, vai pirmreizējas depresijas epizodes simptomu parādīšanās bija saistīta ar otras miega artērijas stenozes pakāpi, kas tika novērtēta, veicot duplekss USG kontroli pēc 12 mēnešiem, konstatēja, ka trim no 90 pacientiem (3,3\%), kuriem depresija 12 mēnešu periodā netika diagnosticēta, bija otras artērijas nozīmīga stenoze un pieciem pacientiem (5\%) - otras artērijas oklūzija. Savukārt no 11 pacientiem, kuriem 12 mēnešu laikā pēc endarterektomijas tika diagnosticēta pirmreizēja depresijas simptomu epizode, vienam pacientam $(9,1 \%)$ bija attiecīgi $\geq 70 \%$ otras miega artērijas stenoze un diviem pacientiem $(18,2 \%)$ - oklūzija. Lai gan procentuāli tiem, kuriem no jauna tika konstatēta pirmreizējas depresijas epizode, biežāk bija sastopama otras artērijas nozīmīga stenoze vai oklūzija, tomēr

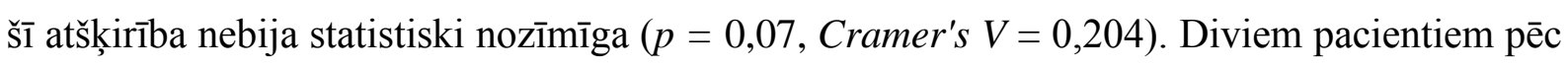
miega artērijas endarterektomijas novēroja restenozi pēc 6 mēnešiem, tomēr saistība starp restenozi un pirmreizējas depresijas simptomu epizodes parādīšanos netika pierādīta ( $p>0,99$, Cramer's $V=0,03)$.

Analizēta tika arī pēcoperācijas lokālo komplikāciju (n.laryngeus bojājuma, n.facialis vai dizestēzijas rētas rajonā) saistība ar pirmreizējas depresijas simptomu epizodes parādīšanos pēc 12 mēnešiem. Statistiski nozīmīgas atšķirības netika novērotas. Septiņpadsmit (18,9\%) no 90 pacientiem novēroja lokālas pēcoperācijas komplikācijas, kuriem depresijas simptomi netika novēroti 12 mēnešu periodā. Savukārt tiem, kuriem tika konstatēta pirmreizēja depresijas simptomu epizode, komplikācijas bija tikai vienam no 11 pacientiem $(9,1 \%),(p>0,99$, Cramer's $V=0,068)$.

Nosakot, vai kopējās MoCA skalas punktu relatīvās izteiktības vērtības bija atšķirīgas starp pacientiem, kuriem tika diagnosticēta pirmreizēja depresijas simptomu epizode un tiem, kam depresija netika konstatēta 12 mēnešu periodā, tad pacientiem, kuriem bija pirmreizēja depresijas epizode kopējās MoCA skalas punktu relatīvās izteiktības mediānas vērtība bija 0,082 (IQR: - 0,034; 0,199), bet pacientiem, kuriem depresijas simptomi netika novēroti $-\mathrm{Me}=0,071$ (IQR: $0 ; 0,136)$. Šìs atšķirības nebija statistiski nozīmīgas $(p=0,887$, $r=0,012)$.

Apkopojot iepriekšminēto, lielākā daļa klīnisko raksturlielumu nebija asociēti ar depresijas simptomu parādīšanos no jauna pēc MEA, izņemot to, ka sievietēm depresijas simptomi tomēr attīstījās biežāk nekā vīriešiem. Tādus klīniskos parametrus, kā lielāks blakusslimību skaits, simptomātiska miega artērija un otras miega artērijas nozīmīga stenoze, 
biežāk novēroja pacientiem, kuriem pēc gada attīstījas depresijas simptomi, taču š̄̄s saistības nebija statistiski ticamas.

\subsection{Ar veselību saistītās dzīves kvalitātes raksturojums}

\subsubsection{Dzīves kvalitātes raksturojums, uzsākot pētījumu}

Izvērtējot SF-36v2 rādītājus, kas atspoguḷo dažādu ar veselību saistītu dzīves kvalitātes raksturlielumu jeb domēnu vērtējumu no pacienta skata punkta, tad vidējās vērtības, kas mazākas par 50 punktiem, bija sastopamas visās grupās sekojošos domēnos: vispārējais veselības stāvoklis (MEA+MT grupā: 47,6 (17), PTA+MT grupā: 44,7 (19,5), MT grupā: 47,5 (25,6)), fiziskās veselības vispārējais stāvoklis (MEA+MT grupā: 44 (8,5), PTA+MT grupā: $39,7(8,3)$, MT grupā: 42,1 $(8,9))$ un psihiskās veselības vispārējais stāvoklis (MEA+MT grupā: 45,5 (10,1), PTA+MT grupā: 44,5 (10,9), MT grupā: 50,1 (7,8)). Turklāt SF-36v2 vidējā vērtība fiziskās veselības stāvokḷa ietekme uz iesaistīšanos darba un citās ikdienas aktivitātēs bija mazāka par 50 punktiem PTA+MT grupā $(47,7(25,7))$. Savukārt visaugstākās vērtības bija sociālās funkcijas pašnovērtējumā MEA+MT un MT grupās (3.14. tabula).

Salīdzinot dzīves kvalitāti pirms revaskularizācijas starp grupām, tad PTA+MT grupā fiziskās funkcionēšanas spējas (PF) rādītāji (53,4 (23)) bija salīdzinoši zemāki nekā abās pārējās grupās $(p=0,036)$, tomēr statistiskā efekta lielums bija mazs $\left(\eta^{2}=0,031\right)$. Veicot post-hoc analīzi, statistiski nozīmīgas atšķirības starp grupām nekonstatēja $(p>0,05)$. Arī sāpes (BP) bija izteiktākasPTA+MT grupā nekā pārējās grupās ( $p=0,009)$. Veicot post-hoc analīzi, statistiski nozīmīga atšksirība SF-36v2 vidējās vērtībās bija starp MEA+MT un PTA+MT grupām $(p=0,049)$ un starp PTA+MT un MT grupu $(p=0,006)$, tomēr šo vidējo vērtỉbu atšķirību statistiskais efekts bija mazs $\left(\eta^{2}=0,044\right)$. Vidējās SF-36v2 vērtības pacientiem ar nozīmīgu miega artērijas stenozi pirms revaskularizācijas atspoguļotas 3.14. tabulā.

3.14. tabula

Vidējās SF-36v2 vērtības pacientiem ar nozīmīgu miega artērijas stenozi pirms revaskularizācijas

\begin{tabular}{lccccc} 
& $\begin{array}{c}\text { MEA+MT } \\
(\mathbf{n = 1 5 9 )}\end{array}$ & $\begin{array}{c}\text { PTA+MT } \\
(\mathbf{n = 2 9})\end{array}$ & $\begin{array}{c}\text { MT } \\
(\mathbf{n = 2 5})\end{array}$ & $\begin{array}{c}\boldsymbol{p} \\
\text { vērtība }\end{array}$ & $\begin{array}{c}\text { Efekta } \\
\text { lielums } \\
\boldsymbol{\eta}^{\mathbf{2}}\end{array}$ \\
\hline $\begin{array}{l}\text { Fiziskās funkcionēšanas } \\
\text { spējas (PF) }\end{array}$ & $66,6(22,4)$ & $53,4(23)$ & $57(30)$ & $0,036^{*}$ & 0,031
\end{tabular}


3.14. tabulas turpinājums

\begin{tabular}{|c|c|c|c|c|c|}
\hline & $\underset{(\mathbf{n}=159)}{\text { MEA+MT }}$ & $\begin{array}{c}\text { PTA+MT } \\
(\mathbf{n}=\mathbf{2 9})\end{array}$ & $\begin{array}{c}\text { MT } \\
(n=25)\end{array}$ & $\underset{\text { vērtība }}{p}$ & $\begin{array}{c}\text { Efekta } \\
\text { lielums } \\
\eta^{2} \\
\end{array}$ \\
\hline $\begin{array}{l}\text { Fiziskā veselības stāvokḷa } \\
\text { ietekme uz darbu un citām } \\
\text { ikdienas aktivitātēm (RP) }\end{array}$ & $55,4(26,7)$ & $47,7(25,7)$ & $57,1(27,4)$ & 0,158 & 0,017 \\
\hline Sāpes (BP) & $60(27)$ & $48,4(27,2)$ & $66,7(26,4)$ & $0,009 *$ & 0,044 \\
\hline $\begin{array}{l}\text { Vispārējais veselības } \\
\text { stāvoklis }(\mathrm{GH})\end{array}$ & $47,6(17)$ & $44,7(19,5)$ & $47,5(25,6)$ & 0,297 & 0,015 \\
\hline Vitalitāte (VT) & $56,7(18,6)$ & $49,7(20,7)$ & $60,4(20,1)$ & 0,173 & 0,017 \\
\hline Sociālā funkcija (SF) & $71,7(25,3)$ & $65,1(27,2)$ & $75,8(19,2)$ & 0,671 & 0,004 \\
\hline Emocionālais stāvoklis (RE) & $65(27,7)$ & $57,9(27,3)$ & $71,7(23,1)$ & 0,231 & 0,014 \\
\hline Psihiskā veselība $(\mathrm{MH})$ & $63,5(17,5)$ & $62,6(21,7)$ & $71,3(15)$ & 0,238 & 0,014 \\
\hline $\begin{array}{l}\text { Fiziskās veselības vispārējais } \\
\text { stāvoklis (PCS) }\end{array}$ & $44(8,5)$ & $39,7(8,3)$ & $42,1(8,9)$ & 0,09 & 0,023 \\
\hline $\begin{array}{l}\text { Psihiskās veselības } \\
\text { vispārējais stāvoklis (MCS) }\end{array}$ & $45,5(10,1)$ & $44,5(10,9)$ & $50,1(7,8)$ & 0,285 & 0,012 \\
\hline
\end{tabular}

Apkopojot iepriekšminēto, PTA+MT grupā bija sliktākas fiziskās funkcionēšanas spējas un izteiktākas sāpes nekā pārējās pētāmās grupās, taču jāatzīmē, ka statistisko atš̌şirību efekta lielums bija mazs.

\subsubsection{Dzīves kvalitātes saistība ar klīniskiem raksturlielumiem}

Nedalot pacientus grupās, bet analizējot kopā visus pacientus ar nozīmīgu miega artērijas stenozi pirms ārstēšanas uzsākšanas, novēroja statistiski nozīmīgu, bet vāju negatīva korelācija starp vecumu un fiziskās veselības vispārējo stāvokli $\left(\mathrm{r}_{\mathrm{s}}=-0,174, p=0,011\right.$; 95\%TI - 0,301; - 0,041). Kā arī, statistiski nozīmīgu vāju negatīvu korelācija starp vecumu un psihiskās veselības vispārējo stāvokli $\left(\mathrm{r}_{\mathrm{s}}=-0,168 ; p=0,014 ; 95 \% \mathrm{TI}-0,295 ;-0,035\right)$. Veicot viena faktora lineāro regresijas analīzi, kur atkarīgais mainīgais bija SF-36v2 PCS un MCS vidējās vērtības, bet neatkarīgais main̄̄gais bija vecums, konstatēja, ka vecums kā pazīme ietekmē fizisko vispārējo veselības stāvokli tikai 3,8\% (konstante $=56,59$, beta $=-0,2, p<0,001)$, bet psihiskās veselības vispārējo stāvokli $-2,1 \%$ (konstante $=58,14$, beta $=-0,17, p<0,001)$. Iepriekš minētās saistības atspoguḷotas 3.21. attēlā. 

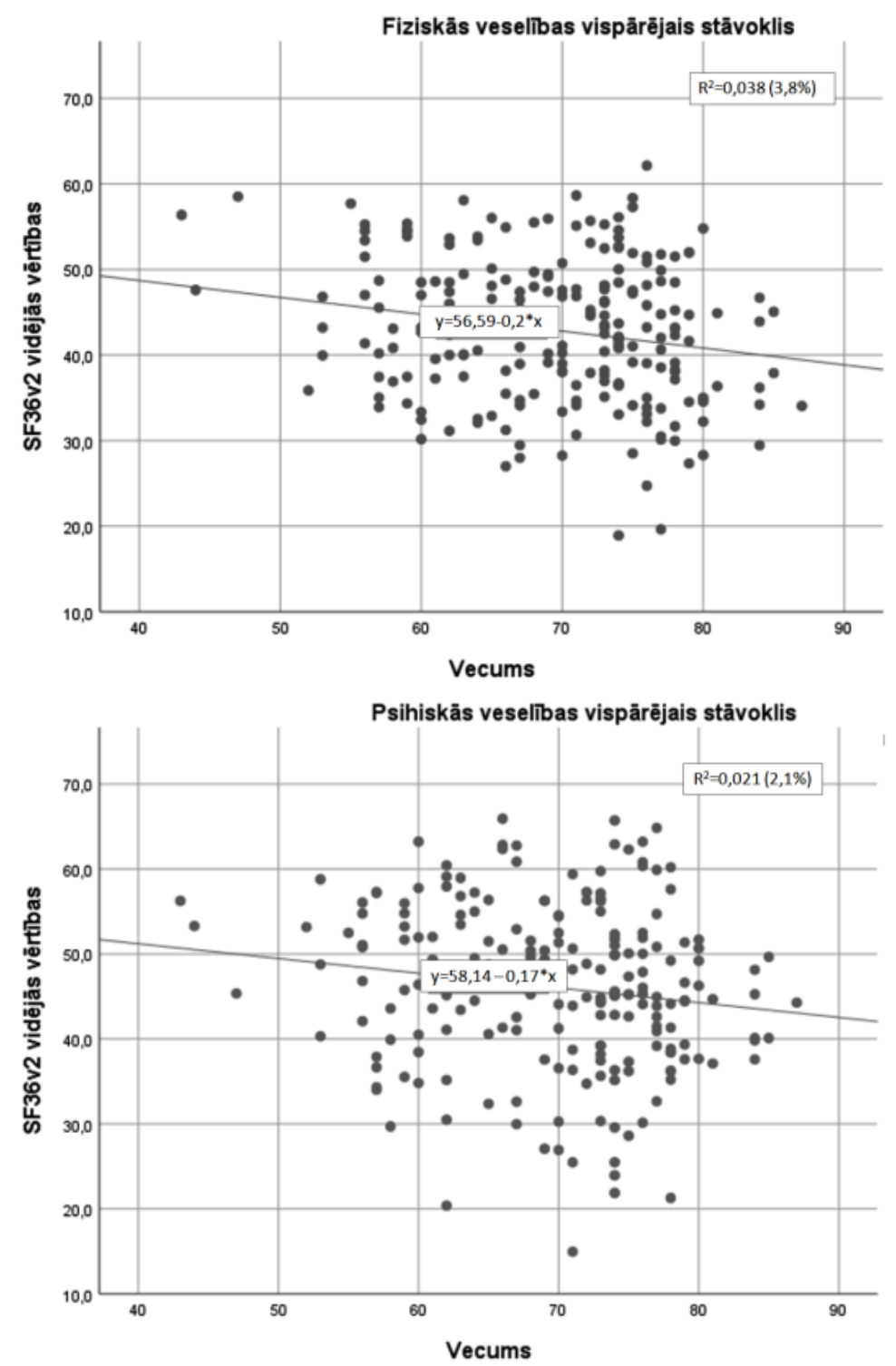

3.21. attēls. Fiziskā un psihiskā vispārējā veselības stāvokḷa korelācija ar vecumu

Līdzīgi tika novērota statistiski nozīmīga vāja negatīva korelācija starp vecumu un PF $\left(\mathrm{r}_{\mathrm{s}}=-0,197, p=0,004 ; 95 \% \mathrm{TI}-0,322 ;-0,065\right), \mathrm{RP}\left(\mathrm{r}_{\mathrm{s}}=0,235, p=0,005 ; 95 \% \mathrm{TI}-0,382\right.$; $-0,132), \mathrm{SF}\left(\mathrm{r}_{\mathrm{s}}=-0,195, p=0,004 ; 95 \% \mathrm{TI}-0,321 ;-0,063\right)$ un RE $\left(\mathrm{r}_{\mathrm{s}}=-0,222\right.$; $p=0,002 ; 95 \% \mathrm{TI}-0,337 ;-0,081)$ domēniem.

Salīdzinot SF-36v2 domēnu vidējās vērtības starp dzimumiem, tika novērots, ka sievietēm vidējās vērtības bija zemākas nekā vīriešiem sekojošos domēnos: PF $57,5(23,5)$, RP 46,4 (21,9), BP 53,4 (29,1), GH 43,4 (16), VT 54 (18,5) un PCS 40,6(7,7). Šo SF-36v2 domēnu vidējo vērtību atšķirības bija statistiski nozīmīgas $(p<0,05)$, tomēr statistiskā efekta lielums bija mazs (Cohen's $d<0,04)$.

Nosakot SF-36v2 domēnu vidējo vērtības mainību atkarībā no tā, vai pacientam ir KSS, visos SF-36v2 domēnos novēroja zemākas vērtības pacientiem, kas slimo ar KSS. Šīs 
atšķirīibas bija statistiski nozīmīgas visos domēnos $(p<0,02)$, tomēr vidējs vai liels statistiskā efekta lielums bija novērojams tikai PF, RP, GH, VT un PCS domēnos (Cohen's $d \geq 0,5$ ). SF-36v2 vidējās vērtības pacientiem ar vai bez KSS atspoguḷotas 3.22. attēlā.

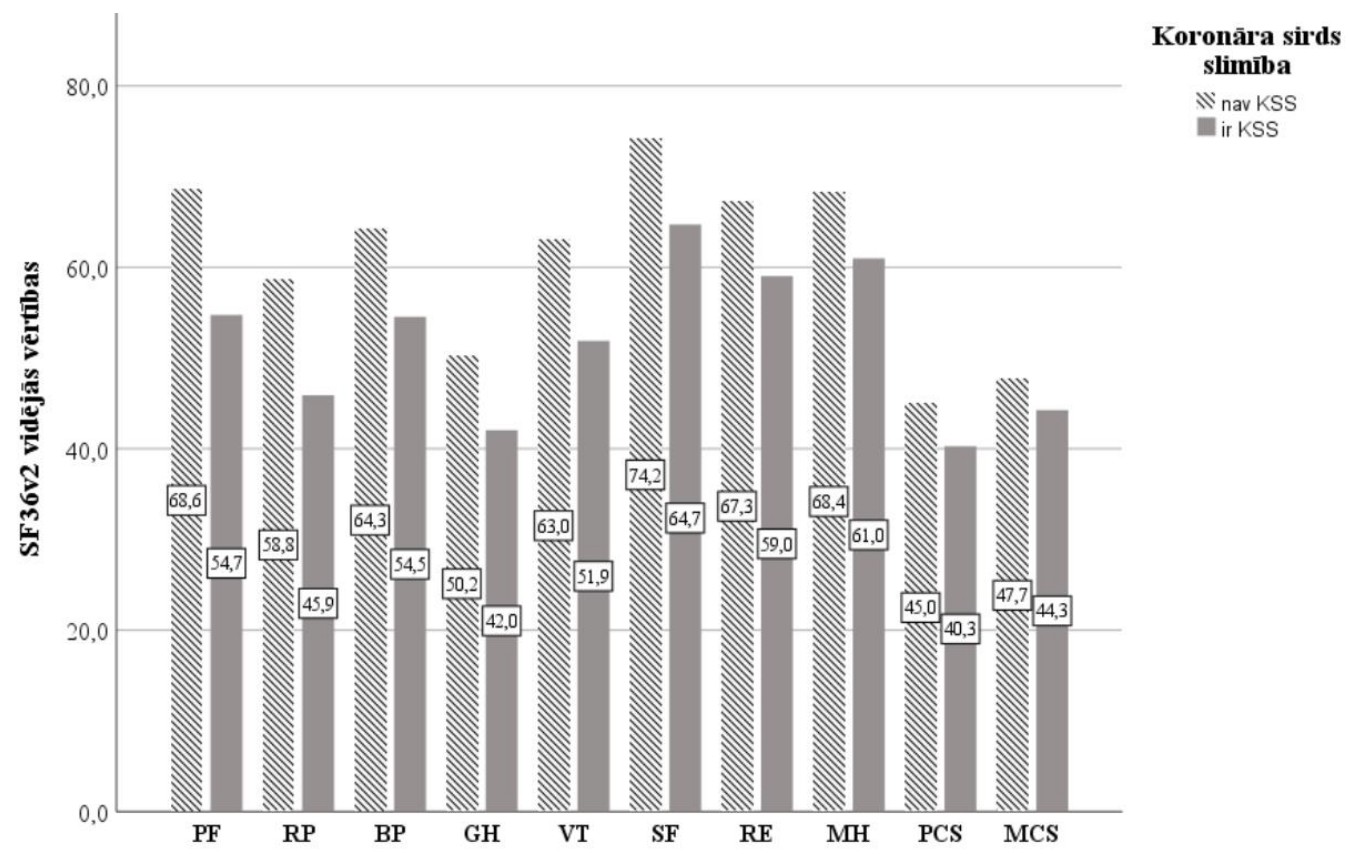

3.22. attēls. SF-36v2 vidējās vērtības pacientiem ar un bez KSS

Līdzịgi statistiski nozīmīgi zemākas SF-36v2 vidējās vērtības GH, VT un SF domēnos tika novērotas pacientiem ar cukura diabētu, tomēr statistiskā efekta lielums visos šais domēnos bija mazs ( $p<0,03$; Cohen's $d<0,04)$. SF-36v2 vidējās vērtības pacientiem ar vai bez $\mathrm{CD}$ atspoguḷotas 3.23. attēlā.

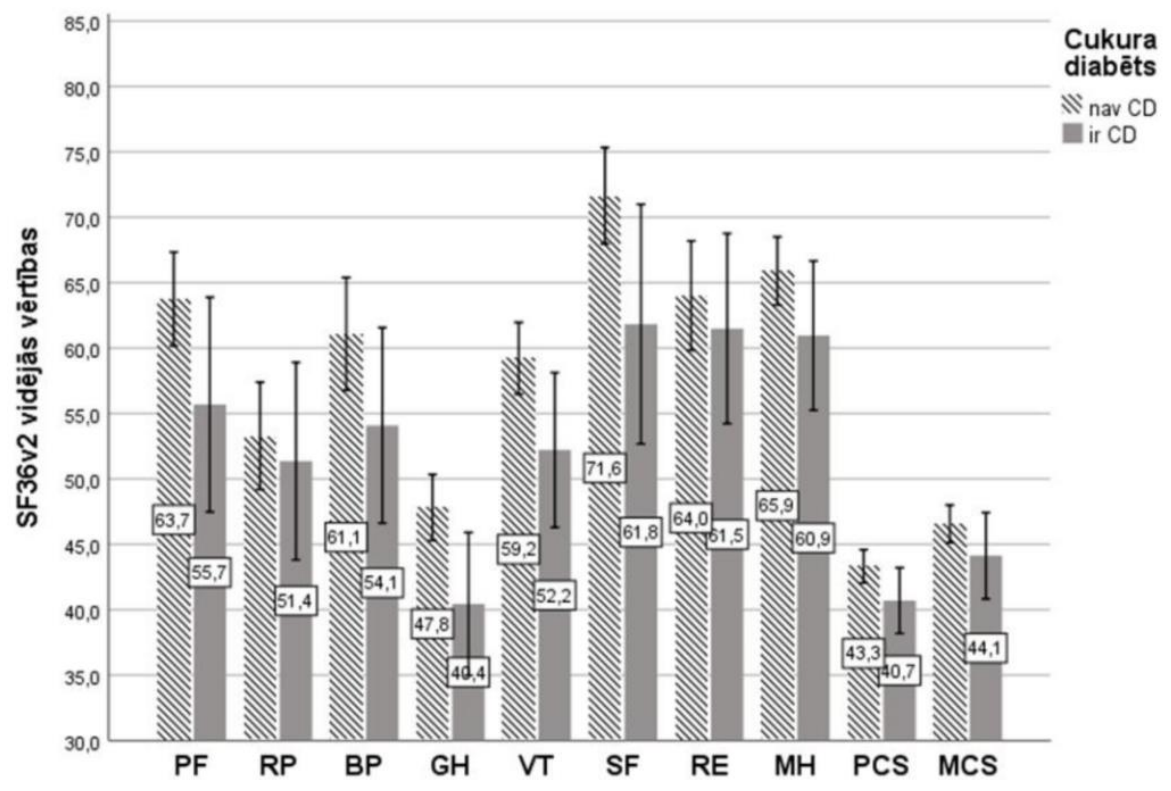

3.23. attēls. SF-36v2 vidējās vērtības pacientiem ar un bez CD 
Savukārt, SF-36v2 vidējās vērtības statistiski nozīmīgi $(p>0,05)$ nemainījās tādu blakussaslimšanu kā AH, palielināta ĶMI vai smēķēšanas dēḷ. Nosakot, vai SF-36v2 domēnu vidējās vērtības mainās atkārībā no klīniski nozīmīgas HSM ( $\geq$ III NYHA funkcionālā klase), novēroja, ka PF $(50,59(22,5))$, RP $(38,6(23,7))$, PCS $(38,16(8,4))$ vidējās vērtības bija zemākas pacientiem ar izteiktu HSM nekā pacientiem, kuriem bija HSM 0-II funkcionālā klase pēc NYHA $(p<0,04$, Cohen's $d>0,5)$. Arī pacientiem, kuriem bija MA, PF $(52,67(25,31))$, RP $(43,96(25,4))$, PCS $(39,66(8,64))$ domēnos bija statistiski nozīmīgi zemākās vērtības nekā pacientiem, kuriem MA nebija $(p<0,05)$, kā arī statistiskā efekta lielums bija vidējs PF un PCS domēnos (Cohen's $d=0,5$ ), izṇemot RP, kur statistiskā efekta lielums bija mazs (Cohen's $d=0,4)$. Pacientiem, kuriem bija PAS, bija statistiki nozīmīgi zemākas BP vidējās vērtības $(55,75 \quad(27,15))$ nekā pacientiem, kuri neslimoja ar PAS $(62,07(28,35)), p=0,05$, tomēr statisitiskā efekta lielums bija mazs (Cohen's $d=0,29)$. Savukārt analizējot SF-36v2 vidējo vērtību atšķirības atkarībā no blakusslimību skaita, konstatēja, ka palielinoties blakusslimību skaitam, samazinājās vidējās vērtības sekojošos domēnos: $\mathrm{PF}\left(p<0,001 ; \eta^{2}=0,166\right)$, RP $\left(p=0,003 ; \eta^{2}=0,101\right)$, $\mathrm{BP}\left(p=0,001 ; \eta^{2}=0,117\right)$, GH $\left(p=0,001 ; \eta^{2}=0,12\right)$, VT $\left(p=0,004 ; \eta^{2}=0,096\right)$ SF $\left(p=0,005 ; \eta^{2}=0,096\right)$ un PCS $\left(p<0,001 ; \eta^{2}=0,196\right)$.

Nosakot, vai SF-36v2 vidējās vērtības mainās atkarībā no tā, vai pacientam bija simptomātiska vai asimptomātiska miega artērijas stenoze, tad statistiski nozīmīgi zemākas vidējās vērtības bija PF $(59,97(25,09))$ un BP $(56,35(28,47))$ domēnos pacientiem, kuriem bija simptomātiska miega artērijas stenoze, tomēr statistiskā efekta lielums bija mazs (Cohen's $d=0,337$ ). Bet nosakot, vai SF-36v2 vidējās vērtības mainās atkarībā no miega artērijas stenozes puses, tas ir, vai tā ir unilaterāla vai bilaterāla, statistiski nozīmīgas atšķirīibas netika konstatētās nevienā no domēniem ( $p>0,05)$.

Nosakot saistību starp dzīves kvalitāti un kognitīvās funkcijas rādītājiem pirms revaskularizācijas, statistiski nozīmīga associācija netika pierādītas $(p>0,05)$. Tomēr nosakot SF-36v2 vidējo vērtību mainību atkarībā no tā, vai pacientam ir depresijas simptomi, konstatēja, ka visu domēnu vidējās vērtības bija zemākas pacientiem ar depresijas simptomiem ( $p<0,001$; Cohen's $d \geq 0,7)$. SF-36v2 vidējās vērtības pacientiem ar vai bez depresijas simptomiem atspoguļotas 3.24. attēlā. 


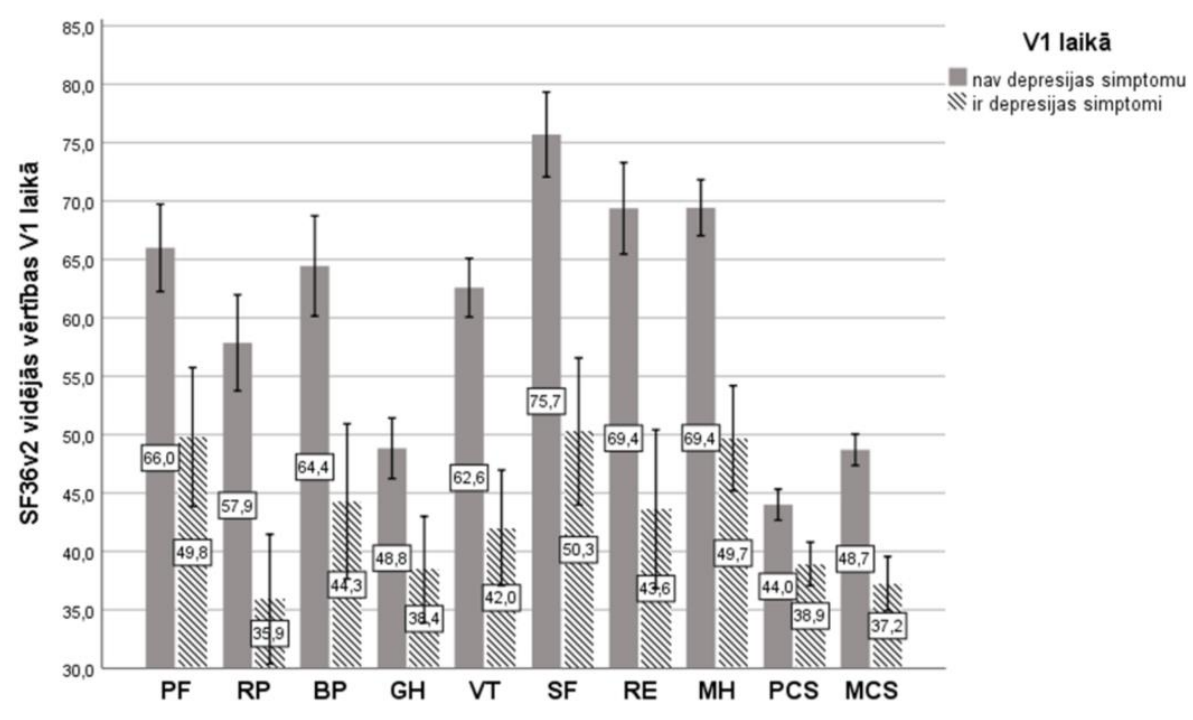

3.24. attēls. SF-36v2 vidējās vērtības pacientiem ar un bez depresijas simptomiem

Fiziskās veselības (PCS) un psihiskās veselības (MCS) vispārējā stāvokḷa novērtēšanas domēni apkopo visus 8 domēnus, kas l̦auj novērtēt fiziskās aktivitātes un psihiskās veselības ierobežojumus. Tā kā PCS un MCS domēni sniedz priekšstatu par dzīves kvalitāti, kas saistīta ar veselību, tad regresijas analīzei tika izvēlēti tieši šie domēni. Veicot daudzfaktoru logistiskās regresijas analīzi, samazināts SF-36v2 fiziskās veselības vispārējais stāvoklis (PCS $\leq 50$ punktiem) bija statistiski nozīmīgi asociēts ar KSS (OR 2,73; 95\%TI 1,$247 ; 5,974 ; p=0,012$ ) un PAS (OR 4,15; 95\%TI 1,$597 ; 10,769 ; p=0,003$ ). Logistiskās regresijas analīze faktoriem, kas asociēti ar sliktāku fiziskās veselības vispārējo stāvokli, atspoguḷota 3.15.tabulā.

3.15. tabula

Logistiskās regresijas analīze faktoriem, kas asociēti ar sliktāku fiziskās veselības vispārējo stāvokli

\begin{tabular}{|c|c|c|c|c|}
\hline \multirow[b]{2}{*}{ Faktors } & \multicolumn{2}{|c|}{ Viena faktora regresijas analīze } & \multicolumn{2}{|c|}{$\begin{array}{c}\text { Daudzfaktoru regresijas } \\
\text { analīze }\end{array}$} \\
\hline & OR $(95 \% \mathrm{TI})$ & $p$ vērtība & OR $(95 \% \mathrm{TI})$ & $p$ vērtība \\
\hline Dzimums & $2,44(1,133-5,253)$ & $0,023^{*}$ & $2,27(0,937-5,521)$ & 0,069 \\
\hline Vecums & $0,97(0,929-1,004)$ & 0,082 & & \\
\hline Simptomātiska MAS & $0,47(0,237-0,934)$ & $0,031 *$ & $0,65(0,309-1,369)$ & 0,257 \\
\hline KSS & $3,17(1,504-6,662)$ & $0,002 *$ & $2,73(1,247-5,974)$ & $0,012 *$ \\
\hline $\mathrm{CD}$ & $2,6(0,871-7,762)$ & 0,087 & & \\
\hline $\mathrm{AH}$ & $0,856(0,385-1,903)$ & 0,702 & & \\
\hline PAS & $3,551(1,421-8,877)$ & $0,007^{*}$ & $\begin{array}{c}4,15 \\
(1,597-10,769)\end{array}$ & $0,003^{*}$ \\
\hline HSM & $4,63(0,597-35,904$ & 0,142 & & \\
\hline MA & $2,68(0,775-9,278)$ & 0,12 & & \\
\hline Smēķēšana & $0,46(0,215-1,001)$ & $0,05^{*}$ & $0,58(0,237-1,416)$ & 0,231 \\
\hline ĶMI & $0,947(0,872-1,027)$ & 0,187 & & \\
\hline
\end{tabular}


Veicot daudzfaktoru loǵistiskās regresijas analīzi, lai noteiktu faktorus, kas asociēti ar psihiskās veselības vispārējo stāvokli, tika konstatēts, ka statistiski ticami tikai vecums bija saistīts ar sliktāku psihiskās veselības vispārējo stāvokli. Logistiskās regresijas analīze faktoriem, kas asociēti ar sliktāku psihiskās veselības vispārējo stāvokli atspoguļota 3.16. tabulā.

3.16. tabula

Loğistiskās regresijas analīze faktoriem, kas asociēti ar sliktāku psihiakās veselības vispārējo stāvokli

\begin{tabular}{|c|c|c|c|c|}
\hline \multirow[b]{2}{*}{ Faktors } & \multicolumn{2}{|c|}{ Viena faktora regresijas analīze } & \multicolumn{2}{|c|}{ Daudzfaktoru regresijas analīze } \\
\hline & OR (95\% TI) & $\begin{array}{c}p \\
\text { vērtība }\end{array}$ & OR (95\% TI) & $p$ vērtība \\
\hline Dzimums & $1,547(0,857-2,793)$ & 0,148 & $1,342(0,684-2,634)$ & 0,392 \\
\hline Vecums & $0,947(0,914-981)$ & $0,002 *$ & $0,956(0,918-0,995)$ & $0,028 *$ \\
\hline $\begin{array}{l}\text { Simptomātiska } \\
\text { MAS }\end{array}$ & $0,727(0,397-1,333)$ & 0,303 & & \\
\hline KSS & $1,665(0,942-2,943)$ & 0,08 & $1,307(0,704-2,426)$ & 0,396 \\
\hline $\mathrm{CD}$ & $2,097(0,936-4,701)$ & 0,072 & $2,013(0,883-4,389)$ & 0,096 \\
\hline $\mathrm{AH}$ & $1,168(0,588-2,322)$ & 0,657 & & \\
\hline PAS & $0,748(0,411-1,361)$ & 0,341 & & \\
\hline HSM & $1,971(0,62-6,271)$ & 0,25 & $1,171(0,346-3,962)$ & 0,799 \\
\hline MA & $1,183(0,523-2,675)$ & 0,687 & & \\
\hline Smēķēšana & $0,689(0,379-1,253)$ & 0,222 & $1,07(0,525-2,18)$ & 0,852 \\
\hline KMI & $1,025(0,959-1,096)$ & 0,465 & & \\
\hline
\end{tabular}

Apkopojot iepriekšminēto, tādiem klīniskiem raksturlielumiem kā vecumam, KSS, HSM sākot ar III funkcionālo klasi pēc NYHA, MA, blakus slimību skaitam un depresijas simptomu klātbūtnei bija novērota saistība ar zemākām SF-36v2 vērtībām dažādos domēnos. Veicot daudzfaktoru regresijas analīzi, sliktāks fiziskās veselības vispārējais stāvoklis bija saistīts ar KSS un PAS. Savukārt no klīniskiem faktoriem, kas asociēti ar sliktāku psihiskās veselības vispārējo stāvokli, bija vecums.

\subsubsection{Dz̄̄ves kvalitātes izmaiṇas pēc endarterektomijas}

Salīdzinot SF-36v2 vidējās vērtības MEA+MT grupā pirms endarterektomijas, 6 un 12 mēnešus pēc tās, statistiski nozīmīgas atšķirības nevienā no dzīves kvalitātes domēniem netika pierādītas. Tādu domēnu kā vispārējās veselības (GH), fiziskās (PCS) un psihiskās(MCS) veselības vispārējo stāvokḷu novērtējuma vidējās vērtības saglabājās līdzīgas arī pēc 6 un 12 mēnešiem. Kā arī augstākā vērtība, kura bijasociālās funkcijas (SF) 
pašnovērtējumā (> 70 punktiem), saglabājās nemainīga gada laikā. Visu SF-36v2 domēnu izmaiṇas gada laikā atspoguḷotas 3.25.attēlā. Kā arī, katras vizītes SF-36v2 domēnu vidējās vērtības pacientiem pēc endarterektomijas atspoguḷotas 6. pielikumā.

\subsubsection{Dz̄̄ves kvalitātes izmaiṇas pēc perkutānās transluminālās angioplastijas un stentēšanas}

Salīdzinot SF-36v2 vidējās vērtības PTA+MT grupā pirms angioplastijas, 6 un 12 mēnešus pēc tās, statistiski nozīmīgas atšķirības nevienā no dzīves kvalitātes domēniem netika pierādītas, izṇemot sāpju (BP) novērtējumā ( $\left.p=0,028, \eta^{2}=0,343\right)$, kur pirms revaskularizācijas SF-36v2 sāpju domēna vidējā vērtība bija 48,4 (27,2), pēc 6 mēnešiem - 54,3 (30), savukārt pēc 12 mēnešiem - 45,2 (17,8). Veicot post-hoc analīzi, SF-36v2 vidējā vērtība pēc 12 mēnešiem statistiski nozīmīgi bija mazāka nekā SF-36v2 BP vidējā vērtība pēc 6 mēnešiem $(p=0,024)$. Vidējās SF-36v2 vērtības mazākas par 50 punktiem saglabājās nemainīgas visā novērošanas periodā attiecīgajos domēnos: fiziskās veselības stāvokḷa ietekmes uz iesaistǐšanos darbā un citās aktivitātēs (RP), GH, vitalitātes (VT), PCS un MCS novērtējumā. Divpadsmit mēnešus pēc revaskularizācijas samazinājās SF-36v2 vidējās vērtības (kḷuva mazākas par 50 punktiem) fiziskās funkcionēšanas (PF) pašnovērtējumā. Savukārt visaugstākās SF-36v2 vidējās vērtības (lielākas par 70 punktiem) pirms angioplastijas bija SF domēnā, kur pēc 6 mēnešiem tā bija 70,4 (30,4), toties pēc 12 mēnešiem kḷuva ievērojami zemāka $(57,2(30,4))$. Visu SF-36v2 domēnu izmaiņas gada laikā atspoguḷotas 3.25.attēlā. Kā arī, katras vizītes SF-36v2 domēnu vidējās vērtîbas pacientiem pēc angioplastijas atspoguļotas 7. pielikumā.

\subsubsection{Dzīves kvalitātes izmaiņas medikamentozās terapijas grupā}

Salīdzinot SF-36v2 vidējās vērtības MT grupā pētījuma sākumā un 6, 12 mēnešu novērošanas periodā, statistiski nozīmīgas atšķirības tika konstatētas RP domēnā ( $p=0,039$, $\left.\eta^{2}=0,392\right)$, kur uzsākot pētījumu, šī SF-36v2 vidējā vērtība bija visaugstākā $(57,1(27,4))$, bet pēc 6 un 12 mēnešiem tā bija zemāka (attiecīgi 34,6(20,4) un 37,5(24,4)). Veicot post-hoc analīzi, sākotnējā SF-36v2 vidējā vērtība statistiski nozīmīgi atšķīās no SF-36v2 vidējās vērtības pēc $6(p=0,033)$ un 12 mēnešiem $(p=0,043)$. Līdzīgi statistiski nozīmīga atšksirība tika konstatēta MCS pašnovērtējumā $\left(p=0,045, \eta^{2}=0,38\right)$, kur uzsākot pētījumu, šì vērtība bija visaugstākā $(50,1(7,8))$, bet pēc 6 un 12 mēnešiem tā samazinājās, attiecīgi 47,9 (7,3) un 44,5 (7,8). Veicot post-hoc analīzi, statistiski nozīmīga atšķirība bija starp 6 un 12 mēnešiem 
( $p=0,052)$. Pārējo SF-36v2 domēnu vidējās vērtības MT grupā 6 un 12 mēnešu periodā statistiski nozīmīgi neatšķīrās $(p>0,05)$. Visu SF-36v2 domēnu izmaiņas gada laikā atspoguḷotas 3.25.attēlā.

Vidējās SF-36v2 vērtības, kas mazākas par 50 punktiem, saglabājās visā novērošanas periodā GH, PCS un MCS pašnovērtējumā. Sešus un 12 mēnešus pēc iekļaušanas pētījumā samazinājās SF-36v2 vidējās vērtības (kḷuva mazākas par 50 punktiem) PF $(49,3$ (24,5) un 49 (20)), kā arī RP $(34,6(20,4)$ un attiecīgi 37,5 (24,4)) domēnos. Augstākas par 70 punktiem SF-36v2 vidējās vērtības tika novērotas SF domēnā visā novērošanas periodā, bet vidējās vērtības psihiskās veselības (MH) domēnā tomēr pēc 6 un 12 mēnešiem nedaudz samazinājās, taču šīs izmaiņas nebija statistiski nozīmīgi atšķirīgas $(p=0,096)$. Katras vizītes SF-36v2 domēnu vidējās vērtības medikamentozās terapijas grupu pacientiem atspogulotas 8. pielikumā.
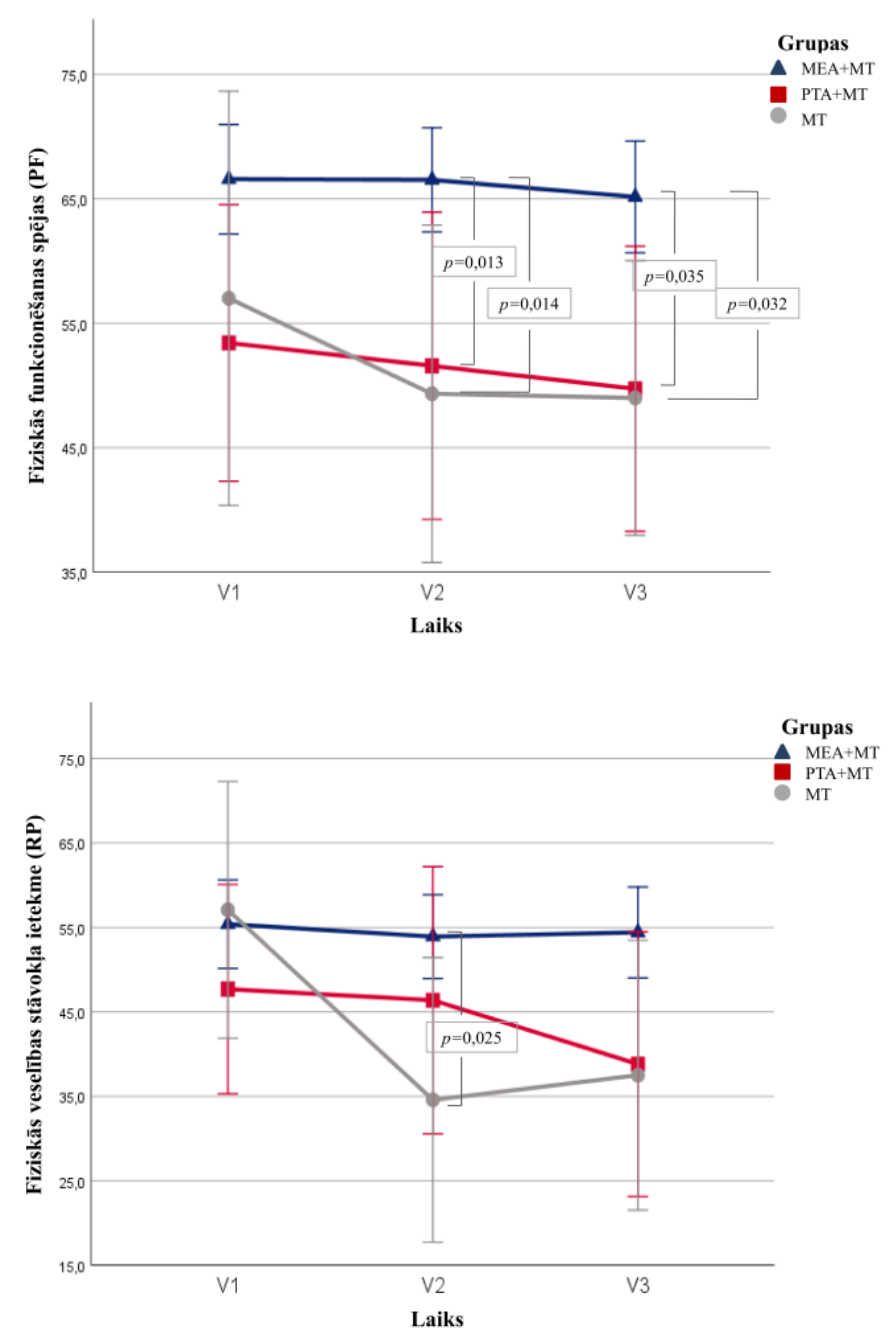

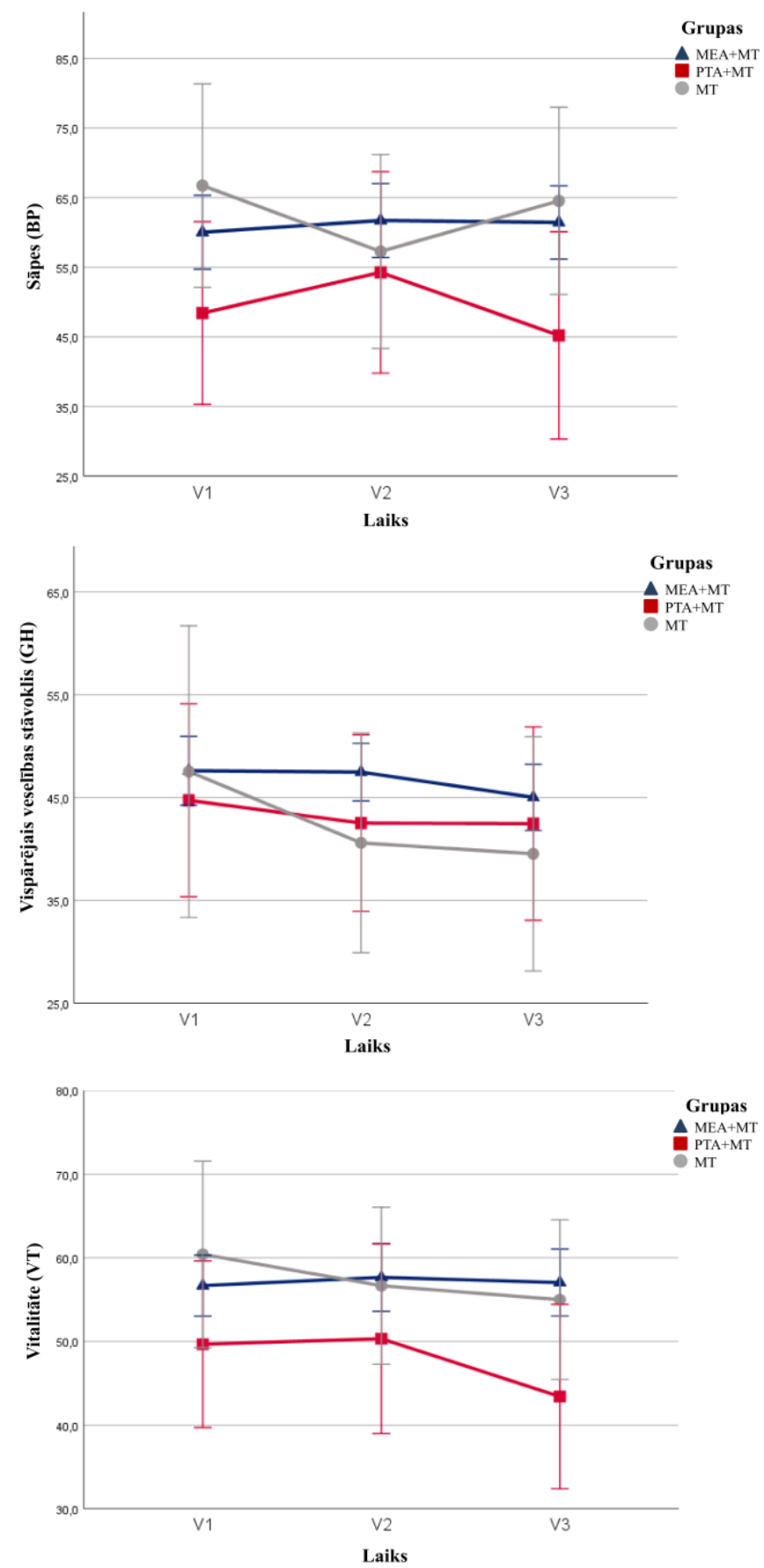

Grupas

$\mathrm{MEA}+\mathrm{MT}$
$\mathrm{PTA}+\mathrm{MT}$

MT

MEA+MT
PTA+MT
MT

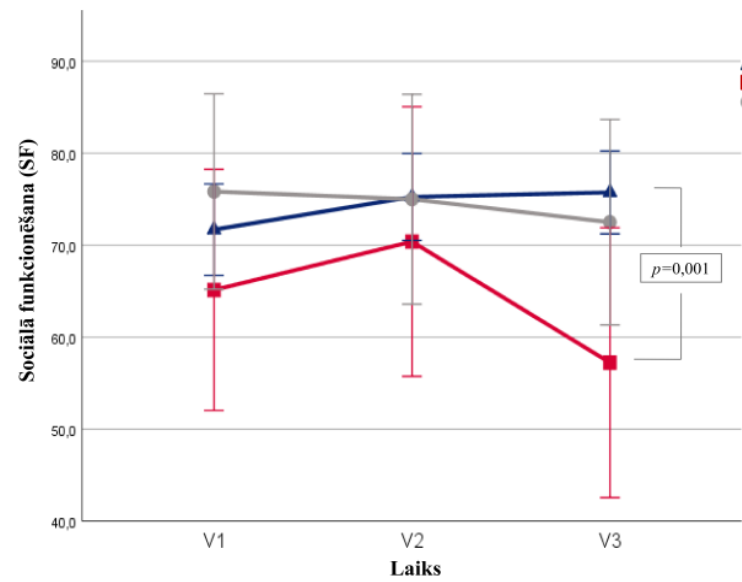

Grupas

. ${ }_{\mathrm{PTA}+\mathrm{MT}}^{\mathrm{MEA}+\mathrm{MT}}$

MT 

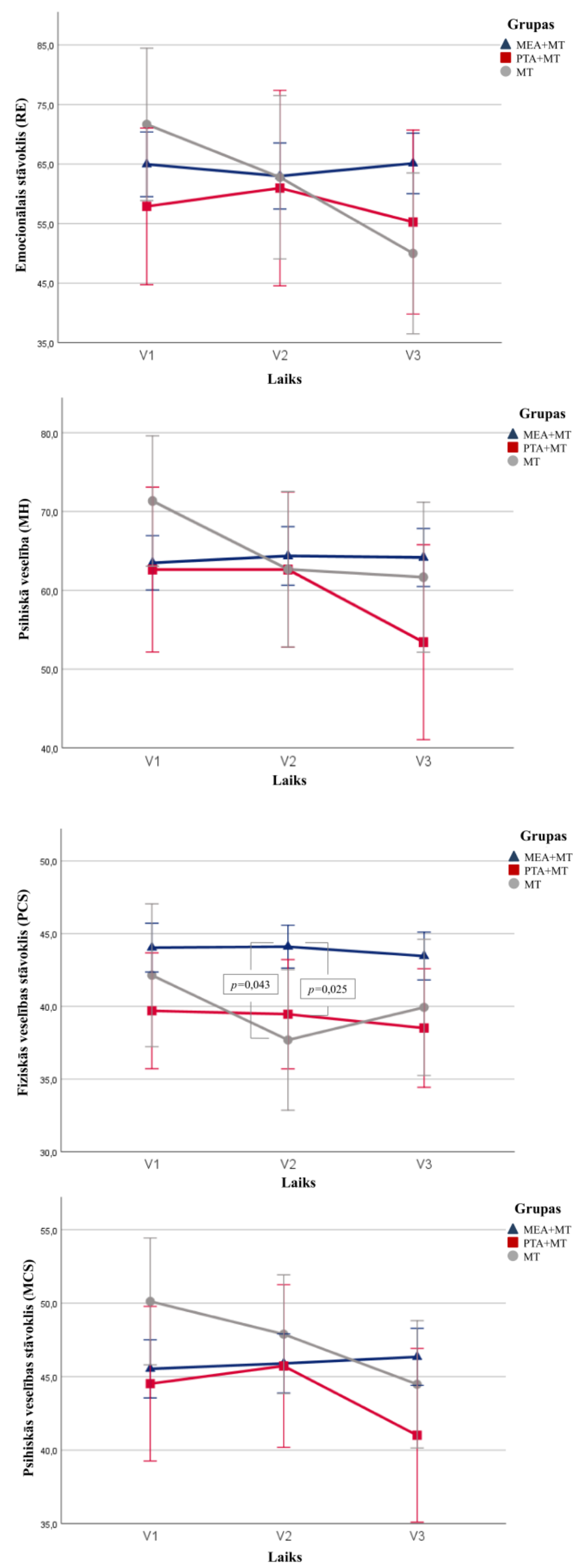

3.25. attēls. SF-36v2 vidējo vērtību izmaiṇas gada laikā pētāmās grupās 


\subsubsection{Dzīves kvalitātes salīdzinājums starp grupām}

Salīdzinot dz̄ives kvalitāti savstarpēji 6 mēnešus pēc iekļaušanas pētījumā, SF-36v2 vidējo vērtību statistiski nozīmīgas atšksirības tika novērotas PF, RP un PCS domēnos. Fiziskās funkcionēšanas vērtējums bija augstāks MEA+MT grupā $(66,5(21,3))$ salīdzinot ar abām pārējām grupām (PTA+MT grupā: 51,6 (25,6); MT grupā: 49,3 (24,5)), ( $p=$ = 0,001, $\left.\eta^{2}=0,076\right)$. Veicot post-hoc analīzi, statistiski nozīmīga atšķirība bija starp MEA+MT un PTA+MT grupu ( $p=0,013)$, kā arī starp MEA+MT um MT grupu ( $p=0,014)$. Domēna RP vērtējums augstāks bija MEA+MT grupā $(53,9$ (25,2)) nekā abās pārējās grupās: PTA+MT $(46,4(32,8))$ un MT $(34,6(20,4))$. Lai gan šīs atšķirības bija statistiski nozīmīgas $(p=0,012)$, tomēr statistiskā efekta lielums bija mazs $\left(\eta^{2}=0,05\right)$. Salīdzinot PCS domēna vērtējumus katrā grupā, augstākā vidējā vērtība bija MEA+MT grupā $(44,1(7,5))$, kas statistiski nozīmīgi ( $\left.p=0,005, \eta^{2}=0,061\right)$ atšķīrās no abu pārējo grupu vidējām vērtībām: PTA+MT: $(39,5(7,8))$ un MT: $(37,7(8,7))$. Pārējo SF-36v2 domēnu vidējās vērtības 6 mēnešos starp grupām statistiski nozīmīgi neatšḳīrās $(p>0,05)$. SF-36v2 vidējo vērtību izmaiņas starp grupām 6 mēnešu laikā atspoguļotas 3.25. attēlā. un 9. pielikumā.

Salīdzinot SF-36v2 vidējo vērtību atšķirības visās grupās 12 mēnešus pēc iekḷaušanas pētījumā, statistiski nozīmīgas atšķirības $(p<0,05)$ tika novērotas sekojošos domēnos: PF, RP, VT, SF, RE, MH un MCS, tomēr SF-36v2 vidējo vērtību statistiskā efekta lielums bija vidējs tikai PF un SF domēnos. Fiziskās funkcionēšanas (PF) vērtējums bija augstāks MEA+MT grupā $(65,1(22,8))$, kas statistiski nozīmīgi $\left(p=0,004 ; \eta^{2}=0,065\right)$ atšḳīrās no abu pārējo grupu vidējām vērtībām: PTA+MT: 49 (23,8) un MT: 49 (20). Līdzīgi SF novērtējuma SF-36v2 vidējās vērtības bija augstākas MEA+MT grupā $(75,7(22,9))$ nekā abās pārējās grupās: PTA+MT: 57,2 (30,4) un MT: 72,5 (20,2), $p=0,002, \eta^{2}=0,072$. Veicot post-hoc analīzi statistiski nozīmīga atšksirība bija tikai starp MEA+MT un PTA+MT grupu ( $p=0,001)$. Lai gan pārējos SF-36v2 domēnos vidējās vērtības statistiski nozīmīgi atškšīās, tomēr šo atšķirīibu statistiskais efekts bija mazs: RP $\left(p=0,016 ; \eta^{2}=0,049\right)$, VT $(p=0,014$; $\left.\eta^{2}=0,051\right), \operatorname{RE}\left(p=0,017 ; \eta^{2}=0,049\right), \operatorname{MH}\left(p=0,03 ; \eta^{2}=0,042\right)$ un $\operatorname{MCS}(p=0,03$; $\left.\eta^{2}=0,049\right)$. SF-36v2 vidējo vērtību izmaiṇas starp grupām 12 mēnešu laikā atspoguḷotas 3.25. attēlā. un 10. pielikumā. 


\subsubsection{Dzīves kvalitātes izmaiṇu saistība ar klīniskiem raksturlielumiem}

\subsubsection{Dz̄̄̄es kvalitātes izmaiņu saistība ar klīniskiem raksturlielumiem MEA+MT grupā}

Analizējot SF-36v2 domēnu vidējo vērtību starpības jeb dzīves kvalitātes izmaiṇas laikā saistību ar vecumu, statistiski nozīmīga korelācija netika novērota.

Salīdzinot SF-36v2 domēnu vidējo vērtību starpību rādītājus starp dzimumiem, kā arī starp to, vai pacientam ir vienpusēja vai bilaterāla miega artērijas stenoze un vai dzīves kvalitātes izmaiņas laikā bija atšķirīgas ar vai bez simptomātiskas miega artērijas, statistiski nozīmīgas atšķirības tomēr netika konstatētas $(p>0,05)$.

Analizējot SF-36v2 domēnu vidējo vērtību starpību rezultātus atkarībā no tā, vai pacients slimoja ar KSS, AH, HSM, MA vai CD, statistiski nozīmīgas atšķirības netika konstatētas $(p>0,05)$. Savukārt nosakot SF-36v2 domēnu vidējo vērtību starpības atšķirības atkarībā no PAS sastopamības, konstatēja, ka vidējās vērtības BP domēnā pasliktinājās pacientiem ar PAS $(p=0,036)$, tomēr statistiskā efekta lielums bija mazs $(r=0,188)$. Analizējot, vai vidējo vērtību starpību atškirība bija atkarīga no smēķēšanas, novēroja, ka nesmēķētājiem sāpju domēnā ir vērojama pozitīva starpība, savukārt smēķētājiem - negatīva, tas ir, pēc gada smēķētāju grupā sāpes bija izteiktākas nekā smēķētāju grupā ( $p=0,006$; $r=0,25)$. Savukārt nosakot saistību starp blakusslimību skaitu un SF-36v2 vidējo vērtību izmain̄ām gada laikā, novēroja statistiski nozīmīgu negatīvu vāju korelāciju starp blakusslimību skaitu un fiziskās funkcionēšanas spējām $\left(\mathrm{r}_{\mathrm{s}}=-0,199, p=0,027\right)$.

Statistiski nozīmīgas atšksirības SF-36v2 domēnu starpību vērtībās netika novērotas ne atkarībā no tā, vai pacientam bija restenoze, ne arī, vai bija lokālas komplikācijas, kas saglabājās gadu pēc operācijas $(p>0,05)$.

Nosakot SF-36v2 vidējo vērtību starpības korelāciju ar kopējās kognitīvās funkcijas relatīvās izteiktības vērtību jeb izmaiņām gada laikā, statistiski nozīmīga korelācija netika atrasta $(p>0,05)$. Kā arī salīdzinot SF-36v2 vidējo vērtību starpību atkarībā no tā, vai pacientam bija depresijas simptomi pirms revaskularizācijas, statistiski nozīmīgas atškirīibas starp vidējām vērtībām netika novērotas $(p>0,05)$.

Apkopojot iepriekšminēto, AVSDzK domēnu vidējo vērtību izmaiņas gada laikā MEA+MT grupā bija saistītas ar lielāku blakusslimību skaitu, kur līdz ar pieaugošu blakus slimību skaitu kḷuva izteiktāki visa veida fizisko aktivitāšu ierobežojumi. Turklāt tika novērots, ka smēķētājiem sāpes kḷuva izteiktākas nekā nesmēķētājiem. 


\subsubsection{Dz̄̄ves kvalitātes izmainu saistība ar klīniskiem raksturlielumiem PTA+MT grupā}

Analizējot SF-36v2 domēnu vidējo vērtību starpības jeb dzīves kvalitātes izmaiṇas laikā saistību ar vecumu, statistiski nozīmīga korelācija netika novērota.

Salīdzinot SF-36v2 domēnu vidējo vērtību starpību rādītājus starp dzimumiem, kā arī starp to, vai pacientam ir vienpusēja vai bilaterāla miega artērijas stenoze un vai dzīves kvalitātes izmaiņas laikā bija atšksirīgas ar simptomātisku miega artēriju, statistiski nozīmīgas atšksirības netika konstatētas $(p>0,05)$.

Analizējot SF-36v2 domēnu vidējo vērtību starpību rezultātus atkarībā no tā, vai pacients slimo ar AH, HSM, MA, PAS un vai pacients ir smēķētājs, statistiski nozīmīgas atšķirības netika konstatētas $(p>0,05)$. Savukārt nosakot vidējo vērtību starpības atškirīības atkarībā no tā, vai pacients slimo ar KSS, konstatēja, ka PF domēnā bija negatīva vidējo vērtību starpība KSS grupā ( $p=0,016 ; r=0,5)$. Līdzīgi CD pacientiem, RP domēnā novēroja negatīvu starpību - vidējās vērtības V3 laikā bijušas mazākas nekā V1 laikā. Minētās atšķirības bija statistiski nozīmīgas $(p=0,011, r=0,5)$. Analizējot saistību starp SF-36v2 domēnu vidējo vērtību starpību rezultātiem un blakusslimībuskaitu, statistiski nozīmīga asociācija netika novērota $(p>0,05)$.

Salīdzinot SF-36v2 vidējo vērtību starpības rezultātus atkarībā no tā, vai pacientam bija restenoze, kā arī, vai bija lokālas komplikācijas, kas saglabājās gadu pēc operācijas, tad statistiski nozīmīgas atsķirības netika novērotas $(p>0,05)$.

Nosakot SF-36v2 vidējo vērtību starpības saistību arMoCA testa kopējās kognitīvās funkcijas relatīvās izteiktības vērtību jeb izmaiṇām gada laikā, statistiski nozīmīga korelācija netika atrasta $(p>0,05)$. Kā arī, salīdzinot SF-36v2 domēnu vidējo vērtību starpību atkarībā no tā, vai pacientam bija depresijas simptomi pirms revaskularizācijas, statistiski nozīmīgas atšķirības starp vidējām vērtībām netika novērotas $(p>0,05)$.

Apkopojot iepriekšminēto, šajā pētījumā bija novērota saistība starp AVSDzK izmaiṇām un tādām blakus saslimšanām kā KSS un CD. Pacientiem ar KSS novēroja izteiktākus fizisko aktivitāšu ierobežojumus pēc gada, savukārt pacientiem ar CD novēroja izteiktākas grūtības veikt darbu un ikdienas aktivitātes, kas radušās fiziskās veselības problēmu dēl

\subsubsection{Dż̄̄es kvalitātes izmaiņu saistība ar klīniskiem raksturlielumiem MT grupā}

Analizējot SF-36v2 domēnu vidējo vērtību starpības jeb dzīves kvalitātes izmaiņas laikā saistību ar vecumu, statistiski nozīmīga korelācija netika novērota. 
Salīdzinot SF-36v2 domēnu vidējo vērtību starpību rādītājus starp dzimumiem, kā arī starp to, vai pacientam ir vienpusēja vai bilaterāla miega artērijas stenoze un vai dzīves kvalitātes izmaiņas laikā bija atšķirīgas ar vai bez simptomātiskas miega artērijas, statistiski nozīmīgas atšķirības tomēr netika konstatētas $(p>0,05)$.

Analizējot SF-36v2 domēnu vidējo vērtību starpību rezultātus atkarībā no tā, vai pacients slimoja ar KSS, AH, HSM, MA, CD vai PAS, statistiski nozīmīgas atšķirības netika konstatētas $(p>0,05)$. Analizējot, vai vidējo vērtību starpību atšķirība bija atkarīga no smēķēšanas, novēroja, ka nesmēķētājiem sāpju domēnā ir vērojama pozitīva starpība, savukārt smēķētājiem - negatīva, tas ir, pēc gada nesmēķētāju grupā sāpes nebija tik izteiktas kā smēķētāju grupā ( $p=0,05 ; r=0,15)$, taču statistiskā efekta lielums bija mazs. Nosakot saistību starp SF-36v2 domēnu vidējo vērtību starpības izmaiņām un blakusslimību skaitu, tika novērota statistiski nozīmīga negatīva vidēji cieša korelācija $\mathrm{GH}$ domēnā $\left(\mathrm{r}_{\mathrm{s}}=-0,458\right.$, $p=0,048)$.

Salīdzinot SF-36v2 vidējo vērtību starpības rezultātus atkarībā no tā, vai pacientam bija restenoze, kā arī, vai bija lokālas komplikācijas, kas saglabājās gadu pēc operācijas, tad statistiski nozīmīgas atšķirības netika novērotas $(p>0,05)$.

Analizējot SF-36v2 vidējo vērtību starpības saistību ar MoCA testa kopējās kognitīvās funkcijas relatīvās izteiktības vērtību jeb izmaiņām gada laikā, statistiski nozīmīga korelācija netika atrasta $(p>0,05)$. Savukārt nosakot to, vai vērojama SF-36v2 vidējo vērtību starpības atšķirīibas atkarībā no tā, vai pacientam bija depresijas simptomi pirms pētījuma, tad pacientiem, kuriem sākotnēji bija depresijas simptomi, vidējo vērtību starpība SF domēnā bija +15,0 un RE domēnā tā bija + 0,002, norādot, ka gada laikā šiem pacientiem sociālā funkcija un emocionālais stāvoklis bija uzlabojies paša pacienta vērtējumā. Toties pacientiem, kuriem sākotnēji depresijas nebija, gan SF, gan RE domēnā vidējo vērtību starpības bija negatīvas vērtības ( SF: - 8,3 un RE: - 27,78), kas savukārt norāda, ka šiem pacientiem sociālā funkcija un emocionālais stāvoklis bija pasliktinājies. Šo SF-36v2 domēnu starpības bija statistiski nozīmīgi atšķirīgas gan SF ( $p=0,048, r=0,49)$, gan RE $(p=0,037, r=0,5)$ domēnos. 


\section{DISKUSIJA}

Demogrāfiskie un klīniskie raksturlielumi bija līdzịgi bieži sastopami visās grupās, izņemot atsevišķus, bet bez statistiski ticamas atšķirības. Iemesls šīm atšķirībām, kas vienlaicīgi jāuzskata arī par pētījuma ierobežojumu, ir pētījuma raksturs. Proti, šis nebija randomizēts kontrolēts pētījums, bet gan prospektīvs kohortas pētījums, kur lēmumu par nozīmīgas miega artērijas stenozes ārstēšanu saskaņā ar indikācijām pieņēma ārstējošais ārsts un pacients neatkarīgi no pētījuma. Tāpēc iespējamība, ka notikusi selekcijas kḷūda, ir salīdzinoši liela. Datu analīze liecināja, ka MEA+MT grupā vairāk bija asimptomātiskas miega artērijas stenozes pacienti, bet MT grupā vairāk simptomātiski pacienti. Tas varētu norādīt uz to, ka pêtījuma norises vietā biežāk operēja zema ķirurǵiska riska pacientus, nevis simptomātiskus pacientus kā to rekomendē vadlīnijas. Tomēr, jāṇem vērā, ka pētījums norisinājās no 2015. līdz 2017. gadam, kad tā laika vadlīnijas (Tendera et al., 2011) nedaudz atšķīrās no esošajām 2018.gada (Naylor et al., 2018) vadlīnijām. Iepriekšējās vadlīnijās nebija rekomendācijas par tikai medikamentozas ārstēšanas pielietošanu asimptomātiskas miega artērijas stenozes pacientiem, ja išēmiska insulta risks ir zems. Līdzīgi, PTA+MT grupā biežāk bija sastopami KSS pacienti, kas varētu liecināt, ka PTA kā metode tika izvēlēta augstāka ķirurǵiska riska dēḷ. Tomēr jāpiemin, ka PTA tika izvēlēta gan simptomātiskiem ar dažādu ķirurgiisko risku, gan asimptomātiskiem pacientiem, jo pētījuma laikā esošās vadlīnijas nenorādīja MEA pārākumu pār PTA, kā arī tas, ka daudzi pacienti šajā grupā tika iekḷauti no Latvijas kardioloǵijas centra, kur priekšroka tika dota PTA. Ņemot vērā šos faktus, pētījuma galvenais uzdevums bija noteikt kognitīvās funkcijas, depresijas simptomu un dzīves kvalitātes izmaiņas pacientiem, kuriem veica nozīmīgas miega artērijas stenozes revaskularizāciju vai tikai uzsāka optimālu medikamentozo terapiju, bet revaskularizāciju neveica.

Atšķirīiāa no vecākiem pētījumiem, kur kognitīvās funkcijas izmaiņas pēc miega artērijas revaskularizācijas netika apstiprinātas (De Rango et al., 2008), šajā pētījumā kognitīvās funkcijas uzlabošanos novēroja MEA+MT un PTA+MT grupās. Miega artērijas endarterektomijas grupā uzlabošanos konstatēja uzmanības, valodas, vispārināšanas un atmiņas domēnos, savukārt PTA+MT grupā - vizuāli telpiskās uztveres/vadības funkcijas domēnos. Medikamentozajā grupā, atšķirībā no revaskularizētajiem pacientiem, kognitīvās funkcijas uzlabošanās, izvērtējot kopējās MoCA skalas mediānasvērtības, netika novērota.

Kognitīvās funkcijas uzlabošanos varētu skaidrot dažādi. Ir zināms, ka samazināta asins plūsma smadzenēs var izraisīt nozīmīgu kognitīvu disfunkciju (Marshall et al., 2012;Balucani et al., 2012). Vairāki pētījumi rāda, ka nozīmīgas miega artērijas stenoze ir 
asociēta ar sliktāku kognitīvo funkciju (Lal, Dux, et al., 2017; Popovic et al., 2011; Mathiesen et al., 2004; Jackson et al., 2015; Wang, Mei and Zhang, 2016; Pucite et al., 2017) cerebrālu hemodinamisku traucējumu dēl (Silvestrini et al., 2009; Marshall et al., 2012).Veicot endarterektomiju vai stentēšanu, "mehāniski" tiek uzlabota asins plūsma galvas smadzenēs un attiecīgi arī galvas smadzeņu perfūzija. Palielinoties asins plūsmai un perfūzijai pēc miega artērijas revaskularizācijas, uzlabojas gan kopējā kognitīvā funkcija, gan tādi noteikti kognitīvās funkcijas domēni kā vadības funkcija, uzmanība un atmiņa (Ghogawala et al., 2013; Fearn et al., 2003; Kishikawa et al., 2003; Wang et al., 2017; Huang et al., 2013).

Šajā pētījumā kognitīvā funkcija gada laikā uzlabojās pacientiem pēc revaskularizācijas, taču pacientiem medikamentozajā grupā kognitīvās funkcijas būtiska uzlabošanās, salīdzinot kopējās MoCA skalas mediānas vērtības pētījuma sākumā un beigās, netika novērota, tā palika nemain̄̄ga. Lai teorētiski varētu salīdzināt kognitīvās funkcijas uzlabošanās lielumu jeb pakāpi starp pētāmām grupām, tika aprēķinātas MoCA testa kopējās kognitīvās funkcijas relatīvās izteiktības mediānas vērtības katrā pētāmā grupā. Salīdzinot šīs vērtības savā starpā, novēroja, ka nebija statistiski nozīmīgas atšķirības starp visām 3 pētāmām grupām. Tas varētu liecināt, ka kognitīvas funkcijas izmaiṇas ir saistītas ne tikai ar mehānisku miega artērijas revaskularizāciju, bet arī ar pielietoto agresīvo moderno medikamentozo terapiju, kas ne tikai uzlabo, bet arī saglabā kognitīvās funkcijas līmeni asimptomātiskas nozīmīgas miega artērijas stenozes pacientiem (Lin et al., 2016). Savukārt, simptomātiskas miega artērijas stenozes pacientiem medikamentozā terapija samazina atkārtota išēmiska notikuma risku un attiecīgi vaskulāru kognitīvu deficītu. Turklāt ārstējot tādus vaskulāros riska faktorus kā arteriāla hipertensija, hiperholesterinēmija, cukura diabēts, smēķēěana, kas var veicināt galvas smadzeņu sīko asinsvadu bojājumu, tiek samazināts gan galvas smadzeņu baltās vielas bojājums (Prins and Scheltens, 2015), gan arī lakunāru infarktu risks distālas aterosklerozes dēl (Pantoni, 2010), kas novērš kognitīvu traucējumu progresēšanu (Shi and Wardlaw, 2016). Tāpēc medikamentozā terapija kombinācijā ar ķirurǵisku vai endovaskulāru ārstēšanu varētu ietekmēt pacienta kognitīvo funkciju.

Pastāv vēl arī cits iespējamais izskaidrojums, kāpēc pacientiem pēc miega artērijas stenozes ārstēšanas uzlabojas kognitīvā funkcija. Tas potenciāli varētu būt saistîts ar MoCA testa iemācīšanās efektu, tas ir, atkārtoti veicot vienu un to pašus uzdevumus, pacienti varētu uzlabot MoCA testa izpildes rezultātus. Šajā pētījumā MoCA testa rezultātu uzlabošanās nevarētu būt saistīta tikai un vien̄̄gi ar iemācīšanās efektu, jo kognitīvās funkcijas uzlabošanās netika novērota MT grupā, kur arī šie pacienti kā visi pārējie veica vienu un to pašu testu pēc 6 un 12 mēnešiem. Tomēr jāṇem vērā, ka MT grupā bija vairāk pacienti ar simptomātisku miega artērijas stenozi. Tang et al. sistēmiskajā literatūras apskatā un 
metaanalīzē secina, ka insults ir saistîts ar palielinātu risku kognitīviem traucējumiem, bet kognitīvi traucējumi var nebūt tieši insulta sekas. Faktori, kas asociēti ar kognitīvās funkcijas pasliktināšanos pēc cerebrovaskulāra notikuma, ir sociodemogrāfiskais stāvoklis, blakussaslimšanas, iepriekš jau pārciesti CI un neiroloǵiskais defekts (Tang et al., 2018). Tāpēc arī šie faktori varēja ietekmēt to, ka MT grupā kognitīvas funkcijas dinamiku pārliecinoši nevēroja gada laikā. Ir bijuši tikai daži pētījumi, kas novērtējuši MoCA testa izmaiņas veseliem, gados vecākiem cilvēkiem, bet ne pacientiem ar nozīmīgu miega artērijas stenozi vai pārciestu insultu kādā laika posmā. Šo pētījumu dati rāda, ka MoCA testa rezultātu uzlabošanās ir saistīta ar iemācīšanās efektu veseliem cilvēkiem, ja to atkārtoti veica gada laikā, bet iemācīšanās efektu nenovēroja, ja otro reizi MoCA tests tika atkārtots vairāk kā pēc viena gada (Cooley et al., 2015; Krishnan et al., 2016). Vai šo novērojumu varētu attiecināt uz pacientiem, kuriem ir nozīmīga asimptomātiska vai simptomātiska miega artērijas stenoze, nav zināms. Interesanti, ka Cooley et al. veiktajā pētījumā tika novērota saistība starp iemācīšanās efektu un MoCA testa atkārtotu veikšanu gada laikā, bet šāds iemācīšanās efekts netika pierādīts ar neiropsiholog̣iskiem testiem tādā pašā laika periodā, jo visiem pacientiem bez MoCA testa veica arī neiropsiholoǵisko testēšanu (Cooley et al., 2015). Šo novērojumu, savukārt, apstrīd Plessers et al.veiktais pētījums, kur novēroja iemācīšanās efektu pacientiem, kuriem veica neiropsiholoǵisko testēšanu (Plessers et al., 2015). Plessers et al. pētījumā kognitīvus traucējumus sākotnēji novēroja pētāmajā un kontroles grupā. Kontroles grupā bija pacienti ar perifēro artēriju slimību, kuriem bija līdzīgi riska faktori kā pētāmajai grupai ar nozīmīgu miega artērijas stenozi - cukura diabēts, arteriāla hipertensija, hiperholesterinēmija un smēķēšana. Pēc šī pētījuma tika secināts, ka veicot atkārtoti vienus un tos pašus testus, kognitīvās funkcijas uzlabošanās ir saistāma ar iemācīšanās efektu. Tomēr š̄ pētījuma rezultātus var uzskatīt par neviennozīmīgiem, jo nav pierādīts, ka kognitīvās funkcijas uzlabošanās pacientiem gan pētāmā grupā, kuriem veica miega artērijas revaskularizāciju, gan kontroles grupā, bija saistāma ar iemācīšanās efektu vai tomēr ar to, ka šie pacienti saṇēma kardiovaskulāro riska faktoru korig̣ējošu ārstēšanu ciešā ārsta uzraudzībā, kas kā zināms samazina kognitīvo traucējumu vai demences attīstību (Baumgart et al., 2015). Mūsu pētījums tika uzsākts pirms literatūrā bija pieejamainformācija par MoCA testa iemācǐšanās iespējamo efektu. Tāpēc šis būtu vēl viens aspekts, kas būtu jāpierāda tupmākos pētījumos, jo literatūrā nav informācijas par MoCA testa iemācīšanās efektu pacientiem ar cerebrovaskulāriem notikumiem vai miega artērijas stenozi.

Analizējot MoCA testa domēnus, novēroja nelielu atšķirību starp grupām. MEA+MT grupā kognitīvās funkcijas uzlabošanos novēroja vairākos domēnos: uzmanība, valoda, vispārināšana un atmiņa $(p<0,04)$. PTA+MT grupā uzlabošanās tika novērota tikai vizuāli 
tepliskās uztveres/vadības funkcijas domēnā $(p=0,01)$, savukārt medikamentozā grupā - atmiņas domēnā. Tomēr jāatzīmēe, ka neskatoties uz statistiski nozīmīgām izmaiņām katrā grupā pētāmā perioda laikā, statistiskā efekta lielums bija mazs, tāpēc šie dati ir jāvērtē piesardzīgi. Teorētiski MoCA testa domēnu izmaiņām abās revaskularizācijas grupās jābūt līdzīgām, tomēr šajā pētījumā tas netika novērots. Izskaidrojums šīm atšķirībām varētu būt dažāds. Pirmkārt, dažus kognitīvās funkcijas domēnus MoCA tests pārbauda ar vairākiem uzdevumiem. Piemēram, atņemšana, kas ietilpst uzmanības domēnā MoCA testā, un vārdu nosaukšana minūtes laikā, kas ir iekḷauta valodas domēnā, arī ir dạ̧a no vadības funkcijas pārbaudes (Nasreddine et al., 2005). Tāpēc varētu domāt, ka bez uzmanības, valodas un atmiņas, daļēji arī vadības funkcija uzlabojas MEA+MT grupā. Taču jāņem vērā, ka statistiskā efekta lielums ir mazs, tāpēc rezultāti iespējams mainītos, ja pētāmās populācijas būtu skaitliski lielākas. Otrs izskaidrojums MoCA domēnu atšķirīgiem rādītājiem starp reperfūzijas grupām varētu būt tāds, ka neskatoties uz protekcijas ierīcēm, mikroemboli miega artērijas stentēšanas laikā var izraisīt klīniski nemanāmus infarktus (Cosottini et al., 2005; Chen et al., 2006; Maleux et al., 2006). Tāpat arī, transitīva hipoperfūzija PTA laikā var īslaicīgi pasliktināt galvas smadzeņu perfūziju, īpaši ja ir bilaterāla tandēma stenoze vai difūza intrakraniāla artēriju slimība. Tāpēc iespējams kognitīvās funkcijas uzlabojums no atjaunotāsasins plūsmas smadzenēs pēc PTA paliek apslēpts vai izlīdzināts minēto PTA negatīvo efektu dēḷ (Huang et al., 2013). Papildus iepriekš teiktajam, jāatceras, ka MoCA tests kā skrīninga instruments vaskulāriem kognitīviem traucējumiem nav tik sensitīvs kāa standartizēti neiropsihologiiskie testi, kas varētu precīzāk pierādīit smalkākas izmaiņas konitīvās funkcijas domēnos.

Literatūrā maz ir sastopami pētījumi, kas novērtētu un salīdzinātu ilgtermiṇa kognitīvās funkcijas dinamiku jeb izmaiņas pēc revaskularizācijas (MEA un PTA) un MT. Tie pētījumi, kas to ir veikuši, izmantoja atšķirīgu metodologijiju, tāpēc precīza šo pētījumu apkopošana un salīdzināšana ir apgrūtināta. Taču neskatoties uz to, šo pētījumu izdarītie secinājumi ir līdzīgi. Watanabe et al. pētījumā izmantoja MoCA testu un novēroja, ka gada laikā kopējais MoCA punktu skaits palielinās tikai pēc revaskularizācijas (MEA, PTA), bet ne MT grupā. Šie rezultāti sakrīt ar mūsu pētījuma rezultātiem. Watanabe et al. pētījumā tika novērota uzlabošanās vadības un atmiņas domēnos miega artērijas endarterektomijas grupā, atmiņas domēnā medikamentozās terapijas grupā, bet endovaskulārās revaskularizācijas grupā MoCA atsevišķu domēnu uzlabošanās netika novērota (Watanabe et al., 2017), kas dal̦ēji ir līdzīgi ar mūsu pētījuma rezultātiem. Uzlabošanās tieši šajos iepriekš minētajos domēnos varētu būt izskaidrojama ar to, ka samazināta perfūzija priekšējā cirkulācijas baseinā ir saistīta ar sliktāku vadības un atmiņas funkciju (Alosco et al., 2013). Savukārt galvas smadzeņu asins 
plūsmas uzlabošanās a. cerebri media, ko vēro pēc miega artērijas revaskularizācijas, ir saistīta ar vadības, uzmanības (Ghogawala et al., 2013) un atmiņas funkcijas uzlabošanos (Wang et al., 2017). Pētījumu, kas pētīja MoCA testa izmaiņas gada laikā atsevišķi vai nu pēc miega artērijas endarterektomijasvai endovaskulāras revaskularizācijas salīdzinājumā ar kontroles grupu, galvenais secinājums bija apgalvojums, ka miega artērijas revaskularizācija varētu uzlabot vai nodrošināt kognitīvo funkciju iepriekšèjā līmenī gan simptomātiskiem, gan asimptomātiskiem gados vecākiem nozīmīgas miega artērijas stenozes pacientiem (Baracchini et al., 2012; Yan et al., 2014).

Pētījumu rezultāti, kas novērtējuši nozīmīgas miega artērijas stenozes ārstēšanas metodes (MEA, PTA vai MT) ietekmi uz kognitīvo funkciju ilgtermin̄ā, ir līdzīgi, tas ir, nozīmīgas miega artērijas stenozes revaskularizācija uzlabo ilgtermiņa kognitīvo funkciju neatkarīgi no ārstēšanas veida (Wapp et al., 2015; Carta et al., 2015; Dempsey, Jackson, et al., 2017; Kim et al., 2015; Kougias et al., 2015). Tomēr literatūrā ir arī pieejami pētījumi, kas nenovēro kognitīvās funkcijas izmaiņas pēc miega artērijas revaskularizācijas (MEA, PTA) (Aleksic et al., 2006; Altinbas et al., 2011). Šo agrīno pētījumu rezultātus nepieciešams izvērtēt piesardz̄̄gi, jo pēdējo desmit gadu laikā ne tikai cerebrovaskulāro slimību farmakoloǵiskā terapija ir ievērojami uzlabojusies, bet arī miega artērijas revaskularizācijā pielietotās tehnoloǵijas un ārstu tehniskās iemaņas, kas varētu mainīt rezultātus, ja šos pētījumus atkārtotu mūsdienās (Wapp et al., 2015).

Izvērtējot, kuram no pacientiem ir lielāks ieguvums pēc nozīmīgas miega artērijas stenozes ārstēšanas, secinam, ka ievērojamāku kognitīvās funkcijas uzlabošanos pēc 6 un 12 mēnešiem novēroja pacientiem ar zemākām kopējām MoCA vērtībām MEA un MT grupāspētījuma sākumā. PTA grupā ar̄i tika novērota negatīva korelācija starp kognitīvās funkcijas novērtējumu, uzsākot pētījumu, un kopējās kognitīvās funkcijas relatīvās izteiktības mediānas vērtībām pēc 6 un 12 mēnešiem, tomēr š̄ saistība nebija statistiski ticama. Lai gan literatūrā pieejami pretrunīgi dati, mūsu pētījuma rezultāti ir līdzīgi lielākai daḷai citu pētījumu datiem, kur pacienti ar sliktāku kogitīvo funkciju pirms miega artērijas stenozes ārstēšanas, īpaši pacienti ar simptomātisku miega artērijas stenozi, uzrādīja labākus kognitīvās funkcijas pārbaudes testa rezultātus neatkarīgi no ārstēšanas veida. Šos rezultātus pašlaik nav viegli izskaidrot, tomēr uzskata, ka kognitīvās funkcijas uzlabošanās pacientiem ar sliktāku sākotnējo kognitīvo funkciju varētu būt saistīta ar vaskulāro riska faktoru korekciju un perfūzijas uzlabošanu. Otrkārt, kognitīiās funkcijas izmaiņas atspoguḷo dabīgu atveseḷošanās procesu, pateicoties galvas smadzeņu funkcionālās plasticitātes iespējām, īpaši simptomātiskiem pacientiem. Tāpēc var domāt, ka kognitīvās funkcijas uzlabošanās tieši šai pacientu grupai ir saistīta ar visu iepriekšminēto faktoru ietekmi kopā (Baracchini et al., 2012; 
Wapp et al., 2015).Taču ir arī pētījumi, kuru rezultāti rāda pretējo, tas ir, labāka kognitīvā funkcija, uzsākot pētījumu, bija saistīta ar ievērojamāku kognitīvās funkcijas uzlabošanos pēc miega artērijas ārstēšanas (Dempsey, Jackson, et al., 2017). Tāpēc ņemot to visu vērā, ir nepieciešami turpmāki pētījumi, kas apstiprinātu vai noraidītu š̄̄ pētījuma laikā radušos jautājumus un hipotēzes.

Pagājušā gadsimta deviņdesmito gadu beigās Alexopoulus et al. izvirzīja hipotēzi par „vaskulāru depresiju”. Vaskulāra depresija tika definēta kā depresija, kas parādās pacientam ar kādu vaskulāru saslimšanu un/vai vaskulāriem riska faktoriem, kā arī pacientiem arišēmiskām izmaiṇām galvas smadzeņu prefrontālajos rajonos. Prefrontālie rajoni kontrolē cilvēka uzvedību, tāpēc bojājums tajos varētu izskaidrot depresijas simptomu attīstību (Alexopoulos et al., 1997). Nesen tika pārskatîta vaskulāras depresijas hipotēze un apstiprināts, ka vaskulāra depresija varētu būt atseviškss vēlīnas depresijas apakštips, ko raksturo specifiska klīniskā aina, asociācija ar vaskulāriem riska faktoriem un išēmiskām izmain̄ām galvas smadzenēs, kas ir redzamas MR. Iespējamie mehānismi, kuru gadījumā vaskulāras saslimšanas varētu ietekmēt depresijas attīstību un virzību, varētu būt hronisks iekaisums, mehānisks dažādu neironu tīklu, savienojumu bojājums un hipoperfūzija (Aizenstein et al., 2016). Tāpēc šajā pētījumā tika pārbaudīta saistība starp depresiju un nozīmīgu miega artērijas stenozi.

Vispārzināms ir fakts, ka ateroskleroze ir iekaisīga slimība (Ross, 1999), un arvien vairāk ir pierādījumu tam, ka tā piedalās hroniska neiroiekaisuma uzturēšanā organismā. Ilgstošs un lēni noritošs neiroiekaisums var veicināt galvas smadzeņu sīko asinsvadu bojājumu, kā arī līdzdarboties un veicināt vairāku pēcinsulta komplikāciju (demences, depresijas un neirodeǵenerācijas) attīstību. (Sandu et al., 2015). Līdzīgi kā pacientiem ar kardiovaskulārām slimībām un depresiju nav iespējams pierādīt savstarpējo kauzalitāti, tad literatūrā arī pastāv dažādi viedokḷli par depresijas un miega artērijas aterosklerozes saistību un cēlonssakarību. Daži pētījumi apgalvo, ka starp depresiju un miega artērijas aterosklerozi nav savstarpēji nekādas saistības (Rice et al., 2009). Taču ir citi pētījumi, kas to noliedz. Gan šķērsgriezuma (Beutel et al., 2014), gan kohortas (Faramawi et al., 2007; Salaycik et al., 2007) tipa pētījumos pacientiem ar depresiju biežāk novēroja miega artērijas aterosklerozes attīstību. Kā arī ortrādi, gan šķērsgriezuma pētījumos novēroja aterosklerozes un depresijas sasvstarpējo saistību vecākiem cilvēkiem (Tiemeier et al., 2004), gan ilgtermiņa kohorta tipa pētījumos tika norādīts, ka miega artērijas ateroskleroze kā vaskulāra komponente varētu būt tieši iesaistīta depresijas patoǵenēzē veciem cilvēkiem (Seldenrijk et al., 2011; Prugger et al., 2015). 
Lielākai daļai pacientu ar nozīmīgu miega artērijas stenozi ir vairāki kardiovaskulāri riska faktori (arteriāla hipertensija, dislipidēmija, cukura diabēts un citas vaskulāras saslimšanas), kas var izraisīt galvas smadzeņu baltās vielas bojājumu. Ja aterosklerozes vai citu kardiovaskulāru riska faktoru dēḷ sīkie asinsvadi galvas smadzenēs ir bojāti, tie nespēj piedalīties galvas smadzeņu asinsvadu autoregulācijāa, tas ir, tie nespēj maksimāli dilatēties nepieciešamības gadījumā, lai nodrošinātu adekvātu cerebrālu asins plūsmu (Gupta et al., 2012). Tāpēc pacientiem ar nozīmīgu miega artērijas stenozi un traucētu cerebrovaskulārās rezerves funkciju, galvas smadzeņu asins perfūzija ir samazināta vēl izteiktāk nekā pacientiem bez miega artērijas stenozes. Teorētiski, ja veiktu nozīmīgas miega artērijas revaskularizāciju, palielinot cerebrālo perfūzijas spiedienu, tad viens no riska faktoriem baltās vielas bojājumam būtu reducēts, tādējādi aizkavējot depresijas attīstību.

Pretēji Mlekusch et al. veiktajam pētījumam, kur depresijas simptomi mazinājās pēc miega artērijas stenozes stentēšanas (Mlekuschet al., 2006), šajā pētījumā nozīmīgas izmaiņas depresijas simptomu biežumā netika novērotas ne tikai MT grupā, bet arī abās miega artērijas revaskularizācijas grupās ne pēc 6, ne arī pēc 12 mēnešiem. Tāpēc šis pētījums neapstiprina saistību starp galvas smadzeņu hipoperfūziju un depresijas simptomiem nozīmīgas miega artērijas stenozes dēḷ, kā arī to, ka revaskularizācijai varētu būt labvēlīga ietekme uz depresijas simptomu attīstību. Turklāt ir vēl citi pētījumi, kas ir analizējuši depresijas simptomu sastopamību pacientiem ar nozīmīgu miega artērijas stenozi. Protams, ir ļoti apgrūtinoši veikt šo visu pētījumu salīdzinājumu, jo šajos pētījumos ir pielietotas dažādas depresijas simptomu noteikšanas skalas kā Beck Depression and Anxiety scale (Kim et al., 2016), Hamilton depression rating scale (Carta et al., 2015; Aleksic et al., 2006), Geriatric depression scale (Feliziani et al., 2010), Hospital anxiety and depression scale (Wapp et al., 2015), tomēr secinājumi ir līdzīgi - nav nozīmīgu izmaiṇu noskaņojuma un depresijas simptomu attīstībā pēc miega artērijas revaskularizācijas ilgtermiņā, kā arī nav atškirības starp MEA un PTA grupām. Lai gan š̄i pētījuma dizains neļauj salīdzināt pielietoto revaskularizācijas metožu ietekmi uz depresijas simptomu attīstību, tomēr tika novērots, ka depresijas simptomi mazinājās MEA+MT grupā vairāk nekā pēc PTA vai medikamentozās ārstēšanas. Iespējamie izskaidrojumi ir vairāki. Viens no iemesliem varētu būt mazais pacientu skaits PTA+MT un MT grupās. Otrs, lai gan depresijas simptomu biežums pētījuma sākumā bija līdzīgs, taču pacienti pēc MEA iespējams vairāk izjuta atvieglojumu nekā pacienti PTA+MT vai MT grupās. Tas varētu būt saistīts ar "pārdomu/prātuḷošanas" (rumination) un "katastrofālo domāšanu" (catastrophic thinking), tas ir, pacienti pēc operācijas iespējams izjuta atvieglojuma sajūtu un cerību, ka pārciestā sarežǵîtā operācija uzlabos viṇu veselības stāvokli (Sansone \& Sansone, 2012). Līdzīgi rezultāti ir vērojami 
pacientiem pēc sirds operācijas, kur trešdaļai pacientu ar depresīviem simptomiem pirms operācijas, tos vairs nenovēroja pēc operācijas. To skaidroja ar to, ka pirms operācijas nav zināms iznākums, tāpēc pacienti jūtas nedroši ar nomāktu garastāvokli. Taču piedzīvojot veiksmīgu operāciju, šî "pārdomas/prātuḷošana" un "katastrofālā domāšana" izzūd (Horne et al., 2013). Iespējamais izskaidrojums, kāpēc nenovēroja depresijas simptomu biežuma samazināšanos PTA+MT grupā, varētu būt saistīts ar lielāku kardiovaskulāro pacientu skaitu. Ir zināms, ka koronāra sirds slimība ir asociēta ar palielinātu depresijas sastopamību, kur depresijas simptomi saglabājas ne tikai pēc akūtā notikuma, bet arī ilgstoši pēc tā (Huffman et al., 2013). Mūsdienu medikamentozā ārstēšana samazina sīko artēriju bojājumu, tādējādi mazinot arī strukturālu galvas smadzeņu baltās vielas bojājumu (Behrouz, Malek \& Torbey, 2012), kas ir viens no vaskulāras depresijas kritērijiem. Tomēr MT grupā depresijas simptomu attīstības dinamiku nenovēroja. Izskaidrojums varētu būt iepriekš minētā hipotēze par hipoperfūziju kā iemeslu, kas veicina depresijas attīstību. Otrs, pacienti iespējams nav pārliecināti vai tomēr šaubās par savu miega artērijas stenozes ārstēšanas izvēli, tas ir, saglabājas "pārdomas/prātuḷošana" un/vai "katastrofālā domāšana".

Ja pieņem, ka mehānisms, kā attīstās kognitīvi traucējumi pacientiem ar nozīmīgu miega artērijas stenozi, varētu būt līdzīgs depresijas simptomu attīstībā, tad abiem šiem simptomiem būtu jāmazinās pēc revaskularizācijas. Tā kā šajā pētījumā tika novērots, ka kognitīvi traucējumi varētu būt atgriezeniski pēc miega artērijas revaskularizācijas, bet depresijas simptomi nē, tad, mūsuprāt, depresijas simptomi varētu būt kā klīnisks marķieris vēl izteiktākam galvas smadzeņu strukturālam bojājumam vai disfunkcijai, kad šīs izmaiņas jau vairs nav atgriezeniskas. Šāda saistība varētu būt līdzīga ar kardiovaskulāro saslimšanu un depresijas attīstības hipotēzi. Tiem kardiovaskulāriem pacientiem, kuriem ir depresija, tā varētu būt kā marķieris izteiktākam kardiovaskulāram bojājumam vai disfunkcijai, ko ar pašreiz pieejamām sirds struktūras un funkcijas novērtēšanas metodēm vēl nav iespējams klasificēt un pierādīt (Hare et al., 2014). Turklāt šīs neatgriezeniskās izmaiņas galvas smadzenēs arī varētu izskaidrot to, kāpēc pacientiem ar vaskulāru depresiju ir vājāka atbilde uz tās ārstēšanu (Aizenstein et al., 2016). Protams, š̄is ir tikai hipotēzes, kuras nepieciešams apstiprināt vai noraidīt citos pētījumos.

Lai novērtētu AVSDzK pacientiem ar nozīmīgām galvas smadzeņu asinsvadu stenozēm pirms un pēc terapijas, šobrīd nav nevienas validētas slimībai specifiskas (diseasespecific PROMs) skalas šai pacientu grupai (Essatetal. 2017). Tāpēc literatūrā tiek rekomendēta SF-36 skalas pielietošana asinsvadu ķirurğijā līdz tiks izveidots validēts, slimībai specifisks ASDzK novērtēšanas instruments (Shanetal. 2015). Lai gan SF-36v2 novērtē dažādus AVSDzK domēnus, tomēr neviens no tiem nav specifisks tikai un vienīgi 
kādai no šajā pētījumā analizētām slimnieku grupām. SAPPHIRE pētījuma autori AVSDzK noteikšanai izvēlējās 4 (PF, RP, BP, VT) no astoņiem SF-36 skalas domēniem, jo vinuuprāt, tieši šiem domēniem varētu būt vislielāka sensitivitāte, lai noteiktu AVSDzK atš̌kirības starp miega artērijas stentēšanas un endarterektomijas grupām (Stolker et al. 2010). Tomēr diemžēl pētījuma autori nenorādīja nevienu pamatojumu vai pierādījumu savai izvēlei. Tāpēc pašlaik nav ticamu pierādījumu par kāda SF-36v2 domēna specifiskumu, kas būtu vairāk informatīvs nekā pārējie domēni nozīmīgas miega artērijas stenozes pacientiem.

Ar veselību saistītas dzīves kvalitātes datu analīze uzrāda, ka pacientiem, kuriem veica MEA, visu domēnu vidējās SF-36v2 vērtības statistiski nozīmīgi nemainījās ne pēc 6, ne pēc 12 mēnešiem, salīdzinot ar vērtībām pirms operācijas. Miega artērijas stentēšanas grupā SF-36v2 vidējās vērtības arī nemainījās gada laikā, izņemot BP domēnā, kur zemākie rādītāji bija pēc 12 mēnešiem salīdzinot ar vidējām vērtībām pirms PTA. Taču medikamentozā grupā RP, BP, RE un MCS vidējās vērtības bija zemākas pēc 6 un 12 mēnešiem, salīdzinot ar SF-36v2 vidējām vērtībām uzsākot pētījumu. Mūsu pētījuma dati sakrīt ar literatūras pārskata un metaanalīzes datiem, kas apkopoja informāciju par AVSDzK pēc revaskularizācijas. Šis pētījumu apkopojums uzrāda, ka pacientiem pēc MEA un PTA saglabājas dzīves kvalitāte tādā pašā līmenī kā pirms procedūras, tas ir, tā netiek būtiski ietekmēta (Shan et al., 2015; Chabowski et al., 2017). Viens no izskaidrojumiem, kāpēc AVSDzK nemainās, varētu būt tāds, ka lielākā daļa pacientu bija ar asimptomātisku miega artērijas stenozi MEA+MT un PTA+MT grupās, bet pacienti ar simptomātisku miega artērijas stenozi bija pārcietuši TIL vai CI bez ievērojama funkcionāla deficīta $(\mathrm{mRS} \leq 2)$. Tāpēc tas ir saprotams, kāpēc AVSDzK nevar būt labāka pēc miega artērijas revaskularizācijas nekā tā bija pirms tās, galvenokārt asimptomātiskiem pacientiem, kam miega artērijas revaskularizācija bija vairāk kā išēmiska insulta profilaktiska procedūra (Shan et al., 2015). Taču pretēji MEA+MT un PTA+MT grupām, daži AVSDzK domēni, tai skaitā MCS, medikamentozā grupā pasliktinājās. MT grupā pacienti, kuri atteicās no miega artērijas revaskularizācijas, iespējams šaubījās par izdarīto izvēli, vai arī viņiem bija nemiers par iespējamo risku išēmiskam notikumam, kas attiecīgi varēja ietekmēt viņu emocionālo un mentālo dzīves kvalitāti. Iemesls, kāpēc pasliktinājās RP vērtība MT grupā iespējams varētu būt saistīts ar to, ka šajā pētījuma grupā vairāk bija vecāki un simptomātiskas miega artērijas stenozes pacienti $(p=0,072)$. Ir zināms, ka simptomātiskas miega artērijas stenozes pacientiem neiroloǵiskais deficīts jeb stāvoklis var pakāpeniski pasliktināties hroniskas hipoperfūzijas dēḷ, jo galvas smadzeņu plasticitāte ir vēl vairāk ierobežota ne tikai išēmijas, bet arī hipoperfūzijas dēḷ. Pēc līdz̄ịa principa galvas smadzeṇu plasticitātes ierobežojumi hipoperfūzijas dēḷ būtu attiecināmi arī uz pacientiem ar asimptomātisku miega artērijas stenozi, jo medikamentozā terapija pati par sevi nevar 
ievērojami samazināt stenozes pakāpi un tādējādi uzlabot galvas smadzeņu perfūziju, veicināt kollaterāḷu veidošanos vai samazināt encefalomalācijas un neironu zudumu, kas radies hroniskas išēmijas dēḷ (Bauer, Bain \& Rasmussen, 2015).

Salīdzinot AVSDzK starp nozīmīgas miega artērijas stenozes terapijas grupām, mēs novērojām, ka pacientiem, kuriem veica MEA, dz̄ives kvalitāte bija relatīvi labāka 6 un 12 mēnešu periodā pēc operācijas salīdzinājumā ar pacientiem, kuriem veica PTA vai kuri saņēma tikai medikamentozo ārstēšanu. Sešus mēnešus pēc MEA atšķirības bija vērojamas tieši PF, RP un PCS domēnos. Savukārt pēc 12 mēnešiem - augstāki rādītāji PF un SF domēnos bija MEA+MT grupā salīdzinājuma ar PTA+MT un MT grupu. Daži pētījumi ir salīdzinājuši AVSDzK pēc MEA un PTA pacientiem ar nozīmīgu miega artērijas stenozi. Lielākā daļa pētîjumu pierāda, ka nav būtiskas atškirības nevienā no SF-36v2 domēniem 1 gada laikā starp MEA un PTA grupām (CaRESS Steering Committee, 2005; Stolker et al., 2010; Cohen et al., 2011), kas savukārt nesakrīt ar mūsu pētījuma datiem. Izskaidrojums šīm atšķirīibām ir tāds, ka mūsu pētījuma pacientiem PTA+MT grupā vairāk bija kardiovaskulārās saslimšanas - koronāra sirds slimība, hroniska sirds mazspēja III un IV pakāpe pēc NYHA, perifēro artēriju slimība un cukura diabēts. Ir zināms, ka dzīves kvalitāte ir sliktāka pacientiem ar kardiovaskulāriem riska faktoriem nekā pacientiem ar citām hroniskām saslimšanām, jo KSS ir saistīta ar vislielāko AVSDzK pasliktināšanos fiziskās funkcionēšanas un vispārējās veselības novērtējumā (J.R. \& Swenson, 2004; Martinelli et al., 2008). Turklāt PTA+MT grupā novērošanas periodā BP domēna vērtības samazinājās, norādot uz sāpju pieaugumu, kas savukārt izskaidrotu to, kāpēc PCS vērtības šajā grupā bija sliktākas nekā MEA+MT grupā.

Salīdzinot AVSDzK starp PTA+MT un MT grupām 6 un 12 mēnešu periodā, statistiski nozīmīgas atšķirības netika novērotas. Izskaidrojums varētu būt līdzīgs iepriekš jau minētam, tas ir, PTA+MT grupā vairāk bija pacienti ar kardiovaskulārām saslimšanām, tāpēc AVSDzK uzlabošanās nebija novērota jo fiziskā funkcionālā nespēja ierobežo veikt ikdienas aktivitātes, tādējādi ievērojami samazina dz̄̄ves kvalitāti.

Lai gan šīs pētījums nav randomizēts kontrolēts pētījums, tomēr šis pētījums ir pirmais pētījums, kas ilgtermiṇā novērtēja AVSDzK pacientiem ar nozīmīgu miega artērijas stenozi pēc revaskularizācijas un medikamentozās ārstēšanas. Carta et al. ir pêtījis dz̄ives kvalitāti pacientiem, kuriem veica MEA un tiem, kuri atteicās no ķirurǵiskas ārstēšanas, tāpēc saṇēma tikai medikamentozu ārstēšanu. Dzīves kvalitāte tika novērtēta izmantojot SF-12 skalu 6 mēnešus pēc iekḷaušanas pētījumā. Šì pētījuma rezultāti rāda, ka statistiski nozīmīga atšķirīiba starp grupām dzīves kvalitātes rādītāju izmaiņās nebija, lai gan tika novērota tendence, ka MEA grupā dz̄ives kvalitātes rādītāji pēc 6 mēnešiem bija augstāki nekā 
medikamentozajā grupā (Carta et al., 2015). Taču šie rezultāti jāvērtē ar piesardzību mazā pacienta skaita dēḷ.

Viens no š̄ pētījuma trūkumiem ir dažādais pacientu skaits pētāmās grupās, kā arī atšķirīibas klīniskajos parametros starp grupām. Lai gan statistiski nozīmīgas atš̌şirības nebija, tomēr PTA+MTgrupā bija vairāk pacienti ar kardiovaskulārām saslimšanām, savukārt MT grupā bija vairāk pacienti ar simptomātisku miega artērijas stenozi. Šo klīnisko parametru atšķirīibu iemesls varētu būt tas, ka šis nebija randomizēts kontrolēts pētījums. Taču, lai uzlabotu rezultātu interpretāciju, statistiskos aprēķinos un datu interpretācijā tika izmantots efekta lielums, lai noteiktu statistisko atšķirību nozīmīgumu vai lielumu. Otrs šī pētījuma trūkums - netika veikta galvas samadzeņu attēldiagnostika pirms un pēc revaskularizācijas vai pētījuma laikā. Tas ierobežoja veikt precīzu asimptomātiskas un simptomātiskas miega artērijas stenozes un perioperatīvu notikumu biežuma noteikšanu, jo nereti pavisam nelieli klīniski simptomi tiek ignorēti no pacientu puses. Tomēr tā kā lielākā daļa līdzīgu klīnisko pētījumu arī neizmantoja attēldiagnostiku miega artērijas stenozes klasificēšanā, tad š̄̄ pētījuma rezultātus ir iespējams salīdzināt ar citiem pētījumiem. Visbeidzot, ne visi pētījumā iekļautie pacienti varēja piedalīties visās novērošanas vizītēs. Tāpēc tika salīdzināti šo pacientu klīniskie parametri uzsākot pētījumu ar pacientiem, kuri ierādās uz visām vizītēm. Analizēti tika tikai MEA+MT grupas pacienti lielāka pacientu skaita dēḷ. Ne klīniskais raksturojums, ne kognitīvās funkcijas, ne depresijas simptomu izmaiņas pacientiem, kuri neieradās uz atkārtotu V2 vizīti, būtiski neatšķīrās no pacientiem, kuri ieradās. Izṇemot to, ka pacientiem, kuri neieradās, SF-36v2 MH domēna novērtējumā bija nedaudz augstāki rādītāji, kas liecina par miera un emocionālo labsajūtu. Savukārt salīdzinot pacientus, kuri neieradās uz V3 vizīti pēc gada, tika novērots, ka tās biežāk bija sievietes un CD pacienti, lai gan jāņem vērā, ka šo atšķirīibu statistiskā efekta lielums bija mazs. Atšķirīibas nebija ne kognitīvās funkcijas, ne depresijas simptomu novērtējumā. Salīdzinot SF-36v2 rezultātus, konstatēja, ka pacientiem, kuri neieradās pēc gada, zemākas vidējās vērtības bija PF un PCS domēnos. Tas liek domāt, ka uz gada vizīti neieradās tie pacienti, kuriem bija fiziski grūti ierasties, ietekmējot PF un PCS domēnu rezultātus. Tomēr iemeslus viṇu fiziskās funkcionēšanas ierobežojumiem precīzi nav iespējams norādīt. Nav zināms, vai tas bija saistīts ar nozīmīgu miega artērijas stenozi, kardiovaskulāru saslimšanu vai arī ar citu saslimšanu, piemēram, artrītu. Tāpēc nepieciešami turpmāki pētījumi, kur šos faktorus būtu jāņem vērā, lai iegūtu precīzāku informāciju par kognitīvās funkcijas, depresijas simptomu un AVSDzK izmain̄ām pēc miega artērijas stenozes ārstēšanas.

Neskatoties uz iepriekšminētiem šī pētījuma trūkumiem, š̄ pētījuma priekšrocība ir tāda, ka šajā pētījumā iekḷauto pacientu skaits medikamentozajā grupā ir lielākais, kas šobrīd 
pieejams literatūrā. Turklāt šajā pētījumā mēs novērtējām ne tikai kognitīvās funkcijas izmaiņas, bet arī depresijas simptomu sastopamības un AVSDzK izmaiņas ilgtermiņā pacientiem ar nozīmīgu miega artērijas stenozi pēc revaskularizācijas un medikamentozās ārstēšanas. Šis pētījums dod ieskatu par kognitīvās funkcijas, depresijas simptomu, dzīves kvalitātes izmaiṇām ilgtermiṇā līdz randomizēti kontrolētu pētījumu rezultātu publicēšanai. Kā arī, š̄ pētîjuma laikā tika izvirzīti jautājumi un hipotēzes, ko būtu nepieciešams pierādīt un/vai ņemt vērā turpmākos līdzīgos pētījumos. 


\section{SECINĀJUMI}

1. Primāro nelabvēlīgo notikumu biežums pēc miega artērijas endarterektomijas bija 2,5\%, tādējādi nepārsniedzot vadlīnijās rekomendēto. Par šo rādītāju citās pētāmās grupās nevar izteikties mazā pacientu skaita dēḷ. Restenožu biežums statistiski nozīmīgi neatšķīrās starp revaskularizācijas grupām. Medikamentozās terapijas grupā noz̄īmīgas miega artērijas stenozes palielināšanās netika novērota. Sekundāri nelabvēlīgi iznākumi biežāk bija novērojami endovaskulārās revaskularizācijas grupā.

2. Klīniski nozīmīgas miega artērijas revaskularizācija bija saistīta ar kopējās kognitīvās funkcijas uzlabošanos pēc viena gada, turklāt endarterektomjas grupā agrīnākā periodā, jau pēc 6 mēnešiem. Savukārt pacientiem, kuri saņēma tikai medikamentozu ārstēšanu, pārliecinoša kognitīvās funkcijas uzlabošanās vai pasliktināšanās gada laikā netika novērota.

3. Depresijas simptomu biežums gada laikā pēc miega artērijas revaskularizācijas vai medikamentozās ārstēšanas ticami nemazinājās. Novērota tikai tendence depresijas simptomu sastopamībai mazināties pēc endarterektomijas.

4. Ar veselību saistītā dzīves kvalitāte pacientiem pēc miega artērijas endarterektomijas nemainījās. Tomēr endovaskulārās revaskularizācijas un medikamentozās terapijas grupās pēc gada novērota pasliktināšanās tādos domēnos kā sāpes, fiziskā funkcionēšana, fiziskās veselības stāvokḷa ietekme uz darbu un citām ikdienas aktivitātēm, psihiskās veselības vispārējais stāvoklis. Ticamāk, tas vairāk saistīts ar lielāku vecumu, augstāku blakussaslimšanu biežumu šais grupās, nevis ar terapijas metodi.

5. Atšksirībā no pacientiem, kuri saņēma tikai medikamentozu ārstēšanu, pacientiem pēc nozīmīgas miega artērijas revaskularizācijas novēroja kopējās kognitīvās funkcijas uzlabošanos. Savukārt retāki depresijas simptomi un labāka ar veselību saistīta dzīves kvalitāte bija gadu pēc endarterektomijas, bet ne pēc miega artērijas stentēšanas vai tikai medikamentozās terapijas. 


\section{PRAKTISKĀS REKOMENDĀCIJAS}

1. Pētījuma laika periodā biežāk veica endarterektomiju asimptomātiskiem zema ķirurǵiska riska pacientiem, kas šobrīd ir pretrunā ar 2018. gada vadlīnijām. Tāpēc šī pētījuma rezultāti varētu aktualizēt nepieciešamību veikt endarterktomiju simptomātiskiem pacientiem, bet asimptomātiskiem pacientiem pirms revaskularizācijas ir jāizvērtē ne tikai ķirurǵijas, bet arī išēmiska insulta risks.

2. Miega artērijas stenoze varētu būt kā viens no modificējamiem riska faktoriem kognitīviem traucējumiem, tāpēc bez perioperatīva insulta un nāves riska novērtēšanas kritērijiem, būtu nepieciešams novērtēt arī kognitīvās funkcijas izmaiņas pacientiem ar nozīmīgu miega artērijas stenozi.

3. Līdzịgi kā kardiovaskulāro slimību pacientiem, depresijas simptomu novērtēšana ikdienas klīniskā praksē būtu nepieciešama arī nozīmīgas miega artērijas stenozes pacientiem.

4. N̦emot vērā, ka ar veselību saistītā dzīves kvalitāte nepasliktinās pēc miega artērijas stenozes revaskularizācijas, tad š̄i informācija būtu vērā ņemama, pieṇemot lēmumu par miega artērijas stenozes ārstēšanas veidu. 


\section{IZMANTOTĀ LITERATŪRA}

1. ACTRIS. 2018.Endarterectomy Combined With Optimal Medical Therapy (OMT) vs OMT Alone in Patients With Asymptomatic Severe Atherosclerotic Carotid Artery Stenosis at Higherthan-average Risk of Ipsilateral Stroke (ACTRIS). www.clinicaltrials. gov NCT02841098. Available at: https://clinicaltrials.gov/ct2/show/NCT02841098 [Accessed: 20 March 2018].

2. Aguiar de Sousa, D. et al.2019. Access to and delivery of acute ischaemic stroke treatments: A survey of national scientific societies and stroke experts in 44 European countries. European Stroke Journal. 4(1), 13-28. doi: 10.1177/2396987318786023.

3. Ahmed, B., Al-Khaffaf, H. 2009. Prevalence of Significant Asymptomatic Carotid Artery Disease in Patients with Peripheral Vascular Disease: A Meta-Analysis. European Journal of Vascular and Endovascular Surgery. 37(3), 262-271. doi: 10.1016/j.ejvs.2008.10.017.

4. Ahn, S. H., Prince, E. A. and Dubel, G. J. 2013. Carotid artery stenting: Review of technique and update of recent literature. Seminars in Interventional Radiology. 30(3), 288-296. doi: 10.1055/s0033-1353482.

5. Aizenstein, H. J. et al. 2016. Vascular depression consensus report - a critical update. BMC Medicine. 14(1), 161. doi: 10.1186/s12916-016-0720-5.

6. Aleksic, M. et al. 2006. Cognitive Function Remains Unchanged After Endarterectomy of Unilateral Internal Carotid Artery Stenosis Under Local Anaesthesia. European Journal of Vascular and Endovascular Surgery. 31(6), 616-621. doi: 10.1016/j.ejvs.2005.12.012.

7. Alexopoulos, G. S. et al. 1997. "Vascular depression" hypothesis. Archives of general psychiatry. 54(10), 915-22. doi: 10.1001/archpsyc.1997.01830220033006.

8. Alosco, M. L. et al.2013. The adverse effects of reduced cerebral perfusion on cognition and brain structure in older adults with cardiovascular disease. Brain and Behavior. 3(6), 626-636. doi: $10.1002 /$ brb3.171.

9. Altinbas, A. et al.2011. Cognition after carotid endarterectomy or stenting: A randomized comparison. Neurology. 77(11), 1084-1090. doi: 10.1212/WNL.0b013e31822e55b9.

10. American Psychiatric Association. 2013.Diagnostic and Statistical Manual of Mental Disorders, Fifth Edition. American Psychiatric Association. doi: 10.1176/appi.books.9780890425596.

11. Antonopoulos, C. N. et al.2015. The impact of carotid artery stenting on cognitive function in patients with extracranial carotid artery stenosis. Annals of Vascular Surgery. 29(3), 457-469. doi: 10.1016/j.avsg.2014.10.024.

12. Balucani, C. et al.2012. Cerebral hemodynamics and cognitive performance in bilateral asymptomatic carotid stenosis. Neurology, 79(17), 1788-1795.

doi:10.1212/WNL.0b013e318270402e.

13. Baracchini, C. et al. 2012. Carotid endarterectomy protects elderly patients from cognitive decline: A prospective study. Surgery. 151(1), 99-106. doi: 10.1016/j.surg.2011.06.031.

14. Barnes, D. E. et al.2006. Depressive Symptoms, Vascular Disease, and Mild Cognitive Impairment. Arch Gen Psychiatry. 63, 273-280.doi:10.1001/archpsyc.63.3.273.

15. Barnett, H. et al.1998. Benefit of Carotid Endarterectomy in patients with symptomatic moderate or severe stenosis. The New England Journal of Medicine. 339(20), 1415-1425. doi:10.1056/NEJM199811123392002.

16. Bárrios, H. et al.2013. Quality of life in patients with mild cognitive impairment. Aging \& Mental Health. 17(3), 287-292. doi: 10.1080/13607863.2012.747083.

17. Bauer, A. M., Bain, M. D. and Rasmussen, P. A. 2015. Chronic Cerebral Ischemia: Where "Evidence-Based Medicine" Fails Patients. World Neurosurgery. 84(3), 714-718. doi: 10.1016/j.wneu.2015.04.049. 
18. Baumgart, M. et al. 2015. Summary of the evidence on modifiable risk factors for cognitive decline and dementia: A population-based perspective. Alzheimer's and Dementia. 11(6), 718-726. doi: 10.1016/j.jalz.2015.05.016.

19. Behrouz, R., Malek, A. R. and Torbey, M. T. 2012. Small vessel cerebrovascular disease: The past, present, and future. Stroke Research and Treatment. 2012, 839151. doi:10.1155/2012/839151.

20. Béjot, Y. et al. 2016. Epidemiology of stroke in Europe and trends for the 21st century. Presse Medicale. 45(12), e391-e398. doi: 10.1016/j.lpm.2016.10.003.

21. Bennett, M. R., Sinha, S. and Owens, G. K. 2016. Vascular Smooth Muscle Cells in Atherosclerosis. Circulation Research. 118(4), 692-702. doi:10.1161/CIRCRESAHA.115.306361.

22. Berwick, D. M. et al.1991. Performance of a five-item mental health screening test. Medical care. 29(2), 169-76. doi:10.1097/00005650-199102000-00008.

23. Beutel, M. E. et al.2014. History of depression but not current depression is associated with signs of atherosclerosis: data from the Gutenberg Health Study. Psychological Medicine. 44(05), 919-925. doi: 10.1017/S0033291713001542.

24. Biesbroek, J. M. et al.2013. Association between Subcortical Vascular Lesion Location and Cognition: A Voxel-Based and Tract-Based Lesion-Symptom Mapping Study. The SMART-MR Study. PloS One. 8(4), p. e60541. doi: 10.1371/journal.pone.0060541.

25. Bocti, C. et al.2013. Vascular cognitive impairment: most useful subtests of the Montreal Cognitive Assessment in minor stroke and transient ischemic attack. Dementia and geriatric cognitive disorders. 36(3-4), 154-62. doi: 10.1159/000351674.

26. Bonati, L. et al.2012. Percutaneous transluminal balloon angioplasty and stenting for carotid artery stenosis. The Cochrane database of systematic reviews. 9(9). Available from: https://www.cochranelibrary.com. doi: 10.1002/14651858.CD000515.pub2

27. Bonati, L. H. and Brown, M. M. 2015. Carotid Artery Disease. In Stroke: Pathophysiology, Diagnosis, and Management, 6th Edition. Grotta, J., et al., eds. Elsevier, 326-346. doi: 10.1016/B978-0-323-29544-4.00022-0.

28. Boström, K. I. 2016. Where do we stand on vascular calcification? Vascular Pharmacology. 84, 8-14. doi: 10.1016/j.vph.2016.05.014.

29. Bourque, J. M. and Kramer, C. M. 2011. Noninvasive Imaging of Atherosclerosis. In Cardiovascular Imaging. Ho, V., and Reddy, G. 1st Edition., Saunders, 1193-1214.

30. de Bray, J. and Glatt, B. 1995. Quantification of Atheromatous stenosis in the Extracranial Internal Artery. Cerebrovasc Dis. 5, 414-426. doi:10.1159/000107895.

31. Brinjikji, W. et al.2016. Plaque Vulnerability. Journal of Neurosurgery. 124(1), 27-42. doi: 10.3171/2015.1.JNS142452.

32. Brott, T. G. et al.2010. Stenting versus Endarterectomy for Treatment of Carotid-Artery Stenosis. The New England Journal of Medicine. 363(1), 11-23. doi: 10.1056/NEJMoa0912321.

33. Brott, T. G. et al.2011. ASA/ACCF/AHA/AANN/AANS/ACR/ASNR/CNS/SAIP/SCAI/SIR/ SNIS/SVM/SVS Guideline on the Management of Patients With Extracranial Carotid and Vertebral Artery Disease: A Report of the American College of Cardiology Foundation/American Heart Association Task F. Circulation. 124(4), e54-e130. doi: 10.1161/CIR.0b013e31820d8c98.

34. Bulbulia, R. and Halliday, A. 2017. The asymptomatic carotid surgery trial-2 (ACST-2): An ongoing randomised controlled trial comparing carotid endarterectomy with carotid artery stenting to prevent stroke. Health Technology Assessment. 21(57), 1-40. doi: 10.3310/hta21570.

35. Buratti, L. et al.2014. Cognitive deterioration in bilateral asymptomatic severe carotid stenosis. Stroke. 45(7), 2072-2077. doi: 10.1161/STROKEAHA.114.005645. 
36. CaRESS Steering Committee, 2005. Carotid Revascularization Using Endarterectomy or Stenting Systems (CaRESS) phase I clinical trial: 1-Year results. Journal of Vascular Surgery. 42(2), 213219. doi: 10.1016/j.jvs.2005.04.023.

37. Carod-Artal, F. J. and Egido, J. A. 2009. Quality of Life after Stroke: The Importance of a Good Recovery. Cerebrovascular Diseases. 27(1), 204-214. doi: 10.1159/000200461.

38. Carta, M. G. et al.2015. Patients with carotid atherosclerosis who underwent or did not undergo carotid endarterectomy: outcome on mood, cognition and quality of life. BMC Psychiatry. 15 (277). doi: 10.1186/s12888-015-0663-y.

39. Chabowski, M. et al. 2017. Quality of life after carotid endarterectomy: a review of the literature. Acta Neurologica Belgica. 1-7. doi: http://dx.doi.org/10.1007/s13760-017-0811-x.

40. Chambers, B. R. and Donnan, G. A. 2005. Carotid endarterectomy for asymptomatic carotid stenosis. The Cochrane database of systematic reviews. doi: 10.1002/14651858.CD001923.pub2.

41. Chen, C. I. et al. 2006. Analysis of emboli during carotid stenting with distal protection device. Cerebrovascular Diseases. 21(4), 223-228. doi: 10.1159/000091218.

42. Ciesielska, N. et al.2016. Is the Montreal Cognitive Assessment (MoCA) test better suited than the Mini-Mental State Examination (MMSE) in mild cognitive impairment (MCI) detection among people aged over 60? Meta-analysis. Psychiatria Polska. 50(5), 1039-1052. doi: $10.12740 / \mathrm{PP} / 45368$.

43. Cohen, D. J. et al.2011. Health-related quality of life after carotid stenting versus carotid endarterectomy: Results from CREST (Carotid Revascularization Endarterectomy versus Stenting Trial). Journal of the American College of Cardiology. 58(15), 1557-1565. doi: 10.1016/j.jacc.2011.05.054.

44. Consoli, A., Pasi, M. and Pantoni, L. 2012. Vascular mild cognitive impairment: concept, definition, and directions for future studies. Aging Clinical and Experimental Research. 24(2), 113-116. doi: 10.1007/BF03325158.

45. Cooley, S. A. et al.2015. Longitudinal change in performance on the Montreal Cognitive Assessment in older adults. Clin Neuropsychol. 29(6), 824-835. doi: 10.1080/13854046.2015.1087596.

46. Cosottini, M. et al.2005. Silent cerebral ischemia detected with diffusion-weighted imaging in patients treated with protected and unprotected carotid artery stenting. Stroke. 36(11), 2389-2393. doi: 10.1161/01.STR.0000185676.05358.f2.

47. Coumans, J. V. C. E. and McGrail, K. M. 2000. Psychiatric presentation of carotid stenosis. Surgery. 127(6), 713-715. doi: 10.1067/msy.2000.105035.

48. CREST-2 Trial. (2014) Carotid Revascularization and Medical Management for Asymptomatic Carotid Stenosis Trial. Available at: https://clinicaltrials.gov/ct2/results?pg=1\&load=cart\&id= NCT02089217 [Accessed: 13 January 2019].

49. Cumming, T. B. et al.2013. Montreal cognitive assessment and mini-mental state examination are both valid cognitive tools in stroke. Acta Neurologica Scandinavica. 128(2), 122-129. doi: 10.1111/ane.12084.

50. Daneshi, A. et al.2004. Pulsatile Tinnitus and Carotid Artery Atherosclerosis. International Tinnitus Journal. 10(2), 161-164. doi: 10.1016/j.anl.2016.12.004.

51. Debiec, J., Ledoux, J. E. and Nader, K. 2002. Cellular and Systems Reconsolidation in the Hippocampus. Neuron. 36, 527-538. doi:10.1016/s0896-6273(02)01001-2.

52. Dempsey, R. et al.2010. A Review of Carotid Atherosclerosis and Vascular Cognitive Decline: A New Understanding of the Keys to Symptomology Robert. Neurosurgery. 67(2), 484-494. doi: 10.1227/01.NEU.0000371730.11404.36.

53. Dempsey, R. J., Varghese, T., et al.2017. Carotid atherosclerotic plaque instability and cognition determined by ultrasound-measured plaque strain in asymptomatic patients with significant stenosis. Journal of Neurosurgery. 1-9. doi: 10.3171/2016.10.JNS161299. 
54. Dempsey, R. J., Jackson, D. C., et al.2017. The Preservation of Cognition 1 Yr After Carotid Endarterectomy in Patients With Prior Cognitive Decline. Neurosurgery.1; 83(3), 322-328. doi: 10.1093/neuros/nyx173.

55. Dhawan, S. S. et al.2010. Shear stress and plaque development. Expert Review of Cardiovascular Therapy. 8(4), 545-556. doi: 10.1586/erc.10.28.

56. Dichgans, M., Leys, D. 2017. Vascular Cognitive Impairment. Circulation Research. 120(3), 573-591. doi: 10.1161/CIRCRESAHA.116.308426.

57. Direk, N. et al.2012. Cerebral hemodynamics and incident depression: The rotterdam study. Biological Psychiatry. 72(4), 318-323. doi: 10.1016/j.biopsych.2012.01.019.

58. Dotson, V. M. et al.2009. Longitudinal study of chronic depressive symptoms and regional cerebral blood flow in older men and women. International Journal of Geriatric Psychiatry. 24(8), 809-819. doi: 10.1002/gps.2298.

59. Essat, M. et al.2018. Patient-Reported Outcome Measures in Carotid Artery Revascularisation: Systematic Review and Psychometric Analysis. Annals of Vascular Surgery. 50(7), 275-283. doi: 10.1016/j.avsg.2017.12.008.

60. Eurostat, 2018. Population structure and ageing. Available at: https://ec.europa.eu/eurostat/statistics-explained/index.php/Population_structure_and_ageing [Accessed: 25 November 2018].

61. Faramawi, M. F. et al. 2007. Relation Between Depressive Symptoms and Common Carotid Artery Atherosclerosis in American Persons $\geq 65$ Years of Age. The American Journal of Cardiology, 99(11), 1610-1613. doi: 10.1016/j.amjcard.2006.12.090.

62. Faxon, D. P. et al.2004. Atherosclerotic vascular disease conference. Writing group III: Pathophysiology. Circulation, 109(21), 2617-2625. doi: 10.1161/01.CIR.0000128520.37674.EF.

63. Fearn, S. J. et al.2003. Carotid endarterectomy improves cognitive function in patients with exchausted cerebrovascular reserve. European Journal of Vascular and Endovascular Surgery. 26(5), 529-536. doi: 10.1016/S1078-5884(03)00384-8.

64. Feigin, V. L. et al.2016. Global burden of stroke and risk factors in 188 countries, during 19902013: a systematic analysis for the Global Burden of Disease Study 2013. The Lancet Neurology. 15(9), 913-924. doi: 10.1016/S1474-4422(16)30073-4.

65. Feliziani, F. T. et al.2010. Cognitive performance in elderly patients undergoing carotid endarterectomy or carotid artery stenting: A twelve-month follow-up study. Cerebrovascular Diseases. 30(3), 244-251. doi: 10.1159/000319066.

66. Ference, B. A. et al.2017. Low-density lipoproteins cause atherosclerotic cardiovascular disease. 1. Evidence from genetic, epidemiologic, and clinical studies. A consensus statement fromthe European Atherosclerosis Society Consensus Panel. European Heart Journal. 38(32), 24592472. doi: 10.1093/eurheartj/ehx144.

67. Fischer, U. et al.2010. What is a minor stroke?. Stroke. 41(4), 661-666. doi: 10.1161/STROKEAHA.109.572883.

68. Fisher CM, Gore I, Okabe N, W. P. 1965. Atherosclerosis of the carotid and vertebral arteries Extracranial and intracranial. J Neumpathol Exp Neurol.24(3), 455-476. doi:10.1097/00005072196507000-00007.

69. Fisher, M. et al.2005. Carotid plaque pathology: Thrombosis, ulceration, and stroke pathogenesis. Stroke. 36(2), 253-257. doi: 10.1161/01.STR.0000152336.71224.21.

70. Flaherty, M. L. et al.2014. Carotid Artery Stenosis as a Cause of a Stroke. 40(1), 36-41. doi: 10.1159/000341410.Carotid.

71. Ghogawala, Z. et al.2013. The effect of carotid endarterectomy on cerebral blood flow and cognitive function. Journal of Stroke and Cerebrovascular Diseases. 22(7), 1029-1037. doi: 10.1016/j.jstrokecerebrovasdis.2012.03.016. 
72. Gimbrone, M. A. and García-Cardeña, G. 2013. Vascular endothelium, hemodynamics, and the pathobiology of atherosclerosis. Cardiovascular Pathology. 22(1), 9-15. doi: 10.1016/j.carpath.2012.06.006.

73. Grau, A. J. et al.2001. Risk Factors, Outcome and Treatment in Subtypes of Ischemic Stroke: The German Stroke Data Bank. Stroke, 32, 2559-2566. doi: 10.1161/hs1101.098524.

74. Gressier, F. et al. 2011. Drug-Resistant Major Depression Associated With Carotid Artery Stenosis. American Journal of Psychiatry. 168(4), 439-439. doi: 10.1176/appi.ajp.2010.10101497.

75. Gupta, A. et al.2012. Cerebrovascular reserve and stroke risk in patients with carotid stenosis or occlusion: A systematic review and meta-analysis. Stroke. 43(11), 2884-2891. doi: 10.1161/STROKEAHA.112.663716.

76. Hachinski, V., Lassen, N. and Marshall, J. 1974. Multi-infarct dementia. A cause of mental deterioration in the elderly. The Lancet. 2, 207-210. doi:10.1016/s0140-6736(74)91496-2.

77. Hackett, M. L. and Pickles, K. 2014. Part I: Frequency of Depression after Stroke: An Updated Systematic Review and Meta-Analysis of Observational Studies. International Journal of Stroke. 9(8), 1017-1025. doi: 10.1111/ijs.12357.

78. Hadar, N. et al.2014. Asymptomatic carotid artery stenosis treated with medical therapy alone: Temporal trends and implications for risk assessment and the design of future studies. Cerebrovascular Diseases. 38(3), 163-173. doi: 10.1159/000365206.

79. Halliday, A. et al.2010. 10-year stroke prevention after successful carotid endarterectomy for asymptomatic stenosis (ACST-1): A multicentre randomised trial. The Lancet. 376(9746), 10741084. doi: 10.1016/S0140-6736(10)61197-X.

80. Halliday, A. W., Thomas, D. and Mansfiel, A. 1994.The Asymptomatic Carotid Surgery Trial (ACST) Rationale and Design. European Journal of Vascular Surgery. 8(6), 703-710. doi: 10.1016/S0950-821X(05)80650-4.

81. Hare, D. L. et al.2014. Depression and cardiovascular disease: A clinical review. European Heart Journal, 35(21), 1365-1372. doi: 10.1093/eurheartj/eht462.

82. Hobson, R. W. et al.1993. Efficacy of Carotid Endarterectomy for Asymptomatic Carotid Stenosis. N Engl J Med. 329, 221-7. doi: 10.1016/S0002-9149(99)00324-0.

83. Hofmann, R. et al.2005. Coronary angiography in patients undergoing carotid artery stenting shows a high incidence of significant coronary artery disease. Heart. 91(11), 1438-1441. doi: 10.1136/hrt.2004.050906.

84. Hommel, M., Carey, L. and Jaillard, A. 2015.Depression: Cognition relations after stroke. International Journal of Stroke. 10(6), 893-896. doi: 10.1111/ijs.12057.

85. Horne, D. et al.2013. Depression before and after cardiac surgery: Do all patients respond the same? Journal of Thoracic and Cardiovascular Surgery. 145(5), 1400-1406. doi: 10.1016/j.jtcvs.2012.11.011.

86. Hörnsten, C. et al.2016. The prevalence of stroke and depression and factors associated with depression in elderly people with and without stroke. BMC geriatrics. 16(1), 174. doi: 10.1186/s12877-016-0347-6.

87. Howard, V. J. et al.2017. Carotid revascularization and medical management for asymptomatic carotid stenosis: Protocol of the CREST-2 clinical trials. International Journal of Stroke. 12(7), 770-778. doi: 10.1177/1747493017706238.

88. Huang, C. C. et al.2013. Association of the recovery of objective abnormal cerebral perfusion with neurocognitive improvement after carotid revascularization. Journal of the American College of Cardiology, 61(25), 2503-2509. doi: 10.1016/j.jacc.2013.02.059.

89. Huffman, J. C. et al.2013. Depression and Cardiac Disease : Epidemiology, Mechanisms, and Diagnosis.Cardiovasc Psychiatry Neurol. 2013:695925. doi:10.1155/2013/695925. 
90. Iadecola, C. 2013. The pathobiology of vascular dementia. Neuron. 80(4), 844-866. doi: 10.1016/j.neuron.2013.10.008.

91. Inzitari, D. et al.2000. The Causes and Risk of Stroke in Patients with Asymptomatic Internal-Carotid-Artery Stenosis. New England Journal of Medicine. 342(23), 1693-1701. doi: 10.1056/NEJM200006083422302.

92. J.R., S. and Swenson, J. R. 2004.Quality of life in patients with coronary artery disease and the impact of depression. Current Psychiatry Reports. 6(6), 438-445. doi:10.1007/s11920-004-0008$\mathrm{x}$.

93. Jackson, D. C. et al.2015. Cognitive Deficits in Symptomatic and Asymptomatic Carotid Endarterectomy Surgical Candidates. Archives of clinical neuropsychology: the official journal of the National Academy of Neuropsychologists, 31(1), 1-7. doi: 10.1093/arclin/acv082.

94. Jellinger, K. A. 2008. Morphologic diagnosis of "vascular dementia " - A critical update. 270, (1-2) 1-12. doi: 10.1016/j.jns.2008.03.006.

95. Johnston, S. C. et al.2004. Cognitive Impairment and Decline Are Associated with Carotid Artery Disease in Patients without Clinically Evident Cerebrovascular Disease. Annals of Internal Medicine. 140(4), 237-247. doi: 10.1177/153100350501700224.

96. Kakkos, S. K. et al.2017. Endarterectomy achieves lower stroke and death rates compared with stenting in patients with asymptomatic carotid stenosis. Journal of Vascular Surgery. 66(2), 607-617. doi: 10.1016/j.jvs.2017.04.053.

97. Kamondi, A. and Szirmai, I. 2002. Strategic infarcts of the thalamus in vascular dementia. J.Neurol Sci. 203- 204, 91-97. doi:10.1016/s0022-510x(02)00273-3.

98. Ketelhuth, D. F. J. and Bäck, M. 2011. The role of matrix metalloproteinases in atherothrombosis. Current Atherosclerosis Reports. 13(2), 162-169. doi: 10.1007/s11883-010-0159-7.

99. Kim, J. J. et al.2015. Comparison of neurocognitive outcomes after carotid endarterectomy and carotid artery stenting. American Surgeon, 81(10), 1010-1014.

100. Kim, S. et al.2016. Factors related to prevalence, persistence, and incidence of depressive symptoms in mild cognitive impairment: vascular depression construct. International Journal of Geriatric Psychiatry. 31(7), 818-826. doi: 10.1002/gps.4400.

101. Kishikawa, K. et al.2003. Effects of carotid endarterectomy on cerebral blood flow and neuropsychological test performance in patients with high-grade carotid stenosis. Journal of the Neurological Sciences. 213(1-2), 19-24. doi: 10.1016/S0022-510X(03)00128-X.

102. Kita, T. et al.2001. Role of oxidized LDL in atherosclerosis. Annals of the New York Academy of Sciences. 947, 199-205; discussion 205-206. doi: 10.1111/j.1749-6632.2001.tb03941.x.

103. Kolominsky-Rabas, P. L. et al.2001. Epidemiology of Ischemic Stroke Subtypes According to TOAST Criteria. Incidence, recurrence and long term survival in ischemic stroke subtypes: A population - based study. Stroke. 32(12), 2735-2741. doi:10.1161/hs1201.100209.

104. Koski, L. 2013. Validity and applications of the montreal cognitive assessment for the assessment of vascular cognitive impairment. Cerebrovascular Diseases. 36(1), 6-18. doi: $10.1159 / 000352051$.

105. Kougias, P. et al. 2015. Comparison of domain-specific cognitive function after carotid endarterectomy and stenting. Journal of Vascular Surgery. 62(2), 355-362. doi: 10.1016/j.jvs.2015.02.057.

106. Krishnan, K. et al.2016. Changes in Montreal Cognitive Assessment Scores Over Time. Assessment. 24(6), 772-777. doi: 10.1177/1073191116654217.

107. Kroenke, K. and Spitzer, R. L. 2002. The PHQ-9: A New Depression Diagnostic and Severity Measure. Psychiatric Annals. 32(9), 509-515. doi: 10.3928/0048-5713-20020901-06. 
108. Kroenke, K., Spitzer, R. L. and Williams, J. B. W. 2001. The PHQ-9: Validity of a brief depression severity measure. Journal of General Internal Medicine. 16(9), 606-613. doi: 10.1046/j.1525-1497.2001.016009606.x.

109. Kung, S. et al.2013. Comparing the beck depression inventory-II (BDI-II) and Patient Health Questionnaire (PHQ-9) depression measures in an integrated mood disorders practice. Journal of Affective Disorders. 145(3), 341-343. doi: 10.1016/j.jad.2012.08.017.

110. Kutlubaev, M. A. and Hackett, M. L. 2014. Part II: Predictors of depression after stroke and impact of depression on stroke outcome: An updated systematic review of observational studies. International Journal of Stroke. 9(8), 1026-1036. doi: 10.1111/ijs.12356.

111. Lal, B. K. et al. 2002. Pixel distribution analysis of B-mode ultrasound scan images predicts histologic features of atherosclerotic carotid plaques. Journal of Vascular Surgery. 35(6), 1210-1217. doi: 10.1067/mva.2002.122888.

112. Lal, B. K., Dux, M. C., et al. 2017. Asymptomatic carotid stenosis is associated with cognitive impairment. Journal of Vascular Surgery. 1-10. doi: 10.1016/j.jvs.2017.04.038.

113. Lal, B. K., Meschia, J. F., et al.2017. Carotid Stenting Versus Carotid Endarterectomy: What Did the Carotid Revascularization Endarterectomy Versus Stenting Trial Show and Where Do We Go from Here? Angiology. 68(8), 675-682. doi: 10.1177/0003319716661661.

114. Lam, B. et al.2013. Criterion and convergent validity of the montreal cognitive assessment with screening and standardized neuropsychological testing. Journal of the American Geriatrics Society. 61(12), 2181-2185. doi: 10.1111/jgs.12541.

115. Latvijas Neirologu Biedrība et al.2013.Cerebrāla infarkta prehospitālās aprūpes, diagnostikas un akūtas ārstēšanas klīniskās vadlīnijas. pp. 1-102. Available at: https://spkc.gov.lv/uploads/files/53ea62fbb4d4e.pdf [Accessed February 8, 2015].

116. Lee, S. R. et al.2015. Depressive-Like Behaviors in a Rat Model of Chronic Cerebral Hypoperfusion. Translational Stroke Research. 6(3), 207-214. doi: 10.1007/s12975-014-0385-3.

117. Li, Y. et al.2017. Long-term efficacy and safety of carotid artery stenting versus endarterectomy: A meta-analysis of randomized controlled trials. Plos One. 12(7), e0180804. doi: 10.1371/journal.pone.0180804.

118. Lin, C. J. et al.2016. Intervention versus Aggressive Medical Therapy for Cognition in Severe Asymptomatic Carotid Stenosis. Am J Neuroradiol, 37(10), 1889-97. doi: 10.3174/ajnr.A4798.

119. Loscalzo, J. 2001. Nitirc Oxide Insufficiency, Platelet Activation and Arterial Thrombosis. Circulation Research. 88 (8), 756-763. doi: 10.1161/hh0801.089861.

120. Luebke, T. and Brunkwall, J. 2016. Carotid artery stenting versus carotid endarterectomy: updated meta-analysis, metaregression and trial sequential analysis of short-term and intermediate-to long-term outcomes of randomized trials.The Journal of cardiovascular surgery. 57(4), 519-39. Available at: http://www.ncbi.nlm.nih.gov/pubmed/26883249 [Accessed: 20 March 2018].

121. Luijendijk, H. J. et al.2011. Transient ischemic attack and incident depression. Stroke. 42(7), 1857-1861. doi: 10.1161/STROKEAHA.110.604405.

122. Maki, Y. et al. 2014.The impact of subjective memory complaints on quality of life in community-dwelling older adults. Psychogeriatrics. 14(3), 175-181. doi: 10.1111/psyg.12056.

123. Maleux, G. et al. 2006. Cerebral ischemia after filter-protected carotid artery stenting is common and cannot be predicted by the presence of substantial amount of debris captured by the filter device. American Journal of Neuroradiology. 27(9), 1830-1833. doi: 10.1016/S07494041(08)70855-8.

124. De Man-Van Ginkel, J. M. et al.2012. An efficient way to detect poststroke depression by subsequent administration of a 9-item and a 2-item patient health questionnaire. Stroke, 43(3), 854-856. doi: 10.1161/STROKEAHA.111.640276. 
125. Marquardt, L. et al.2010. Low risk of ipsilateral stroke in patients with asymptomatic carotid stenosis on best medical treatment: A prospective, population-based study. Stroke. 41(1), 11-17. doi: 10.1161/STROKEAHA.109.561837.

126. Marshall, R. S. et al.2012. Cerebral hemodynamics and cognitive impairment: Baseline data from the RECON trial. Neurology. 78(4), 250-255. doi: 10.1212/WNL.0b013e31824365d3.

127. Martin, K. C., Barad, M. and Kandel, E. R. 2000. Local protein synthesis and its role in synapsespecific plasticity. Current Opinion in Neurobiology. 10(5), 587-592. doi: 10.1016/S09594388(00)00128-8.

128. Martin, P. et al.1998. Health-related quality of life after transient ischemic attack and minor stroke: is medical or surgical treatment influential? Journal of Stroke and Cerebrovascular Diseases. 7(1), 70-75. doi: 10.1016/S1052-3057(98)80024-4.

129. Martinelli, L. M. B. et al.2008. Quality of life and its association with cardiovascular risk factors in a community health care program population. Clinics. 63(6), 783-788. doi: 10.1590/S180759322008000600013.

130. Mast, B. T. et al.2004. Risk Factors for Geriatric Depression: The Importance of Executive Functioning Within the Vascular Depression Hypothesis. Journal of Gerontology: Medical Sciences, 59(12), 1290-1294. doi: 10.1093/gerona/59.12.1290.

131. Mathiesen, E. B. et al.2004. Reduced neuropsychological test performance in asymptomatic carotid stenosis: The Tromso Study. Neurology. 62(5), 695-701. doi: 10.1212/01.WNL.0000113759.80877.1F.

132. Mathiesen, E. B., Joakimsen, O. and Bonaa, K. H. 2001. Prevalence of and risk factors associated with carotid artery stenosis: the Tromso Study. Cerebrovasc Dis. 12(1), 44-51. doi: $10.1159 / 000047680$.

133. McLaren, J. E. et al.2011. Cytokines, macrophage lipid metabolism and foam cells: Implications for cardiovascular disease therapy. Progress in Lipid Research. 50(4), 331-347. doi: 10.1016/j.plipres.2011.04.002.

134. Meier, P. et al.2010. Short term and intermediate term comparison of endarterectomy versus stenting for carotid artery stenosis: Systematic review and meta-analysis of randomised controlled clinical trials. BMJ (Online). 340(7744), p. 459. doi: 10.1136/bmj.c467.

135. Mlekusch, W. et al.2006. Is there improvement of "vascular depression" after carotid artery stent placement? Radiology. 240(2), 508-514. doi: 10.1148/radiol.2402051043.

136. Moresoli, P. et al.2017. Carotid Stenting Versus Endarterectomy for Asymptomatic Carotid Artery Stenosis. Stroke. 48(8), 2150-2157. doi: 10.1161/STROKEAHA.117.016824.

137. Morris, D. R. et al.2017. Evidence-Based Carotid Interventions for Stroke Prevention: State-ofthe-art Review. Journal of Atherosclerosis and Thrombosis. 24(4), 373-387. doi: $10.5551 /$ jat.38745.

138. Mott, M., Koroshetz, W. and Wright, C. B. 2017. CREST-2: Identifying the Best Method of Stroke Prevention for Carotid Artery Stenosis: National Institute of Neurological Disorders and Stroke Organizational Update. Stroke. 48(5), e130-e131. doi: 10.1161/STROKEAHA.117.016051.

139. Muller, M. et al.2011. Carotid atherosclerosis and progression of brain atrophy: The SMARTMR Study. Annals of Neurology. 70(2), 237-244. doi: 10.1002/ana.22392.

140. Murray, C. J. L. and GBD Disease and Injury Incidence and Prevalence Collaborators, 2017. Global, regional, and national incidence, prevalence, and years lived with disability for 328 diseases and injuries for 195 countries, 1990-2016: A systematic analysis for the Global Burden of Disease Study 2016. The Lancet. 390(10100), 1211-1259. doi: 10.1016/S01406736(17)32154-2.

141. Narasimhalu, K. et al.2009. Severity of CIND and MCI predict incidence of dementia in an ischemic stroke cohort. Neurology. 73(22), 1866-72. doi: 10.1212/WNL.0b013e3181c3fcb7. 
142. Nasreddine, Z. et al.2005. The Montreal Cognitive Assessment, MoCA: a brief screening tool for mild cognitive impairment. Journal of the American Geriatrics Society. 53(4), 695-699. doi: 10.1111/j.1532-5415.2005.53221.x.

143. Nasreddine Ziad, 2015.MoCA Instruction Latvian. Available at: http://www.mocatest.org/wpcontent/uploads/2015/tests-instructions/MoCA-Instruction-Latvian.pdf [Accessed: 30 April 2017].

144. Naylor, A. R.2015. Why is the management of asymptomatic carotid disease so controversial? Surgeon. 13(1), 34-43. doi: 10.1016/j.surge.2014.08.004.

145. Naylor, A. R. et al.2018. Management of Atherosclerotic Carotid and Vertebral Artery Disease: 2017 Clinical Practice Guidelines of the European Society for Vascular Surgery (ESVS). European Journal of Vascular and Endovascular Surgery. 55(1), 3-81. doi: 10.1016/j.ejvs.2017.06.021.

146. Naylor, A. R., Sillesen, H. and Schroeder, T. V. 2015. Clinical and imaging features associated with an increased risk of early and late stroke in patients with symptomatic carotid disease. European Journal of Vascular and Endovascular Surgery. 49(5), 513-523. doi: 10.1016/j.ejvs.2015.01.011.

147. North American Symptomatic Carotid Endarterectomy Trial Colaborators. 1991. Beneficial Effect of Carotid endarterectomy in Simptomatic Patients with High-Grade Carotid Stenosis. The New England Journal of Medicine. 325(7), 445-453. doi: 10.1056/NEJM199108153250701.

148. Oates, C. P. et al.2009. Joint Recommendations for Reporting Carotid Ultrasound Investigations in the United Kingdom. European Journal of Vascular and Endovascular Surgery. 37(3), 251-261. doi: 10.1016/j.ejvs.2008.10.015.

149. Oda, K. et al.2003. Regional cerebral blood flow in depressed patients with white matter magnetic resonance hyperintensity. Biological Psychiatry. 53(2), 150-156. doi: 10.1016/S00063223(02)01548-2.

150. OECD/European Observatory on Health Systems and Policies (2017), Latvia: Country Health Profile 2017, State of Health in the EU. State of Health in the EU. pp. 1-20. doi: 10.1787/9789264283466-en.

151. Ois, A. et al.2009. High risk of early neurological recurrence in symptomatic carotid stenosis. Stroke. 40(8), 2727-2731. doi: 10.1161/STROKEAHA.109.548032.

152. Optum (2008a) An excerpt from the User's Manual for the SF-36v2 Health Survey, Second Edition, Deciding Which Short Form Survey to Use. Available at: https://campaign.optum.com/content/dam/optum/resources/Manual Excerpts/Which-Survey-ToUse.pdf [Accessed: 30 April 2018].

153. Optum (2008b) PART I: INTRODUCTION An excerpt from the User's Manual for the SF-36v2 Health Survey, Second Edition, Chapter 1, pages 3-12. Available at: https://campaign.optum.com/content/dam/optum/resources/ManualExcerpts/SF-36v2_Manual_ Chapter_1.pdf [Accessed: 30 April 2018].

154. Optum (2015) SF-36 Health Survey Latvian and Russian version - Optum.com. Available at: https://campaign.optum.com/optum-outcomes/what-we-do/health-surveys/sf-36v2-healthsurvey.html (Accessed: 3 March 2015).

155. Orrapin, S. and Rerkasem, K. 2017. Carotid endarterectomy for symptomatic carotid stenosis. Cochrane Database of Systematic Reviews, (6), Art. No.: CD001081. doi: 10.1002/14651858.CD001081.pub3.

156. Palm, F. et al. 2012. Etiology, risk factors and sex differences in ischemic stroke in the ludwigshafen stroke study, a population-based stroke registry. Cerebrovascular Diseases. 33(1), 69-75. doi: 10.1159/000333417.

157. Pantoni, L. 2010. Cerebral small vessel disease: from pathogenesis and clinical characteristics to therapeutic challenges. The Lancet Neurology. 9(7), 689-701. doi: 10.1016/S14744422(10)70104-6. 
158. Paraskevas, K. I. et al.2014. Comparison of cognitive function after carotid artery stenting versus carotid endarterectomy. European Journal of Vascular and Endovascular Surgery. 47(3), 221231. doi: 10.1016/j.ejvs.2013.11.006.

159. Pasternak, R. C. et al.2004. Atherosclerotic vascular disease conference. Writing group I: Epidemiology. Circulation. 109(21), 2605-2612. doi: 10.1161/01.CIR.0000128518.26834.93.

160. Pendlebury, S. T. et al.2012. MoCA, ACE-R, and MMSE versus the national institute of neurological disorders and stroke-canadian stroke network vascular cognitive impairment harmonization standards neuropsychological battery after TIA and stroke. Stroke. 43(2), 464-469. doi: 10.1161/STROKEAHA.111.633586.

161. Petersen, R. C. 2011. Clinical practice. Mild cognitive impairment. The New England Journal of Medicine. 364(23), 2227-2234. doi: 10.1056/NEJMcp0910237.

162. Petty, G. W. et al.1999. Ischemic stroke subtypes: A Population-Based Study of Incidence and Risk Factors. Stroke. 30(12), 2513-2516. doi: 10.1161/01.str.30.12.2513.

163. PHQ-9 Instruction Manual (2015) INSTRUCTION MANUAL Instructions for Patient Health Questionnaire (PHQ) and GAD-7 Measures. Available at: https://phqscreeners.pfizer.edrupalgardens.com/sites/g/files/g10016261/f/201412/instructions.pdf [Accessed: 7 April 2018].

164. Plessers, M. et al.2015. Prospective comparison of cognitive effects of carotid endarterectomy versus carotid stenting with flow reversal or distal filters. Journal of Clinical and Experimental Neuropsychology. 37(8), 834-841. doi: 10.1080/13803395.2015.1060952.

165. Popovic, I. M. et al.2011. Cognitive Performance in Asymptomatic Patients with advanced carotid disease. Cog Behav Neurol, 224(3), 145-151. doi: 10.1097/WNN.0b013e3182313020.

166. Prins, N. D. and Scheltens, P. 2015. White matter hyperintensities, cognitive impairment and dementia: an update. Nature Reviews Neurology. 11(3), 157-165. doi: 10.1038/nrneurol.2015.10.

167. Prugger, C. et al.2015. Longitudinal association of carotid plaque presence and intima-media thickness with depressive symptoms in the elderly: the three-city study. Arterioscler Thromb Vasc Biol. 35(5), 1279-1283. doi: 10.1161/atvbaha.114.305061.

168. Pucite, E. et al.2017. Influence of Severe Carotid Stenosis on Cognition, Depressive Symptoms and Quality of Life'. Clinical Practice \& Epidemiology in Mental Health. 13(1), 168-180. doi: 10.2174/1745017901713010168.

169. Purandare, N. 2009. Preventing dementia: Role of vascular risk factors and cerebral emboli. British Medical Bulletin. 91(1), 49-59. doi: 10.1093/bmb/ldp020.

170. De Rango, P. et al.2008. The role of carotid artery stenting and carotid endarterectomy in cognitive performance: A systematic review. Stroke. 39(11), 3116-3127. doi: 10.1161/STROKEAHA.108.518357.

171. Rice, C. C. et al.2009. Absence of Relation between Depressive Symptoms and Carotid Intimal Medial Thickness in the Baltimore Longitudinal Study of Aging. Psychosom Med. 71(1), 70-76. doi: 10.3816/CLM.2009.n.003.Novel.

172. Ricotta, J. J. et al.2011. Updated Society for Vascular Surgery guidelines for management of extracranial carotid disease. Journal of Vascular Surgery. 54(3), e1-e31. doi: 10.1016/j.jvs.2011.07.031.

173. Robinson, R. G. 2006. The Clinical Neuropsychiatry of Stroke. Second Edi. Edited by R. Robinson. Cambridge: New York, Cambridge University Press. doi: 10.1017/CBO9780511544231.

174. Robinson, R. G. and Jorge, R. E. 2016. Post-stroke depression: A review.American Journal of Psychiatry. 173(3), 221-231. doi: 10.1176/appi.ajp.2015.15030363.

175. Romero, J. R. et al.2009. Carotid artery atherosclerosis, MRI indices of brain ischemia, aging, and cognitive impairment: The framingham study. Stroke. 40(5), 1590-1596. doi: 10.1161/STROKEAHA.108.535245. 
176. Rosenfield, K. et al.2016. Randomized Trial of Stent versus Surgery for Asymptomatic Carotid Stenosis. The New England journal of medicine. 374(11), 1011-20. doi: 10.1056/NEJMoa1515706.

177. Ross, R. 1999. Atherosclerosis - An Inflammatory Disease. New England Journal of Medicine. 340(2), 115-126. doi: 10.1056/NEJM199901143400207.

178. Rothwell, P. M. et al.1994. Equivalence of Measurements of Carotid Stenosis: A Comparison of Three Methods on 1001 Angiograms. American Heart Association. 25(12), 2435-2439. doi:10.1161/01.str.25.12.2453.

179. Rothwell, P. M. et al.2003. Analysis of pooled data from the randomised controlled trials of endarterectomy for symptomatic carotid stenosis. Lancet.361(9352), 107-16. doi: 10.1016/S0140-6736(03)12228-3.

180. Sachdev, P. S. et al.2014. Diagnostic criteria for vascular cognitive disorders: a VASCOG statement. Alzheimer disease and associated disorders. 28(3), 206-218. doi: 10.1109/TMI.2012.2196707.Separate.

181. Sakakura, K. et al.2013. Pathophysiology of atherosclerosis plaque progression. Heart Lung and Circulation. 22(6), 399-411. doi: 10.1016/j.hlc.2013.03.001.

182. Salaycik, K. J. et al.2007. Depressive Symptoms and Risk of Stroke: The Framingham Study. Stroke. 38(1), 16-21. doi: 10.1161/01.STR.0000251695.39877.ca.

183. Sandu, R. E. et al.2015. Neuroinflammation and comorbidities are frequently ignored factors in CNS pathology. Neural Regeneration Research. 10(9), 1349-1355. doi: 10.4103/16735374.165208.

184. Sansone, R. A. and Sansone, L. A. 2012. Rumination: Relationships with Physical Health. Innovative Clinical Neuroscience. 9(2), 29-34. Available at: http://www.ncbi.nlm.nih.gov/pmc/articles/PMC3312901/. [Accessed 15 May, 2018].

185. Saris-Baglama, R. N. et al.2011. QualityMetric Health Outcomes ${ }^{\mathrm{TM}}$ Scoring Software 4.0 User's Guide', Health (San Francisco), 1-138.

186. Seldenrijk, A. et al.2011. Carotid atherosclerosis in depression and anxiety: Associations for age of depression onset. World Journal of Biological Psychiatry. 12, 549-558. doi: $10.3109 / 15622975.2011 .583942$.

187. Selim, M. H. and Molina, C. A. 2011. Medical versus surgical treatment of asymptomatic carotid stenosis: The ever-changing nature of evidence-based medicine. Stroke. 42(4), 1156-1157. doi: 10.1161/STROKEAHA.111.614156.

188. Setacci, C. et al.2017. Device selection for carotid stenting: reviewing the evidence. Expert Review of Cardiovascular Therapy. 15(10), 787-796. doi: 10.1080/14779072.2017.1364627.

189. Shan, L. et al.2015. Quality of Life and Functional Status After Carotid Revascularisation: A Systematic Review and Meta-Analysis. European Journal of Vascular \& Endovascular Surgery. 49, 634-645. doi: 10.1016/j.ejvs.2015.03.020.

190. Shi, Y. and Wardlaw, J. M. 2016. Update on cerebral small vessel disease: A dynamic wholebrain disease. Stroke and Vascular Neurology. 1(3), 83-92. doi: 10.1136/svn-2016-000035.

191. Silvestrini, M. et al.2009. Cerebral hemodynamics and cognitive performance in patients with asymptomatic carotid stenosis. Neurology, 72 (12), 1062-1068. doi: 10.1212/01.wnl.0000345015.35520.52.

192. Sismanis, A. 1998. Pulsatile tinnitus : A 15-year experience. The American Journal of Otology, $19,472-477$.

193. Sivertsen, H. et al.2015. Depression and quality of life in older persons: A review. Dementia and Geriatric Cognitive Disorders. 40(5-6), 311-339. doi: 10.1159/000437299. 
194. van Sloten, T. T. et al.2016. Associations between arterial stiffness, depressive symptoms and cerebral small vessel disease: Cross-sectional findings from the AGES-Reykjavik study. Journal of Psychiatry and Neuroscience. 41(3), 162-168. doi: 10.1503/jpn.140334.

195. De Smedt, D., Clays, E. and De Bacquer, D. 2016. Measuring health-related quality of life in cardiac patients. European Heart Journal - Quality of Care and Clinical Outcomes. 2(3), 149150. doi: 10.1093/ehjqcco/qcw015.

196. Sneed, J. R. and Culang-Reinlieb, M. E. 2011. The vascular depression hypothesis: an update. The American journal of geriatric psychiatry. 19(2), 99-103. doi: 10.1097/JGP.0b013e318202fc8a

197. Steffens, D. and Fisher, G. 2009. Prevalence of depression among older Americans: the Aging, Demographics and Memory Study David. Int Psychogeriatr. 21(5), 879-888. doi: 10.1017/S1041610209990044.Prevalence.

198. Stein, J. H. et al.2008. Use of Carotid Ultrasound to Identify Subclinical Vascular Disease and Evaluate Cardiovascular Disease Risk: A Consensus Statement from the American Society of Echocardiography Carotid Intima-Media Thickness Task Force Endorsed by the Society for Vascular. Journal of the American Society of Echocardiography. 21(2), 93-111. doi: 10.1016/j.echo.2007.11.011.

199. Stephens, S. et al.2004. Neuropsychological characteristics of mild vascular cognitive impairment and dementia after stroke. International Journal of Geriatric Psychiatry. 19(11), 1053-1057. doi: 10.1002/gps.1209.

200. Stolker, J. M. et al.2010. Health-related quality of life following carotid stenting versus endarterectomy: Results from the SAPPHIRE (Stenting and Angioplasty with Protection in Patients at HIgh Risk for Endarterectomy) trial. JACC: Cardiovascular Interventions. 3(5), 515523. doi: 10.1016/j.jcin.2010.02.009.

201. Stroke Research Group, 2018.The European Carotid Surgery Trial 2 (ECST-2) Protocol Summary: Version 3.10. Available at: http://s489637516.websitehome.co.uk/ECST2/protocolsummary.htm [Accessed: 2 December 2018].

202. Sulženko, J. and Pieniazek, P. 2018. The cardiovascular risk of patients with carotid artery stenosis. Cor et Vasa. 60(1), e42-e48. doi: 10.1016/j.crvasa.2017.09.006.

203. Sun, J.-H., Tan, L. and Yu, J.-T. 2014. Post-stroke cognitive impairment: epidemiology, mechanisms and management. Annals of translational medicine. 2(8), 80. doi: 10.3978/j.issn.2305-5839.2014.08.05.

204. Tabas, I., García-Cardeña, G. and Owens, G. K. 2015. Recent insights into the cellular biology of atherosclerosis. Journal of Cell Biology. 209(1), 13-22. doi: 10.1083/jcb.201412052.

205. Takaya, N. et al.2006. Association between carotid plaque characteristics and subsequent ischemic cerebrovascular events: A prospective assessment with MRI - Initial results. Stroke. 37(3), 818-823. doi: 10.1161/01.STR.0000204638.91099.91.

206. Tang, E. Y. H. et al. 2018. Longitudinal effect of stroke on cognition: A systematic review. Journal of the American Heart Association. 7(2). doi: 10.1161/JAHA.117.006443.

207. Taylor, W. D., Aizenstein, H. J. and Alexopoulos, G. S. 2013. The vascular depression hypothesis: mechanisms linking vascular disease with depression. Molecular psychiatry. 18(9), 963-74. doi: 10.1038/mp.2013.20.

208. Ter Telgte, A. et al.2018. Cerebral small vessel disease: From a focal to a global perspective. Nature Reviews Neurology. 14(7), 387-398. doi: 10.1038/s41582-018-0014-y.

209. Tendera, M. et al.2011. ESC Guidelines on the diagnosis and treatment of peripheral artery diseases: Document covering atherosclerotic disease of extracranial carotid and vertebral, mesenteric, renal, upper and lower extremity arteries * The Task Force on the Diagnosis and Treatment. European Heart Journal. 32(22), 2851-2906. doi: 10.1093/eurheartj/ehr211. 
210. Teng, E., Tassniyom, K. and Lu, P. H. 2012. Reduced Quality of Life Ratings in Mild Cognitive Impairment: Analyses of Subjects and Informant Responses. Am J Geriatr Psychiatry. 20(12), 1016-1025. doi: 10.1097/JGP.0b013e31826ce640.

211. Tiemeier, H. et al. 2004. Relationship Between Atherosclerosis and Late-Life Depression. Archives of General Psychiatry. 61(4), 369-376. doi: 10.1001/archpsyc.61.4.369.

212. Truelsen, T. et al.2006. Stroke incidence and prevalence in Europe: A review of available data. European Journal of Neurology. 13(6), 581-598. doi: 10.1111/j.1468-1331.2006.01138.x.

213. U.S. Department of Health and Human Services FDA Center for Drug Evaluation and Research. 2006. Guidance for industry: Patient-reported outcome measures: Use in medical product development to support labeling claims: Draft guidance. Health and Quality of Life Outcomes. 4, 1-20. doi: 10.1186/1477-7525-4-79.

214. VanderLaan, P. A., Reardon, C. A. and Getz, G. S. 2004. Site Specificity of Atherosclerosis: SiteSelective Responses to Atherosclerotic Modulators. Arteriosclerosis, Thrombosis, and Vascular Biology. 24(1), 12-22. doi: 10.1161/01.ATV.0000105054.43931.f0.

215. Vincent, S. et al.2015. Meta-analysis of randomized controlled trials comparing the long-term outcomes of carotid artery stenting versus endarterectomy. Circulation: Cardiovascular Quality and Outcomes. 8(6_suppl_3), S99-S108. doi: 10.1161/CIRCOUTCOMES.115.001933.

216. Vlajinac, H. et al.2013. Health-related quality of life among patients with symptomatic carotid disease. Postgraduate medical journal. 89(1047), 8-13. doi: 10.1136/postgradmedj-2012131005 .

217. Vrublevska, J., Trapencieris, M. and Rancans, E. 2018. Adaptation and validation of the Patient Health Questionnaire-9 to evaluate major depression in a primary care sample in Latvia. Nordic Journal of Psychiatry. 72(2), 112-118. doi: 10.1080/08039488.2017.1397191.

218. Walker, M. D. et al. 1995. Endarterectomy for asymptomatic carotid artery stenosis. Executive Committee for the Asymptomatic Carotid Atherosclerosis Study. JAMA: the Journal of the American Medical Association. 273(18), 1421-8. doi: 10.1001/jama.1995.03520420075042.

219. Wang, T. et al.2017. The impact of carotid artery stenting on cerebral perfusion, functional connectivity, and cognition in severe asymptomatic carotid stenosis patients. Frontiers in Neurology. 8(AUG), 1-7. doi: 10.3389/fneur.2017.00403.

220. Wang, T. and Butany, J. 2017. Pathogenesis of atherosclerosis. Diagnostic Histopathology. 23(11), 473-478. doi: 10.1016/j.mpdhp.2017.11.009.

221. Wang, T., Mei, B. and Zhang, J. 2016. Atherosclerotic carotid stenosis and cognitive function. Clinical Neurology and Neurosurgery. 146(2016), 64-70. doi: 10.1016/j.clineuro.2016.03.027.

222. Wapp, M. et al.2015. Cognitive improvement in patients with carotid stenosis is independent of treatment type. Swiss Medical Weekly. 145(12), 1-7. doi: 10.4414/smw.2015.14226.

223. Wardlaw, J. M. et al.2006. Accurate, practical and cost-effective assessment of carotid stenosis in the UK. Health technology assessment. 10(30). doi: 10.3310/hta10300.

224. Ware, J. et al.2008.SF36v2 Health Survey: Administration guide for clinical trial investigators. Lincoln, RI: QualityMetric Incorporated.https://www.optum.com/solutions/life-sciences/answerresearch/patient-insights/sf-health-surveys/sf-36v2-health-survey.html[Accessed: 30 April 2015].

225. Ware, J. E. J. and Sherbourne, C. D. 1992. The MOS 36-ltem Short-Form Health Survey (SF-36): I. Conceptual framework and item selection. Medical Care. 30(6), 473-83. doi: 10.1097/00005650-199206000-00002.

226. Warlow, C. 1991. MRC European Carotid Surgery Trial: interim results for symptomatic patients with severe (70-99\%) or with mild (0-29\%) carotid stenosis. The Lancet. 337(8752), 1235-1243. doi: 10.1016/0140-6736(91)92916-P.

227. Watanabe, J. et al.2017. Cognitive Change 1 Year after CEA or CAS Compared with Medication. Journal of Stroke and Cerebrovascular Diseases. 26(6), 1297-1305. doi: 10.1016/j.jstrokecerebrovasdis.2017.01.024. 
228. de Weerd, M. et al. 2009. Prevalence of Asymptomatic Carotid Artery Stenosis According to Age and Sex: Systematic Review and Metaregression Analysis. Stroke. 40(4), 1105-1113. doi: 10.1161/STROKEAHA.108.532218.

229. De Weerd, M. et al.2010. Prevalence of asymptomatic carotid artery stenosis in the general population: An individual participant data meta-analysis. Stroke. 41(6), 1294-1297. doi: 10.1161/STROKEAHA.110.581058.

230. De Weerd, M. et al.2014. Prediction of asymptomatic carotid artery stenosis in the general population: Identification of high-risk groups. Stroke. 45(8), 2366-2371. doi: 10.1161/STROKEAHA.114.005145.

231. Wendell, C. R. et al.2012. Carotid atherosclerosis and prospective risk of dementia. Stroke. 43(12), 3319-3324. doi: 10.1161/STROKEAHA.112.672527.

232. Whisnant JP, Basford JR, Bernstein EF, Cooper ES, D. M. et al. 1990. Special report from the National Institute of Neurological Disorders and Stroke. Classification of cerebrovascular diseases III. Stroke. 21(4), 637-76. doi: 10.1161/STROKEAHA.107.181486.

233. White, J. et al.2016. Predictors of health-related quality of life in community-dwelling stroke survivors: a cohort study. Family Practice. 33(4), 382-387. doi: 10.1093/fampra/cmw011.

234. Wilkins, E. et al. 2017. European Cardiovascular Disease Statistics 2017 edition', European Heart Network, Brussels, p. 192. doi: 978-2-9537898-1-2.

235. Williams, J. and Kroenke, K. 2010.Pfizer To Offer Free Public Access To Mental Health Assessment Tools To Improve Diagnosis And Patient Care. Available at: http://www.pfizer.com/news/press-release/press-release-detail/pfizer_to_offer_free_public_ access_to_mental_health_assessment_tools_to_improve_diagnosis_and_patient_care.

236. Williams, L. S. et al.2005. Performance of the PHQ-9 as a screening tool for depression after stroke. Stroke. 36(3), 635-638. doi: 10.1161/01.STR.0000155688.18207.33.

237. De Wit, L. et al.2017. Long-term impact of stroke on patients' health-related quality of life. Disability and Rehabilitation. 39(14), 1435-1440. doi: 10.1080/09638288.2016.1200676.

238. Wolfe, C. D. a et al.2011. Estimates of outcomes up to ten years after stroke: analysis from the prospective South London Stroke Register. PLoS medicine. 8(5), p. e1001033. doi: 10.1371/journal.pmed.1001033.

239. Yadav, J. S. et al.2004. Protected Carotid-Artery Stenting versus Endarterectomy in High-Risk Patients. The New England journal of medicine. 351(15), 1493-1501. doi: 10.1056/NEJMoa1402685.

240. Yan, Y. et al.2014. Influence of Carotid Artery Stenting on Cognition of Elderly Patients with Severe Stenosis of the Internal Carotid Artery. Medical Science Monitor.17(20), 1461-8. doi: 10.12659/MSM.890847.

241. Zarins, C. and Gewertz, B. 2005. Atlas Of Vascular Surgery - 2nd Edition. Elsevier. 213-245.

242. Zarins, C. K. et al.1983. Carotid Bifurcation Atherosclerosis. Quantitative correlation of plaque localizatin with flow velocity profiles and wall shear stress. Circulation Research. 53(4), 502514. doi:10.1161/01.res.53.4.502.

243. Zhang, L. et al.2015. Systematic review and meta-analysis of carotid artery stenting versus endarterectomy for carotid stenosis: A chronological and worldwide study. Medicine. 94(26), 110. doi: 10.1097/MD.0000000000001060. 


\section{PUBLIKĀCIJAS UN ZIŅOJUMI PAR PĒTĪJUMA TĒMU}

\section{Publikācijas par darba tēmu:}

1. Elīna Pūcīte, Mariuss Šlisers, Evija Miglāne, Dainis Krieviņš, Andrejs Millers, Inese Blimhena, 2015. Health-related Quality of Life among Patients with Severe Carotid Artery Stenosis. Proceedings of Latvian Academy of Sciences, Section B. 69(5), 20-30. doi: 10.1515/prolas-2015-0036.

2. Pucite E., Slisers M., Miglane E., Krievins D., Erts R., Jurjans K., Krievina I, 2016. Impact of carotid endarterectomy on cognitive performance and depressive symptoms. CBU International Conference Proceedings 2016, ISE Research Institute. 4(0), 608-614. doi: 10.12955/cbup.v4.820.

3. Elina Pucite, Ildze Krievina, Evija Miglane, Renars Erts, Andrejs Millers, Dainis Krievins, 2017. Influence of Severe Carotid Stenosis on Cognition, Depressive Symptoms and Quality of Life. Clinical Practice \& Epidemiology in Mental Health. 2017. 13, 168-180. doi: 10.2174/1745017901713010168.

4. Elina Pucite, Ildze Krievina, Evija Miglane, Renars Erts, Dainis Krievins, Andrejs Millers, 2019. Changes in Cognition, Depression and Quality of Life after Carotid Stenosis Treatment. Current Neurovascular Research. 16(1): 47-62. doi: 10.2174/1567202616666190129153409.

\section{Ziṇojumi starptautiskās konferencēs:}

1. Elīna Pūcīte, Mariuss Šlisers, Evija Miglāne, Dainis Krieviņš, Andrejs Millers, Inese Blimhena. The frequency of depressive symptoms in patients with severe carotid artery disease. Poster presentation Balcone 2015, 8th Baltic Congress of Neurology, Riga, Latvia.

2. Ramona Valante, Evija Miglāne, Elīna Pūcīte, Zanda Priede, Andrejs Millers. Primary and secondary prevention among patients with initial and recurrent stroke in Latvia. $24^{\text {th }}$ European Stroke Conference in Vienna, Austria, 2015. Abstract E-book, p. 244.

3. Elīna Pūcīte, Marius Šlisers, Evija Miglāne, Dainis Krieviņš, Andrejs Millers, Jolanta Dadzìte' Ildze Krievina. Health-related quality of life among patients with severe carotid disease. $25^{\text {th }}$ European Stroke Conference in Venice, Italy, 2016.

4. Elīna Pūcīte, Reinis Ošiņš, Evija Miglāne, Andrejs Millers, Ināra Logina. Aspirin and clopidogrel resistance in patients with recurrent atherothrombotic stroke. $25^{\text {th }}$ European Stroke Conference in Venice, Italy, 2016. 
5. E. Pucite, E. Miglane, D. Krievins, A. Millers, I. Krievina. Cognitive performance and depressive symptoms in severe carotidartery patients. $3^{\text {rd }}$ European Stroke Organisation Conference 2017, Prague, Czech Republic. European Stroke Journal, Volume 2, Issue 1, suppl 2, p. 475.

6. E. Pucite, E. Miglane, A. Millers, I. Logina, A. Novasa, R. Aleksejeva. Resistence to aspirin and clopidogrel in stroke patients. $3^{\text {rd }}$ European Stroke Organisation Conference 2017, Prague, Czech Republic. European Stroke Journal, Volume 2, Issue 1, suppl 2, p. 386.

7. Elina Pucite, Ildze Krievina, Tatjana Muravska, Evija Miglane, Dainis Krievins, Andrejs Millers. Long term health-related quality of life after carotid artery revascularization or medical therapy. $9^{\text {th }}$ Baltic Congress of Neurology 2018, Kaunas, Lithuania, page 122.

8. Elina Pucite, Ildze Krievina, Tatjana Muravska, Evija Miglane, Dainis Krievins, Andrejs Millers. Effect of carotid artery revascularization on the course of cognitive function and depressive symptoms. $9^{\text {th }}$ Baltic Congress of Neurology 2018, Kaunas, Lithuania, page 123.

\section{Ziṇojumi Latvijas konferencēs un kongresos:}

1. Elīna Pūcīte, Evija Miglāne, Andrejs Millers, Zanda Priede. Cerebrāla infarkta sekundārās profilakses novērtējums. RSU Zinātniskā konference 2015.

2. Elīna Pūcīte, Marius Šlisers, Evija Miglāne, Dainis Krieviņš, Andrejs Millers, Jolanta Dadzīte, Ildze Krieviņa. Simptomātiskas un asimptomātiskas nozīmīgas miega artērijas stenozes salīdzinājums. 2016. gada RSU zinātniskā konference 2016.

3. Elīna Pūcīte, Ildze Krieviņa, Evija Miglāne, Dainis Krieviņš, Andrejs Millers. Kognitīvu traucējumu un depresijas simptomu sastopamība pacientiem ar nozìmīgu aterosklerozi. RSU Zinātniskā konference 2017. 


\section{PATEICĪBAS}

Izsaku lielu pateicību saviem darba vadītājiem - asociētajai profesorei Evijai Miglānei un profesoram Dainim Krieviņam - par piedāvājumu un iedrošinājumu veikt promocijas darbu, kā arī par atbalstu un vērtīgiem padomiem promocijas darba veidošanā.

Izsaku sirsnīgu pateicību Paula Stradiṇa Klīniskās universitātes slimnīcas Neirologijas klīnikas ārstei dr. Ildzei Krieviņai par nesavtīgu palīdzību kakla asinsvadu izmeklējumu veikšanā visa pētījuma laikā.

Paldies docentam Renāram Ertam par konsultācijām un pal̄̄dzību, veicot statistikas aprēķinus.

Pateicos arī visam Paula Stradiña Klīniskās universitātes slimnīcas Neirologiijas klīnikas kolektīvam par palīdzību, atbalstu un sapratni darba tapšanas laikā, tai skaitā dr. Tatjanai Muravskai un dr. Mariusam Šliseram.

Vislielākais paldies manai ǵimenei par neatsveramo iecietību, sapratni, palīdzību un atbalstu pētniecības radošajā procesā. 
PIELIKUMI 


\section{Ẽtikas komitejas lēmums}

Veidlapa Nr. E-9 (2)

\section{RSU ẼTIKAS KOMITEJAS LEEMUMS}

Rĩga, Dzirciema iela 16, LV-1007

Tel. 67409089

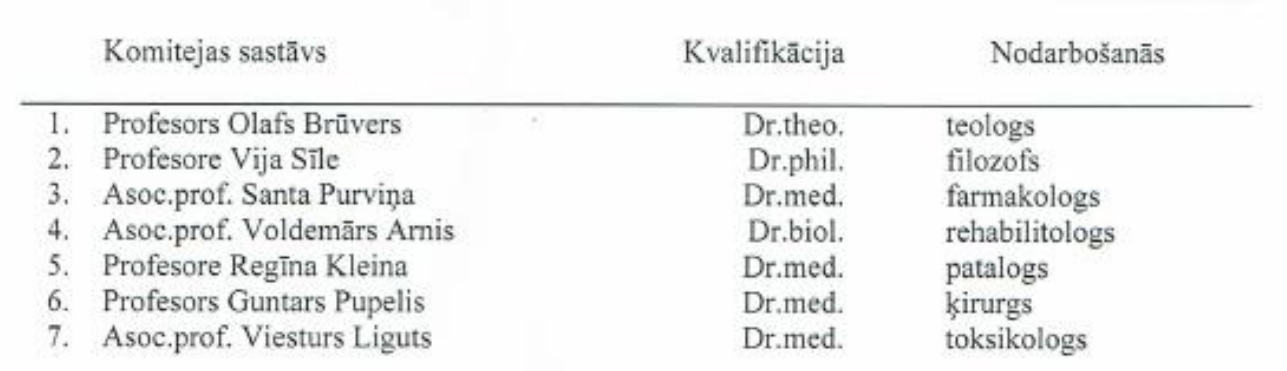

\begin{tabular}{|c|c|}
\hline Pieteikuma iesniedzējs: & $\begin{array}{l}\text { Dr. Elīna Pũcīte } \\
\text { P. Stradina Klīniskăs Universitātes slimnīca }\end{array}$ \\
\hline Pētījuma nosaukums: & $\begin{array}{l}\text { „Ar veselību saistītās dzīves kvalitătes izmainas pẽc miega } \\
\text { arterrijas nozīmīgas stenozes operatîvas un medikamentozas } \\
\text { ărstēšanas". }\end{array}$ \\
\hline Iesniegšanas datums: & 01.08.2014. \\
\hline $\begin{array}{l}\text { Pētījuma protokols: } \\
\text { (protokolu) ir redzams, k: } \\
\text { aptauju par dzīves kvalitā } \\
\text { izmantojot īpašu skalu ( } \\
\text { Personu (pacientu, dalībn } \\
\text { pētijumā un konfidencial } \\
\text { êtikas prasībām. }\end{array}$ & 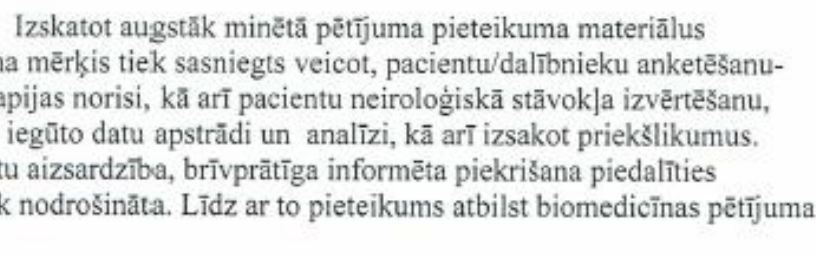 \\
\hline
\end{tabular}

Izskaidrošanas formulārs: ir

Piekrišana piedalīties pētījumā: ir

Komitejas lēmums: $\quad$ piekrist pētījumam

Komitejas priekšsēēētājs Olafs Brũvers Tituls: Dr, miss., prof.

Paraksts

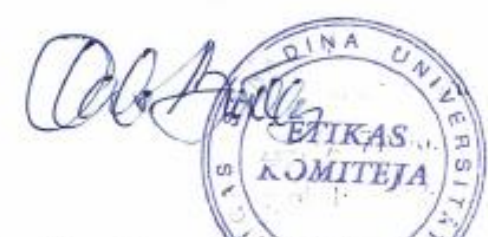

Etikas komitejas sēdes datums: 0409.2014 
2. pielikums

\section{DATU IEGŪŠANAS ANKETA}

\section{Pirms iekḷaušanas pētījumā}

1. Demogrāfiskie dati:

Pētījuma dalībnieka $\mathrm{Nr}$.:

Aizpildīšanas datums:

Dzimums:

1) Sieviete

Iniciāl̦i:

Vecums:

Kontakta tālrunis:

Ārstêts:

Stacionēšanas laiks (datumi iestājoties un izrakstoties):

Saslimšanas datums (insulta vai TIL):

\section{Iepriekš pārciestas saslimšanas:}

1. TIL:

2. Išēmisks insults ar / bez neirologíniska defekta

1)jā 2)nē

3. Hemorāğisks insults ar / bez neirologiiska defekta

1)jā 2)nē

4. Stenokardija(pakāpe)

5. MI

1)jā 2)nē

1)jā 2)nē

6. Koronāro asinsvadu stentēšana

1)jā 2)nē

7. AKS

1)jā 2)nē

8.HSM (pakāpe)

9. AH (pakāpe)

1)jā 2)nē

10. MA

11. Vārstuḷu patologiija: 1) jā

a) $\mathrm{AoV}$

1)jā 2)nē

12. Perifēro artēriju slimība (kāju a/v): 1)jā

1)jā 2)nē

13.CD 1) jā: (labu/sliktu metabolo kompensāciju; gadi)

14. Dislipidēmija

15. Smēķēšana: 1) jā: cik cigaretes dienā: 2) nē

16. Alkohola lietošana: 1) jā $\quad$ b) $<1 \times$ xmēn

17. ĶMI (garums $\mathrm{cm}$, svars

$\begin{array}{ll}\text { c) } 2-4 x m e ̄ n & \text { d)2-3x nedẹlā }\end{array}$

b)MV c)Protezēta $\quad$ d) nē

b)MV c)Protezēta d) nē

2)ne

2)nē

1)jā 2)n̄è

) cik gadus: $\mathrm{kg})=$

3. Regulāri lietotie medikamenti ambulatori PIRMS:

\begin{tabular}{|l|l|l|l|l|l|}
\hline Antihipertensīvie & Antiagreganti & Hipolipidiz.med. & Antiaritmiskie & \\
\hline Nelieto & Nelieto & Nelieto & Nelieto & \\
\hline AKE-I & Aspir̄̄ns & Stāini & Lieto & \\
\hline Sartāni & Klopidogrels & cits & & \\
\hline KKB & Antikoagulanti & Hipoglikem.med. & & \\
\hline Beta blokatori & Nelieto & Nelieto & & \\
\hline Diurêtiķi & Warfarīns & Insulīns & & \\
\hline & JPOAK & p/o & & \\
\hline
\end{tabular}

\section{NIHSS, mRS novērtējums:}

NIHSS:

mRS:

\section{Analīzes:}

\begin{tabular}{|l|l|l|l|l|l|l|l|l|l|l|l|}
\hline Kreatinīns & & GFĀ & & ALAT & & Na & & K & & Glikoze & \\
\hline CRO & & KH & & TG & & ABL & & ZBL & & Hb1Ac & \\
\hline
\end{tabular}


6. Papildu izmeklējumi:

6.1. Brahiocefālo asinsvadu izmeklējums

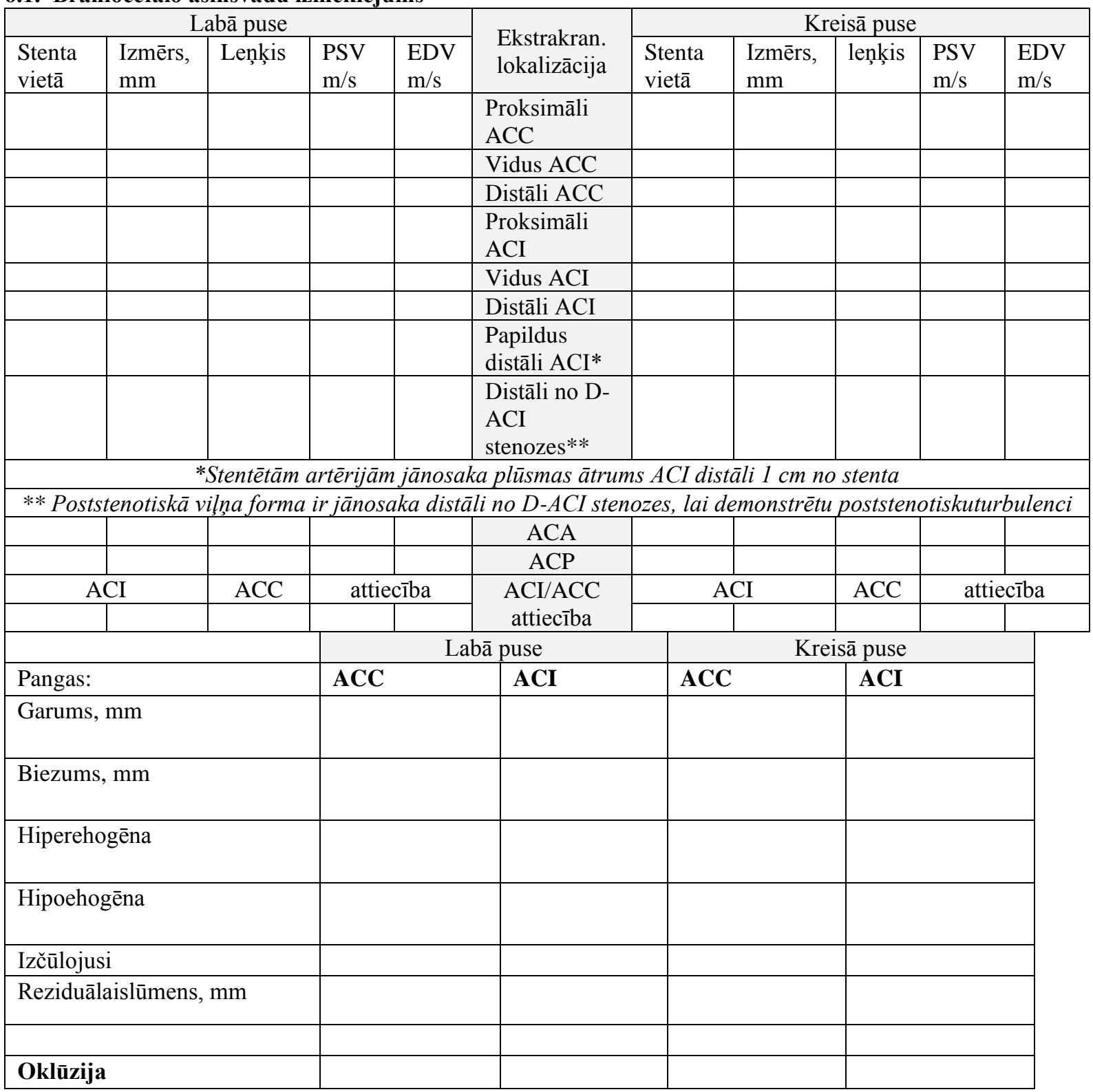

\subsection{CTA}

\begin{tabular}{|l|l|l|}
\hline & \multicolumn{1}{|l|}{ CTA } & Sin (\%) \\
\hline Stenoze ACC & Dx (\%) & \\
\hline Stenoze ACC/ACI (Bulbus) & & \\
\hline Stenoze ACI intrakraniāli (+ segments) & & \\
\hline Stenoze ACI ekstrakraniāli & & \\
\hline Panga ACC & & \\
\hline Panga ACI & & \\
\hline Oklūzija ACC & & \\
\hline Oklūzija ACI & & \\
\hline
\end{tabular}


7. Cerebrovaskulārais notikums

\begin{tabular}{|l|l|l|}
\hline & $\begin{array}{l}\text { Simptomātisks } \\
\text { (ir bijis cerebrovaskulārais notikums } \\
\text { klīniski vai radiologiski) }\end{array}$ & $\begin{array}{l}\text { Asimptomātisks } \\
\text { (nav bijis cerebrovaskulārais notikums, ir } \\
\text { tikai nozīmīga miega artērijas stenoze) }\end{array}$ \\
\hline ACM dx & & \\
\hline ACM sin & & \\
\hline ACA dx & & \\
\hline ACA sin & & \\
\hline $\begin{array}{l}\text { Citur } \\
\text { (bazālie } \\
\text { kodoli) }\end{array}$ & & \\
\hline
\end{tabular}

\section{Pielietotā ārstēšanas metode}
8.1.ENDARTEREKTOMIJA:
a) jā
b) nē

Datums, kad veikta endarterektomija:

Ja simptomātiska stenoze, tad kurā dienā pēc CI/TIL tiek uzsākta MEA:

\begin{tabular}{|l|l|l|}
\hline & Dx & Sin \\
\hline 1. ACC & & \\
\hline 2. ACC/ACI (Bulbus) & & \\
\hline 3. ACI ekstrakraniāli & & \\
\hline
\end{tabular}

Operācijas veids: a) konvencionālā ar primāru šuvi c)konvencionālā ar ielāpu b)eversijasOP ilgums:

Komplikācijas, kas radušās perioperatīvā periodā:

8.2. ENDOVAZĀLA ĀRSTĒŠANA: $\quad$ a) jā

\begin{tabular}{|l|l|l|}
\hline Datums: & Dx & Sin \\
\hline 1. ACC & & \\
\hline 3. ACC/ACI (Bulbus) & & \\
\hline 4. ACI ekstrakraniāli (+ segments) & & \\
\hline
\end{tabular}

Datums, kad veikta endovskulāra ārstēšana:

Pielietotā ierīce:

Ilgums

Pielietotie medikamenti:

Anestēzijas veids:

1)Antiagreganti $48 \mathrm{~h}$ pirms stentēšanas: a) aspirīns
2) Procedūras laikā:
a) Heparīns
b)Vazopresori

mg

b) klopidogrels__ mg

Komplikācijas, kas radušās perioperatīvā periodā:

8.3. MEDIKAMENTOZĀ ĀRSTĒ ŠANA (pēc procedūras):

\begin{tabular}{|l|l|l|l|l|l|l|l|}
\hline $\begin{array}{l}\text { Antihipertensīvie } \\
\text { preparāti }\end{array}$ & V1 & V2 & V3 & Antiagreganti & V1 & V2 & V3 \\
\hline nelieto & & & & Nelieto & & & \\
\hline AKE-I & & & & Aspirīns & & & \\
\hline Sartāni & & & & Klopidogrels & & & \\
\hline KKB & & & & Antikoagulanti & & & \\
\hline Beta blokatori & & & & Nelieto & & & \\
\hline Diurētiķi & & & & Warf & & & \\
\hline & & & & JPOAK & & & \\
\hline Hipolipidiz.med. & & & & & & & \\
\hline Nelieto & & & & Hipoglikem.med. & & & \\
\hline Statīni & & & & Nelieto & & & \\
\hline cits & & & & Insulīns & & & \\
\hline Antiaritmiskie & & & & p/o & & & \\
\hline Nelieto & & & & & & & \\
\hline Lieto & & & & & & & \\
\hline
\end{tabular}




\section{6 mēnešus pēc iekḷaušanas pētījumā (V2 laikā)}

Datums:

NIHSS, mRS novērtējums:

NIHSS:

mRS:

Brahiocefālo asinsvadu izmeklējums

\begin{tabular}{|c|c|c|c|c|c|c|c|c|c|c|}
\hline \multicolumn{5}{|c|}{ Labā puse } & \multirow{2}{*}{$\begin{array}{l}\text { Ekstrakran. } \\
\text { lokalizācija }\end{array}$} & \multicolumn{5}{|c|}{ Kreisā puse } \\
\hline $\begin{array}{l}\text { Stenta } \\
\text { vietā }\end{array}$ & $\begin{array}{l}\text { Izmērs, } \\
\text { mm }\end{array}$ & Leņķis & $\begin{array}{l}\mathrm{PSV} \\
\mathrm{m} / \mathrm{s}\end{array}$ & $\begin{array}{l}\mathrm{EDV} \\
\mathrm{m} / \mathrm{s}\end{array}$ & & $\begin{array}{l}\text { Stenta } \\
\text { vietāa }\end{array}$ & $\begin{array}{l}\text { Izmērs, } \\
\text { mm }\end{array}$ & leņķis & $\begin{array}{l}\mathrm{PSV} \\
\mathrm{m} / \mathrm{s}\end{array}$ & $\begin{array}{l}\mathrm{ED} \\
\mathrm{m} / \mathrm{s}\end{array}$ \\
\hline & & & & & $\begin{array}{l}\text { Proksimāli } \\
\text { ACC }\end{array}$ & & & & & \\
\hline & & & & & Vidus ACC & & & & & \\
\hline & & & & & Distāli ACC & & & & & \\
\hline & & & & & $\begin{array}{l}\text { Proksimāli } \\
\text { ACI }\end{array}$ & & & & & \\
\hline & & & & & Vidus ACI & & & & & \\
\hline & & & & & Distāli ACI & & & & & \\
\hline & & & & & $\begin{array}{l}\text { Papildus } \\
\text { distāli ACI* }\end{array}$ & & & & & \\
\hline & & & & & $\begin{array}{l}\text { Distāli no D- } \\
\text { ACI } \\
\text { stenozes** }\end{array}$ & & & & & \\
\hline \multicolumn{11}{|c|}{ *Stentētām artērijām jānosaka plūsmas ātrums ACI distāli $1 \mathrm{~cm}$ no stenta } \\
\hline \multicolumn{11}{|c|}{ ** Poststenotiskā viļ̧a forma ir jānosaka distāli no D-ACI stenozes, lai demonstrētu poststenotiskuturbulenc } \\
\hline & & & & & ACA & & & & & \\
\hline & & & & & $\mathrm{ACP}$ & & & & & \\
\hline \multicolumn{2}{|c|}{$\mathrm{ACI}$} & $\mathrm{ACC}$ & \multicolumn{2}{|c|}{ attiecība } & $\mathrm{ACI} / \mathrm{ACC}$ & \multicolumn{2}{|c|}{ ACI } & $\mathrm{ACC}$ & \multicolumn{2}{|c|}{ attiecība } \\
\hline & & & & & attiecība & & & & & \\
\hline & & & \multicolumn{3}{|c|}{ Labā puse } & \multicolumn{4}{|c|}{ Kreisā puse } & \\
\hline \multicolumn{3}{|c|}{ Pangas: } & \multicolumn{2}{|l|}{$\mathrm{ACC}$} & ACI & \multicolumn{2}{|l|}{$\mathrm{ACC}$} & \multicolumn{3}{|l|}{ ACI } \\
\hline \multicolumn{3}{|c|}{ Garums, mm } & & & & & & & & \\
\hline \multicolumn{3}{|c|}{ Biezums, mm } & & & & & & & & \\
\hline \multicolumn{3}{|c|}{ Hiperehogēna } & & & & & & & & \\
\hline \multicolumn{3}{|c|}{ Hipoehogēna } & & & & & & & & \\
\hline \multicolumn{3}{|c|}{ Izčūlojusi } & & & & & & & & \\
\hline \multicolumn{3}{|c|}{ Reziduālaislūmens, mm } & & & & & & & & \\
\hline Oklūzi & & & & & & & & & & \\
\hline
\end{tabular}

Komplikācijas pēc procedūras:

Lietotie medikamenti: skat tab. 9.3. 
Datums:

NIHSS, mRS novērtējums:

NIHSS:

mRS:

Brahiocefālo asinsvadu izmeklējums

\begin{tabular}{|c|c|c|c|c|c|c|c|c|c|c|}
\hline \multicolumn{5}{|c|}{ Labā puse } & \multirow[b]{2}{*}{$\begin{array}{l}\text { Ekstrakran. } \\
\text { lokalizācija }\end{array}$} & \multicolumn{5}{|c|}{ Kreisā puse } \\
\hline $\begin{array}{l}\text { Stenta } \\
\text { vietā }\end{array}$ & $\begin{array}{l}\text { Izmērs, } \\
\text { mm }\end{array}$ & leņķis & $\begin{array}{l}\mathrm{PSV} \\
\mathrm{m} / \mathrm{s}\end{array}$ & $\begin{array}{l}\mathrm{EDV} \\
\mathrm{m} / \mathrm{s}\end{array}$ & & $\begin{array}{l}\text { Stenta } \\
\text { vietā }\end{array}$ & $\begin{array}{l}\text { Izmērs, } \\
\text { mm }\end{array}$ & lenķis & $\begin{array}{l}\mathrm{PSV} \\
\mathrm{m} / \mathrm{s}\end{array}$ & $\begin{array}{l}\mathrm{EDV} \\
\mathrm{m} / \mathrm{s}\end{array}$ \\
\hline & & & & & $\begin{array}{l}\text { Proksimāli } \\
\text { ACC }\end{array}$ & & & & & \\
\hline & & & & & Vidus ACC & & & & & \\
\hline & & & & & Distāli ACC & & & & & \\
\hline & & & & & $\begin{array}{l}\text { Proksimāli } \\
\text { ACI }\end{array}$ & & & & & \\
\hline & & & & & Vidus ACI & & & & & \\
\hline & & & & & Distāli ACI & & & & & \\
\hline & & & & & $\begin{array}{l}\text { Papildus } \\
\text { distāli ACI* }\end{array}$ & & & & & \\
\hline & & & & & $\begin{array}{l}\text { Distāli no D- } \\
\text { ACI } \\
\text { stenozes** }\end{array}$ & & & & & \\
\hline \multicolumn{11}{|c|}{ *Stentētām artērijām jānosaka plūsmas ātrums ACI distāli $1 \mathrm{~cm}$ no stenta } \\
\hline \multicolumn{11}{|c|}{$\begin{array}{l}\text { ** Poststenotiskā viļna forma ir jānosaka distāli no D-ACI stenozes, lai demonstrētu } \\
\text { poststenotiskuturbulenci }\end{array}$} \\
\hline & & & & & ACA & & & & & \\
\hline & & & & & $\mathrm{ACP}$ & & & & & \\
\hline \multicolumn{2}{|c|}{$\mathrm{ACI}$} & $\mathrm{ACC}$ & \multicolumn{2}{|c|}{ attiecība } & $\mathrm{ACI} / \mathrm{ACC}$ & \multicolumn{2}{|c|}{ ACI } & $\mathrm{ACC}$ & \multicolumn{2}{|c|}{ attiecība } \\
\hline & & & & & attiecība & & & & & \\
\hline
\end{tabular}

\begin{tabular}{|l|l|l|l|l|}
\hline & \multicolumn{2}{|c|}{ Labā puse } & \multicolumn{2}{c|}{ Kreisā puse } \\
\hline Pangas: & ACC & ACI & ACC & ACI \\
\hline Garums, mm & & & & \\
\hline Biezums, mm & & & & \\
\hline Hiperehogēna & & & & \\
\hline Hipoehogēna & & & & \\
\hline Izčūlojusi & & & & \\
\hline $\begin{array}{l}\text { Reziduālaislūmens, } \\
\text { mm }\end{array}$ & & & & \\
\hline Oklūzija & & & & \\
\hline
\end{tabular}

Komplikācijas pēc procedūras:

Lietotie medikamenti: $\underline{\text { skat tab. 9.3. }}$. 
MoCA tests latviešu un krievu valodā (Nasreddine Ziad, 2015)

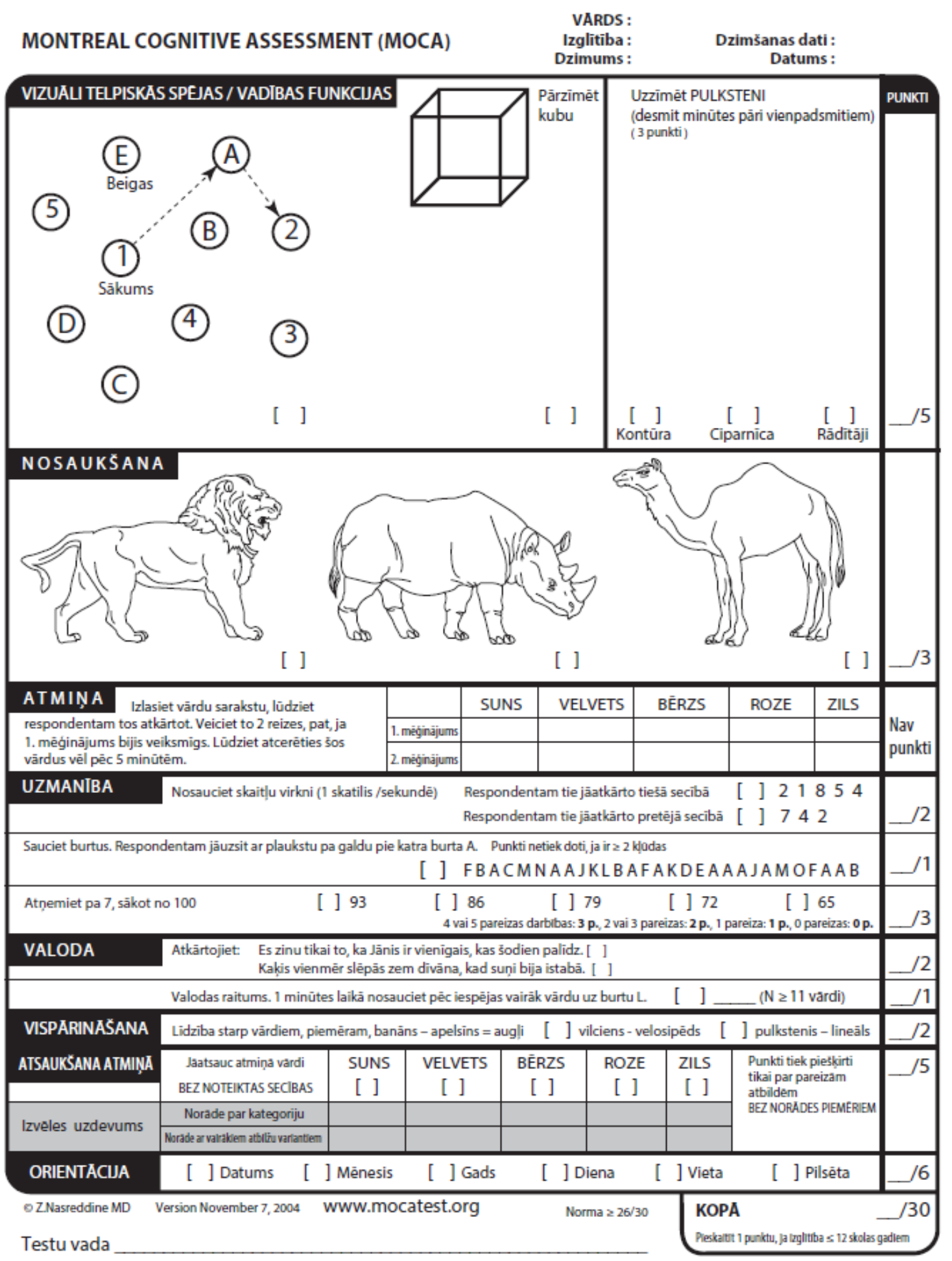




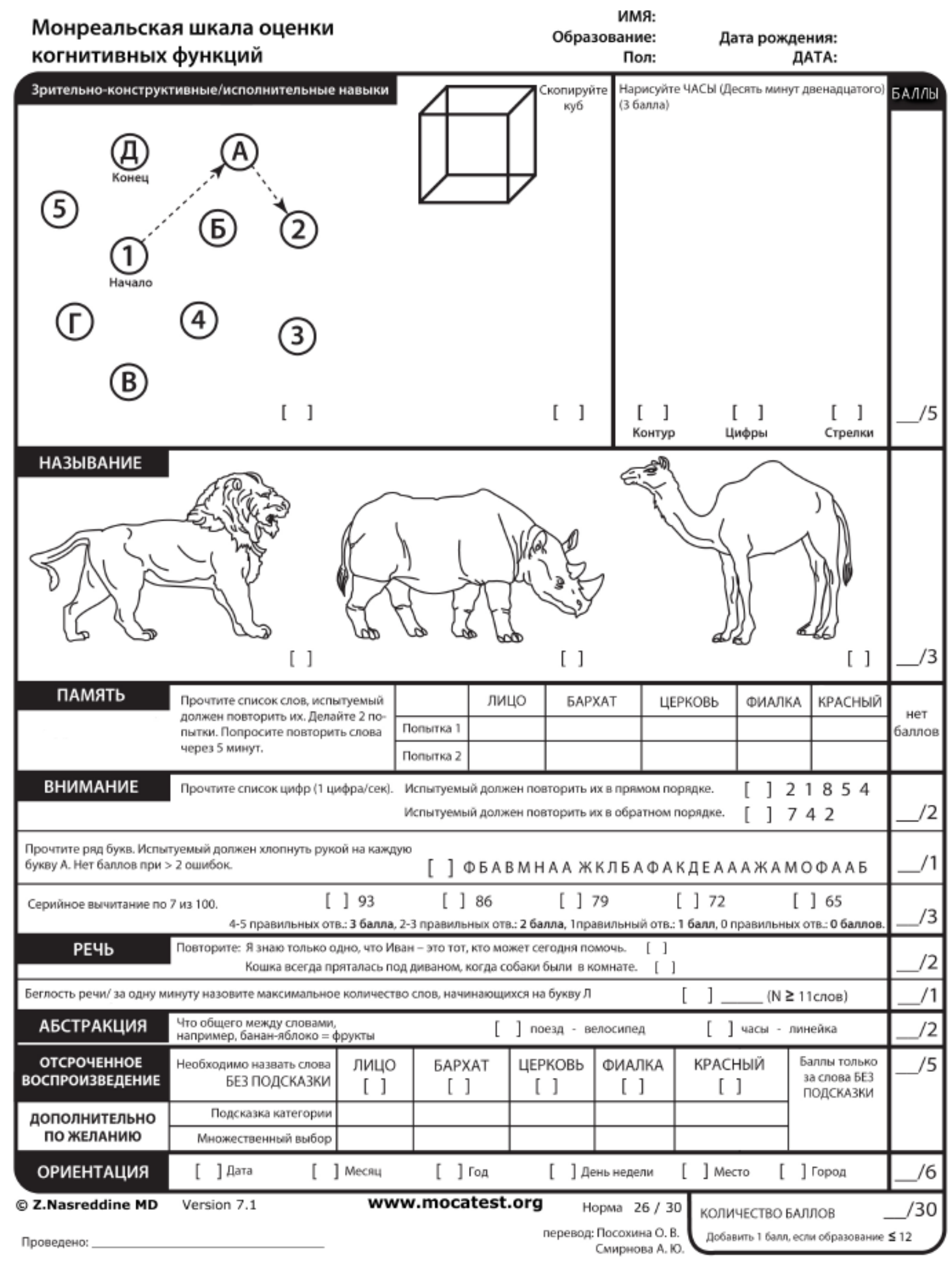


PHQ-9 tests latviešu un krievu valodā (PHQ-9 Instruction Manual, 2015)

\begin{tabular}{|c|c|c|c|c|}
\hline $\begin{array}{l}\text { Cik bieži pēdējo } 2 \text { nedēlu luaikā Jūs ir } \\
\text { apgrūtinājušas kādas no šādām problēmām? } \\
\text { (Atzīmējiet " } \boldsymbol{}^{\prime \prime} \text {, lai norādītu savu } \\
\text { atbildi) }\end{array}$ & Nemaz & $\begin{array}{l}\text { Dažas } \\
\text { dienas }\end{array}$ & $\begin{array}{c}\text { Vairāk } \\
\text { par } \\
\text { nedēlu }\end{array}$ & $\begin{array}{l}\text { Katru vai } \\
\text { gandrīz } \\
\text { katru } \\
\text { dienu }\end{array}$ \\
\hline $\begin{array}{l}\text { 1. Interešu un dzīvesprieka } \\
\text { trūkums }\end{array}$ & 0 & 1 & 2 & 3 \\
\hline $\begin{array}{l}\text { 2.Slikts/nomākts garastāvoklis, nospiestība } \\
\text { vai bezcerības sajūta }\end{array}$ & 0 & 1 & 2 & 3 \\
\hline $\begin{array}{l}\text { 3. Grūtības iemigt, caurs/trausls miegs vai } \\
\text { pārāk ilga gulēšana }\end{array}$ & 0 & 1 & 2 & 3 \\
\hline 4.Nogurums vai enerǵijas trūkums & 0 & 1 & 2 & 3 \\
\hline 5. Pazemināta ēstgriba vai pārēšanās & 0 & 1 & 2 & 3 \\
\hline $\begin{array}{l}\text { 6.Neapmierinātība ar sevi - sajūta, ka esat } \\
\text { neveiksminieks/-ce vai arī esat pievīlis/-usi } \\
\text { savas vai gimenes cerības }\end{array}$ & 0 & 1 & 2 & 3 \\
\hline $\begin{array}{l}\text { 7. Grūtības koncentrēties, piemēram, lasīt } \\
\text { avīzi vai skatīties TV }\end{array}$ & 0 & 1 & 2 & 3 \\
\hline $\begin{array}{l}\text { 8. Kustības un runa bija tik lēna, ka citi cilvēki to } \\
\text { varēja pamanīt. Vai pretēji - bijāt tik } \\
\text { satraukts/satraukta un rosīgs/rosīga, ka kustību } \\
\text { aktivitāte kḷuva lielāka nekā parasti }\end{array}$ & 0 & 1 & 2 & 3 \\
\hline $\begin{array}{l}\text { 9.Domas, ka labāk būtu nomirt vai kaut kā } \\
\text { ievainot sevi }\end{array}$ & 0 & 1 & 2 & 3 \\
\hline \multicolumn{5}{|l|}{ Vērtējumu skaits } \\
\hline \multicolumn{5}{|l|}{ Summa } \\
\hline \multicolumn{5}{|c|}{$\begin{array}{l}\text { Ja Jūs uz kādu no } 9 \text { apgalvojumiem atbildējāt apstiprinoši, novērtējiet, cik lielas } \\
\text { grūtības Jums radīja darbs, nodarbošanās ar sadzīves lietām vai saskarsme ar } \\
\text { cilvēkiem }\end{array}$} \\
\hline Nedaudz grūti & L̦oti grūt & & Ārkārtī & grūti \\
\hline
\end{tabular}




\begin{tabular}{|c|c|c|c|c|}
\hline $\begin{array}{l}\text { Какчастозапоследние } 2 \\
\text { неделиВасбеспокоилиследующиепроблемы? } \\
\text { (Ставьте " } \mathbf{} \text { ", } \\
\text { чтобытуказатьсвойответ) }\end{array}$ & $\begin{array}{c}\text { Нираз } \\
\mathbf{y}\end{array}$ & $\begin{array}{l}\text { Несколькодн } \\
\text { ей }\end{array}$ & $\begin{array}{l}\text { Более } \\
\text { недел } \\
\text { и }\end{array}$ & $\begin{array}{c}\text { Каждыйилипо } \\
\text { чти } \\
\text { каждый } \\
\text { день }\end{array}$ \\
\hline 1.Небыложеланияничегоделать & 0 & 1 & 2 & 3 \\
\hline $\begin{array}{l}\text { 2.Плохоенастроение, } \\
\text { подавленностьиличувствобезнадежности }\end{array}$ & 0 & 1 & 2 & 3 \\
\hline $\begin{array}{l}\text { 3.Вамбылотруднозаснуть, у } \\
\text { Васбылпрерывистыйсон,илиВыслишкоммно } \\
\text { госпали }\end{array}$ & 0 & 1 & 2 & 3 \\
\hline 4.Чувствоусталостиилиобессиленности & 0 & 1 & 2 & 3 \\
\hline 5.Пониженныйилиповышенныйаппетит & 0 & 1 & 2 & 3 \\
\hline $\begin{array}{l}\text { 6.Недовольствособой, } \\
\text { считалисебянеудачником (-цей), были в } \\
\text { себеразочарованы, мысли о том, } \\
\text { чтоподвелисвоюсемью }\end{array}$ & 0 & 1 & 2 & 3 \\
\hline $\begin{array}{l}\text { 7.Трудноконцентрироватьсяначем-либо, } \\
\text { например, } \\
\text { начтениигазетилипросмотретелепередач }\end{array}$ & 0 & 1 & 2 & 3 \\
\hline $\begin{array}{l}\text { 8.Вашидвижения и речьбылизамедлены, } \\
\text { чтобылозаметнодляокружающих, } \\
\text { илиВыбыливзволнованы и суетливы, а } \\
\text { движения - намногоактивнее, чемобычно }\end{array}$ & 0 & 1 & 2 & 3 \\
\hline $\begin{array}{l}\text { 9.Мысли о самоубийствеили о } \\
\text { нанесениисебекакого-нибудьдругоговреда }\end{array}$ & 0 & 1 & 2 & 3 \\
\hline \multicolumn{5}{|l|}{ Числооценок } \\
\hline Сумма & & & & \\
\hline
\end{tabular}

ЕслиВыположительноответилинакакие-нибудьпункты, тооцените, насколькотрудноВамбылоработать, заниматьсядомашнимиделамиилиобщаться с людьмииз-заэтих

проблем?

\begin{tabular}{|l|c|c|c|}
\hline Вообщенебылотрудностей & Былонемноготрудно & Трудно & Оченьтрудно \\
\hline
\end{tabular}


SF-36v2 anketa latviešu un krievu valodā

\section{Jūsu veselībaun pašsajūta}

Šì aptauja ir par to, kā Jūs vērtējat savu veselību.Šĩ informācija palīdzēs sekot tam, kā Jūs jūtaties un cik labi Jūs spējat veikt savas ikdienas aktivitātes.Pateicamies par anketas aizpildī̌̌anu!

Katram sekojošajam jautājumam, lūdzu ievelciet krustiṇu $\bigotimes$ tajā kvadrātā, kas vislabāk raksturotu Jūsu atbildi.

1. Kā Jūs savu veselību kopumā vērtējat:

$\square_{1}^{\text {Lieliska }}$

2. Kā Jūs kopumā novērtētu savu pašreizējo veselības stāvokli salīdzinājumā ar stāvokli gadu iepriekšs?

$\begin{array}{|ccccc|}\begin{array}{c}\text { Daudz } \\ \text { labāka tagad } \\ \text { nekā pirms } \\ \text { gada }\end{array} & \begin{array}{c}\text { Nedaudz } \\ \text { labāka tagad } \\ \text { nekā pirms } \\ \text { gada }\end{array} & \begin{array}{c}\text { Gandrīz } \\ \text { tāda pati } \\ \text { kā pirms } \\ \text { gada }\end{array} & \begin{array}{c}\text { Nedaudz } \\ \text { sliktāka tagad } \\ \text { nekā pirms } \\ \text { gada }\end{array} & \begin{array}{c}\text { Daudz sliktāka } \\ \text { tagad nekāa } \\ \text { pirms gada }\end{array} \\ \square_{1} & \square_{2} & \square_{3} & \square_{4} & \square_{5}\end{array}$


3. Nākamie jautājumi ir par aktivitātēm, kuras Jūs, iespējams, veicat ikdienā.Vaijūsu pašreizējā veselība Jūs ierobežo šajāsaktivitātēs? Jajāa, tad cik lielā mērā?

\begin{tabular}{ccc}
\hline Jā, loti & Jā, mazliet & Nē, nemaz \\
ierobežo & ierobežo & neierobežo
\end{tabular}

a Energiskas aktivitātes, tādas kā skriešana, smagu priekšmetu celšana, piedalīšanāsaktīvos sporta veidos

b Mērenas aktivitātes, tādas kā galda pārbīdīšana, putekḷu sūcēja stumšana, braukšana ar riteni vai peldēšana

c Pārtikas preču celšana vai nešana

d Uzkāpšana pa kāpnēm vairākus stāvus.
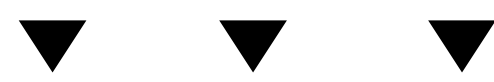

Uzkāpšana pa kāpnēm vienu stāvu

f Noliekšanās, nomešanās uz ceḷiem vai saliekšanās uz priekšu Staigāšana vairāk nekā vienu kilometru

h Staigāšana vairākus simtus metru

i Staigāšana 100 metrus

j Pašam nomazgāties vai apgeērbties

4. Cik bieži pēdējo 4 nedẹlu laikā Jums ir bijušas kādas no šīm problēmām darbā vai citās ikdienas aktivitātēs savas fiziskās veselības dẹẹ??

a Samazinājies laiks, ko Jūs pavadat darbā vai citās aktivitātēs

$\begin{array}{ccccc}\begin{array}{c}\text { Visu } \\ \text { laiku }\end{array} & \begin{array}{c}\text { Lielāko daļu } \\ \text { laika }\end{array} & \begin{array}{c}\text { Reizi pa } \\ \text { reizei }\end{array} & \begin{array}{c}\text { Retu } \\ \text { reizi }\end{array} & \text { Nekad } \\ & & & \end{array}$

Padarījāt mazāk nekā Jūs vēlējāties.

Bijāt ierobežots(-a) veicot kādusdarba pienākumus vai citās aktivitātēs

d Bija grūtības, paveicot darbu vai citas aktivitātes (piemēram, tas prasīja lielāku piepūli).

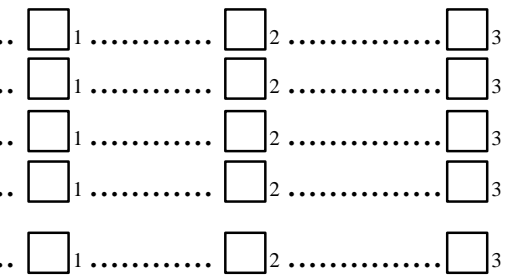


5. Cik bieži pēdēio 4 nedēlu laikā Jums ir bijušas kādas no šīm problēmām darbā vai citās ikdienas aktivitātēs emocionālu problēmu (tādu kā nomāktības vai satraukuma) dēḷ?

a Samazinājies laiks, ko Jūs pavadat darbā vai citās aktivitātēs

\begin{tabular}{|ccccc|}
\hline $\begin{array}{c}\text { Visu } \\
\text { laiku }\end{array}$ & $\begin{array}{c}\text { Lielāko daḷu } \\
\text { laika }\end{array}$ & $\begin{array}{c}\text { Reizi pa } \\
\text { reizei }\end{array}$ & $\begin{array}{c}\text { Retu } \\
\text { reizi }\end{array}$ & Nekad \\
\hline & $\nabla$ & $\nabla$ & $\nabla$ &
\end{tabular}

b $\quad$ Padarìjāt mazāk nekā Jūs vēlējāties

c Veicāt darbu vai citas aktivitātes mazāk rūpīgi nekā parasti

6. Cik lielā mērā pēdējo 4 nedēlu laikā Jūsu fiziskā veselība vai emocionālās problēmas ir traucējušas ierasto sabiedrisko dzīvi ar ğimeni, draugiem, kaimiņiem vai kādu interešu grupu?

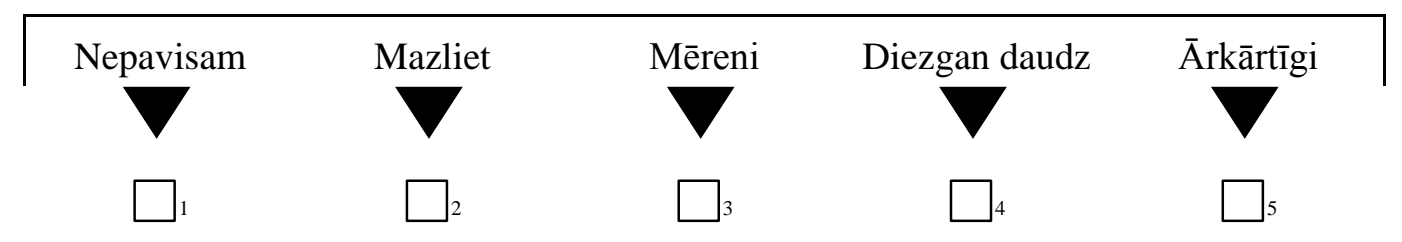

7. Cik izteiktas kermeniskas sāpes Jums ir bijušas pēdējo 4 nedēlu laikā?

\begin{tabular}{|lccccc|}
\hline Nemaz & $\begin{array}{c}\text { Pavisam } \\
\text { vieglas }\end{array}$ & Vieglas & Mērenas & Stipras & Loti stipras \\
$\square_{1}$ & $\square_{2}$ & $\square_{3}$ & $\square_{4}$ & $\square_{5}$ & $\square_{6}$
\end{tabular}

8. Cik lielā mērā pēdējo 4 nedēlu laikā sāpes Jums ir traucējušas veikt ierastos ikdienas darbus (gan darbu ārpus mājas, gan mājas pienākumus)?

\begin{tabular}{|c|c|c|c|c|}
\hline Nepavisam & Mazliet & Mēreni & Diezgan daudz & Ārkārtīgi \\
\hline
\end{tabular}


9. Š̉ie jautājumi ir par to, kā Jūs jutāties un kā Jums klājās pēdējo 4 nedēlu laikā. Katram jautājumam lūdzu izvēlieties vienu atbildi, kas ir vistuvākā tam, kā Jūs jutāties. Cik bieži pēdējo 4 nedệ̣u laikā...

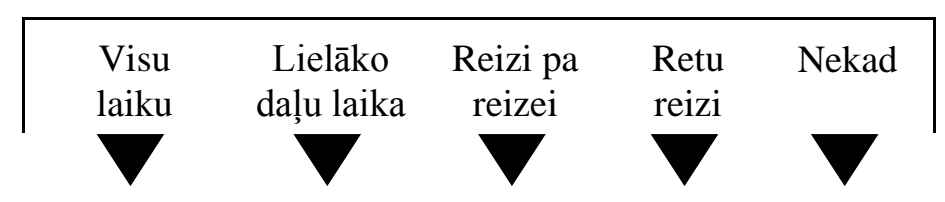

a Vai Jūs esat juties(-usies)

dzīvespriecīgs(-a)?

b Jūs esat bijis(-usi) ḷoti nervozs(-a)?

c Jūs jutāties tik bezcerīgi nomākts(-a), ka nekas Jūs nevarēja uzmundrināt?

d Jūs esat juties(-usies) rāms(-a)

un mierīgs(-a)? ...............................................

(1)

Jums ir bijis daudz energijas?......

f Jūs esat juties(-usies)

g Jūs jutāties izsmelts(-a)?.................... $\square_{1} \ldots \ldots \ldots \ldots . . \square_{2} \ldots \ldots \ldots \ldots . \square_{3} \ldots \ldots \ldots . \square_{4} \ldots \ldots . . \square_{5}$

h Jūs bijāt laimīgs(-a)? ......................... $\square_{1} \ldots \ldots \ldots \ldots . . \square_{2} \ldots \ldots \ldots \ldots . . \square_{3} \ldots \ldots \ldots . . \square_{4} \ldots \ldots \ldots . \square$,

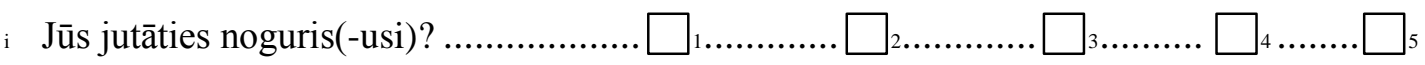

10. Cik bieži pēdējo 4 nedẹlu laikā Jūsu fiziskā veselība vai emocionālās problēmas ir traucējušas Jūsu sabiedriskajā dzīvē - apciemojot draugus, radus, utt?

\begin{tabular}{|lcccc|}
\hline $\begin{array}{l}\text { Visu } \\
\text { laiku }\end{array}$ & $\begin{array}{c}\text { Lielāko daļu } \\
\text { laika }\end{array}$ & Reizi pa reizei & $\begin{array}{l}\text { Retu } \\
\text { reizi }\end{array}$ & Nekad \\
$\square_{1}$ & $\square_{2}$ & $\square_{3}$ & $\square_{4}$ & $\square_{5}$
\end{tabular}


11. Cik PATIESS vai APLAMS ir katrs no sekojošiem apgalvojumiem priekš Jums?

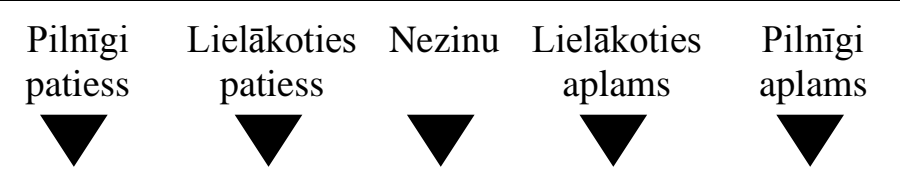

a Liekas, ka es saslimstu nedaudz vieglāk nekā citi cilvēki................... $\square_{1} \ldots \ldots \ldots \ldots . \square_{2} \ldots \ldots \ldots . \square_{3} \ldots \ldots \ldots . \square_{4} \ldots \ldots \ldots \ldots . \square_{5}$

b Es esmu tikpat vesels(-a) kā ikviens, ko pazīstu

c Es sagaidu, ka mana veselība kḷūs sliktāka

d Mana veselība ir lieliska.

Pateicamies par Jūsu atbildēm! 


\section{Ваше здоровье и благополучие}

Эта анкета содержит вопросы, касающиеся Ваших взглядов на своё здоровье. Предоставленная информация поможет следить за тем, как Вы себя чувствуете и насколько хорошо справляетесь со своими обычными нагрузками. Благодарим Вас за ответы на вопросы анкеты!

Для каждого из следующих вопросов поставьте $\bigotimes$ в одном из квадратов, наиболее соответствующем Вашему ответу.

1. В целом, Вы оценили бы состояние Вашего здоровья как:

\begin{tabular}{|c|c|c|c|c|}
\hline Отличное & $\begin{array}{c}\text { Очень } \\
\text { хорошее }\end{array}$ & Хорошее & Посредственное & Плохое \\
\hline
\end{tabular}

2. Как бы Вы в целом оценили своё здоровье сейчас по сравнению с тем, что было год назад?

$\begin{array}{ccccc}\begin{array}{c}\text { Значительно } \\ \text { лучше, чем } \\ \text { год назад }\end{array} & \begin{array}{c}\text { Несколько } \\ \text { лучше чем год }\end{array} & \begin{array}{c}\text { Примерно такое } \\ \text { же, как год }\end{array} & \begin{array}{c}\text { Несколько } \\ \text { хуже, чем год }\end{array} & \begin{array}{c}\text { Гораздо } \\ \text { хуже, чем } \\ \text { год назад }\end{array} \\ \square_{1} & \square_{2} & \square_{3} & \square_{5} & \text { назад }\end{array}$


3. Следующие вопросы касаются действий, которые Вам иногда приходится выполнять в течение обычного дня. Ограничивает ли Вас состояние Вашего здоровья в настоящее время в выполнении перечисленных ниже физических нагрузок? Если да, то в какой степени?

a Тяжелые физические нагрузки, такие как бег, поднятие тяжестей, занятие силовыми видами спорта.

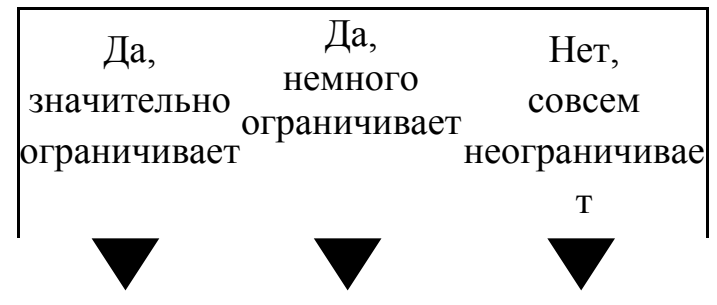

b У меренные физические нагрузки, такие как передвинуть стол, толкать пылесос, собирать грибы или ягоды, ездить на велосипеде

c Поднять и нести сумку с продуктами.<smiles>C1CCC1</smiles>
$\square$. $\square 3$

Подняться пешком по лестнице на несколько пролётов

е Подняться пешком по лестнице на один пролёт.

f Наклониться, встать на колени, присесть на корточки .

g Пройти расстояние более одного километра<smiles>C1CCCC1</smiles>

h Пройти несколько сотен метров

i Пройти сто метров

Самостоятельно вымыться, одеться 
4. Как часто за последние 4 недели Вы испытывали любые из перечисленных ниже затруднений в работе или другой повседневной деятельности из-за Вашего физического состояния?

a Пришлось сократить

\begin{tabular}{|ccccc|}
\hline $\begin{array}{c}\text { Всё } \\
\text { время }\end{array}$ & $\begin{array}{c}\text { Большую } \\
\text { часть } \\
\text { времени }\end{array}$ & Иногда & Редко & Ниразу \\
& & $\nabla$ & &
\end{tabular}
количество времени, затрачиваемого на работу или другие дела.

b Выполняли меньше, чем хотели

с Были ограничены в выполнении какого-либо определённого вида работы или другой деятельности.....

д Были трудности при выполнении своей работы или других дел (например, они потребовали дополнительных усилий)<smiles>C1CCC1</smiles><smiles>C1CCC1</smiles><smiles>C1CCC1</smiles><smiles>[CH]1CC[C@@H]1C1C2CCC21</smiles>

5. Как часто за последние 4 недели Вы испытывали любые из перечисленных ниже затруднений в работе или другой повседневной деятельности из-за Вашего эмоционального состояния (например, депрессии или беспокойства)?

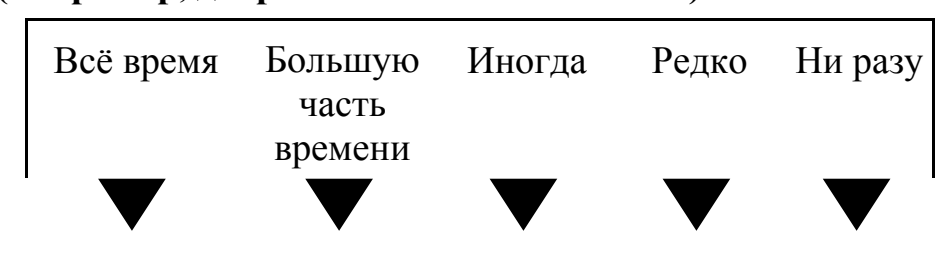

а Пришлось сократить количество времени, затрачиваемого на работу или другие дела.<smiles>C1CC2CCC12</smiles><smiles>C1CC2CC12</smiles><smiles>C1CC2CC12</smiles>

b Выполняли меньше, чем хотели<smiles>C1CCCC1</smiles><smiles>C1CC2CCC12</smiles><smiles>C1CC2CC12</smiles>

c Выполняли свою работу или другие дела менее аккуратно, чем обычно 
6. Насколько Ваше физическое или эмоциональное состояние в течение последних 4 недель мешало Вам проводить время с семьёй, друзьями, соседями или в коллективе?

\begin{tabular}{lcccc|}
$\begin{array}{c}\text { Совсем не } \\
\text { мешало }\end{array}$ & Немного & У меренно & Сильно & $\begin{array}{c}\text { Очень } \\
\text { сильно }\end{array}$ \\
$\square_{1}$ & $\square_{2}$ & $\square_{3}$ & $\square_{4}$ & $\square_{5}$
\end{tabular}

7. Насколько сильную физическую боль Вы испытывали в течение последних 4 недель?

\begin{tabular}{|cccccc|}
\hline $\begin{array}{c}\text { Совсем не } \\
\text { испытывал(а) }\end{array}$ & $\begin{array}{c}\text { Очень } \\
\text { слабую }\end{array}$ & Слабую & Умеренную & $\begin{array}{c}\text { Сильную } \\
\begin{array}{c}\text { Очень } \\
\text { сильную }\end{array}\end{array}$ & $\square_{1}$ \\
$\square_{2}$ & $\square_{3}$ & $\square_{4}$ & $\square_{5}$ & $\square_{6}$
\end{tabular}

8. В какой степени боль в течение последних 4 недель мешала Вам заниматься Вашей обычной работой (включая работу вне дома и по дому)?

\begin{tabular}{|lcccc|}
\hline $\begin{array}{c}\text { Совсем не } \\
\text { мешала }\end{array}$ & Немного & Умеренно & Сильно & Очень сильно \\
$\square_{1}$ & $\square_{2}$ & $\square_{3}$ & $\square_{4}$ & $\square$
\end{tabular}


9. Следующие вопросы касаются того, как Вы себя чувствовали и каким было Ваше настроение в течение последних 4 недель. Пожалуйста, на каждый вопрос дайте один ответ, который наиболее соответствует Вашим ощущениям. Как часто в течение последних 4 недель...

\begin{tabular}{|c|c|c|c|c|}
\hline Всё время & $\begin{array}{c}\text { Большую } \\
\text { часть } \\
\text { времени }\end{array}$ & Иногда & Редко & Ниразу \\
\hline
\end{tabular}

а Вы чувствовали себя

бодрым(-ой)?

ь Вы сильно нервничали?

c Вы чувствовали себя таким(-ой) подавленным(-ой), что ничто немогло Вас взбодрить?.

д Вы чувствовали себя спокойным(-ой) и умиротворённым(-ой)?<smiles>C1CC(C2CCC(C3CCC3)C2)C1</smiles>

• Вы чувствовали себя полным(-ой) сил и энергии?

f Вы ощущали упадок духа или депрессию?

g Вы чувствовали себя измученным (-ой)?<smiles>C1CC(C2C3CCC2C3)C1</smiles><smiles>[CH]1CCC[C@@H]1C1C2CCC1C2</smiles>

Вы чувствовали себя счастливым(-ой)?

Вы чувствовали себя уставшим(-ей)?

10. Как часто за последние 4 недели Ваше физическое или эмоциональное состояние мешало Вам активно общаться с людьми (навещать друзей, родственников и т.п.)?

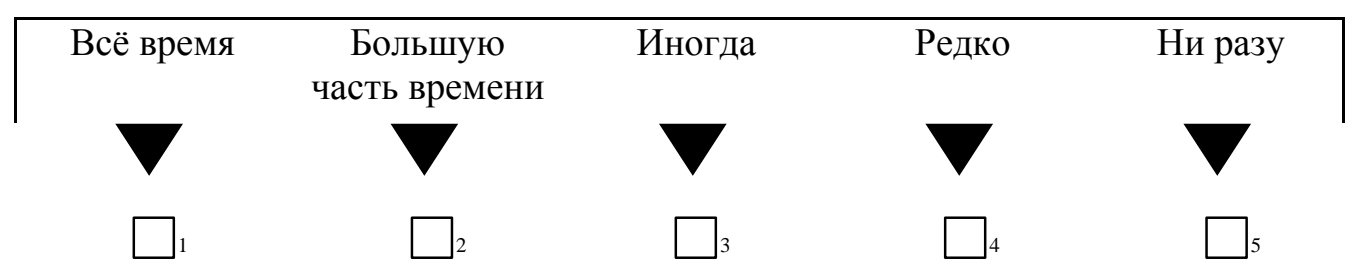


11. Насколько ВЕРНО или НЕВЕРНО представляется по отношению к Вам каждое из нижеперечисленных утверждений?

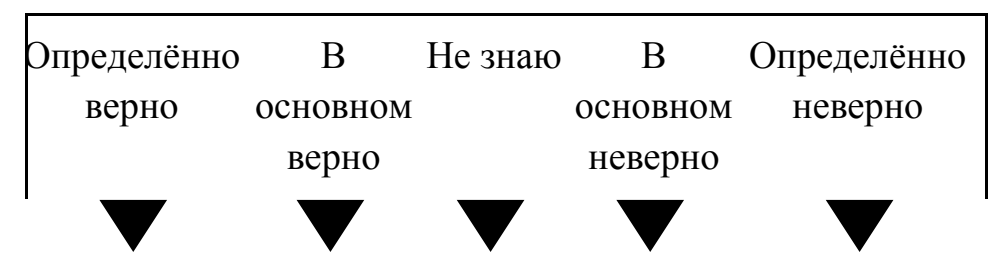

а Мнекажется, что я более склонен(-а) к болезням, чемдругие

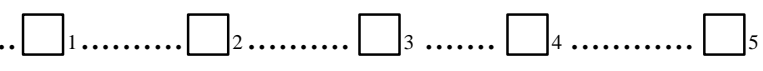

ь Моёздоровьенехуже, чем у большинствамоихзнакомых $\square$ $\square_{2}$. $\square_{3} \ldots \ldots . . \square_{4} \ldots \ldots \ldots \ldots . \square_{5}$

с Я ожидаю, чтомоёздоровье ухудшится.

d У меняотличноездоровье

Благодарим вас за ответы на вопросы!

Atsauce nohttps://www.optum.com/solutions/life-sciences/answer-research/patientinsights/sf-health-surveys/sf-36v2-health-survey.html (Optum, 2015) 
6. pielikums

Dzīves kvalitātes izmaiņas gada laikā pacientiem, kuriem veica miega artērijas endarterektomiju

\begin{tabular}{|c|c|c|c|c|c|}
\hline MEA+MT & $\begin{array}{c}\mathrm{V} 1 \\
(\mathrm{n}=159)\end{array}$ & $\begin{array}{c}\mathbf{V 2} \\
(\mathrm{n}=132)\end{array}$ & $\begin{array}{c}\mathbf{V 3} \\
(\mathrm{n}=128)\end{array}$ & $\underset{\text { vērtība }}{p}$ & $\begin{array}{c}\text { Efekta } \\
\text { lielums } \\
\eta^{2}\end{array}$ \\
\hline $\begin{array}{l}\text { Fiziskās funkcionēšanas spējas } \\
(\mathrm{PF})\end{array}$ & $66,6(22,4)$ & $66,5(21,3)$ & $65,1(22,8)$ & 0,607 & 0,01 \\
\hline $\begin{array}{l}\text { Fiziskā veselības stāvokjla } \\
\text { ietekme uz darbu un citām } \\
\text { ikdienas aktivitātēm (RP) }\end{array}$ & $55,4(26,7)$ & $53,9(25,2)$ & $54,4(27,4)$ & 0,827 & 0,004 \\
\hline Sāpes (BP) & $60(27)$ & $61,7(27)$ & $61,4(26,8)$ & 0,776 & 0,005 \\
\hline $\begin{array}{l}\text { Vispārējais veselības stāvoklis } \\
\text { (GH) }\end{array}$ & $47,6(17)$ & $47,5(14,2)$ & $45(16,4)$ & 0,102 & 0,045 \\
\hline Vitalitāte (VT) & $56,7(18,6)$ & $57,7(20,7)$ & $57(20,4)$ & 0,84 & 0,003 \\
\hline Sociālā funkcija (SF) & $71,7(25,3)$ & $75,2(24)$ & $75,7(22,9)$ & 0,283 & 0,025 \\
\hline Emocionālais stāvoklis (RE) & $65(27,7)$ & $63(28,2)$ & $65,1(25,9)$ & 0,643 & 0,009 \\
\hline Psihiskā veselība (MH) & $63,5(17,5)$ & $64,4(18,9)$ & $64,2(18,7)$ & 0,85 & 0,003 \\
\hline $\begin{array}{l}\text { Fiziskās veselības vispārējais } \\
\text { stāvoklis (PCS) }\end{array}$ & $44(8,5)$ & $44,1(7,5)$ & $43,5(8,4)$ & 0,543 & 0,012 \\
\hline $\begin{array}{l}\text { Psihiskās veselības vispārējais } \\
\text { stāvoklis (MCS) }\end{array}$ & $45,5(10,1)$ & $45,9(10,2)$ & $46,3(9,9)$ & 0,695 & 0,007 \\
\hline
\end{tabular}


7. pielikums

Dz̄̄ves kvalitātes izmaiņas gada laikā pacientiem, kuriem veica miega artērijas angioplastiju ar stentēšanu

\begin{tabular}{|c|c|c|c|c|c|}
\hline PTA+MT & $\begin{array}{c}\text { V1 } \\
(\mathbf{n}=29)\end{array}$ & $\begin{array}{c}\text { V2 } \\
(\mathrm{n}=27)\end{array}$ & $\begin{array}{c}V 3 \\
(n=25)\end{array}$ & $p$ vērtība & $\begin{array}{c}\text { Efekta } \\
\text { lielums } \\
\eta^{2}\end{array}$ \\
\hline $\begin{array}{l}\text { Fiziskās funkcionēšanas spējas } \\
\text { (PF) }\end{array}$ & $53,4(23)$ & $51,6(25,6)$ & $49(23,8)$ & 0,579 & 0,062 \\
\hline $\begin{array}{l}\text { Fiziskā veselības stāvokḷa } \\
\text { ietekme uz darbu un citām } \\
\text { ikdienas aktivitātēm (RP) }\end{array}$ & $47,7(25,7)$ & $46,4(32,8)$ & $38,8(22,4)$ & 0,106 & 0,232 \\
\hline Sāpes (BP) & $48,4(27,2)$ & $54,3(30)$ & $45,2(17,8)$ & $0,028 *$ & $0,343 * *$ \\
\hline $\begin{array}{l}\text { Vispārējais veselības stāvoklis } \\
(\mathrm{GH})\end{array}$ & $44,7(19,5)$ & $42,5(17,8)$ & $42,5(19,5)$ & 0,736 & 0,035 \\
\hline Vitalitāte (VT) & $49,7(20,7)$ & $50,3(23,5)$ & $43,4(22,9)$ & 0,272 & 0,142 \\
\hline Sociālā funkcija (SF) & $65,1(27,2)$ & $70,4(30,4)$ & $57,2(30,4)$ & 0,231 & 0,158 \\
\hline Emocionālais stāvoklis (RE) & $57,9(27,3)$ & $61(34)$ & $55,3(32,1)$ & 0,423 & 0,096 \\
\hline Psihiskā veselība $(\mathrm{MH})$ & $62,6(21,7)$ & $62,6(20,4)$ & $53,4(25,7)$ & 0,132 & 0,212 \\
\hline $\begin{array}{l}\text { Fiziskās veselības vispārējais } \\
\text { stāvoklis (PCS) }\end{array}$ & $39,7(8,3)$ & $39,5(7,8)$ & $38,5(8,5)$ & 0,432 & 0,094 \\
\hline $\begin{array}{l}\text { Psihiskās veselības vispārējais } \\
\text { stāvoklis (MCS) }\end{array}$ & $44,5(10,9)$ & $45,7(11,5)$ & $41(12,3)$ & 0,136 & 0,209 \\
\hline
\end{tabular}


8. pielikums

Dzīves kvalitātes izmaiṇas gada laikā medikamentozās grupas pacientiem

\begin{tabular}{|c|c|c|c|c|c|}
\hline MT & $\begin{array}{c}\mathrm{V} 1 \\
(\mathrm{n}=25)\end{array}$ & $\begin{array}{c}\mathrm{V} 2 \\
(\mathrm{n}=24)\end{array}$ & $\begin{array}{c}\mathrm{V3} \\
(\mathrm{n}=22)\end{array}$ & $p$ vērtība & $\begin{array}{c}\text { Efekta } \\
\text { lielums } \\
\eta^{2} \\
\end{array}$ \\
\hline $\begin{array}{l}\text { Fiziskās funkcionēšanas spējas } \\
\text { (PF) }\end{array}$ & $57(30)$ & $49,3(24,5)$ & $49(20)$ & 0,527 & 0,094 \\
\hline $\begin{array}{l}\text { Fiziskā veselības stāvokḷa } \\
\text { ietekme uz darbu un citām } \\
\text { ikdienas aktivitātēm (RP) }\end{array}$ & $57,1(27,4)$ & $34,6(20,4)$ & $37,5(24,4)$ & $0,039 *$ & $0,392 * *$ \\
\hline Sāpes (BP) & $66,7(26,4)$ & $57,3(25,1)$ & $64,5(24,3)$ & 0,051 & 0,368 \\
\hline $\begin{array}{l}\text { Vispārējais veselības stāvoklis } \\
(\mathrm{GH})\end{array}$ & $47,5(25,6)$ & $40,6(19,3)$ & $39,5(20,6)$ & 0,246 & 0,194 \\
\hline Vitalitāte (VT) & $60,4(20,1)$ & $56,7(16,9)$ & $55(17,2)$ & 0,666 & 0,061 \\
\hline Sociālā funkcija (SF) & $75,8(19,2)$ & $75(20,6)$ & $72,5(20,2)$ & 0,736 & 0,046 \\
\hline Emocionālais stāvoklis (RE) & $71,7(23,1)$ & $62,8(24,8)$ & $50(24,4)$ & $0,039 *$ & 0,039 \\
\hline Psihiskā veselība $(\mathrm{MH})$ & $71,3(15)$ & $62,7(17,8)$ & $61,7(17,2)$ & 0,096 & 0,303 \\
\hline $\begin{array}{l}\text { Fiziskās veselības vispārējais } \\
\text { stāvoklis (PCS) }\end{array}$ & $42,1(8,9)$ & $37,7(8,7)$ & $39,9(8,5)$ & 0,079 & 0,323 \\
\hline $\begin{array}{l}\text { Psihiskās veselības vispārējais } \\
\text { stāvoklis (MCS) }\end{array}$ & $50,1(7,8)$ & $47,9(7,3)$ & $44,5(7,8)$ & $0,045^{*}$ & $0,38 * *$ \\
\hline $\begin{array}{l}* \text { Veicot post-hoc analīzi: RP domēn } \\
p=0,879 ; \text { BP domēnā starp V1 un } \\
\text { RE domēnā starp V1 un V2 } p=0,794 \\
\text { V1 un V2 } p>0,999 ; \text { starp V1 un V } \\
* * \text { efekta lielums } \eta^{2}=0,06 \text { (vidējs) }\end{array}$ & $\begin{array}{l}\operatorname{arp~V1~un~} \\
p=0,89 \\
\operatorname{arp} \mathrm{V} 1 \text { un } \\
=0,135\end{array}$ & $\begin{array}{l}=0,033 \\
\text { rp V1 un } \\
=0,07 ; \mathrm{s}\end{array}$ & $\begin{array}{l}\text { V1 un V } \\
>0,999 ; \\
2 \text { un V3 } p \\
0.052 . \operatorname{Rez}\end{array}$ & $\begin{array}{l}0,043 ; \mathrm{s} \\
\text { V2 un } \\
064 ; \text { MCs } \\
\text { vidèiās }\end{array}$ & $\begin{array}{l}0 \text { V2 un } \\
p=0,0 \\
\text { omēnā st } \\
\text { rtîbas }(\mathrm{S}\end{array}$ \\
\hline
\end{tabular}


9. pielikums

Dzīves kvalitātes salīdzinājums starp grupām pēc 6 mēnešiem (V2 laikā)

\begin{tabular}{|c|c|c|c|c|c|}
\hline & $\begin{array}{c}\text { MEA+MT } \\
(\mathbf{n}=132)\end{array}$ & $\begin{array}{c}\text { PTA+MT } \\
(\mathbf{n}=27)\end{array}$ & $\begin{array}{c}\text { MT } \\
(n=25)\end{array}$ & $p$ vērtība & $\begin{array}{c}\text { Efekta } \\
\text { lielums } \\
\eta^{2} \\
\end{array}$ \\
\hline $\begin{array}{l}\text { Fiziskās funkcionēšanas spējas } \\
\text { (PF) }\end{array}$ & $66,5(21,3)$ & $51,6(25,6)$ & $49,3(24,5)$ & $0,001 *$ & $0,076^{* *}$ \\
\hline $\begin{array}{l}\text { Fiziskā veselības stāvokḷa } \\
\text { ietekme uz darbu un citām } \\
\text { ikdienas aktivitātēm (RP) }\end{array}$ & $53,9(25,2)$ & $46,4(32,8)$ & $34,6(20,4)$ & $0,012 *$ & 0,05 \\
\hline Sāpes (BP) & $61,7(27)$ & $54,3(30)$ & $57,3(25,1)$ & 0,385 & 0,011 \\
\hline $\begin{array}{l}\text { Vispārējais veselības stāvoklis } \\
\text { (GH) }\end{array}$ & $47,5(14,2)$ & $42,5(17,8)$ & $40,6(19,3)$ & 0,106 & 0,026 \\
\hline Vitalitāte (VT) & $57,7(20,7)$ & $50,3(23,5)$ & $56,7(16,9)$ & 0,148 & 0,022 \\
\hline Sociālā funkcija (SF) & $75,2(24)$ & $70,4(30,4)$ & $75(20,6)$ & 0,536 & 0,007 \\
\hline Emocionālais stāvoklis (RE) & $63(28,2)$ & $61(34)$ & $62,8(24,8)$ & 0,612 & 0,006 \\
\hline Psihiskā veselība $(\mathrm{MH})$ & $64,4(18,9)$ & $62,6(20,4)$ & $62,7(17,8)$ & 0,6 & 0,006 \\
\hline $\begin{array}{l}\text { Fiziskās veselības vispārējais } \\
\text { stāvoklis (PCS) }\end{array}$ & $44,1(7,5)$ & $39,5(7,8)$ & $37,7(8,7)$ & $0,005^{*}$ & $0,061 * *$ \\
\hline $\begin{array}{l}\text { Psihiskās veselības vispārējais } \\
\text { stāvoklis (MCS) }\end{array}$ & $45,9(10,2)$ & $45,7(11,5)$ & $47,9(7,3)$ & 0,848 & 0,002 \\
\hline
\end{tabular}


10. pielikums

Dzīves kvalitātes salīdzinājums starp grupām pēc 12 mēnešiem (V3 laikā)

\begin{tabular}{|c|c|c|c|c|c|}
\hline & $\begin{array}{c}\text { MEA+MT } \\
(n=128)\end{array}$ & $\begin{array}{c}\text { PTA+MT } \\
(\mathbf{n}=\mathbf{2 5})\end{array}$ & $\begin{array}{c}\text { MT } \\
(n=22)\end{array}$ & $p$ vērtība & $\begin{array}{c}\text { Efekta } \\
\text { lielums } \\
\eta^{2} \\
\end{array}$ \\
\hline $\begin{array}{l}\text { Fiziskās funkcionēšanas spējas } \\
(\mathrm{PF})\end{array}$ & $65,1(22,8)$ & $49(23,8)$ & $49(20)$ & $0,004 *$ & $0,065^{* *}$ \\
\hline $\begin{array}{l}\text { Fiziskā veselības stāvokḷa } \\
\text { ietekme uz darbu un citām } \\
\text { ikdienas aktivitātēm (RP) }\end{array}$ & $54,4(27,4)$ & $38,8(32,5)$ & $37,5(24,4)$ & $0,016^{*}$ & 0,049 \\
\hline Sāpes (BP) & $61,4(26,8)$ & $45,2(30,9)$ & $64,5(24,3)$ & 0,067 & 0,033 \\
\hline $\begin{array}{l}\text { Vispārējais veselības stāvoklis } \\
\text { (GH) }\end{array}$ & $45(16,4)$ & $42,5(19,5)$ & $39,5(20,6)$ & 0,375 & 0,012 \\
\hline Vitalitāte (VT) & $57(20,4)$ & $43,4(22,9)$ & $55(17,2)$ & $0,014 *$ & 0,051 \\
\hline Sociālā funkcija (SF) & $75,7(22,9)$ & $57,2(30,4)$ & $72,5(20,2)$ & $0,002 *$ & $0,072 * *$ \\
\hline Emocionālais stāvoklis (RE) & $65,1(25,9)$ & $55,3(32,1)$ & $50(24,4)$ & $0,017 *$ & 0,049 \\
\hline Psihiskā veselība $(\mathrm{MH})$ & $64,2(18,7)$ & $53,4(25,7)$ & $61,7(17,2)$ & $0,03 *$ & 0,042 \\
\hline $\begin{array}{l}\text { Fiziskās veselības vispārējais } \\
\text { stāvoklis (PCS) }\end{array}$ & $43,5(8,4)$ & $38,5(8,5)$ & $39,9(8,5)$ & 0,067 & 0,033 \\
\hline $\begin{array}{l}\text { Psihiskās veselības vispārējais } \\
\text { stāvoklis (MCS) }\end{array}$ & $46,3(9,9)$ & $41(12,3)$ & $44,5(7,8)$ & $0,03^{*}$ & 0,049 \\
\hline \multicolumn{6}{|c|}{ 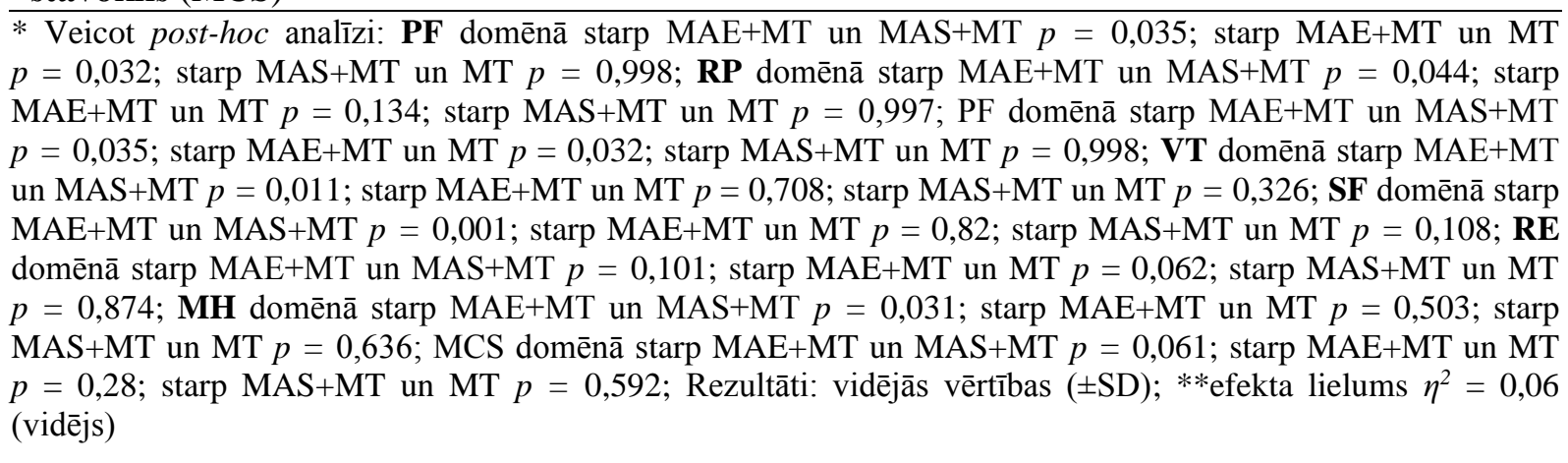 } \\
\hline
\end{tabular}

